\title{
Evaluation of Cone Penetrometer Data for Permeability Correlation at the Savannah River Site
}

by

M. K. Harris

Westinghouse Savannah River Company

Savannah River Site

Aiken, South Carolina 29808

\section{DOE Contract No. DE-AC09-96SR18500}

This paper was prepared in connection with work done under the above contract number with the U.S. Department of Energy. By acceptance of this paper, the publisher and/or recipient acknowledges the U.S. Government's right to retain a nonexclusive, royalty-free license in and to any copyright covering this paper, along with the right to reproduce and to authorize others to reproduce all or part of the copyrighted paper.

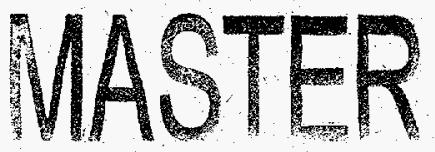




\section{DISCLAIMER}

This report was prepared as an account of work sponsored by an agency of the United States Government. Neither the United States Government nor any agency thereof, nor any of their employees, makes any warranty, express or implied, or assumes any legal liability or responsibility for the accuracy, completeness, or usefulness of any information, apparatus, product, or process disclosed, or represents that its use would not infringe privately owned rights. Reference herein to any specific commercial product, process, or service by trade name, trademark, manufacturer, or otherwise does not necessarily constitute or imply its endorsement, recommendation, or favoring by the United States Government or any agency thereof. The views and opinions of authors expressed herein do not necessarily state or reflect those of the United States Government or any agency thereof.

This report has been reproduced directly from the best available copy.

Available to DOE and DOE contractors from the Office of Scientific and Technical Information, P.O. Box 62, Oak Ridge, TN 37831; prices available from (615) 576-8401.

Available to the public from the National Technical Information Service, U.S. Department of Commerce, 5285 Port Royal Road, Springfield, VA 22161. 


\section{DISCLAIMER}

Portions of this document may be illegible electronic image products. Images are produced from the best available original document. 


\title{
EVALUATION OF CONE PENETROMETER DATA FOR PERMEABILITY CORRELATION AT THE SAVANNAH RIVER SITE
}

\author{
Revision 0 \\ Final
}

\author{
Prepared For \\ WESTINGHOUSE SAVANNAH RIVER COMPANY
}

Prepared By

Parsons Engineering Science, Inc.

1997 Centennial Drive, Building 2, Suite 101

Aiken, South Carolina 29803

and

Applied Research Associates, Inc.

120-A Waterman Road

South Royalton, Vermont 05068

February 1997

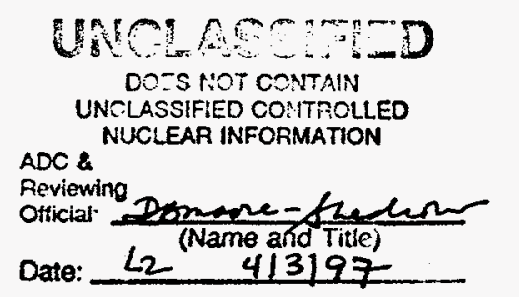




\section{TABLE OF CONTENTS}

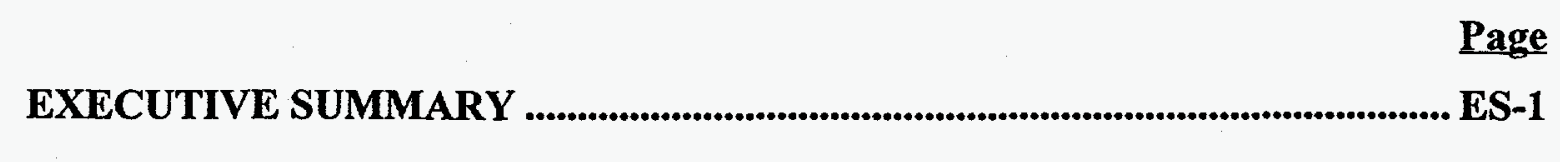

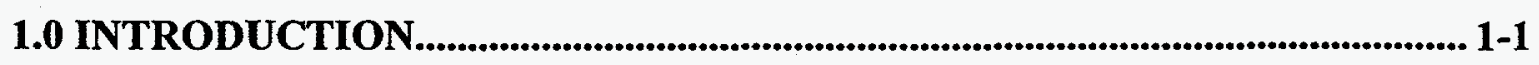

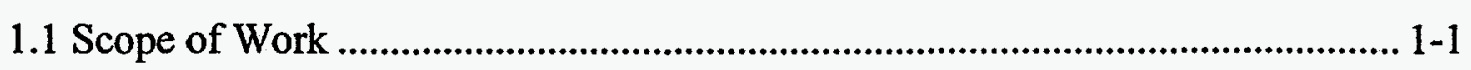

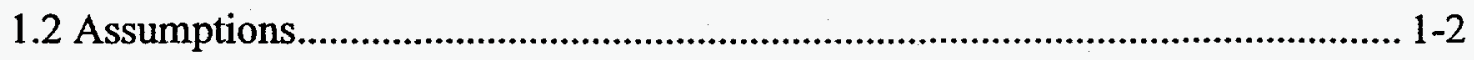

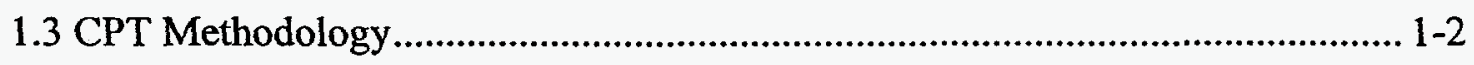

1.3.1 Penetration Resistance Measurements ................................................ 1-4

1.3.2 Piezometric Measurements .......................................................... 1-4

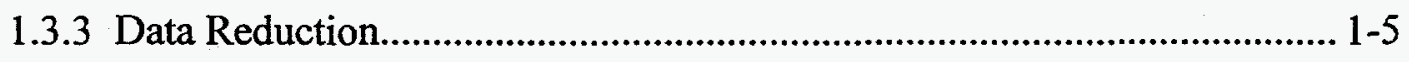

1.3.4 Soil Classification .............................................................................. 1-6

1.3.4.1 Robertson (1990) ................................................................... 1-6

1.3.4.2 Campanella and Robertson (1983)............................................ 1-8

1.3.4.3 Robertson and Campanella (1989) ........................................... 1-8

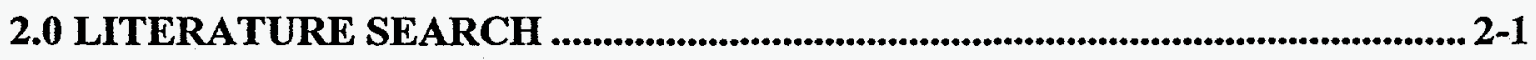

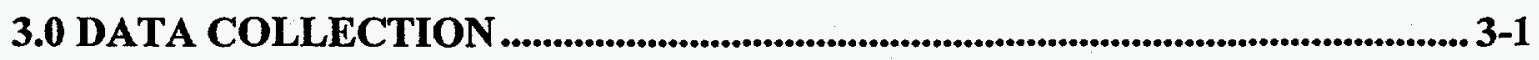

4.0 CPT, LITHOLOGIC CORE, AND GEOPHYSICAL CORRELATIONS........ 4-1

4.1 Soil Classification Correlations .................................................................... 4-1

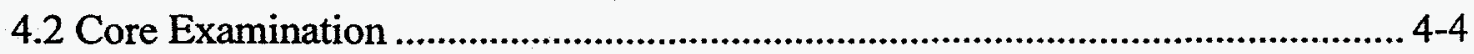

4.3 RPC-1 Detailed Correlation ................................................................... 4-7

4.4 Geophysical Correlation .......................................................................... 4-8

5.0 PERMEABILITY CORRELATIONS AND CURVES.................................5-1

6.0 CONCLUSIONS AND RECOMMENDATIONS............................................... 6-1

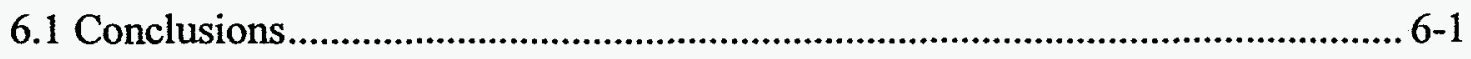

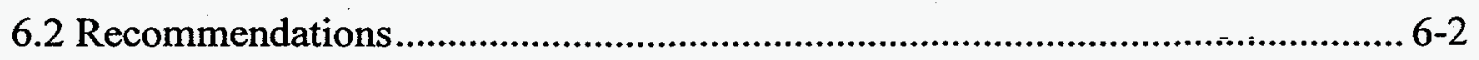

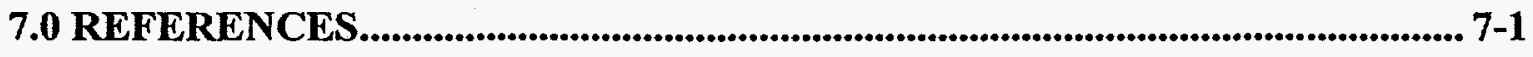




\section{TABLE OF CONTENTS (continued)}

\section{APPENDICES}

A Results of Literature Search

B Core Examination Notes

C Core and Geophysical Logs for BGT-11 and BGT-20 


\section{LIST OF FIGURES}

Page

Figure 1-1 Schematic of ARA's Cone Penetrometer Probe.

Figure 1-2 Proposed Soil Behavior Type Classification Chart Developed by Robertson (1990)

Figure 1-3 Proposed Soil Behavior Type Classification Chart Developed by Campanella and Robertson (1983)

Figure 3-1 Example of an SRS Core Log Sheet $3-3$

Figure 4-1 CPT Soil Classification Chart for Location HBOR-34/HCPT-1 1 Showing Large Amounts of Scatter Corresponding to Depth Regions Identified by Three Lithologic Core Soil Categories

Figure 4-2 Soil Classification Chart Showing Selected Sand Regions Broken Out by Percentage of Mud. 4-10

Figure 4-3 Soil Classification Chart Showing Selected Clayey Sand Regions 4-11

Figure 4-4 Soil Classification Chart Showing Selected Clay Regions 4-12

Figure 4-5 Fugro and Graves Gamma Log Comparison for Location RPC-1 4-13

Figure 4-6 Fugro and Graves Gamma Log Comparison for Location RBW-2 .......... 4-14

Figure 4-7 Fugro and Graves Gamma Log Comparison for Location BGT-3............ 4-15

Figure 4-8 Fugro and Graves Gamma Log Comparison for Location BGT-22......... 4-16

Figure 4-9 Fugro and Graves Gamma Log Comparison for Location OFS-4 ............ 4-17

Figure 4-10 Fugro and Graves Gamma Log Comparison for Location BGT-11 ......... 4-18

Figure 4-11 Fugro and Graves Gamma Log Comparison for Location BGT-20.......... 4-19

Figure 5-1 Anisotropy Analysis of Laboratory Permeability Data. Majority of Data Fall Along Isotropic $45^{\circ}$ Line..

Figure 5-2 Correlation Between Laboratory Measurements of Permeability $(\mathrm{K})$ and Percent Fines. 


\section{LIST OF FIGURES (continued)}

Figure 5-3 Regression Analysis of Hydraulic Conductivity and Normalized Friction Ratio Results from Burial Ground Data....................... 5-8

Figure 5-4 Regression Analysis of Hydraulic Conductivity and Normalized Friction Ratio Results from ARA R-Area Data

Figure 5-5 Regression Analysis of Hydraulic Conductivity and Friction Ratio Results from Fugro R-Area Data

Figure 5-6 Correlation Between Laboratory Measurements of Permeability (K) and Percent Fines for R-Area Data

Figure 5-7 Regression Analysis of Air Hydraulic Conductivity and Friction Ratio Results from Fugro Burial Ground Data.

Figure 5-8 Chart Relating Soil Type to Hydraulic Conductivity (K) with the CPT Soil Classification Number (SCN) Superinposed

Figure 5-9 CPT Data from Location RCH-1 Along with Hydraulic Conductivity Estimates Using Both the Soil Classification Procedure, Friction Ratio Correlation, and Laboratory Hydraulic Conductivity Results

Figure 5-10CPT Data from Location RPC-2 Along with Hydraulic Conductivity Estimates Using Both the Soil Classification Procedure, Friction Ratio Correlation, and Laboratory Hydraulic Conductivity Results.

Figure 5-11 CPT Data from Location RPC-1 Along with Hydraulic Conductivity Estimates Using Both the Soil Classification Procedure, Friction Ratio Correlation, and Laboratory Hydraulic Conductivity Results 


\section{LIST OF TABLES}

Page

Table 3-1 Summary of Data Collected for CPT Correlation.......................................... 3-4

Table 3-2 Summary of Core and CPT Locations ......................................................... 3-6

Table 4-1 Comparison of Geological, Geophysical, and CPT Logs for Location RPC-1

Table 5-1 R-Area Permeabilities with Laboratory, Core, and CPT Data...................... 5-20

Table 5-2 Burial Ground Air Permeabilities with Laboratory, Core, and CPT Data.

Table 5-3 Comparison of Regression Approach and Soil Classification Number Approach for Estimating Hydraulic Conductivity from CPT Data 


\section{LIST OF ACRONYMS, ABBREVIATIONS, AND SYMBOLS}

\begin{tabular}{|c|c|}
\hline a & Net area ratio $\left(A_{N} / A_{T}\right)$ \\
\hline$A_{N}$ & Net area behind the tip not subjected to the pore pressure $\left(1.257 \mathrm{in}^{2}\right)$ \\
\hline $\mathrm{A}_{\mathbf{T}}$ & Projected area of the tip $\left(1.550 \mathrm{in}^{2}\right)$ \\
\hline ANOVA & Analysis of Variance \\
\hline ARA & Applied Research Associates, Inc. \\
\hline ASTM & American Society for Testing and Materials \\
\hline BGT & Burial Ground core locations \\
\hline $\mathbf{B}_{\mathbf{q}}$ & Pore pressure ratio \\
\hline bls & below land surface \\
\hline $\mathrm{cm}$ & centimeter(s) \\
\hline COR & Corrected \\
\hline CPT & Cone Penetrometer Technology \\
\hline CPTU & Cone Penetrometer Technology with pore pressure measurement \\
\hline CPT(U) & $\begin{array}{l}\text { CPT or CPTU in context where there is no need to discriminate between } \\
\text { the two tests }\end{array}$ \\
\hline EB & Burial Ground core locations \\
\hline EC & Electronic conductivity \\
\hline $\mathrm{ft}$ & foot (feet) \\
\hline FR & Friction Ratio \\
\hline $\mathbf{f}_{\mathrm{s}}$ & $\begin{array}{l}\text { Sleeve friction (tsf) [= total frictional force on the sleeve divided by the } \\
\text { sleeve's surface area }\left(23.26 \text { in }^{2}-\text { ARA)] }\right.\end{array}$ \\
\hline $\mathrm{F}_{\mathrm{sn}}$ & Normalized friction ratio \\
\hline HBOR & H-Area core locations \\
\hline HSPT & H-Area core locations \\
\hline HTF & H-Area core locations \\
\hline IDW & Investigation-Derived Waste \\
\hline in & inch(es) \\
\hline $\mathrm{K}$ & Hydraulic conductivity (permeability) \\
\hline $\mathrm{K}_{\mathrm{h}}$ & Horizontal hydraulic conductivity \\
\hline $\mathrm{K}_{\mathrm{v}}$ & Vertical hydraulic conductivity \\
\hline LCO & L-Area core locations \\
\hline m & meter(s) \\
\hline NR & No Recovery \\
\hline OFS & Burial Ground core locations \\
\hline
\end{tabular}




\section{LIST OF ACRONYMS, ABBREVIATIONS, AND SYMBOLS (continued)}

pcf pounds per cubic foot

psf pounds per square foot

$\mathrm{q}_{\mathrm{c}} \quad$ Measured (uncorrected) tip resistance (tsf)

$\mathrm{q}_{\mathrm{t}} \quad$ Corrected tip resistance (tsf)

$Q_{\mathrm{tn}} \quad$ Normalized tip stress (tsf)

RBW R-Area core locations

$\mathrm{RCH} \quad \mathrm{R}$-Area core locations

RPC R-Area core locations

$\sigma_{\mathrm{vo}}$

Total overburden stress (tsf)

$\sigma_{\text {vo }}^{\prime}$

Effective overburden stress (tsf)

SCN Soil Classification Number

SRS Savannah River Site

SWDT Burial Ground core locations

tsf tons per square foot

$\mathrm{u} \quad$ Penetration pore pressure measured behind tip (tsf)

$\mathrm{u}_{0} \quad$ Static pore pressure, determined from the water table elevation (tsf)

UNC Uncorrected

USC University of South Carolina

USCS Unified Soil Classification System

USGS United States Geological Survey

WSRC Westinghouse Savannah River Company 


\section{EXECUTIVE SUMMARY}

This report documents the results of an assessment of cone penetrometer technology (CPT) use at the Savannah River Site (SRS). The study is intended to provide valuable insight into methods of increasing the utility of CPT data for site characterization.

\section{ES.1 Introduction}

CPT is a method of Direct Push technology that involves advancing an instrumented probe (or penetrometer) into the subsurface using a hydraulic ram. A piezometric pressure transducer can be added to the basic CPT penetrometer to simultaneously acquire both geotechnical and hydrogeological data. Piezometric data and soil shear resistance measurements are then simultaneously recorded during penetrometer advancement. These data are transmitted by electric cable to a computer at the surface and used to rapidly, accurately, and economically develop repeatable, continuous, highresolution profiles of in situ soil conditions.

The identification and classification of in situ soil types has become one of the primary applications of CPT. The general procedure for obtaining a soil behavior type or soil classification number (SCN) is to plot the CPT data in Log-Log space and assign an SCN to all data falling within the predetermined boundaries of a soil behavior-type classification chart. The principal soil behavior-type classification charts presently used for CPT testing include those developed by Robertson and by Campanella and Robertson. The primary differences between these charts are adjustments of the raw data for physical factors such as pore water pressure and overburden stress due to gravity.

\section{ES.2 Literature Search}

A literature search was performed to identify recent publications dealing with CPT and CPT-derived soil classifications and permeability. The results of this search are presented in Appendix A. A search of the Internet using the Lycos search engine yielded 36 related articles, while computer searches of the University of South Carolina-Aiken and University of Florida libraries yielded 40 and 80 related references, respectively. 


\section{ES.3 Data Collection}

Over the course of this project, data were compiled from 27 locations at the $R, L$, and $H$ Areas and the Burial Ground Complex at the SRS. These data included CPT profiles, lithologic core descriptions (averaged over $1 \mathrm{ft}$ ), field geologic logs, geophysical logs (natural gamma, resistivity, spontaneous potential, and caliper), laboratory results of grain-size and permeability analyses, SRS location coordinates, surface elevations, and water table elevations.

\section{ES.4 CPT, Lithologic Core, and Geophysical Correlations}

The most commonly used soil behavior-type classification chart for CPT data is that developed by Robertson. Prior to using this chart, the corrected tip stress and the friction ratio are normalized to remove gravity stress effects that occur due to testing at different depths in the soil environment. The normalized data are then plotted in Log-Log space and each data point is assigned an SCN based on its particular location in the chart.

For the SRS data sets provided for this project, SCN values of 5 and 6 correspond to a core classification of sand, SCN values of 3 and 4 correspond to a core description of clayey sand to sandy clay, and values of 2 and 3 correspond to a core description of clay. Based upon these data, there is currently insufficient evidence to justify changing the soiltype boundary curves for SRS soils from those presented in the Robertson chart. However, Robertson's Region 2 should possibly be redefined as "soft clayey soils," in lieu of its original description as "organic soils."

\section{ES.5 Permeability Correlations and Curves}

Two approaches were developed for permeability estimates based on CPT. The "soil classification" approach is based upon the correlation between the SCN and permeability, while the " $F_{\mathrm{sn}}$ regression" approach is based upon a correlation between the normalized friction ratio $\left(\mathrm{F}_{\mathrm{sn}}\right)$ and permeability. Each approach offers reasonable results. However, the soil classification approach overpredicts the permeability of coarse materials (i.e., coarse to gravely sands) while the $F_{s n}$ regression approach underpredicts the permeability of fine materials (i.e., clays and silty clays). A limited statistical analysis indicates that, based upon the limited data set, the $F_{s \mathbf{n}}$ regression approach appears to offer somewhat 
more accurate predictions. Additional data are needed to confirm this correlation over a significantly larger data set and to extend chart boundaries where deemed applicable.

\section{ES.6 Recommendations}

The analyses performed and presented in this report are based upon a series of assumptions and a somewhat limited data set. The most significant recommendation is that additional data be gathered and the analysis be re-evaluated. Directly comparable data are a prerequisite to correctly and consistently correlate CPT, geophysical, and geological logs and, ultimately, to develop a site-specific algorithm to allow CPT to replace some core drilling at the SRS. However, due to the nature of fluvial systems, even a horizontal separation of 5 feet or less can demonstrate significant changes in lithologic facies. Therefore, it is recommended that a statistically significant number of paired CPT-core borings be made across the SRS wherein a 4- to 6-in core is taken within inches of a CPT penetration. Rotasonic core drilling would especially lend itself to such a project, since it yields a relatively undisturbed 5 -in core, produces little waste, and is significantly faster than conventional core drilling techniques.

In addition to the field data, a laboratory study using soils with different fine-grain contents should be prepared and tested using CPT in controlled conditions. Items to be controlled include fine-grain content and horizontal and vertical stress states. From this information, the CPT response to various fine-grain contents and layer interface influences can be determined and evaluated.

The data base of coincident CPT, geophysical, and geological information needs to be expanded to cover all the typical soil materials at the SRS, including both permeable and nonpermeable materials. The types of additional data needed are laboratory grain-size and hydraulic conductivity tests on very specific core sections that are accurately defined in both location and depth. Additional refinement in the core data is needed to verify existing boundaries and improve correlations. To obtain data for additional refinement, grain-size analyses are needed for comparison to CPT data to develop more grain-size classifications for the CPT system. This approach will refine the core descriptions and allow for better soil descriptions. 


\subsection{INTRODUCTION}

This report documents the results of an assessment of cone penetrometer technology (CPT) use at the Savannah River Site (SRS). CPT is a method of direct push technology that involves advancing a measuring probe into the subsurface using a hydraulic ram. The probe consists of a rod with a conical tip and a steel sleeve. Sensors within the tool measure resistance against the tip and frictional stress against the sleeve. The probe also contains a device for measuring pore pressure that can be used to correct for hydrostatic stresses against tip resistance. Several optional measuring devices can be incorporated into the CPT instrument, including resistivity modules and natural gamma ray detectors.

CPT, as well as other Direct Push methods, have been used at the SRS for several years without a comprehensive correlation to the more traditional characterization methods such as wireline coring and geophysical logging. In addition to characterization, CPT may also be used to directly predict soil permeability. Applied Research Associates, Inc. (ARA), under contract to Parsons Engineering Science, Inc. (Parsons), was tasked with evaluating the CPT soil behavior charts used at the SRS and developing a correlation between the CPT measurements and laboratory-determined permeability data. As a part of this effort, the SRS core descriptions were used to evaluate the CPT results.

\subsection{Scope of Work}

The objectives of this study were to develop site-specific CPT correlations to the standard types of characterization data (wireline sediment cores and geophysical log suites) in use at the SRS and to develop a site-specific CPT permeability curve. To complete these objectives the following tasks were required:

1. Complete a literature search on the use of CPT data and methods of correlation.

2. Collect existing CPT, lithologic core, downhole geophysical information, and permeability data at coinciding sample locations from the following SRS areas: R Area, L Area, H Area, and the Burial Ground Complex.

3. Correlate CPT, lithologic core, and geophysical data by direct comparison on a footby-foot basis.

4. Determine the need for an SRS-specific soil classification chart or a modification of the existing Robertson (1990) chart. 
5. Develop a permeability curve using the paired CPT and laboratory hydraulic conductivity data.

6. Make recommendations for improving the accuracy of correlation between CPT and the standard characterization methods.

\section{$1.2 \quad$ Assumptions}

The analysis presented herein is based upon information and data provided by SRS and on several basic assumptions. These assumptions are:

- All CPT locations and corresponding soil borings are located within a $10-\mathrm{ft}$ radius.

- When available water table elevation data conflict with CPT pore pressure profiles, the water table elevations from the pore pressure profiles are used.

- When utilizing CPT data from Fugro Geosciences, Inc. (Fugro), the net area ratio of the CPT cone is used to correct tip stress results for pore pressure effects.

- Where CPT data do not agree with foot-by-foot core descriptions, it may be due to one of the following: (1) core loss occurred during drilling (in subsequent data reports for the same core, the core log is shifted accordingly), (2) the CPT push was performed in a different location than the core, and (3) CPT evaluated different parameters than the core description (i.e., soil behavior characteristics versus grain size, sorting, etc.).

These assumptions should be considered when utilizing the correlations developed herein.

\section{$1.3 \quad$ CPT Methodology}

The CPT test consists of smoothly pushing a small-diameter, instrumented probe (penetrometer) deep into the ground while a computer data acquisition system displays and records the soil response to penetration. Figure 1-1 presents a schematic of the ARA penetrometer equipment. Penetrometer data are used to rapidly, accurately, and economically develop continuous, high-resolution profiles of in situ soil conditions. Performance of CPT is specified by American Society for Testing and Materials (ASTM) Standard D3441. 
The CPT penetrometer is used to measure soil shear resistance to penetration, which acts on the tip and along the sides of the penetrometer. The penetrometer models a driven, foundation pile under plunging failure load conditions.

CPT soil shear resistance measurements are accurate and repeatable, and various geotechnical parameters can be interpreted from CPT shear resistance data. These interpretations may be enhanced by adding additional measuring and sampling devices as those described below:

- A piezometric pressure transducer can be added to the basic CPT penetrometer to simultaneously acquire both geotechnical and hydrogeological data. Tests conducted with this penetrometer are called Piezometric Cone Penetration Tests (CPTU).

- Soil electrical conductivity can also be measured during penetrometer testing (CPTUEC) to allow for the simultaneous acquisition of geotechnical, hydrogeological, and certain geochemical data.

- Penetrometer groundwater and soil samplers can be used during environmental characterization studies.

The CPT(U) (refers to either CPT or CPTU) penetrometer is mounted at the end of a string of sounding rods. A three-axle truck is used to house, transport, and deploy the penetrometer. A hydraulic ram is used to push the penetrometer and rods into the ground at a constant rate of approximately $4 \mathrm{ft}$ per minute. Pressures of up to 2 million pounds per square foot (psf) can be applied to the tip of a penetrometer. Forty-thousand pounds (20 tons) of truck weight and ballast are used to counteract the thrust of the hydraulic ram. Electronic signals from downhole transducers are transmitted by a cable, strung through the sounding rods, to a computer at the surface. A graphical display of measurements is monitored to evaluate test performance; it renders immediate definition of site stratigraphy. The vertical alignment of the hole may be measured with an inclinometer located in the upper end of the probe.

At the end of a test, the penetrometer and sounding rods are withdrawn from the ground. If required, downhole equipment is steam cleaned and decontaminated during retrieval. The open hole left after penetrometer retrieval can be grouted after completion of the test by inserting a tremie pipe to total depth and pumping the grout by pushing "dummy rods" with sacrificial cone tips down the hole and pumping the grout, or by using specialized penetrometers designed to allow grouting upon first retrieval. 
No drilled borehole is required during penetrometer operations because penetrometers are thrust directly into the soil from the ground surface. Site disturbance is minimized since no borehole cuttings or drilling fluids are generated during penetrometer operations. Personnel exposure to possibly contaminated soil during penetrometer operations is significantly less than exposures during drilling and sampling operations. When contaminated soils are encountered, the small-diameter, flush surface penetrometer sounding rods and penetrometers are decontaminated by steam cleaning during retrieval.

\subsubsection{Penetration Resistance Measurements}

The resistance of a soil to penetration is measured on the tip and along the sides of the CPT penetrometer. The following configurations are typical of penetrometers used by Fugro and ARA. The first value of each dimension represents the ASTM (1986) recommended dimensions for CPT cones and friction sleeves. The conical tip of the penetrometer has a 60-degree apex angle, a projected cross-sectional area of generally 10 to $15 \mathrm{~cm}^{2}$ (1.55 to $2.3 \mathrm{in}^{2}$ ), and a diameter of 3.57 to $4.35 \mathrm{~cm}(1.4$ to $1.7 \mathrm{in})$. Measurements taken with the cone tip directly reflect the deep bearing capacity of the penetrated soil. The measurements are termed "cone" or "cone end bearing resistance" $\left(q_{c}\right)$.

The sliding friction between the soil and the advancing steel penetrometer is measured along a cylindrical sleeve mounted just above the conical tip of the penetrometer. The friction sleeve has a surface area of 150 to $200 \mathrm{~cm}^{2}$ (23.2 to $31.0 \mathrm{in}^{2}$ ), a length of 13.4 to $16.5 \mathrm{~cm}$ (5.27 to $6.5 \mathrm{in}$ ), and a diameter of 3.57 to $4.35 \mathrm{~cm}$ (1.4 to $1.7 \mathrm{in}$ ) (the same diameter as the conical tip). Soil friction measured on the sleeve is termed "friction sleeve resistance," or just "friction resistance" $\left(f_{s}\right)$. Loadcells, mounted inside the penetrometer, are used to simultaneously measure the cone-end bearing and friction sleeve resistance. These measurements are typically reported in tons per square foot (tsf).

\subsubsection{Piezometric Measurements}

As mentioned previously, a piezometric pressure transducer can be added to the basic CPT penetrometer to simultaneously acquire both geotechnical and hydrogeological data. It is mounted inside the penetrometer and is used to measure the soil pore water pressure response to penetration. Piezometric data, along with soil shear resistance measurements, are simultaneously recorded during penetrometer advancement. The CPTU piezometric 
measurement has a resolution of about $2.54 \mathrm{~cm} \mathrm{(1} \mathrm{in)} \mathrm{and} \mathrm{an} \mathrm{accuracy} \mathrm{of} \mathrm{about}+/-15 \mathrm{~cm}$ $(0.5 \mathrm{ft})$ of water head pressure.

The intense volumetric distortion of a saturated soil during penetrometer advance generates a localized pore water pressure field around the probe. In soils of high permeability (e.g., clean sands and gravels), these generated pressures dissipate almost instantaneously, so equilibrium water pressures are measured during CPTU. In mediumor low-permeability soils (e.g., dirty sands and fine-grained soils), generated pore water pressures require a significant amount of time to dissipate, so high pore water pressures are measured during CPTU. Atmospheric (zero) pressure is measured during CPTU in unsaturated soils.

The dissipation of generated excess pore water pressures can be recorded as a function of time by pausing in the penetration process; this is termed a "CPTU dissipation test." If the pauses are sufficiently long for all generated pore water pressures to dissipate, a series of potentiometric surface measurements can be obtained in a single CPTU sounding. The rate of dissipation can also be used to estimate horizontal permeability.

\subsubsection{Data Reduction}

CPT(U) test data are monitored by a professional geotechnical engineer or geologist as the soundings are performed. Data are recorded electronically and consist of depth, time, cone-end bearing resistance, friction sleeve resistance, generated pore water pressure, and total load on the penetrometer.

An interpretation of the subsurface can be made during CPT operations using the above information. The CPT cone-end bearing resistance increases exponentially as grain size increases. In addition to measured data, the friction ratio (FR) can be calculated to enhance $\mathrm{CPT}(\mathrm{U})$ interpretation by the following equation:

$$
\begin{aligned}
& \text { friction ratio, } \mathrm{FR} \text { (as a \%): } \\
& \qquad \mathrm{FR}=\mathrm{f}_{\mathrm{s}} / \mathrm{q}_{\mathrm{c}} * 100
\end{aligned}
$$

where:

$$
\begin{aligned}
& \mathrm{f}_{\mathrm{s}}=\text { friction sleeve resistance (in tsf) } \\
& \mathrm{q}_{\mathrm{c}}=\text { measured tip resistance (in tsf) }
\end{aligned}
$$


The proportion of friction sleeve resistance to tip resistance, FR, is related to the fines content of a soil. The FR is generally low in sands and high in clays.

Recorded data are processed for final reporting using an in-house computer system. Prior to final reporting, all data must pass a quality control review. Penetrometer-specific calibration is performed prior to initiating a new series of tests. Additional office reviews help to assure that the digital electronic measurement systems maintain a high level of accuracy throughout a study. Measured data and computed parameters are presented in a graphical sounding log format for each sounding.

\subsubsection{Soil Classification}

The identification and classification of in situ soil types has become one of the primary applications of CPT, as well as one of the most heavily researched (Zhang 1994). The benefits of accurately identifying soils by CPT include faster, less expensive investigations that generate substantially less investigation-derived waste (IDW) than conventional drilling methods. However, many believe that all the charts to date cannot be expected to provide accurate prediction of soil types from a compositional classification and that they can only be used as a guide to a soil classification of behavior type (Douglas and Olsen 1981, Campanella and Robertson 1988).

The general procedure for obtaining a soil behavior type or SCN is to plot the CPT data in Log-Log space and assign an SCN to all data falling within a predetermined boundary. The primary difference between the various soil classification charts is the adjustment of the raw data for physical factors such as pore water pressure and overburden stress due to gravity.

The following subsections address the parameters found in the soil classification charts used by ARA (Robertson 1990) and Fugro (Campanella and Robertson 1983). Section 5 gives a detailed account of the relationship of core and geophysical data to the behavior types identified by CPT.

\subsubsection{Robertson (1990)}

There are two charts in Robertson's soil classification system (Figure 1-2). The first chart is based upon tip resistance $\left(q_{c}\right)$ and friction sleeve resistance $\left(f_{s}\right)$. The second chart 
shows a plot of $q_{c}$ against pore pressure ratio $\left(B_{q}\right)$. For this chart, $q_{c}$ must first be corrected for total cone resistance ( $\left.q_{t}\right)$ by Eq. 2 shown below. Water pressures can act on the exposed surfaces behind the cone tip and on the ends of the friction sleeve. These water forces result in measured $q_{c}$ and $f_{s}$ values that do not represent true total stress resistances of the soil. This error introduced in the measurement can be overcome by correcting the measured $\mathrm{q}_{\mathrm{c}}$ for unequal pore pressure effects using the following relationship (Campanella et al. 1982, Robertson and Campanella 1988):

$$
\mathrm{q}_{\mathrm{t}}=\mathrm{q}_{\mathrm{c}}+\mathrm{u}(1-\mathrm{a})
$$

where:

$$
\begin{aligned}
& \mathrm{q}_{t}=\text { corrected total tip resistance (in tsf) } \\
& \mathrm{u}=\text { pore pressure generated immediately behind the cone tip (tsf) } \\
& \mathrm{a}=\text { net area ratio }\left(\mathrm{A}_{\mathrm{N}} / \mathrm{A}_{\mathrm{T}}\right)
\end{aligned}
$$

The corrected tip resistance is then normalized $\left(Q_{t n}\right)$ to remove the gravity stress effects that occur due to testing at different depths in the soil environment by using the following expression:

$$
\mathrm{Q}_{\mathrm{tn}}=\left(\mathrm{q}_{\mathrm{t}}-\sigma_{\mathrm{vo}}\right) / \sigma_{\mathrm{vo}}^{\prime}
$$

where:

$$
\begin{aligned}
& \mathrm{Q}_{\mathrm{tn}}=\text { normalized cone resistance (tsf) } \\
& \sigma_{\mathrm{vo}}=\text { total overburden stress (tsf) } \\
& \sigma^{\prime}{ }_{\mathrm{vo}}=\text { effective overburden stress (tsf) }
\end{aligned}
$$

The corrected FR used in the Robertson (1990) chart shown in Figure 1-2 is calculated as in Eq. 1, substituting $\mathrm{q}_{\mathrm{t}}$ for $\mathrm{q}_{\mathrm{c}}$.

The normalized friction ratio $F_{s n}$ is calculated as:

$$
\mathrm{F}_{\mathrm{sn}}=\mathrm{f}_{\mathrm{s}} /\left(\mathrm{q}_{\mathrm{t}}-\sigma_{\mathrm{vo}}\right) * 100 \%
$$


The pore pressure ratio $\left(B_{q}\right)$ for the second chart is calculated as:

$$
\mathrm{B}_{\mathrm{q}}=\left(\mathrm{u}-\mathrm{u}_{\mathrm{o}}\right) /\left(\mathrm{q}_{\mathrm{t}}-\sigma_{\mathrm{vo}}\right)
$$

where:

$$
\begin{aligned}
& \mathrm{f}_{\mathrm{s}}=\text { measured friction sleeve resistance (tsf) } \\
& \mathrm{q}_{\mathrm{t}}=\text { corrected total tip resistance (tsf) } \\
& \mathrm{u}=\text { measured generated pore water pressure (tsf) } \\
& \mathrm{u}_{\mathrm{o}}=\text { measured or estimated equilibrium pore water pressure (tsf) } \\
& \sigma_{\mathrm{vo}}=\text { estimated total soil overburden pressure (tsf) }
\end{aligned}
$$

These calculated values are then plotted in Log-Log space and an SCN is assigned to each point based on its location within the boundary curves (Figure 1-2). An average (or weighted average) of the $\mathrm{SCN}$ from the two charts can then be tabulated and provided to the client as an ARA mixed classification number.

\subsubsection{Campanella and Robertson (1983)}

Fugro uses the Campanella and Robertson (1983) soil classification chart, which is an earlier version of the Robertson (1990) classification chart. This chart plots $\mathrm{q}_{\mathrm{c}}$ against $F R$ without correcting for pore pressure or normalizing for overburden stresses (Figure 1-3). This chart is divided into five major soil behavior types. After correcting for offset between the tip and sleeve and averaging the friction sleeve resistance, the $q_{c}$ is plotted against the FR for the particular depth. The data point is assigned a behavior type based on its location within the boundary curves (Figure 1-3). The behavior types are then presented in graphical format on the CPT profile along with the measured and calculated parameters.

\subsubsection{Robertson and Campanella (1989)}

Despite the benefits achieved by the two previous methodologies, Robertson and Campanella (1989) state the following concerning soil classification and the use of CPT in its original purpose, geotechnical design:

"The primary purpose of the CPT and CPTU is for stratigraphic logging and preliminary evaluation of geotechnical parameters. Other in situ test 
methods or sampling and laboratory testing may be better suited for use in critical areas that have been defined by the CPT of CPTU. The CPT or CPTU should be used to determine the locations and elevations at which other in situ tests and/or sampling should be carried out.

Where the geology is uniform and well understood and where predictions based on CPT or CPTU results have been locally verified and correlated with structure performance, the CPT or CPTU can be used alone for design. However, even in these circumstances the CPT or CPTU may be accompanied by boreholes, sampling, and testing for one or more of the following reasons:

1. to clarify identification of soil type

2. to verify local correlations

3. to assist where interpretation of CPT of CPTU data is difficult due to partial drainage conditions or problem soils

4. to assist where the effects of future changes in soil loading are not recorded by the CPT." 


\section{SECTION 1}

\section{FIGURES}




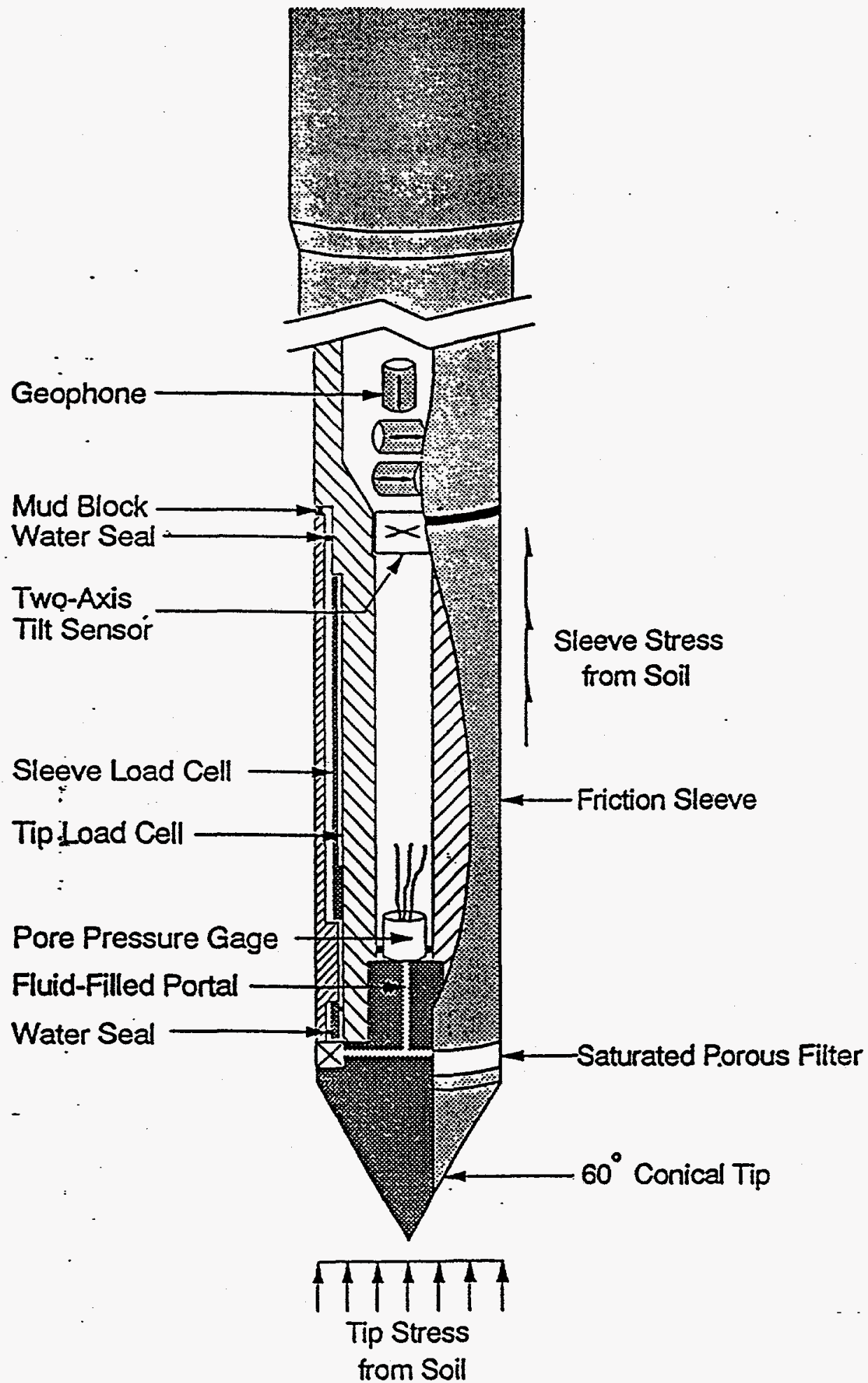

Figure 1-1. Schematic of ARA's Cone Penetrometer Probe (after ARA 1992) 

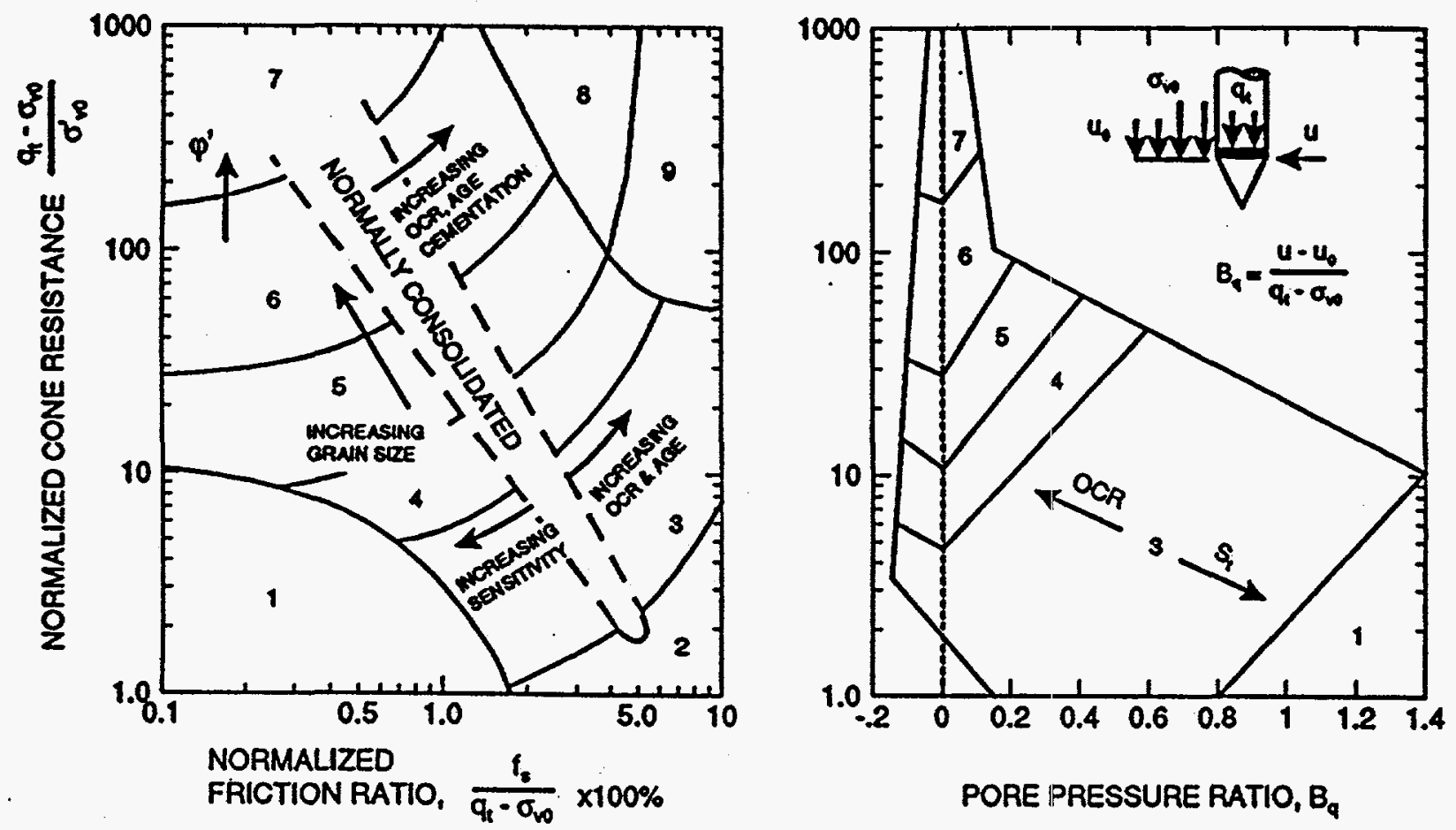

1. SENSITIVE, FINE GRANED

6. SANDS-CLEAN SANO TO SILTY

2. ORGANIC SOILS-PEATS

3. clays-CLAY TO SILTY CLAY

4. SILT MIXTURES-CLAYEYSILT TO SILTY CLAY

5. SAND MIXTURES-SILTY SAND SAND

7. GRAVELLY SANO TO SANO

8. VERY STIFF SAND TO CLAYEY SANO

9. VERY STIFF, FINE GRAINED • TO SANDY SILT

() HEAVIL YVERCONSOLIDATED OR CEMENTED

Figure 1-2. Proposed Soil Behavior Type Classification Chart Developed by Robertson (1990) 


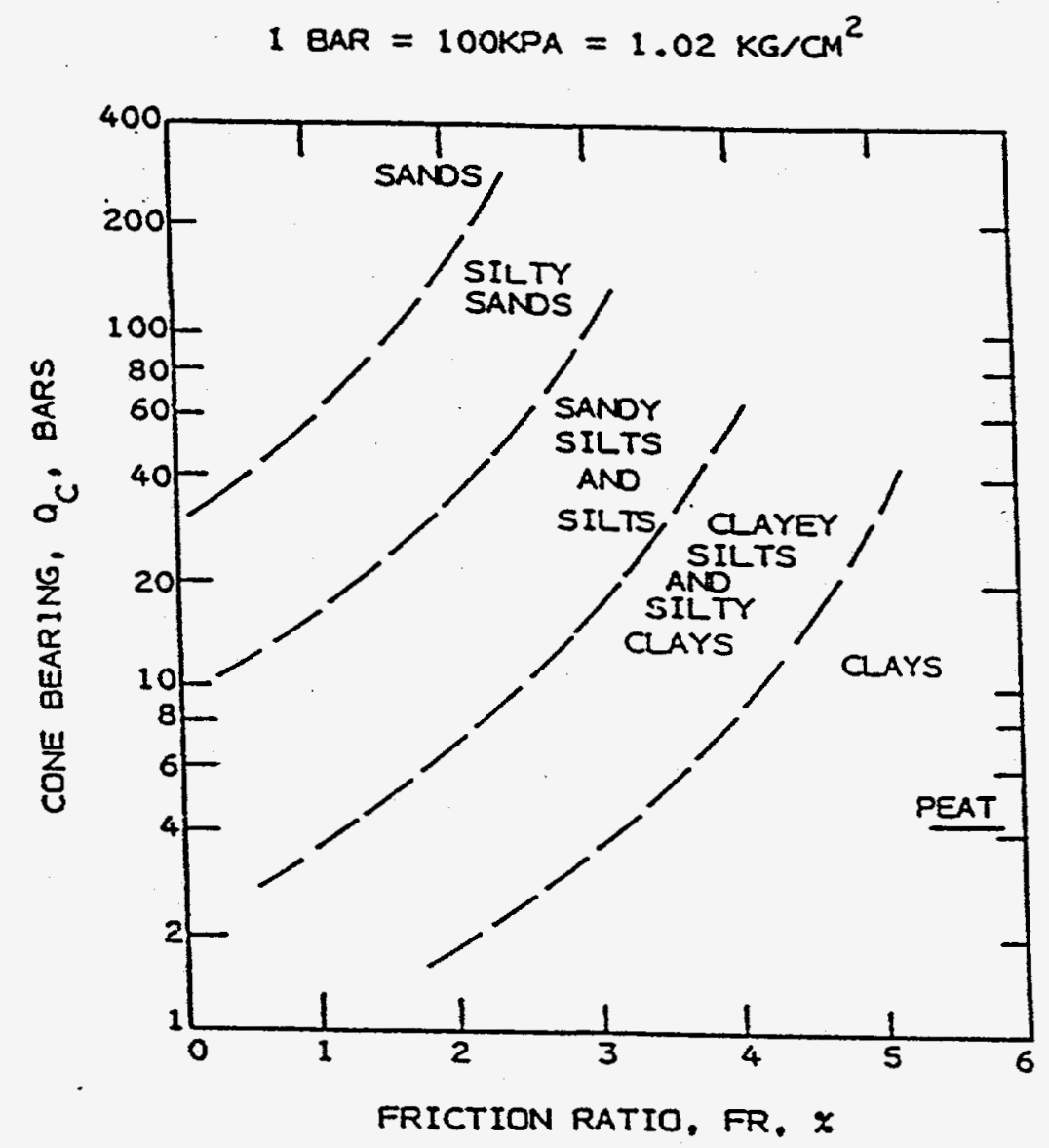

Figure 1-3. Proposed Soil Behavior Type Classification Chart Developed by Campanella and Robertson (1983) 


\subsection{LITERATURE SEARCH}

A literature search was performed to identify recent publications relating CPT to soil classification. The following sources were consulted during the search:

- University of South Carolina (USC)-Aiken Library: On-line computer search

- Search on the Internet's World Wide Web using the Lycos search engine

- Aiken County Library: Requests for interlibrary loan

- Applied Research Associates, Inc.

- University of Florida Library

The University of South Carolina Library in Columbia was contacted to determine which journals or documents identified in the USC Aiken search were available. Their holdings included the Journal of Geotechnical Engineering and the United States Geological Survey (USGS) Water Resources Investigations. However, the articles from these journals did not apply to the correlation of CPT to soil classification.

The internet search identified 36 articles applicable to subject. The results of this search are presented in Appendix A.1.

The results of the USC Aiken computer search are presented in Appendix A.2. Forty references were found that related to the subject. Of these 40 , reprints from the three documents found on pages 5, 7, and 22 of Appendix A.2 were requested through the Aiken County Library. Two of the documents, Zhang (1994) and Jefferies and Davies (1991), were used in this report. The third, Abramson (1994), did not contain any information relevant to this study.

ARA provided copies of two reports relating to the subject. These reports are titled "Piezo-Resistivity Electric Cone Penetration Technology Investigation of the M-Area Basin at the Savannah River Site" and "Piezo Electric Cone Penetration Tests in Support of Geotechnical Investigations at Section 1/9 of Fresh Kills Landfill, Staten Island, New York." 
A preliminary literature search of the Engineering Index through the University of Florida Library identified approximately 80 references. Abstracts from three papers identified during this search are presented in Appendix A.3. 
Paired data sets were compiled from 27 locations at R Area, L Area, H Area, and the Burial Ground Complex. These data sets (in paper and electronic formats) included CPT profiles, lithologic core logs, field logs, geophysical logs, laboratory results of grain-size analysis and permeability, location coordinates, surface elevations, and water table elevations (Table 3-1).

The data sets include CPT tests conducted by Fugro and ARA. Of the 27 locations, five were CPT tests conducted by ARA; the remaining tests were performed by Fugro. During the course of this study, three additional tests were performed in R Area by ARA at locations previously tested by Fugro: RPC-1, RPC-2, and RBW-1. These tests were performed to compare ARA and Fugro methods at similar locations.

Fugro CPT data include depth, tip stress, sleeve friction, and pore pressure measurements. In addition, Fugro measured natural gamma radiation with a separate tool used in all $R$ Area tests and 13 of 17 Burial Ground tests. It should be noted that the tip stress and friction ratio values provided by Fugro do not include a correction for pore pressure or a normalization for overburden stresses. The data set also includes a soil behavior type. Fugro generates their soil behavior type based on the Campanella and Robertson (1983) soil classification chart.

The CPT data provided by ARA consist of depth, sleeve stress, uncorrected (UNC) tip stress, and pore pressure. Resistivity (in ohm-m) is provided in the two L-Area profiles. Calculated values are reported for corrected (COR) tip stress, COR friction ratio, overburden (tsf), effective overburden (tsf), density (pounds per cubic foot [pcf]), relative density (\%), friction ratio classification, pore pressure classification, ARA mixed classification, and blow count (blows/ft). ARA generates their soil behavior type based on the Robertson (1990) soil classification charts.

Lithologic core samples are logged in the Central Shops Area Core Logging Laboratory. The cores are examined on a foot-by-foot basis following the procedures of WSRC-L14.1 (1993). The resulting data include well name, depth, percent recovery, induration, color, and structure. A normalized estimate of the percent siliciclastic gravel, sand, and mud is also recorded. The maximum and modal grain size is estimated, as well as the average 
particle roundness. A normalized estimate is then recorded for the carbonate fraction gravel, sand, and mud. The total percent cement and the percent carbonate are estimated and recorded. Based on the above percentages, a rock name is assigned to the sample. Additional information includes estimates for sorting; porosity; pore type; percentages of muscovite, glauconite, lignite, sulfides, and heavy minerals; and fossil identification (Figure 3-1). The data generated by this method are averaged over a 1-ft interval.

Standard geophysical logs of soil borings or core holes profiling natural gamma, electric resistivity, spontaneous potential, and caliper readings were provided by SRS in paper and electronic format. Along with the geophysical logs, field geologic logs were provided for most of the locations. Water table elevation data were also provided to help estimate static pore pressure at CPT locations that did not monitor this parameter.

Coordinates of CPT and core locations were provided for most of the Burial Ground and H-Area samples; however, the majority of CPT locations in the Burial Ground were assigned the same coordinates and surface elevations as the core (Table 3-2). Therefore, for correlation, it was assumed that locations were within a 10-ft radius.

Results of approximately 175 laboratory tests for either horizontal or vertical hydraulic conductivity were provided from the Burial Ground cores. Twenty-one of these tests had complementary CPT profiles and were below the water table. A report containing air permeability results for select cores contained nine values with corresponding core and CPT data from the Burial Ground (Core Laboratories 1995). An additional 18 permeability tests with corresponding CPT data were provided for R Area (Law Engineering, Inc. 1996).

These data sets were grouped by location and examined individually. All CPT, lithologic core, and geophysical data were compiled into Excel ${ }^{\mathrm{TM}}$ workbooks. The individual data sets for each location were then averaged on a foot-by-foot basis for direct comparison. The CPT sets were also summarized by similar description to be compared to the lithologic core descriptions. 


\section{FIGURES}




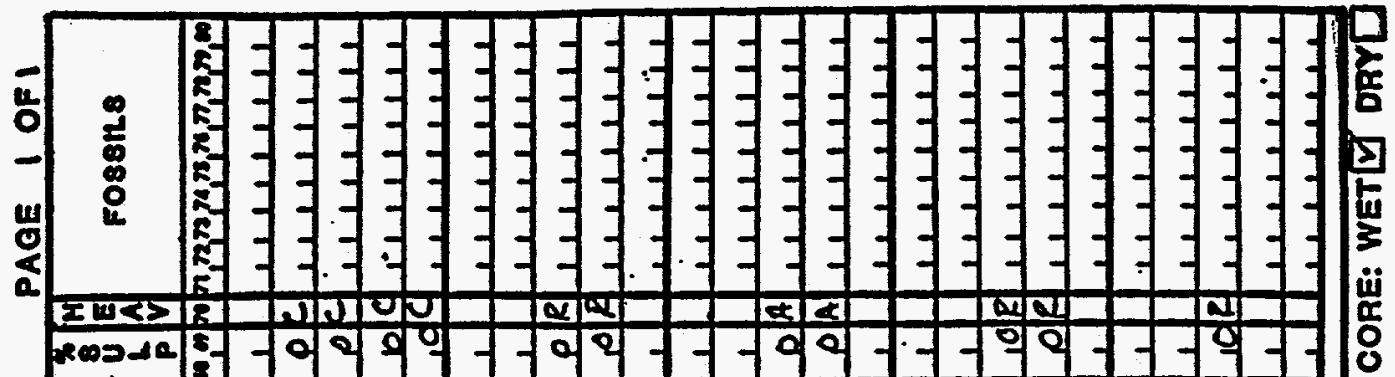

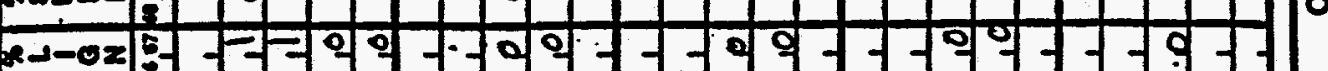

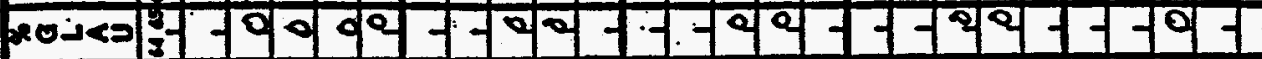

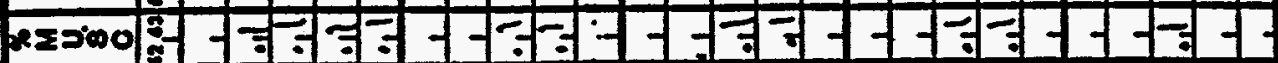

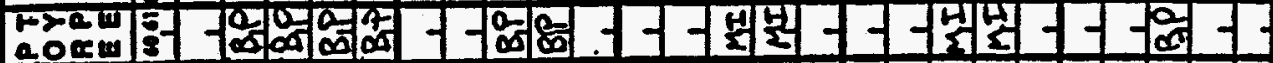

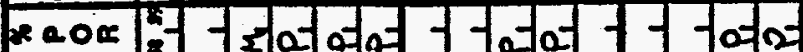

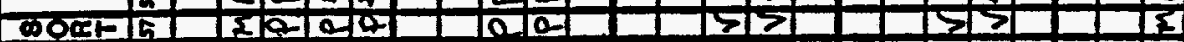

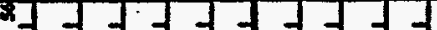

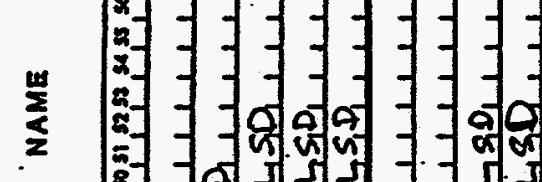

5

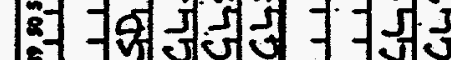

II

$\frac{I}{\infty}$

$\boldsymbol{O}$

I

porate

29

109

$\cos -1$.

ore월

要:

III "reg

(1)

0 एट्रू लाmmm mm

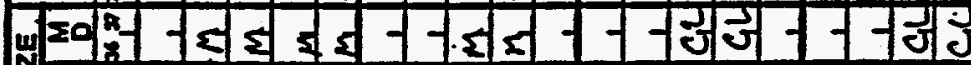

m. $2 \times$ मी

क

to

*:

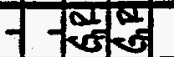

प्रेण

जิ을

연 $7+160$

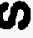

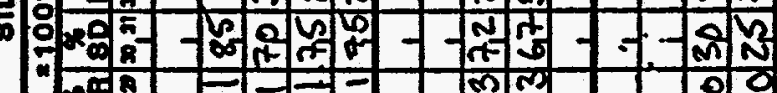
*oğ
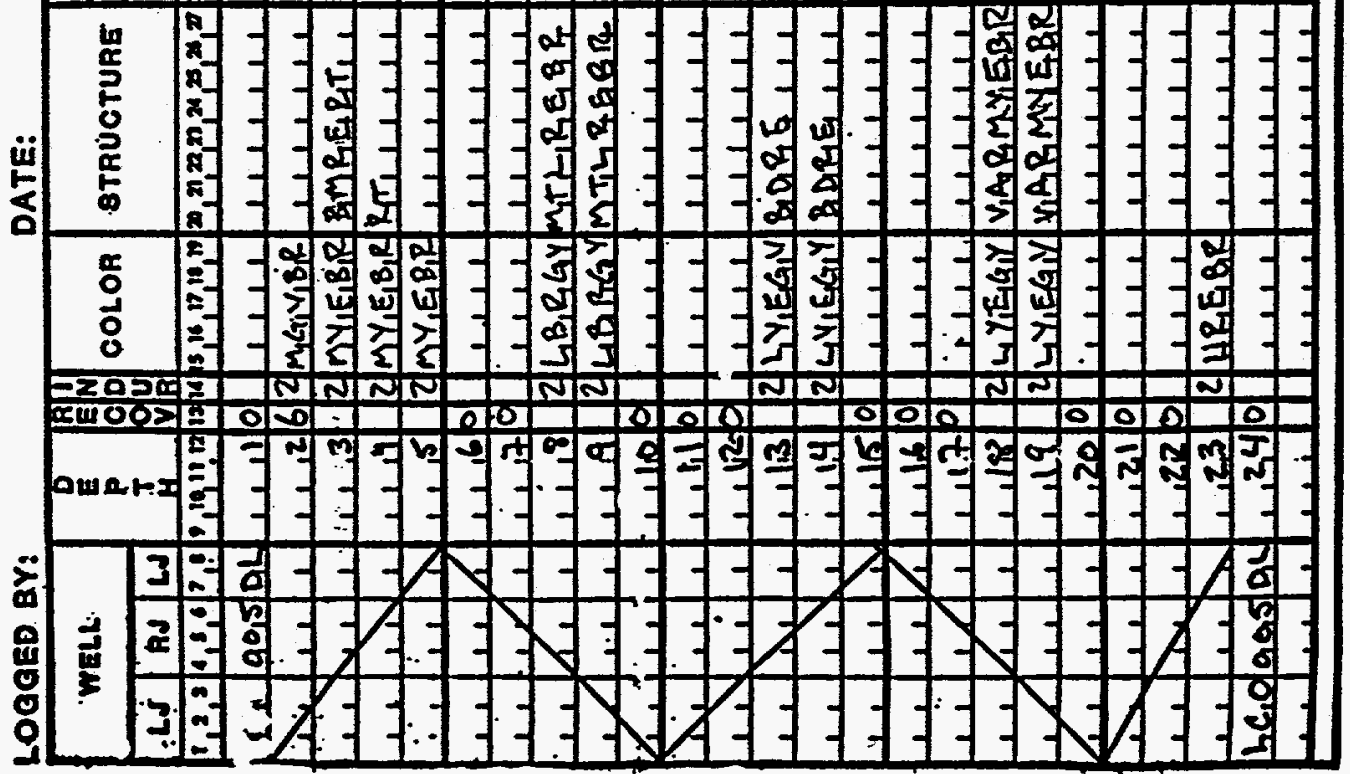


\section{SECTION 3}

\section{TABLES}


Table 3-1. Summary of Data Collected for CPT Correlation

\begin{tabular}{|c|c|c|c|c|c|c|c|c|c|c|c|c|c|c|c|}
\hline \multirow[b]{2}{*}{ Location ID } & \multicolumn{4}{|c|}{ Electronic Copy } & \multicolumn{8}{|c|}{ Paper Copy } & \multicolumn{3}{|c|}{ Location Information } \\
\hline & $\begin{array}{l}\text { CPT } \\
\text { Log }\end{array}$ & $\begin{array}{c}\text { CPT Logs } \\
\text { Geophysical }\end{array}$ & $\begin{array}{c}\text { Geophysical } \\
\text { Lozs }\end{array}$ & $\begin{array}{l}\text { Core } \\
\text { Log }\end{array}$ & $\begin{array}{l}\text { CPT } \\
\text { Loge } \\
\text { Chart }\end{array}$ & $\begin{array}{l}\text { CPT } \\
\text { Logs }\end{array}$ & $\begin{array}{l}\text { CPT Logs } \\
\text { Geophysical }\end{array}$ & $\begin{array}{c}\text { Geophysical } \\
\text { Logs }\end{array}$ & $\begin{array}{l}\text { Core } \\
\text { Logs }\end{array}$ & K-v* & Kh** & $\begin{array}{c}\text { Field } \\
\text { Geologic } \\
\text { Log } \\
\end{array}$ & $\begin{array}{c}\text { CPT } \\
\text { Location }\end{array}$ & $\begin{array}{c}\text { Core } \\
\text { Location }\end{array}$ & $\begin{array}{l}\text { Water } \\
\text { Table } \\
\end{array}$ \\
\hline \multicolumn{16}{|l|}{ Burial Grounds } \\
\hline BGT-03 & $x$ & $x$ & $\mathrm{x}$ & $\mathbf{x}$ & $\mathbf{x}$ & $x$ & $x$ & $\mathrm{x}$ & $\mathrm{x}$ & & & $\mathrm{x}$ & N,E,El. & & \\
\hline BGT-05 & $\bar{x}$ & DNE & $\bar{x}$ & $\bar{x}$ & $\bar{x}$ & $\bar{x}$ & DNE & $\mathbf{x}$ & $x$ & & & $\bar{x}$ & $\mathrm{~N}, \mathrm{E}, \mathrm{EI}$. & N,E,El. & $\bar{x}$ \\
\hline BGT-09 & $\bar{x}$ & $x$ & $x$ & $x$ & $x$ & $x$ & $x$ & $\bar{x}$ & $\bar{x}$ & 1 & 2 & $\bar{x}$ & $\mathrm{~N}, \mathrm{E}, \mathrm{El}$. & $\mathrm{N}, \mathrm{E}, \mathrm{EL}$ & \\
\hline BGT-11 & $\bar{x}$ & $\bar{x}$ & $\bar{x}$ & $\bar{x}$ & $\bar{x}$ & $\bar{x}$ & $\bar{x}$ & $\bar{x}$ & $\mathrm{X}$ & 2 & 2 & $\bar{x}$ & $\mathrm{~N}, \mathrm{E}, \mathrm{El}$. & N,E,EI. & $\bar{X}$ \\
\hline BGT-18 & $\mathrm{X}$ & $\bar{x}$ & $\bar{x}$ & $\bar{x}$ & $\bar{x}$ & $\bar{x}$ & $\bar{x}$ & $\bar{x}$ & $\bar{x}$ & 2 & 2 & $\bar{x}$ & N,E,El. & $\mathrm{N}, \mathrm{E}, \mathrm{E} 1$. & $\bar{x}$ \\
\hline BGT-20 & $\bar{x}$ & $\bar{x}$ & $\bar{x}$ & $\bar{X}$ & $\bar{x}$ & $\bar{x}$ & $\bar{x}$ & $\bar{x}$ & $\bar{X}$ & & & $\bar{x}$ & N,E,El. & N,EEI. & \\
\hline BGT-22 & $\bar{x}$ & $\bar{x}$ & $\bar{x}$ & $\bar{x}$ & $\bar{x}$ & $\bar{x}$ & $\mathrm{X}$ & $\bar{x}$ & $\bar{x}$ & 3 & 2 & $\bar{x}$ & $\mathrm{~N}, \mathrm{E}, \mathrm{El}$ & $\mathrm{N}, \mathrm{E}, \mathrm{E}]$. & \\
\hline BGT-28 & $x$ & $x$ & $\bar{x}$ & $x$ & $\bar{x}$ & $\bar{x}$ & $\mathrm{x}$ & $x$ & $x$ & 1 & 1 & $x$ & $\mathrm{~N}, \mathrm{E}, \mathrm{El}$. & N,E,El. & $\mathbf{x}$ \\
\hline BGT-47 & $\bar{x}$ & DNE & $\bar{x}$ & $\bar{x}$ & $\bar{x}$ & $\bar{x}$ & DNE & $\bar{x}$ & & 2 & 1 & $\bar{X}$ & N,E,El. & $\mathrm{N}, \mathrm{E}, \mathrm{El}$. & $\bar{x}$ \\
\hline BGT-53 & $\bar{x}$ & DNE & $\bar{x}$ & $\bar{x}$ & $\mathrm{X}$ & $\bar{x}$ & DNE & $\bar{x}$ & $\bar{x}$ & 2 & 2 & $\bar{x}$ & $\mathrm{~N}, \mathrm{E}, \mathrm{EI}$ & $\mathrm{N}, \mathrm{E}, \mathrm{El}$. & $x$ \\
\hline BGT-61 & $\bar{x}$ & DNE & $\bar{X}$ & $\bar{x}$ & $\bar{x}$ & $\bar{x}$ & DNE & $\bar{x}$ & $\bar{x}$ & 2 & 2 & $\bar{x}$ & $\mathrm{~N}, \mathrm{E}, \mathrm{El}$. & $\mathrm{N}, \mathrm{E}, \mathrm{E} 1$. & \\
\hline BGT-67 & $\bar{x}$ & $\mathrm{x}$ & $\bar{x}$ & $\bar{x}$ & $\bar{x}$ & $\bar{x}$ & $x$ & $\bar{x}$ & & 2 & 2 & $\bar{x}$ & N,E,El. & $\mathrm{N}, \mathrm{E}, \mathrm{El}$. & \\
\hline SWDT-12/EB-5 & $\bar{x}$ & $\bar{x}$ & $\bar{x}$ & $\bar{x}$ & $x$ & $\bar{x}$ & $\bar{x}$ & $\bar{x}$ & & 2 & 2 & $\bar{x}$ & $\mathrm{~N}, \mathrm{E}, \mathrm{El}$. & $\mathrm{N}, \mathrm{E}, \mathrm{El}$. & $\bar{x}$ \\
\hline SWDT-24/EB-2 & $\bar{x}$ & $\bar{x}$ & $\bar{x}$ & $x$ & $\bar{x}$ & $\bar{x}$ & $\bar{x}$ & $\bar{x}$ & & 0 & 0 & $\bar{X}$ & N,E,El. & N,E,EI. & $\bar{x}$ \\
\hline SWDT-26/EB-3 & $\bar{x}$ & $\bar{x}$ & $\bar{X}$ & $\bar{x}$ & $\bar{x}$ & $\bar{x}$ & $\bar{x}$ & $\bar{x}$ & & 2 & 2 & $\bar{x}$ & N,E,El. & $\mathrm{N}, \mathrm{E}, \mathrm{EI}$. & $\bar{x}$ \\
\hline SWDT-28/EB-4 & $\mathrm{x}$ & $\bar{x}$ & $x$ & $\bar{x}$ & $\bar{x}$ & $\bar{X}$ & $\bar{x}$ & $\bar{x}$ & & 2 & 2 & $\bar{x}$ & $\mathrm{~N}, \mathrm{E}, \mathrm{El}$. & $\mathrm{N}, \mathrm{E}, \mathrm{EI}$. & $\bar{x}$ \\
\hline SWDT-35/EB-1 & $\bar{x}$ & $\bar{x}$ & $\bar{x}$ & $\bar{x}$ & $\mathbf{X}$ & $\bar{x}$ & $\bar{x}$ & $\bar{x}$ & & 1 & 1 & $\mathrm{x}$ & N,E,EI. & $\mathrm{N}, \mathrm{E}, \mathrm{El}$. & $\bar{x}$ \\
\hline \multicolumn{16}{|l|}{ R-Area } \\
\hline RBW-1CL & $\mathrm{x}$ & $\mathrm{x}$ & $\mathrm{X}$ & $\mathrm{x}$ & & $\mathrm{x}$ & $\mathrm{X}$ & & $\mathrm{x}$ & & & & & N,E,El. & $\mathbf{x}$ \\
\hline$R B W-2 C L$ & $\mathrm{X}$ & $\bar{x}$ & $\bar{x}$ & $\bar{x}$ & $\bar{x}$ & $\bar{x}$ & $\bar{x}$ & $\bar{x}$ & $\bar{x}$ & & & $\bar{X}$ & & $\mathrm{~N}, \mathrm{E}, \mathrm{El}$. & $\bar{x}$ \\
\hline $\mathrm{RCH}-1$ & $\bar{x}$ & $\bar{x}$ & $\bar{x}$ & $\bar{X}$ & $x$ & $\bar{x}$ & $\bar{x}$ & $\bar{x}$ & $\bar{x}$ & 6 & 3 & & & & \\
\hline RPC-1CL & $x$ & $\bar{x}$ & $\bar{x}$ & $\bar{X}$ & $\bar{x}$ & $x$ & $\mathrm{X}$ & $\mathbf{X}$ & $\mathrm{X}$ & 5 & 0 & & & $\mathbf{N}, \mathbf{E}, \mathrm{El}$ & $\bar{x}$ \\
\hline $\mathrm{RPC}-2 \mathrm{CL}$ & $\bar{x}$ & $\bar{x}$ & $\bar{X}$ & $\bar{x}$ & $\bar{x}$ & $\bar{x}$ & $\bar{x}$ & $\bar{x}$ & $\bar{x}$ & 3 & 2 & $\mathrm{X}$ & & $\mathrm{N}, \mathrm{E}, \mathrm{El}$. & $\bar{x}$ \\
\hline
\end{tabular}


Table 3-1. Summary of Data Collected for CPT Correlation (continued)

\begin{tabular}{|c|c|c|c|c|c|c|c|c|c|c|c|c|c|c|}
\hline \multirow[b]{2}{*}{ Location ID } & \multicolumn{4}{|c|}{ Electronic Copy } & \multicolumn{7}{|c|}{ Paper Copy } & \multicolumn{3}{|c|}{ Location Information } \\
\hline & $\begin{array}{l}\text { CPT } \\
\text { Log }\end{array}$ & $\begin{array}{l}\text { CPT Logs } \\
\text { Geophysical }\end{array}$ & $\begin{array}{c}\text { Geophysical } \\
\text { Logs }\end{array}$ & $\begin{array}{l}\text { Core } \\
\text { Log }\end{array}$ & \begin{tabular}{|l} 
CPT \\
Logs \\
Chart \\
\end{tabular} & $\begin{array}{l}\text { CPT } \\
\text { Logs }\end{array}$ & $\begin{array}{l}\text { CPT Logs } \\
\text { Geophysical }\end{array}$ & $\begin{array}{l}\text { Geophysical } \\
\text { Logs }\end{array}$ & $\begin{array}{l}\text { Core } \\
\text { Logs }\end{array}$ & $\mathbf{K}-\mathbf{r}^{*} \mathbf{K} \mathbf{h}^{*}$ & $\begin{array}{c}\text { Field } \\
\text { Geologic } \\
\text { Log } \\
\end{array}$ & $\begin{array}{c}\text { CPT } \\
\text { Location }\end{array}$ & $\begin{array}{c}\text { Core } \\
\text { Location }\end{array}$ & $\begin{array}{l}\text { Water } \\
\text { Table }\end{array}$ \\
\hline \multicolumn{15}{|l|}{ L-Area } \\
\hline LCO-05 (CPT-07) & $\mathrm{x}$ & DNE & & $\mathrm{x}$ & & & DNE & & $\mathrm{x}$ & & & & & \\
\hline $\mathrm{LCO}-08$ (CPT-12) & $\mathrm{X}$ & DNE & & $\mathrm{X}$ & & & DNE & & $\mathrm{X}$ & & & & & \\
\hline \multicolumn{15}{|l|}{ H-Area } \\
\hline HTF-Bl & $\mathrm{x}$ & DNE & $\mathrm{x}$ & $\mathrm{x}$ & $\mathrm{x}$ & $\mathrm{x}$ & DNE & DNE & & & $\mathrm{x}$ & $\mathbf{x}$ & $\mathrm{x}$ & \\
\hline HBOR-34 & $\bar{x}$ & DNE & $\bar{x}$ & $\bar{x}$ & $\bar{x}$ & $\bar{x}$ & DNE & DNE & & & $\bar{X}$ & $\overline{\mathbf{X}}$ & $\bar{X}$ & $\bar{X}$ \\
\hline HBOR-SO & $\frac{x}{x}$ & DNE & $\frac{\pi}{x}$ & $\bar{x}$ & $\bar{x}$ & $\bar{x}$ & DNE & DNE & & & $\bar{x}$ & $\bar{x}$ & $\bar{x}$ & \\
\hline HSPT-18 & $\frac{1}{x}$ & DNE & $\bar{x}$ & $\bar{x}$ & $\bar{x}$ & $\bar{x}$ & DNE & $\overline{D N E}$ & & & $\bar{x}$ & $\bar{x}$ & $\bar{x}$ & $\bar{X}$ \\
\hline
\end{tabular}

DNE $=$ Does not exist.

$\mathrm{N}, \mathrm{E}=$ Northing and Easting

El - Elevation

* Numbers listed under $K-v$ and $K-h$ represent the total number of vertical and horizontal permeability values for each location. 
Table 3-2. Summary of Core and CPT Locations

\begin{tabular}{|c|c|c|c|c|c|c|c|c|c|}
\hline \multirow[b]{2}{*}{ Well ID } & \multicolumn{4}{|c|}{ Core Location } & \multicolumn{3}{|c|}{ CPT Location } & \multirow[b]{2}{*}{$\begin{array}{l}\text { Lateral } \\
\text { Distance }\end{array}$} & \multirow[b]{2}{*}{$\begin{array}{c}\text { Elevation } \\
\text { Change }\end{array}$} \\
\hline & Northing & Easting & Elevation & $\begin{array}{c}\text { Water } \\
\text { Table } \\
\text { Elevation }\end{array}$ & Northing & Easting & Elevation & & \\
\hline BGT-03 & $77,197,60$ & $60,045.90$ & 275.70 & 207.70 & $77,197.60$ & $60,045.90$ & 275.70 & 0.00 & 0 \\
\hline BGT-05 & $77,677.60$ & $60,924.10$ & 225.70 & 177.70 & $77,677.60$ & $60,924.10$ & 225.70 & 0.00 & 0 \\
\hline BGT-09 & $78,642.30$ & $59,316.70$ & 226.00 & 168.00 & $78,642.20$ & $59,316.70$ & 226.00 & 0.10 & 0 \\
\hline BGT-11 & $79,566.90$ & $59,697.70$ & 222.50 & 184.50 & $79,566.90$ & $59,697.70$ & 222.50 & 0.00 & 0 \\
\hline BGT-18 & $79,965.30$ & $58,416.50$ & 216.50 & 191.50 & $79,965.30$ & $58,416.50$ & 216.50 & 0.00 & 0 \\
\hline BGT-20 & $80,956.40$ & $58,549.60$ & 159.30 & 151.30 & $80,956.40$ & $58,549.60$ & 159.30 & 0.00 & 0 \\
\hline BGT-22 & 77.680 .30 & $56,970.30$ & 281.00 & 216.00 & $77,680.30$ & $56,970.30$ & 281.00 & 0.00 & 0 \\
\hline BGT-28 & 80.777 .20 & $57,108.10$ & 258.30 & 188.30 & $80,777.20$ & $57,108.10$ & 258.30 & 0.00 & 0 \\
\hline BGT-47 & $77,051.90$ & $54,986.57$ & 317.32 & 217.30 & $77,051.85$ & $54,986.57$ & 317.32 & 0.05 & 0 \\
\hline BGT-53 & $75,837.68$ & $53,422.04$ & 278.25 & 218.30 & $75,837.68$ & $53,422.04$ & 278.25 & 0.00 & 0 \\
\hline BGT-61 & $72,911.77$ & $58,490.09$ & 284.30 & 226.30 & $72,911.77$ & $58,490.09$ & 284.30 & 0.00 & 0 \\
\hline BGT-67 & $74,443.06$ & $60,426.74$ & 242.03 & 237.00 & $74,443.06$ & $60,426.74$ & 242.03 & 0.00 & 0 \\
\hline SWDT-12/OFS-5 & $73,623.00$ & $54,298.00$ & 228.70 & 220.70 & $73,623.00$ & $54,298.00$ & 228.70 & 0.00 & 0 \\
\hline SWDT-24/OFS-2 & $74,671.00$ & $53,848.00$ & 257.50 & 214.50 & $74,671.00$ & $53,848.00$ & 257.50 & 0.00 & 0 \\
\hline SWDT-26/OFS-3 & $74,270.20$ & $54,578.80$ & 258.10 & 222.10 & $74,270.20$ & $54,578.80$ & 258.10 & 0.00 & 0 \\
\hline SWDT-28/OFS-4 & $73,873.80$ & $55,188.30$ & 258.70 & 217.70 & $73,873.80$ & $55,188.30$ & 258.70 & 0.00 & 0 \\
\hline SWDT-35/OFS-1 & $74,975.35$ & $54,049.63$ & 261.60 & 226.60 & $74,975.35$ & $54,049.63$ & 261.60 & 0.00 & 0 \\
\hline RBW-1CL & $62,038.21$ & $74,227.54$ & 284.58 & 252.82 & & & & & \\
\hline $\begin{array}{l}\text { RBW-2CL } \\
\text { RCH-1 }\end{array}$ & $58,711.97$ & $71,795.10$ & 325.12 & 265.94 & & & & & \\
\hline RPC-1CL & $57,923.28$ & $74,261.88$ & 304.28 & 254.98 & & & & & \\
\hline $\begin{array}{l}\text { RPC-1B (ARA-CPT) } \\
R P C-2 C l\end{array}$ & $\begin{array}{l}57,923.26 \\
58,077.18\end{array}$ & $\begin{array}{l}74,261.88 \\
76,12074\end{array}$ & $\begin{array}{l}304.28 \\
292.35\end{array}$ & $\begin{array}{l}254.98 \\
255.75\end{array}$ & $57,954.00$ & $74,292.00$ & 303.50 & 43.04 & 0.78 \\
\hline & & & & & & & & & \\
\hline
\end{tabular}




\section{THIS PAGE INTENTIONALLY LEFT BLANK}




\section{0 CPT, LITHOLOGIC CORE, AND GEOPHYSICAL CORRELATIONS}

\subsection{Soil Classification Correlations}

The most commonly used Soil Classification Chart for CPT data is the one developed by Robertson (1990) (Figure 1-2). Use of this chart involves normalizing both the corrected tip stress (i.e., the tip stress corrected for pore pressure influence on the back side of the tip due to the location of the pore pressure filter) and friction ratio to remove the gravity stress effects that occur due to testing at different depths in the soil environment. Once normalized, the data are plotted in Log-Log space and all data falling within a particular boundary are assigned an SCN. To compare CPT results with soil boring data, all data of a given soil type (e.g., sand, sandy clay, clay), as determined from the boring log for a particular location, are plotted in this Log-Log space.

Figure 4-1 presents a plot of the sand, clayey sand, and clay regions from a single CPT soil boring location (HCPT-11/HBOR-34). As apparent from the plot, there was considerable scatter in the data. Possible reasons for the scatter include depth differences between the boring and the CPT penetration due to core loss, sampling inaccuracies, or layer interface effects due to interbedding. Since not all of these effects could be considered within the time constraints of the project, several layers of very uniform materials were selected from five CPT locations (L-7, L-12, HBOR-34, HTFB-1, and HSPT-18). The core data from these locations were examined in detail, especially the percentage of gravel, sand, and mud. Utilizing these percentages, regions that were very similar were grouped, which yielded more uniform CPT responses over the interval. Figures 4-2, 4-3, and 4-4 present the final grouping of the data and show a reduction in data scatter for these selected locations.

CPT results of intervals described as sand in the core log (presented in Figure 4-2) clearly show the majority of the data classified as sand mixtures to clean sand (Zones 5 and 6 of Figure 1-2). However, some of the data fall outside of this region and could represent transitional materials. It should be noted again that this data set is the best available data and that additional scatter exists when all core lithologic regions are plotted. Most of the additional scatter is due to the mixing of soil particles of different sizes and percentages, which affects the mechanical behavior of the soil. A CPT soil classification chart that is 
based upon soil grain sizes (like the Unified Soil Classification System [USCS]) and considers mixed soil behaviors will reduce data scatter.

Figure 4-3 presents the clayey sand results. These data all tend to group lower and further to the right than the sand data. In terms of Robertson's soil classification numbers, the majority of the data fall in the silty clays to clayey silts regions (Regions 3 and 4, with an emphasis around the lower boundary of Zone 3). Once again, the large amount of scatter is due to a mixture of both sand- and clay-sized grains. This soil description also covers a large percentage of fines (from 25 to 50 percent), which has a significant impact on the CPT response.

The final soil type common in the core data was clay. Figure 4-4 presents the clay results. These data typically plot in Region 3 of the soil classification chart. It is interesting that these values plot above and to the left of the clayey sand region. It would be expected that these data would plot lower and to the right as the percentage of fines in the soil increases. This effect should be investigated further with a larger data base and with sieve and hydrometer analyses of several core samples. It should be noted that the "organic soils" in Robertson's chart (Region 2) are not representative of the SRS soils. For the SRS, Region 2 should be redefined as "soft clayey soils."

Throughout this analysis, there were several regions where the CPT response clearly indicated a clay type soil yet the core description indicated a sandy soil, or vice versa. Many of these instances were eliminated from the data set due to the uncertainty associated. Based upon a preliminary analysis, there appear to be soil zones at the SRS that are misclassified by Robertson's soil behavior chart. These discrepancies typically involve assessment of the fine-grain content of the soil. Currently, it is uncertain how minor changes ( 5 to 10 percent) in percent fines affect the CPT response and, therefore, the soil classification determination. These effects are studied from a field data perspective in this report, but a laboratory evaluation is also warranted. For analytical purposes when predicting soil strength or bearing capacity, minor changes in fines content typically do not produce a noticeable change in soil behavior and, therefore, allow CPT to be effectively used for foundation design activities. However, when predicting soil permeability, which is a goal of this report, these textural changes can have a significant impact and must therefore be considered. 
Another trend in the data set was the lack of regions classified as clayey soils. This trend tended to bias the analysis toward sandy clays or mixed soils and made it difficult to determine the true regions for clayey soils. This observation is most clearly noted in intervals of highly interbedded sands and clays being entirely classified as fine-grained sands in the boring logs, while the CPT results indicate thin layers of clay materials. Many of these thin layers may have been lost due to SRS core logging procedures wherein lithologies are averaged over 1-ft intervals.

The final observation regarding the soil behavior charts pertains to the normalized friction sleeve data $\left(\mathrm{F}_{\mathrm{sn}}\right)$. Significant changes in the friction sleeve data have been observed in CPT results from the SRS. These changes appear to be related to mechanical strength properties and not to changes in the grain-size distribution. This effect can be seen in Figure 4-2 for soils with 15 to 20 percent mud (shown as triangles). The percentage of fine-grained material varies by only 5 percent, with almost no variation in the CPT tip resistance. The normalized sleeve stresses for these soils, however, vary from 0.3 to over 2 and are interpreted to indicate a change in material type when no such change occurred. This effect may be related to the length of the friction sleeve.

The friction sleeve is $16.5 \mathrm{~cm}$ long and tends to measure the average sleeve stresses encountered over a depth interval. This presents a problem when the friction sleeve is in a transition zone from one soil behavior type to another. Friction stresses over this depth interval are a composite of both soil behavior types, which leads to the effects observed in Figures 4-2 through 4-4. This is much less of a problem for the tip and pore pressure measurements, as these sensors are shorter.

Currently there are no published methods for addressing friction sleeve length when attempting to determine soil behavior types. A potential method for correcting this problem is to determine soil layers from tip resistance data and then determine representative tip, sleeve, and pore pressure properties of these layers for determining the soil behavior type.

In summary, it is clear that Robertson's soil behavior chart will misclassify some of the soil layers at the SRS. These soils generally tend to be clean sands, which the CPT soil behavior chart classifies as a sand mixture. The reason for the misclassification is the very high sleeve-friction ratio in these clean sands. Using Robertson's chart, it is difficult 
to accurately separate the sandy clays from the clays because of the high sleeve stresses in the sands.

\subsection{Core Examination}

In early August 1996, cores at the Gunsite Core Depository and the Core Lab at Central Shops were examined to identify discrepancies between CPT soil behavior types and the lithologic core descriptions. Cores OFS-05, BGT-03, BGT-05, RPC-1, LCO05DL, and LCO08 were compared to core and CPT logs. Intervals for examination were determined by comparing the CPT descriptions with the core log descriptions. Locations with clear discrepancies (CPT identifying clay where the core identified sand) were examined, as well as locations showing multiple changes in the CPT description within 1-ft intervals.

When making these comparisons there are a variety of factors that must be considered. These factors include the CPT classification chart used, whether that chart used normalized or measured values, site-specific soil stress states, depth accuracies between CPT and core samples, averaging difference between CPT methods, core logging procedures, and soil cementation effects (if present). These factors can all influence the CPT results; therefore, the comparison between the core logs and the CPT results is an attempt to determine which of these factors are significant and how to compensate for them.

The goal of this investigation was to find intervals, several feet in thickness with varying lithologies, that could be recognized within the CPT log. Changes occurring within $1 \mathrm{ft}$ of core should be delineated by the greater resolution of the CPT (every $2 \mathrm{~cm}$ ) as compared to the core $\mathrm{log}$, which must.be averaged for fines (percent <\#230 U.S. Standard sieve) over a $1-\mathrm{ft}$ interval.

Several of the intervals examined consisted of a primary lithology with interlaminations of coarser- or finer-grained material. The majority of the core sections were consistent with their core log descriptions; however, discrepancies in the CPT log were observed. In some cases, variations in lithology determined by CPT were not visible in the core. In other instances, lithologic breaks observed within the core were not recognized by CPT. One goal of this project is to decrease both the misidentification of lithologies and the excess variation in classifications by generating new site-specific classification curves or by correcting existing curves for use at the SRS. 
A brief description of each examined core section follows. The field notes from this study are located in Appendix B.

\section{QFS-05}

CPT identified clay in several locations of Core OFS-05 that were described as sand by the core log. For example, CPT identified clay from 10.5 to $17.9 \mathrm{ft}$ while the core $\log$ identified sands. For the interval from 15 to $16 \mathrm{ft}$, the core $\log$ identified sand with 10 percent fines. The interval consisted of a sand with white clayey sand laminations from 15.3 to $15.6 \mathrm{ft}$. The 10 percent average value of fines identified by the core log appeared to be correct.

CPT identified clay in the lower section of the $26-27 \mathrm{ft}$ interval, which was identified in the core $\log$ as sand (with 15 percent $\angle \# 230$ ). The interval consisted of a fine to medium tan sand becoming interlaminated with white clayey sand/sandy clay. The overall fines content of this interval was likely greater than 15 percent and exhibited a fining downward, as indicated by CPT.

The interval located between 45 and $46 \mathrm{ft}$ contained three distinct lithologies: a sandy clay (45.0-45.1 ft), a clayey sand (45.1-45.4 ft), and a clean sand (45.4-46.0 $\mathrm{ft}$. The core $\log$ identified this interval as a sand with 6 percent fines, while CPT ranged from clay at the top to silty sand at the bottom.

Below $50 \mathrm{ft}$ CPT identified a number of sand intervals as clays and indicated changes in lithology without core evidence. The core log descriptions appeared to be correct throughout the core. CPT identified clays between 83 and $85 \mathrm{ft}$ in a section of core that contained sands with organic material.

\section{BGT-03}

The intervals examined in core BGT-03 included $114-115 \mathrm{ft}, 122-123 \mathrm{ft}$, and $123-$ $124 \mathrm{ft}$. These samples were chosen based on the discrepancy between the CPT and core results and the presence of carbonate units above and below the intervals. CPT identified these intervals as clays to sandy silts. The intervals from 114-115 and 123-124 ft contained nothing but clean sands with approximately 3 percent fines. The 122-123 ft interval contained 10-15 percent fines. 


\section{BGT-05}

Four intervals were examined from Core BGT-05. These intervals were 10-11, 12-13, 13-14, and 14-15 ft. CPT identified the 10-11 $\mathrm{ft}$ interval as clay to sandy silt while the core indicated a sand with 20 percent fines. Examination of the core revealed that the interval was a medium to coarse sand with interlaminated fines (sandy clay). The $12-13 \mathrm{ft}$ interval was a clay with approximately 85 percent fines; it was identified by CPT as a silty sand. The interval from 13-14 ft was observed to be a clay described by the core log as containing 80 percent fines. CPT characterized this interval as sandy silt and silt from 13.0-13.78 $\mathrm{ft}$ and a clayey silt/silty clay for the remaining $0.2 \mathrm{ft}$. The $14-15 \mathrm{ft}$ interval was identified by both as clay. CPT identified clays below $15 \mathrm{ft}$ in a core "No Recovery Zone." The remaining core was identified as sand by both CPT and the core log.

$\underline{\mathrm{RPC}-1}$

Fourteen intervals from RPC-1 were examined to relate CPT to the core log. The intervals from $10-13 \mathrm{ft}$ were identified by the core $\log$ as clayey sand ( 25 percent fines) and classified by CPT as clays. The interval from 18-22 $\mathrm{ft}$ ranged from a clayey sand ( 30 percent fines) to sands $(15,20$, and 15 percent fines). CPT described these intervals as a mixture of sand and silty sand becoming clayey from $20.2 \mathrm{ft}$ to $22 \mathrm{ft}$. CPT identified the $24-25 \mathrm{ft}$ interval as clay, whereas the core $\log$ indicated a clayey sand with 40 percent fines. The interval from $30-31 \mathrm{ft}$ was identified as clay by CPT and as clayey sand (45 percent) fines by the core log.

Intervals from $110-114 \mathrm{ft}$ were identified by the core $\log$ as sands with 4,5 , and 7 percent fines. The last interval contained some bands of purple silt. CPT identified clays between 112 and $114 \mathrm{ft}$, which were not observed in the core.

CPT identified silty sand from 145.3-149.0 $\mathrm{ft}$ with no changes in lithology. Examination of the core revealed a distinct change in lithology from sand (20 percent fines) to clay ( 85 percent fines) at $147.5 \mathrm{ft}$. 
L-7

The interval from $20-28 \mathrm{ft}$ consisted of primarily sands with 10 percent fines. CPT identified the majority of these intervals as clay or silt. CPT identified sands in agreement with the core log between 43 and $45 \mathrm{ft}$. The sands were clean (0-1 percent fines), well sorted, and medium to coarse grained. The core log for the interval 55-58 $\mathrm{ft}$ indicated sands ranging from 1 to 15 percent fines. CPT identified the range from $55-56$ as varying from sand to silt to clay and $56-58 \mathrm{ft}$ as clay/organic. The interval from $57.5-58.0 \mathrm{ft}$ contained a higher percent fines than the other intervals.

$\mathrm{L}-12$

CPT identified clays from $37-40 \mathrm{ft}$ in L-12 while the core log indicated clayey sand (30 percent fines). Sandy clay/clay was observed between 36.0 and $36.5 \mathrm{ft}$, with the remaining interval consisting of a clayey sand. The interval from 45-46 $\mathrm{ft}$ was also identified by CPT as a clay, but upon examination was a sand with 20 percent fines. A loose sand was encountered at $70 \mathrm{ft}$ that was identified by CPT as clay. The core $\log$ identified it as a sand with 3 percent fines.

Based on observation of these cores, core logs, and CPT data, it appears that CPT not only overestimates the fines content of the sediments, but may identify variations in the soil behavior type that are not evident upon megascopic examination. Secondly, CPT appears to be classifying most clayey sands (with fines $\geq 25$ percent) as clays. Fifty-six intervals were examined and observations recorded. Of those observed, 12 intervals had $\geq 25$ percent fines with 10 identified as clay by CPT. This distinction must be corrected if CPT is to be used for detailed hydrogeologic characterization instead of coring.

\subsection{RPC-1 Detailed Correlation}

Two CPT penetrations, one by Fugro the other by ARA, were made within $10 \mathrm{ft}$ of boring RPC-001. Boring RPC-001 was continuously cored to a depth of approximately $213.5 \mathrm{ft}$ below land surface (bls) utilizing a wireline coring system. The core was described by a field geologist and again at the Core Logging Laboratory. The boring was also geophysically logged for natural gamma emissions (gamma) and resistivity by Graves Environmental and Geotechnical Services (Graves). 
The geophysical logs extend from land surface to total depth, while the core descriptions extend from $10 \mathrm{ft}$ bls to total depth. The Fugro CPT log extended from about $6.5 \mathrm{ft}$ bls (marked $0 \mathrm{ft}$ bls on the $\log$ ) to a depth of approximately $163 \mathrm{ft}$ bls, while the ARA CPT $\log$ extended from about $9 \mathrm{ft}$ bls (marked $0 \mathrm{ft}$ bls on the $\log$ ) to a depth of approximately $174 \mathrm{ft}$ bls. Thus, a lithologic zone noted at about $79 \mathrm{ft}$ bls on the core description would be noted at about $72.5 \mathrm{ft}$ bls on the Fugro CPT log and $70 \mathrm{ft}$ bls on the ARA CPT log.

Table 4-1 presents a detailed comparison of the various logs recorded at boring location RPC-001. Core descriptions, geophysical logs, and Fugro and ARA CPT logs are compared and contrasted over 10-ft intervals from approximately $10 \mathrm{ft}$ bls to approximately $160 \mathrm{ft}$ bls. For this comparison, all logs are corrected for depth as previously described.

\subsection{Geophysical Correlation}

Charts comparing the gamma results of CPT (Fugro) and borehole geophysical (Graves) logs were constructed for the Burial Ground and R-Area sampling locations. These charts allowed direct correlation of the gamma logs. Seventeen locations contained matching data sets. Locations BGT-9, BGT-18, BGT-28, OFS-5, OFS-2, OFS-3, OFS-1, RCH-1, RBW-1, and RPC-2 showed good correlation between the Fugro and Graves data. Locations RPC-1 (described in the previous section) and RBW-2 showed similar plots with a noticeable offset (Figures 4-5 and 4-6). Locations BGT-3 (Figure 4-7), BGT22 (Figure 4-8), and OFS-4 (Figure 4-9) showed a slight correlation. Two locations, BGT-11 (Figure 4-10) and BGT-20 (Figure 4-11), showed little to no correlation.

Results from several of the borehole geophysical logs were compared to the core descriptions to observe the effects of core loss. In most cases, the core log description matched the interpretation of the gamma log. BGT-20 contained several no recovery (NR) zones, yet the geophysical log appeared to agree with the core descriptions. BGT11 showed less of an agreement between the geophysical log and the core description. This could be caused by the high percentage of very fine sands identified in the core description. The geophysical logs and core descriptions for these wells are located in Appendix C. 


\section{FIGURES}




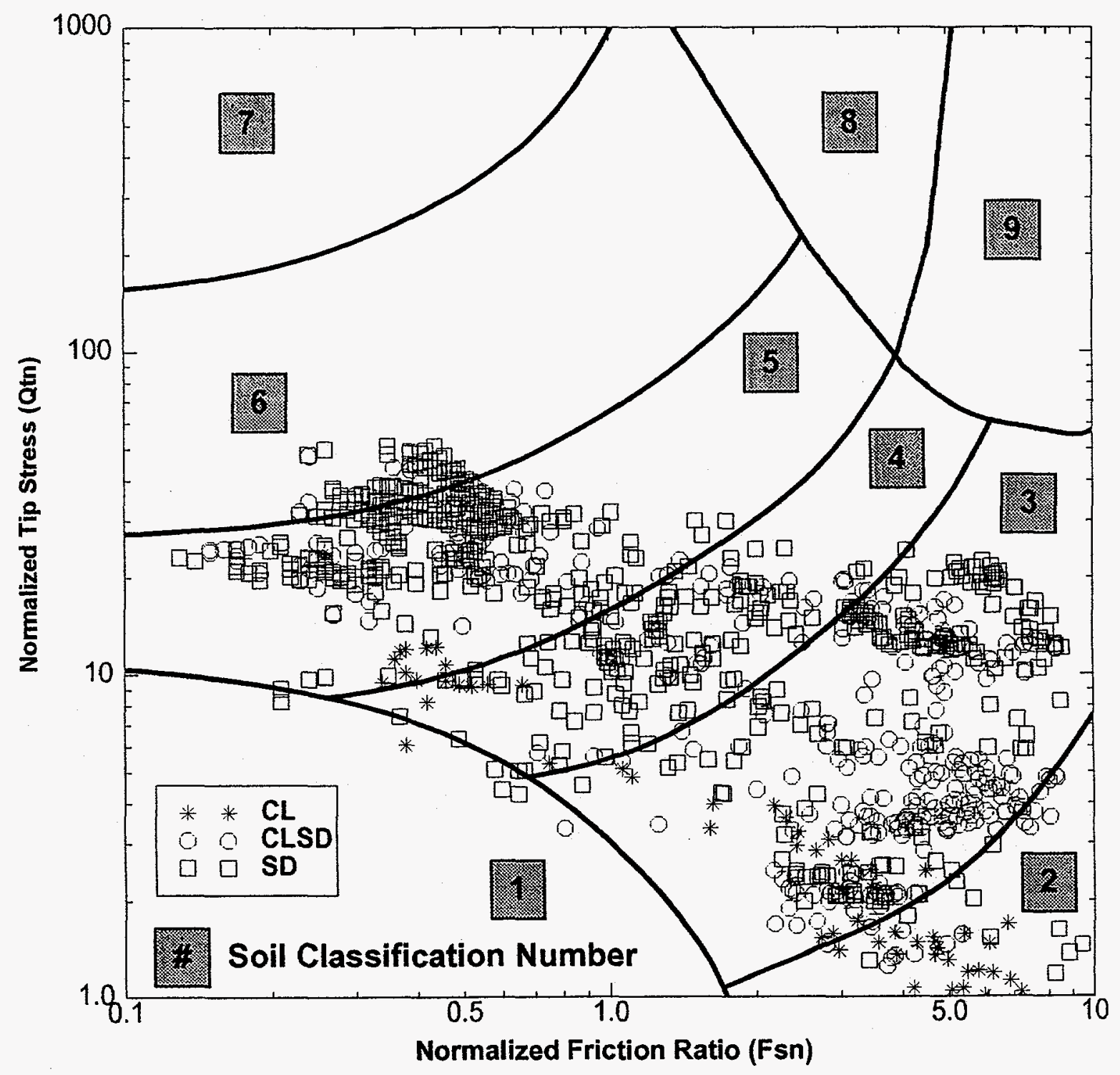

Figure 4-1. CPT Soil Classification Chart For Location HBOR-34/HCPT-11 Showing Large Amounts of Scatter Corresponding to Depth Regions Identified by Three Lithologic Core Soil Categories 


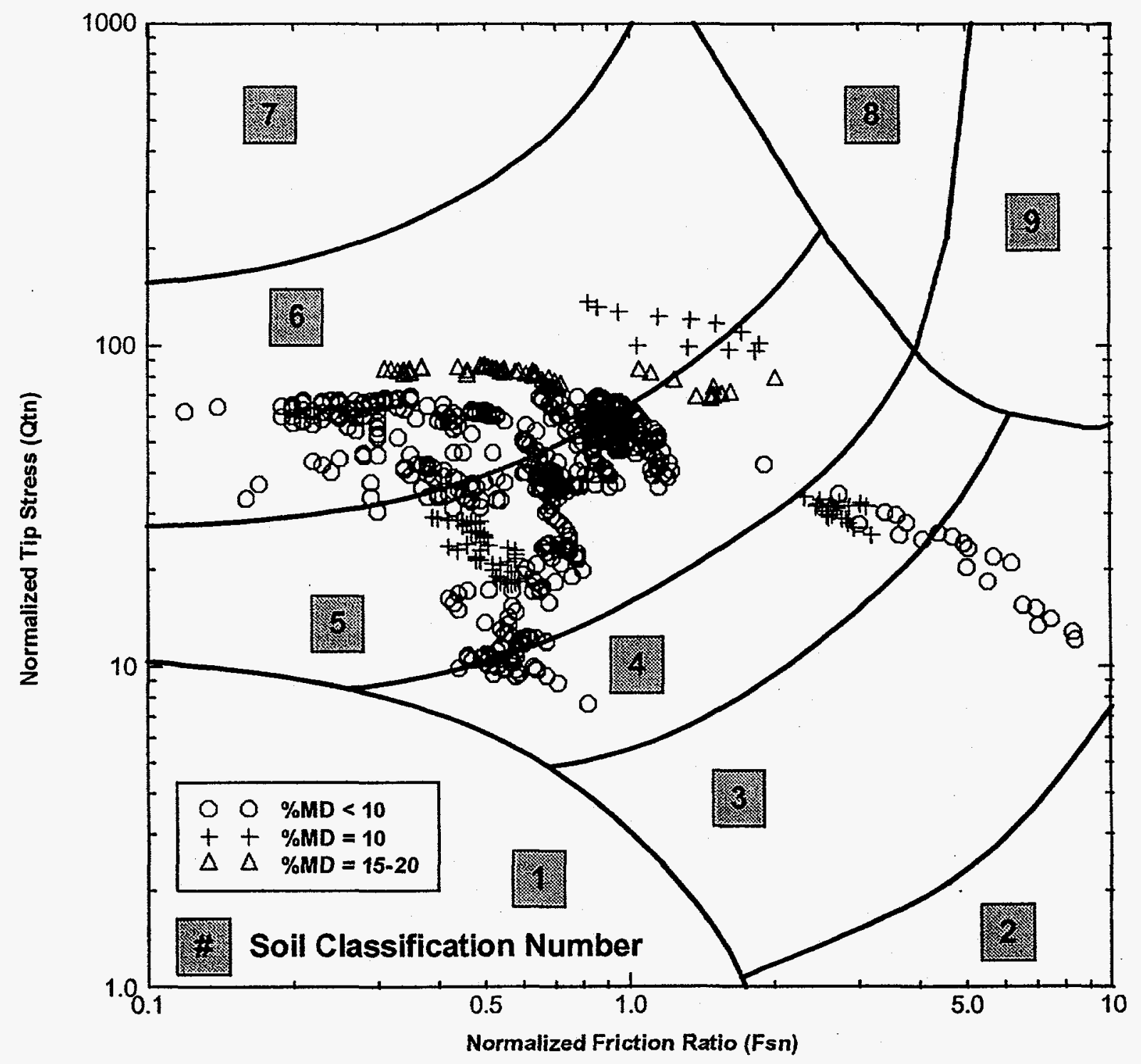

Figure 4-2. Soil Classification Chart Showing Selected Sand Regions Broken Out by Percentage of Mud 


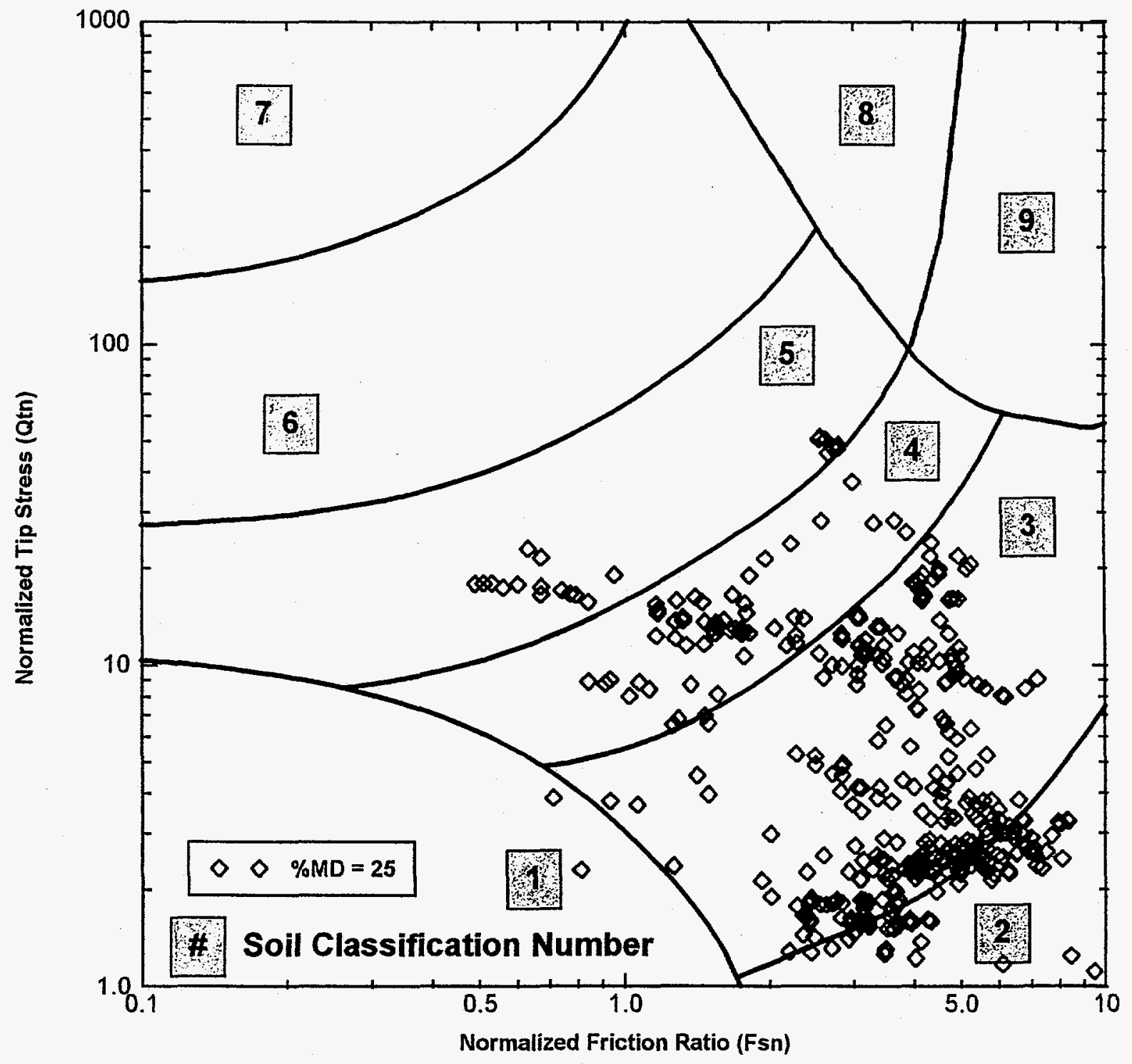

Figure 4-3. Soil Classification Chart Showing Selected Clayey Sand Regions 


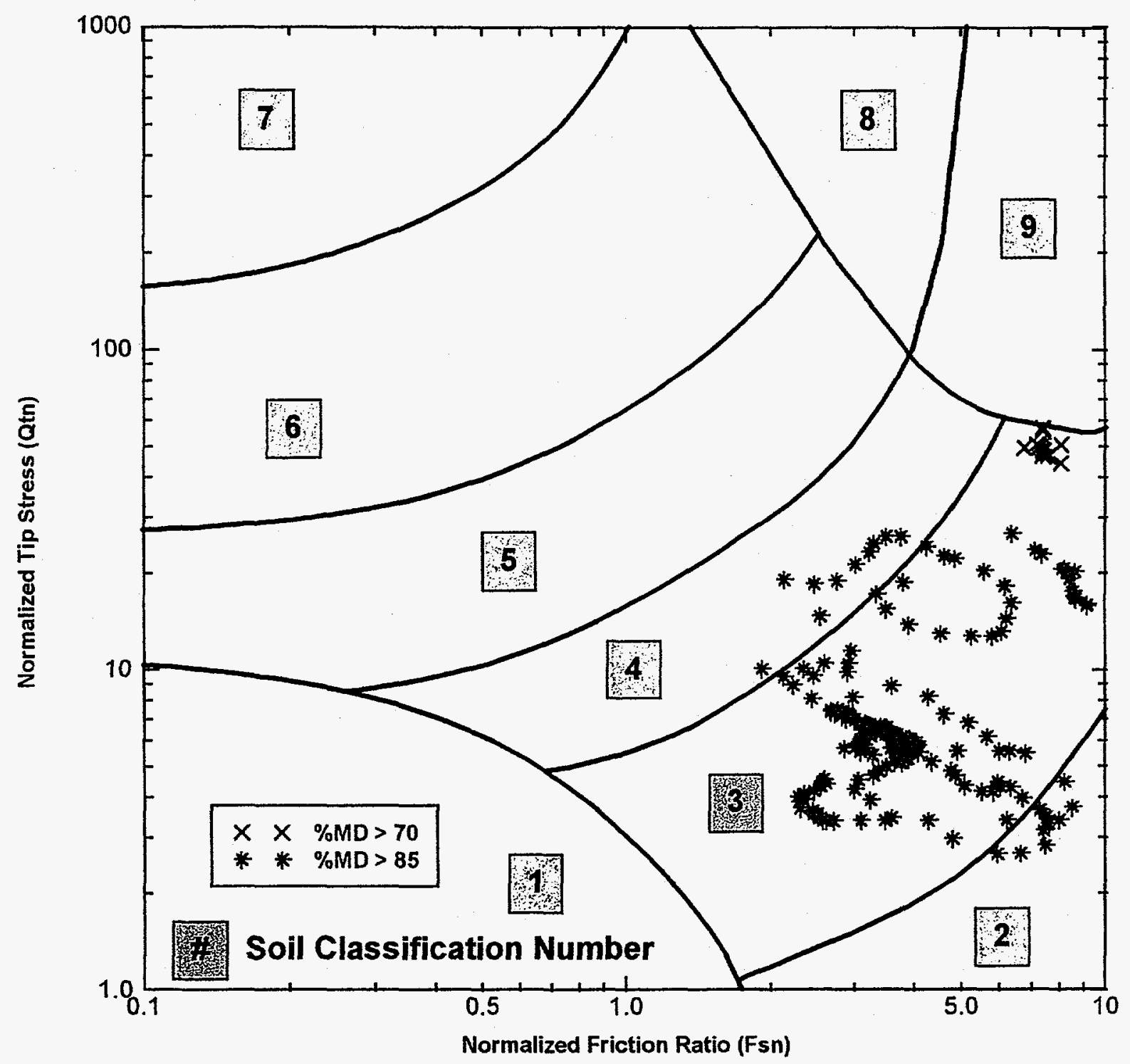

Figure 4-4. Soil Classification Chart Showing Selected Clay Regions 


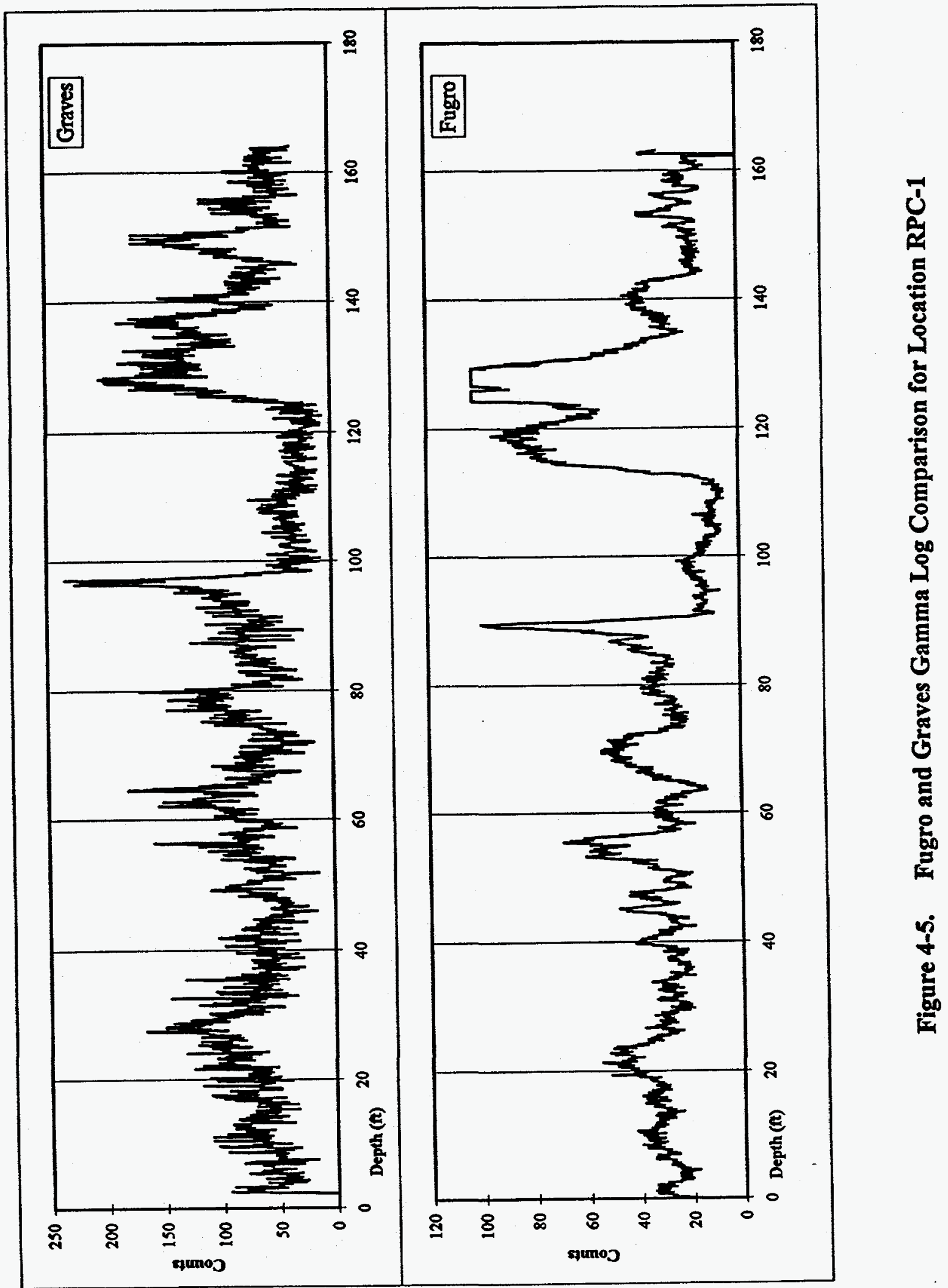




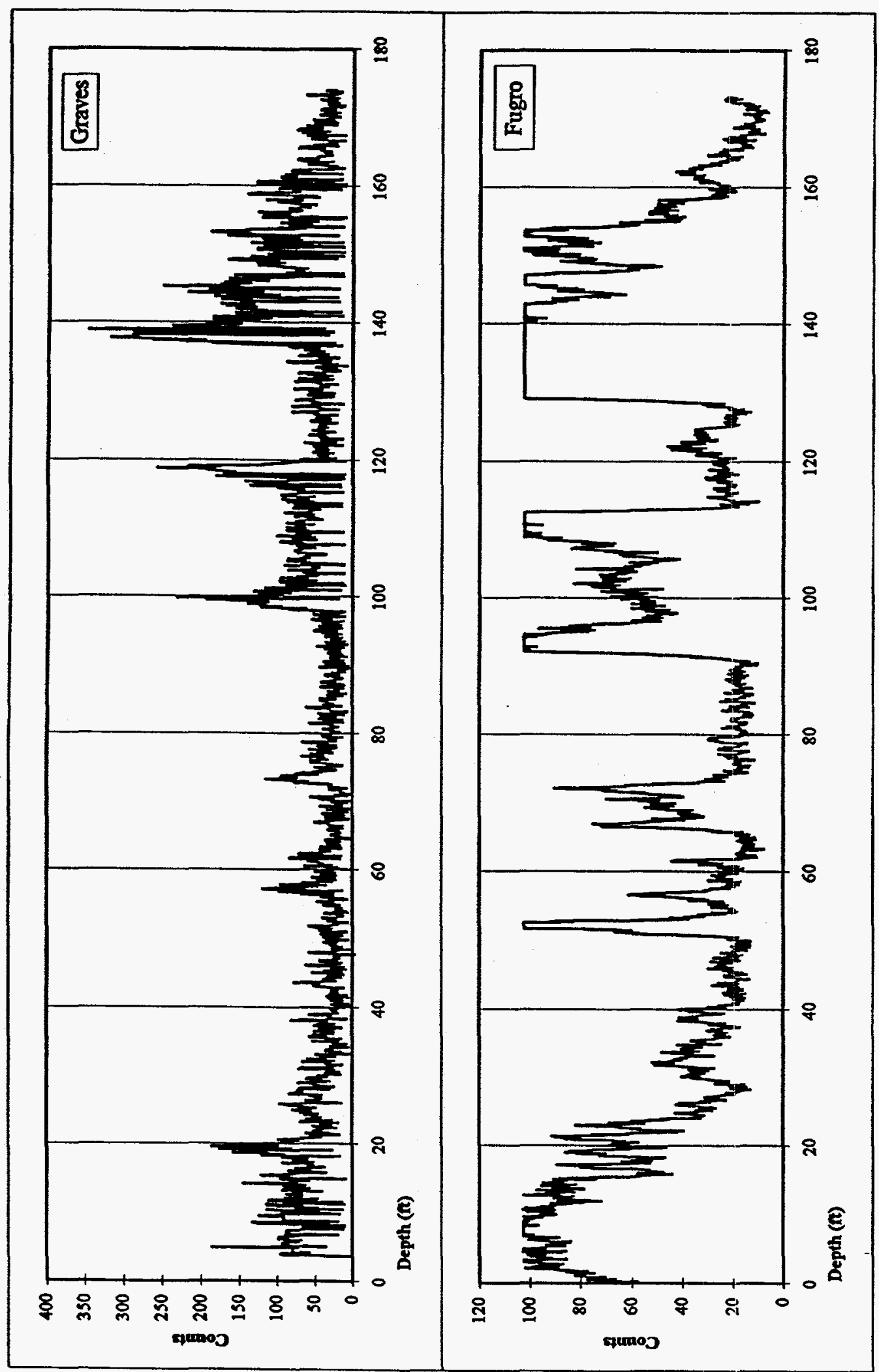

年 


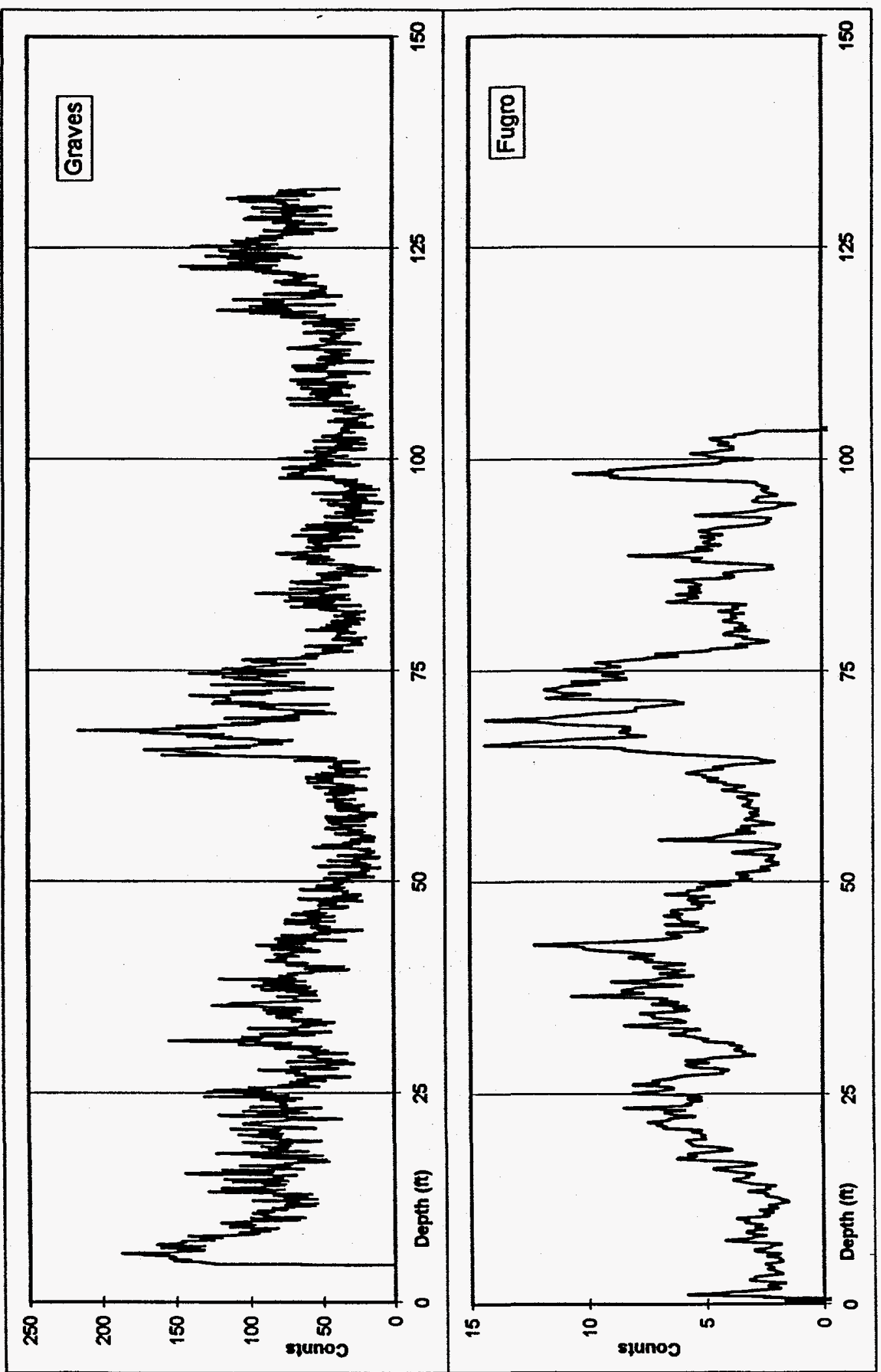

0

字 


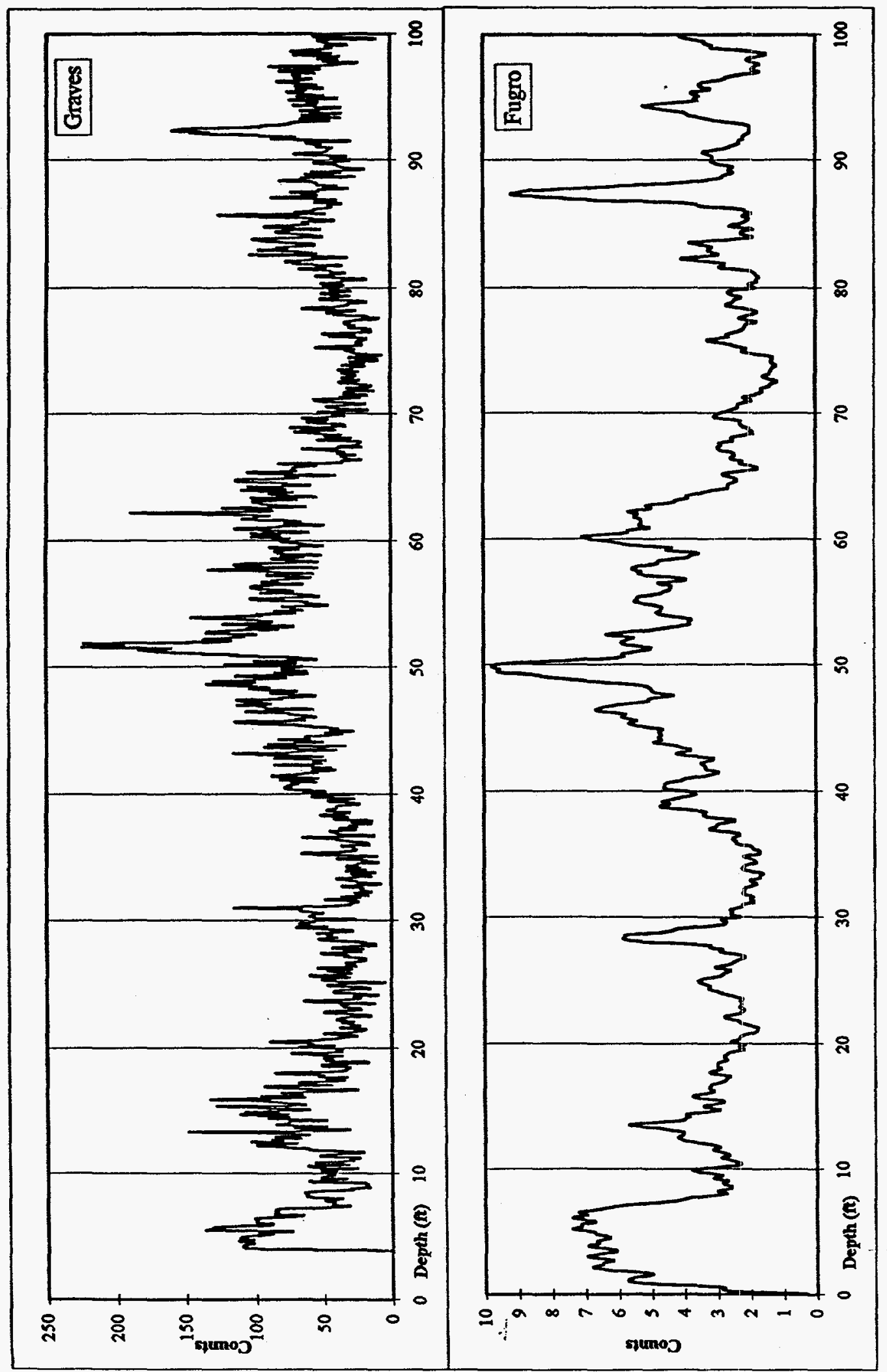

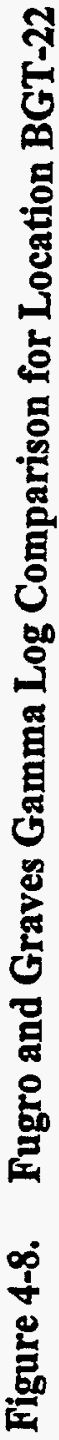

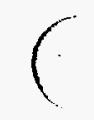




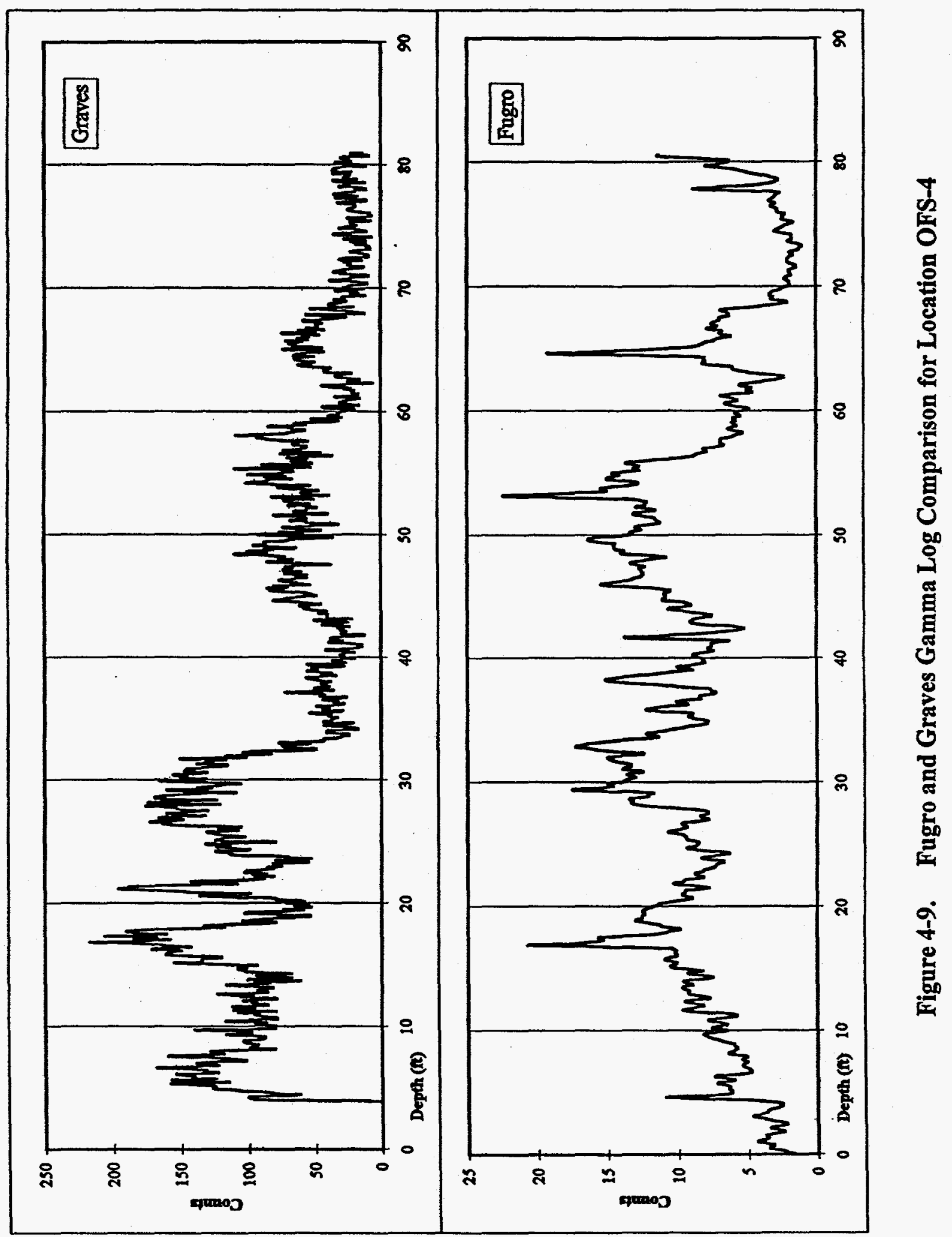




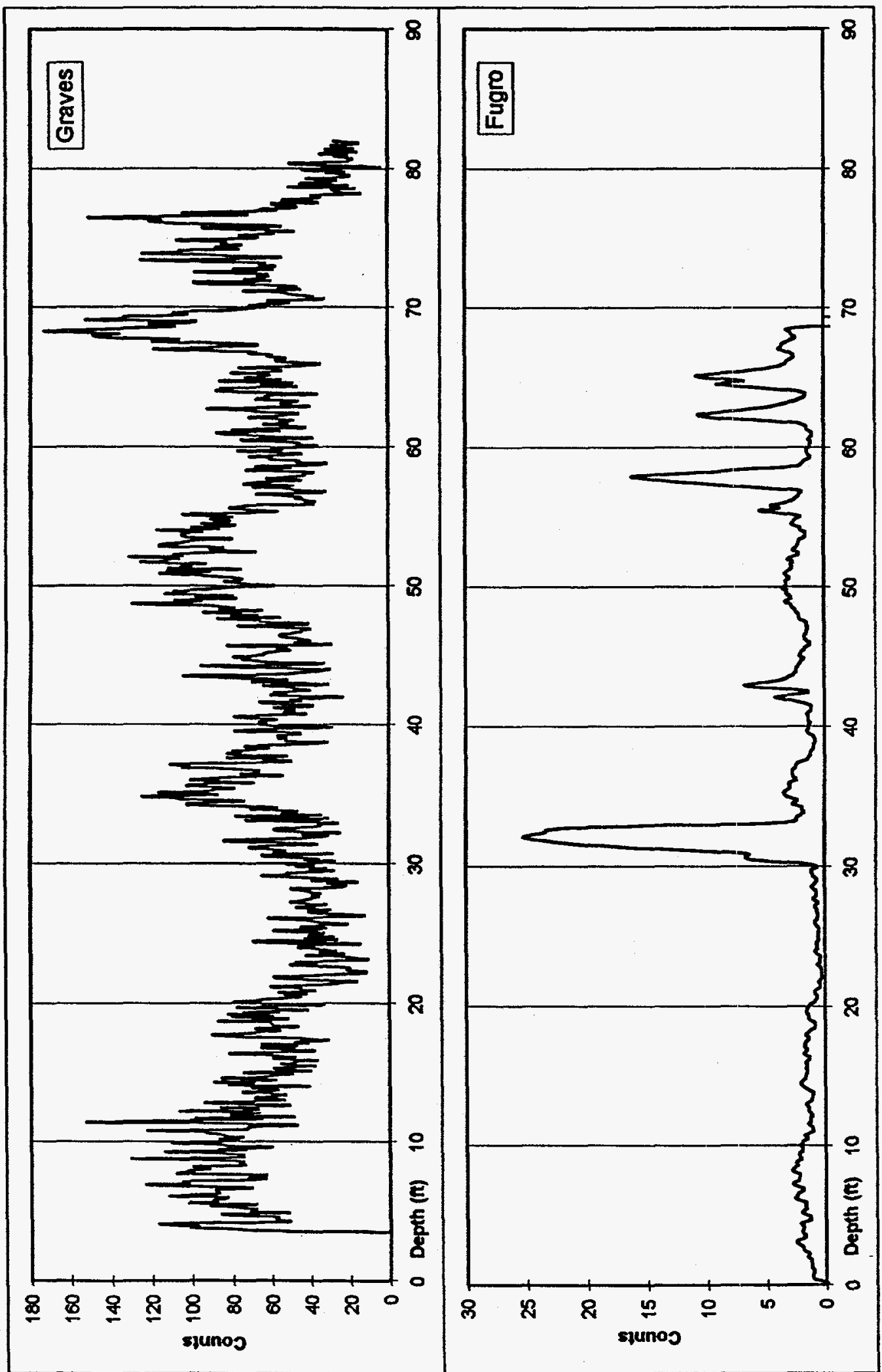

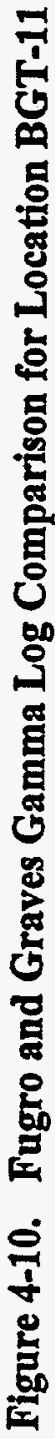




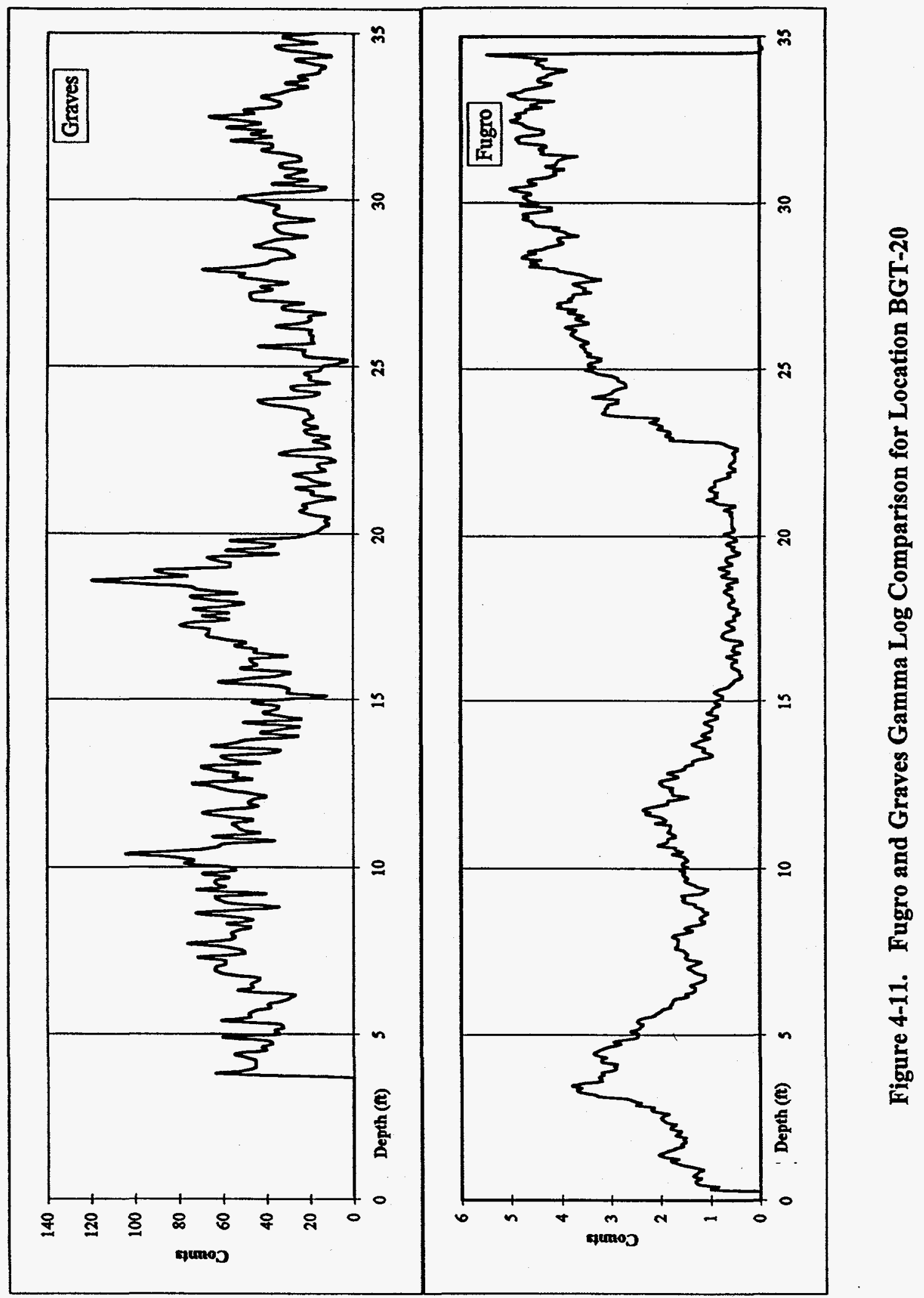




\section{SECTION 4}

\section{TABLES}




\section{THIS PAGE INTENTIONALLY LEFT BLANK}


Table 4-1. Comparison of Geological, Geophysical, and CPT Logs for Location RPC-1

\begin{tabular}{|c|c|c|c|c|}
\hline Interval & Core Description & Gamma & Fugro CPT & ARA CPT \\
\hline $10-20$ feet bls. & $\begin{array}{l}\text { Clayey sand to sand, with } \\
30 \% \text { to } 15 \% \text { fines }\end{array}$ & $\begin{array}{l}\text { Interbedded clayey sand } \\
\text { and sand }\end{array}$ & $\begin{array}{l}\text { Alternating units of clays, } \\
\text { clay-silt mixtures, sand-silt } \\
\text { mixtures, and sands }\end{array}$ & $\begin{array}{l}\text { Alternating units of stiff } \\
\text { clayey to sandy silts, silty } \\
\text { sands, sands, and clays }\end{array}$ \\
\hline 20 - 30 feet bls. & $\begin{array}{l}\text { Sand grading to clayey } \\
\text { sand and sandy clay; } 15 \% \\
\text { to } 55 \% \text { fines. }\end{array}$ & $\begin{array}{l}\text { Sand grading to sandy } \\
\text { clay and clay }\end{array}$ & $\begin{array}{l}\text { Clay-silt mixture, grading to } \\
\text { sand-silt mixture, then to } \\
\text { clay }\end{array}$ & $\begin{array}{l}\text { Stiff silty clay, grading to } \\
\text { sand, then to stiff silty clay } \\
\text { and clay }\end{array}$ \\
\hline $30-40$ feet bls. & $\begin{array}{l}\text { Clayey sand and sandy } \\
\text { clay; } 35 \% \text { to } 55 \% \text { fines }\end{array}$ & $\begin{array}{l}\text { Clayey sand and sandy } \\
\text { clay; \% fines decreasing } \\
\text { with depth }\end{array}$ & Clay & $\begin{array}{l}\text { Clay grading to sandy clay } \\
\text { and silt, then to clay }\end{array}$ \\
\hline $40-50$ feet bls. & $\begin{array}{l}\text { Clayey sand, } 25 \% \text { to } 40 \% \\
\text { fines }\end{array}$ & $\begin{array}{l}\text { Clayey sand; \% fines } \\
\text { decreases then increases } \\
\text { with depth }\end{array}$ & $\begin{array}{l}\text { Clay grading to clay-silt } \\
\text { mixture at base }\end{array}$ & $\begin{array}{l}\text { Clay grading to clay-silt } \\
\text { mixture near base }\end{array}$ \\
\hline 50.60 feet bls. & $\begin{array}{l}\text { Clayey sand, grading to } \\
\text { sand near base; } 40 \% \text { to } \\
20 \% \text { fines }\end{array}$ & Clayey sand & $\begin{array}{l}\text { Clayey to sandy silt, } \\
\text { grading to clay and silty } \\
\text { clay, then to silty sand }\end{array}$ & $\begin{array}{l}\text { Silt-clay mixtures, grading } \\
\text { to sandy silt near base }\end{array}$ \\
\hline 60 - 70 feet bls. & $\begin{array}{l}\text { Alternating sand and } \\
\text { clayey sand ( } 20 \% \text { to } 40 \% \\
\text { fines) at top, grading to } \\
\text { clayey sand }\end{array}$ & $\begin{array}{l}\text { Alternating sand and } \\
\text { clayey sand; possible } \\
\text { radioactive minerals in } \\
\text { sands }\end{array}$ & $\begin{array}{l}\text { Alternating silty sand and } \\
\text { sandy clay at top, grading to } \\
\text { clays and silty clays }\end{array}$ & $\begin{array}{l}\text { Alternating sandy and } \\
\text { clayey silt at top, grading to } \\
\text { silty sand, then to clays near } \\
\text { base }\end{array}$ \\
\hline $70-80$ feet bls. & $\begin{array}{l}\text { Alternating clayey sand } \\
\text { and sand; } 30 \% \text { to } 15 \% \\
\text { fines }\end{array}$ & $\begin{array}{l}\text { Alternating sand and } \\
\text { clayey sand }\end{array}$ & $\begin{array}{l}\text { Alternating clays, clay-silt } \\
\text { mixtures, and silty sands, } \\
\text { grading to sands at base }\end{array}$ & $\begin{array}{l}\text { Clay at top, grading to } \\
\text { alternating silt-clay and } \\
\text { sand-silt mixtures, then to } \\
\text { silty sand at base }\end{array}$ \\
\hline 80 - 90 feet bls. & Sand, $15 \%$ fines & Sand and clayey sand & Sands & Sand-silt mixture \\
\hline $90-100$ feet bls. & $\begin{array}{l}\text { Sand and clayey sand } \\
\text { (15\% to } 30 \% \text { fines), } \\
\text { grading to sand ( } 5 \% \text { fines) }\end{array}$ & $\begin{array}{l}\text { Clayey sand, grading to } \\
\text { silty sand with possible } \\
\text { radioactive minerals, then } \\
\text { to clean sand }\end{array}$ & $\begin{array}{l}\text { Sands at top, grading to } \\
\text { clays and clayey silts, then } \\
\text { to sandy silt and sands }\end{array}$ & $\begin{array}{l}\text { Sand-silt mixture, grading } \\
\text { to silt-clay mixture, then } \\
\text { back to sand-silt mixture }\end{array}$ \\
\hline
\end{tabular}


Table 4-1. Comparison of Geological, Geophysical, and CPT Logs for Location RPC-1 (continued)

\begin{tabular}{|c|c|c|c|c|}
\hline Interval & Core Description & Gamma & Fugro CPT & ARA CPT \\
\hline $100-110$ feet bls. & Sand, $5 \%$ fines & Clean sand & Sands & Sand-silt mixture \\
\hline $110-120$ feet bls. & Sand, $5 \%$ fines & Clean sand & $\begin{array}{l}\text { Sands grading to clays and } \\
\text { clayey silt near base }\end{array}$ & Sand-silt mixture \\
\hline $120-130$ feet bls. & $\begin{array}{l}\text { Sand, } 5 \% \text { fines, grading to } \\
\text { clayey sand, } 25 \% \text { fines } \\
\text { near base }\end{array}$ & $\begin{array}{l}\text { Clean sand grading to } \\
\text { sandy clay near base }\end{array}$ & $\begin{array}{l}\text { Clays and clayey silt, } \\
\text { grading to silty sand and } \\
\text { sands, then to clayey silt } \\
\text { and clays at base }\end{array}$ & $\begin{array}{l}\text { Silty sand at top, grading to } \\
\text { silty clay and clay }\end{array}$ \\
\hline $130-140$ feet bls. & $\begin{array}{l}\text { Clayey sand and sand, } \\
20 \% \text { to } 25 \% \text { fines }\end{array}$ & $\begin{array}{l}\text { Clayey sand and sand } \\
\text { with possible radioactive } \\
\text { minerals }\end{array}$ & Clays and silty clays & $\begin{array}{l}\text { Silt-clay mixture, grading } \\
\text { to clay }\end{array}$ \\
\hline $140-150$ feet bls. & $\begin{array}{l}\text { Clayey sand to sand, } 10 \% \\
\text { to } 25 \% \text { fines, grading to } \\
\text { sandy clay and clay, then } \\
\text { to sand at base }\end{array}$ & $\begin{array}{l}\text { Clayey sand and sand } \\
\text { with possible radioactive } \\
\text { minerals }\end{array}$ & $\begin{array}{l}\text { Clays and silty clays, } \\
\text { grading to silty sand near } \\
\text { base }\end{array}$ & Clay \\
\hline $150-160$ feet bls. & Sand, $5 \%$ to $10 \%$ fines & Sand and clayey sand & $\begin{array}{l}\text { Silty sand grading to sandy } \\
\text { silt }\end{array}$ & $\begin{array}{l}\text { Clay grading to silt-clay } \\
\text { mixture }\end{array}$ \\
\hline $160-170$ feet bls. & $\begin{array}{l}\text { Sand, } 5 \% \text { fines, grading to } \\
\text { clayey sand, then to sand } \\
\text { with fossil shells }\end{array}$ & $\begin{array}{l}\text { Sand and clayey sand, } \\
\text { with possible radioactive } \\
\text { minerals }\end{array}$ & $\begin{array}{l}\text { Alternating sandy silt and } \\
\text { silty sand, silts, clays, and } \\
\text { sands }\end{array}$ & $\begin{array}{l}\text { Alternating sandy silt, silty } \\
\text { clay, silty sand, and clay }\end{array}$ \\
\hline
\end{tabular}




\subsection{PERMEABILITY CORRELATIONS AND CURVES}

A spreadsheet containing over 175 tests for either vertical or horizontal hydraulic conductivity $(\mathrm{K})$ was provided by SRS. However, only 15 of the vertical and 11 of the horizontal laboratory results corresponded to locations and depths (below the water table) where CPT data were available. Several different types of analyses were performed on this data set to develop a complete understanding of the data. The first analysis plotted the horizontal hydraulic conductivity $\left(\mathrm{K}_{\mathrm{h}}\right)$ data against the vertical conductivity $\left(\mathrm{K}^{v}\right)$ data to assess any anisotropic behavior in the data. As shown in Figure 5-1, a large majority of the data is isotropic. Based upon Figure 5-1, the logarithmic average of the horizontal and vertical conductivities was used in all subsequent analyses. Figure 5-1 also indicates that the majority of the data set is material with a conductivity less than $1 \times 10^{-6} \mathrm{~cm} / \mathrm{sec}$. This indicates that there is a bias in the data set and, therefore, developed correlations are more uncertain in sandy soil types (i.e., higher conductivity values) than in finer grained soils.

The next analysis compared the percentage of fines to permeability. Figure 5-2 presents the resulting data set along with the line of best fit. Other researchers (Holtz and Kovacs 1981, Hazen 1911) have developed correlations similar to the one developed using this data set. The trend line indicates that, in sands, the addition of a few percentages of fines may cause a significant difference in the hydraulic conductivity, while the effect of additional fines in clayey soil is not as significant. Figure 5-2 also presents the lines of one and two standard deviations from the line of best fit, with nearly all data falling within two standard deviations.

Since a reasonable correlation was developed between the percentage of fines and permeability and since the CPT friction ratio measurement is related to the relative percentages of sands and clay, it should be expected that the friction ratio would also compare favorably to the permeability. Normalized friction ratio $\left(\mathrm{F}_{\mathrm{sn}}\right)$, as calculated in the soil classification analysis, was used since gravity stresses influence the CPT results but not the permeability estimates. Figure 5-3 presents an analysis of variance (ANOVA) of the permeability data points from the Burial Ground Complex. To reduce scatter, the CPT measurements for each 1-ft sample interval were averaged prior to use in the analysis. The correlation between normalized friction ratio and permeability for the 
averaged data set is presented in Equation 6 below. The correlation has a regression coefficient of 0.53 , which still indicates significant data scatter.

$$
\log K(\mathrm{~cm} / \mathrm{sec})=-4.909-0.606 \mathrm{~F}_{\mathrm{sn}}
$$

It should be noted that this correlation is based only upon the Burial Ground data points and not the data from $R$ Area or the air permeability data from the Burial Ground. Attempts were made to use the R-Area data (Table 5-1), but they significantly reduced the correlation coefficients that were obtained (Figures 5-4 and 5-5). These data were, however, very similar to the Burial Ground when comparing permeability to percent fines (Figure 5-6). The most likely explanation for the reduction in correlation is differences in the soil characteristics between $R$ Area and the Burial Ground Complex. The air permeability results (Table 5-2) also were not used in these analyses because they generated a reverse correlation (Figure 5-7), likely caused by the presence of calcareous zones.

Another CPT parameter that should correlate to the permeability is the pore pressure measurement. Pore pressure analysis typically shows high excess pore pressures in finegrained soils but not in coarse-grained soils. The effects of gravity and different hydrostatic stresses must be removed from the data by normalizing the pore pressure measurements using Equation 5. The CPT measurements were again averaged over 1-ft sample intervals and a regression analysis was performed on the averaged data to look for possible correlations. The resulting correlation coefficient $(0.290)$ was not nearly as strong as that developed from the normalized friction ratio $(0.53)$. This indicates that $B_{q}$ alone can not be used to estimate permeability and that the relationship between $B_{q}$ and permeability is weak.

Although the $\mathrm{B}_{\mathrm{q}}$ relationship to permeability was weak, a two-variable regression analysis using both normalized friction ratio and $\mathrm{B}_{\mathrm{q}}$ was performed. This regression appears to perform slightly better than the $F_{\text {sn }}$ relationship alone, as evidenced by a correlation $\because$ coefficient of 0.56 . The result in this analysis was no longer a line, as in the single variable regressions, but rather a planar surface. For the limited data available, the planar regression surface provides a good fit. As more data become available, other surfaces that utilize polynomial expressions of either or both variables should be investigated. 
Since none of the regression techniques produced correlations with high confidence levels (i.e., correlation coefficients greater than 0.75), other techniques for the determination of permeability were evaluated. One of the most common approaches is to relate the permeability to soil type (Taylor 1948, Masch and Denny 1966, Bear 1972, and Todd 1959). Typically a grain-size parameter such as $D_{10}$ (grain size at which only 10 percent of the sample is smaller) or $D_{50}$ is used, but occasionally only the soil description is used. Freeze and Cherry (1979) have summarized the variation in permeability (hydraulic conductivity) as a function of soil type, as shown in Figure 5-8.

Using the concept of relating permeability to soil type, ARA has developed a technique for using the CPT-derived soil classification values to estimate permeability. The basis for this approach is that permeability generally decreases as the mean soil grain size decreases from sand to clay. Using this concept, permeability should decrease along a line from the upper left to the lower right in the soil classification plot. This line in the soil classification plot correlates with decreasing soil classification numbers. Therefore, permeability can be roughly estimated using Equation 7 . In this equation, the permeability decreases as the soil classification value decreases along the line from upper left to the lower right in the classification plot.

$$
\mathrm{K}(\mathrm{cm} / \mathrm{sec})=10^{(\mathrm{SCN}-9.91)}
$$

The soil-classification-based method for estimating permeability, as described in Equation 8, was used to estimate the permeability of each point in the data base. These estimates were then compared to the actual laboratory values and the absolute value of the percent error was calculated, as shown in Table 5-3. For analyses using the soilclassification-based method, the average percent error in logarithmic space for all 15 data points was 29.3 percent. The permeability of each data point was also calculated using Equation 6 (the regression analysis based solely on normalized friction ratio), and the absolute value of the percent error was determined to be 31.7 percent, as presented in Table 5-3.

Based upon this analysis, both methods are equally valid approaches to determining permeability from CPT data. Closer analysis of Table 5-3 reveals that the two data points from RPCH1 at a depth of 127 to $128 \mathrm{ft}$ cause a significant amount of the average error. If these two points are eliminated, then the $\mathrm{F}_{\mathrm{sn}}$ regression technique produces an average error of 19 percent and the soil classification procedure produces an average error of 20.6 
percent. This tends to slightly favor the regression technique over the soil classification technique. In arithmetic space this percent error translates to approximately one order of magnitude variance in the permeability values.

To further examine the two approaches, comparison profiles were made of three of the locations from the $\mathrm{R}$ Area. The profiles were selected because several laboratory permeability tests were conducted on the cores from these locations. Figure 5-9 presents the CPT data from RCH1 along with the calculated permeability using both the friction ratio regression and the soil classification techniques. The permeability estimate from the soil classification procedure is presented in the middle profile on the second page of Figure 5-9. The solid line in this profile represents the estimated permeability. The dashed line represents an estimate of the permeability based upon the correlation between percent fines and permeability. Finally, the circles represent the results of actual laboratory tests. The soil classification procedures agree fairly well with the laboratory test results, especially below $20 \mathrm{ft}$. The percent fines correlation also compares favorably to the laboratory data; however, the soil classification procedure estimates significantly higher permeability values in the gravelly sand material types than the laboratory data. The third profile on the second page of Figure 5-9 presents the same information again, except that the permeability estimate based on the soil classification procedure is replaced with the $\mathrm{F}_{\mathrm{sn}}$ regression technique. The $\mathrm{F}_{\mathrm{sn}}$ regression technique compares better with the percent fine estimate than the soil classification procedure, especially in the sandy materials at this location. The $\mathrm{F}_{\mathrm{sn}}$ regression technique also tends to predict lower permeability in the clay materials. It should be noted that, for the $\mathrm{F}_{\mathrm{sn}}$ regression technique, all values with a normalized friction ratio greater than 4.5 were set to a permeability of $1 \times 10^{-8} \mathrm{~cm} / \mathrm{sec}$.

Overall, the comparison from both techniques at this location are encouraging and provide reasonable estimates. Caution should be used when applying the soil classification procedure in gravelly sand materials and the $\mathrm{F}_{\mathrm{sn}}$ regression correlation in the clayey materials.

Figure 5-10 presents the same analysis as presented in Figure 5-9 for location RPC-2. The permeability profile that is estimated based upon the soil classification technique is again presented in the middle profile. The estimated profile compares favorably with the laboratory data, except at depths of 9 and $14 \mathrm{ft}$. For this sample, the soil classification procedure estimates a permeability value that is too high. In comparison to the 
correlation based upon fines content, the method agrees with the soil classification technique, estimating slightly higher values in the sand regions. The correlation based upon friction ratio is presented in the third profile of Figure 5-10. This technique does a better job of estimating the permeability at the 14- $\mathrm{ft}$ depth, but does not agree with the laboratory data at a depth of $34 \mathrm{ft}$. Once again, all clay materials are estimated at $1 \times 10^{-8}$ $\mathrm{cm} / \mathrm{sec}$ permeability, whereas the laboratory result was $1 \times 10^{-6} \mathrm{~cm} / \mathrm{sec}$. In comparison to fines content profiles, the $F_{s n}$ estimate provides good correlation except in the clay materials, where the $F_{s n}$ regression equation underpredicts permeability values.

The final comparison profile is from location RPC-1 and is presented in Figure 5-11. Comparison between the laboratory results and the soil classification correlation technique provides fair agreement at $30 \mathrm{ft}$, overpredicts both samples at the 78 - $\mathrm{ft}$ depth, and then underpredicts the samples at the $128-\mathrm{ft}$ depth. The samples at the $78-\mathrm{ft}$ depth are in a sandy material and, therefore, this underprediction is typical of the correlation. The deeper samples have CPT responses that indicate a clayey material, but the permeability values from the laboratory tests indicate a sandy material. These are the same two samples discarded from the analysis in Table 5-3. The friction ratio $\left(\mathrm{F}_{\mathrm{sn}}\right)$ correlation technique also underpredicts the permeability at the $128 \mathrm{ft}$ depth. This technique produces a more accurate estimate at the 78- $\mathrm{ft}$ depth, but again underpredicts the sample at $30 \mathrm{ft}$. Once again, the $30-\mathrm{ft}$ sample was from a clay layer, where the $F_{s n}$ estimates are known to be low. 


\section{SECTION 5}

\section{FIGURES}




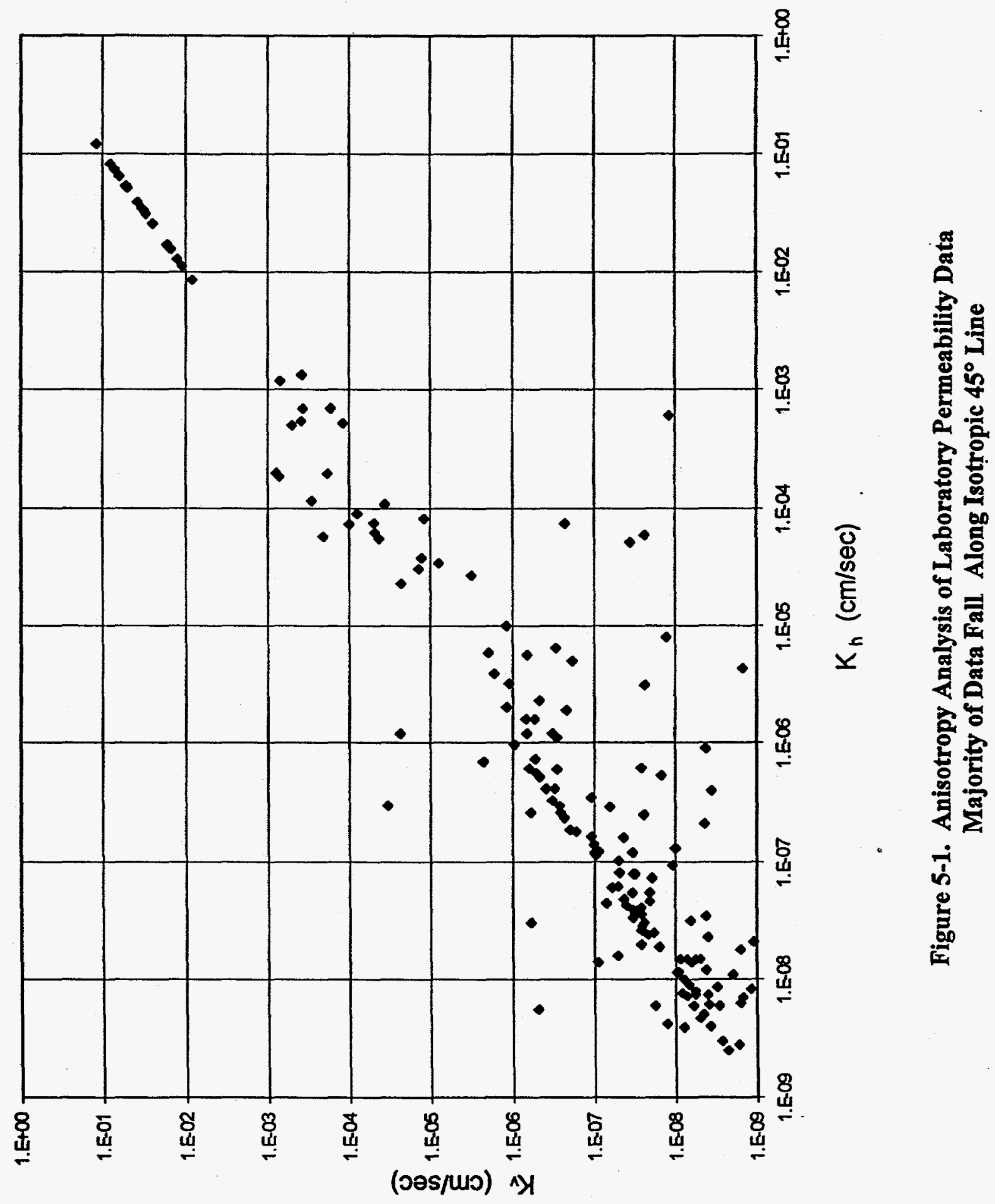




\section{THIS PAGE INTENTIONALLY LEFT BLANK}




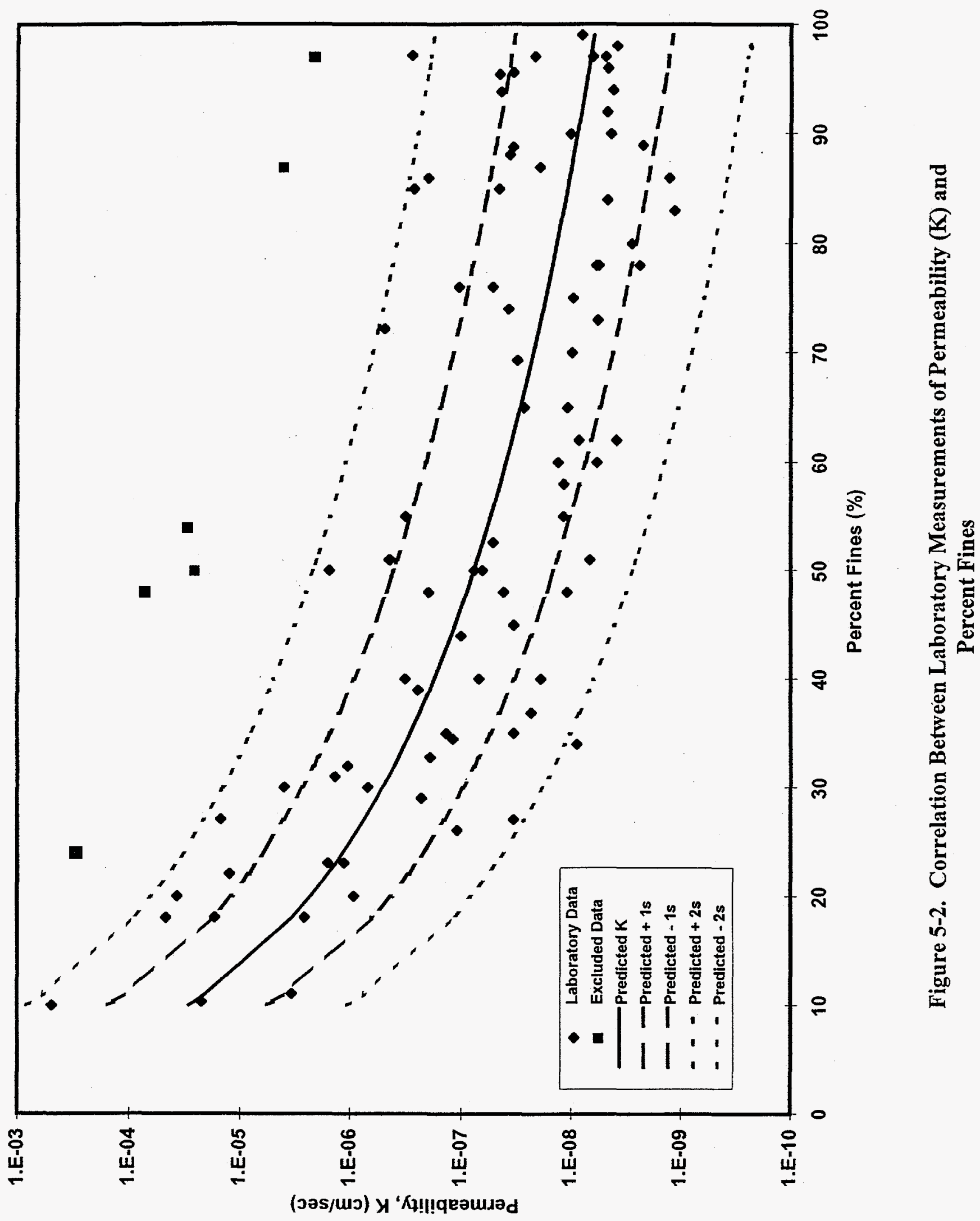




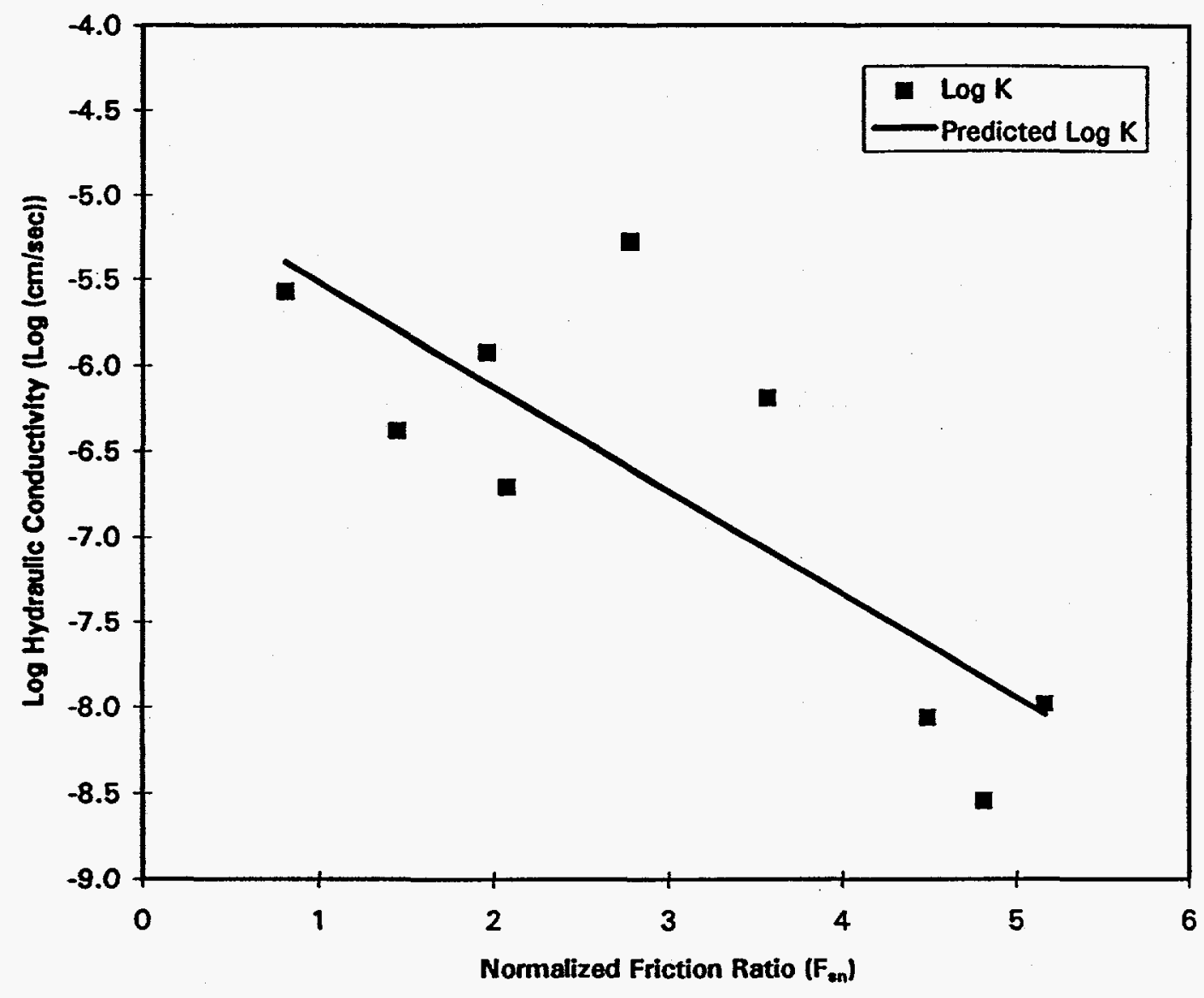

SUMMARY OUTPUT

\begin{tabular}{lc}
\hline \multicolumn{2}{c}{ Regression Statistics } \\
\hline Multiple R & 0.804 \\
R Square & 0.647 \\
Adjusted R Sq & 0.597 \\
Standard Error & 0.751 \\
Observations & 9.000 \\
\hline
\end{tabular}

ANOVA

\begin{tabular}{lrrrrr}
\hline & df & \multicolumn{1}{c}{ SS } & MS & F & Significance $F$ \\
\hline Regression & 1.000 & 7.237 & 7.237 & 12.830 & 0.009 \\
Residual & 7.000 & 3.949 & 0.564 & & \\
Total & 8.000 & 11.186 & & & \\
\hline
\end{tabular}

\begin{tabular}{lrrrrrr}
\hline & Coefficients & Standard Error & \multicolumn{1}{c}{$t$ Stat } & P-value & Lower 95\% & Upper 95\% \\
\hline Intercept & -4.909 & 0.568 & -8.636 & 0.000 & -6.253 & -3.565 \\
X Variable 1 & -0.606 & 0.169 & -3.582 & 0.009 & -1.006 & -0.206 \\
\hline
\end{tabular}

Figure 5-3. Regression Analysis of Hydraulic Conductivity and Normalized Friction Ratio Results from Burial Ground Data 


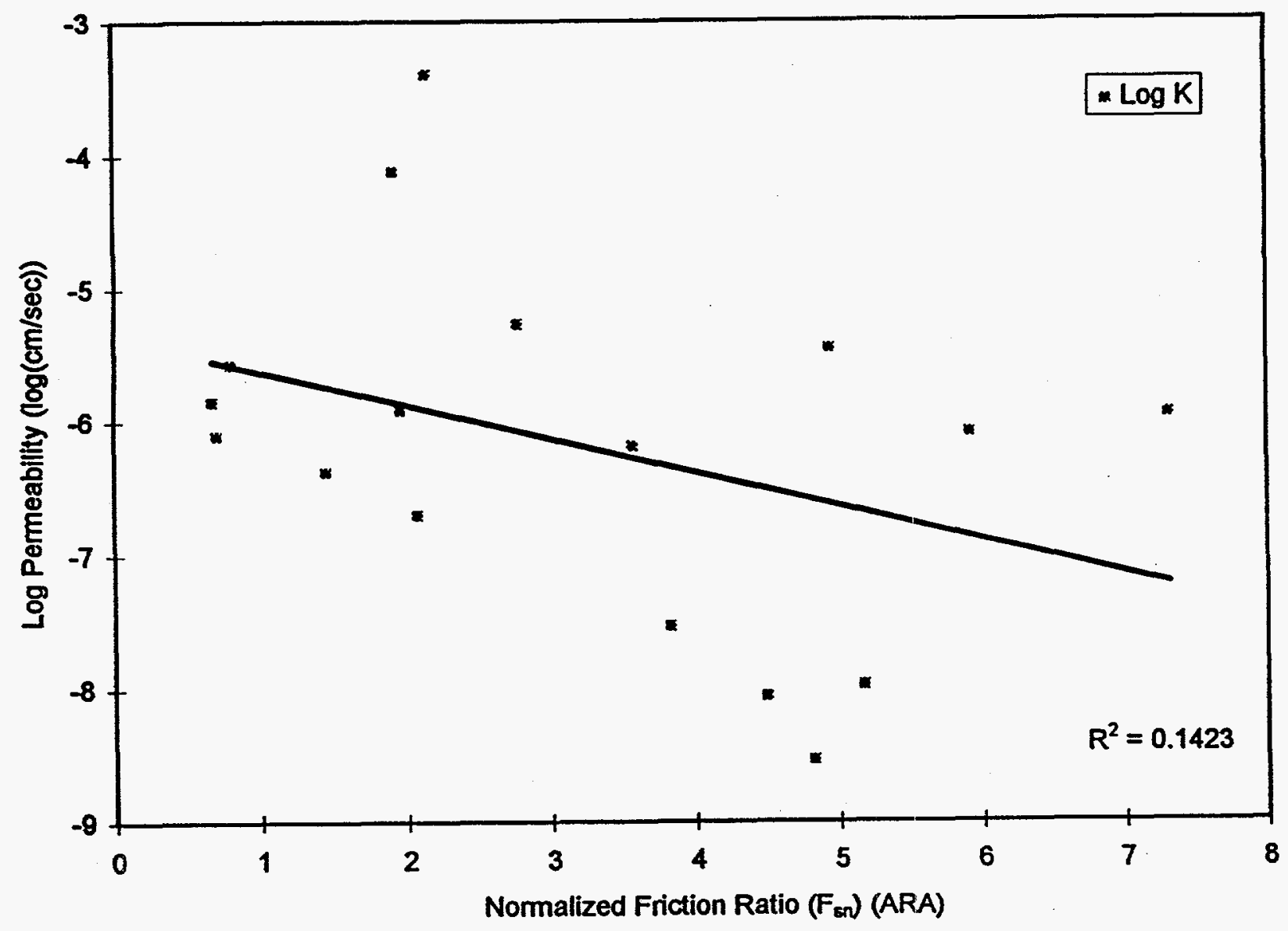

Figure 5-4. Regression Analysis of Hydraulic Conductivity and Normalized Friction Ratio Results from Fugro Burial Ground and ARA R-Area Data 


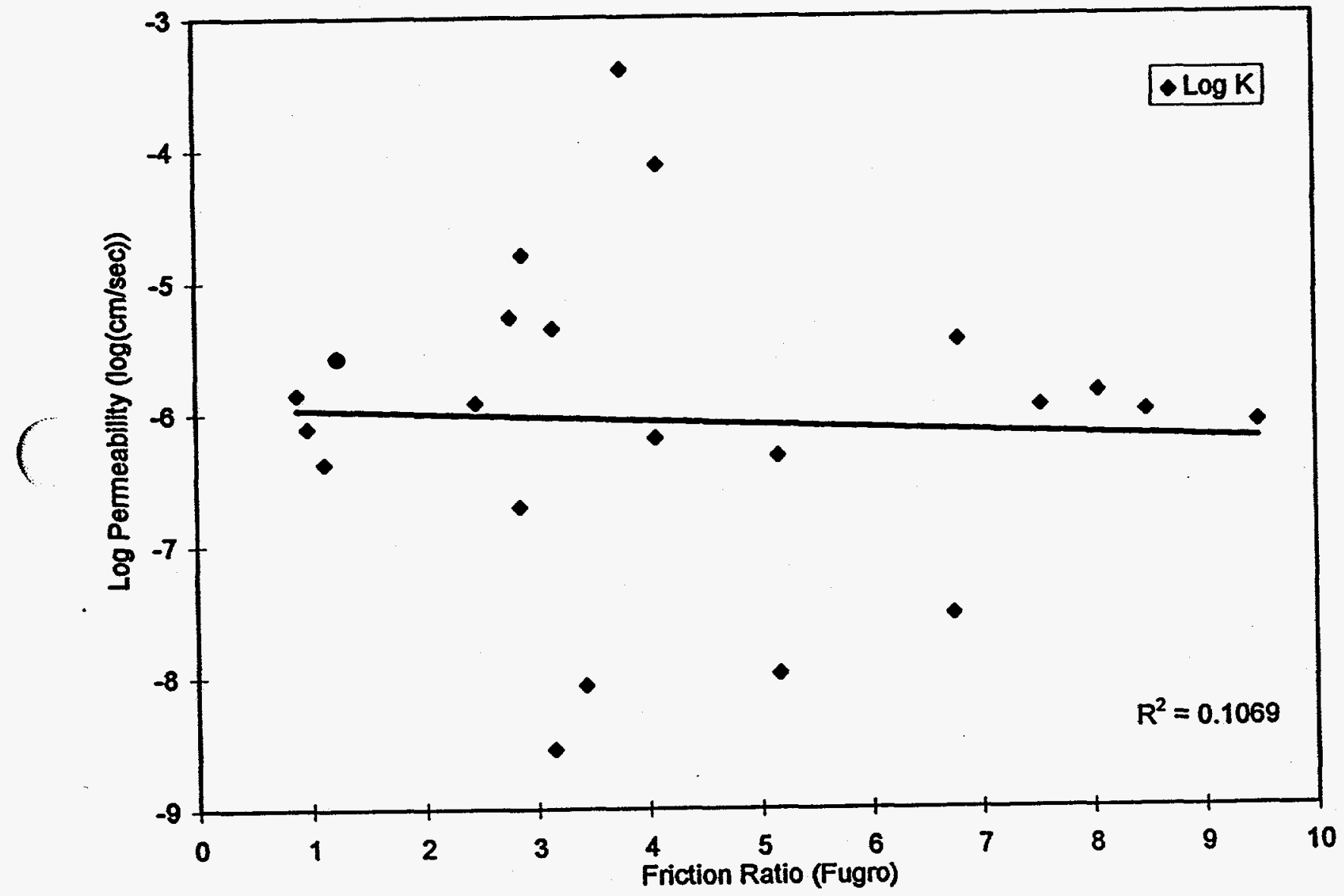

Figure 5-5. Regression Analysis of Hydraulic Conductivity and Friction Ratio Results from Fugro Burial Ground and R-Area Data 


\section{THIS PAGE INTENTIONALLY LEFT BLANK}




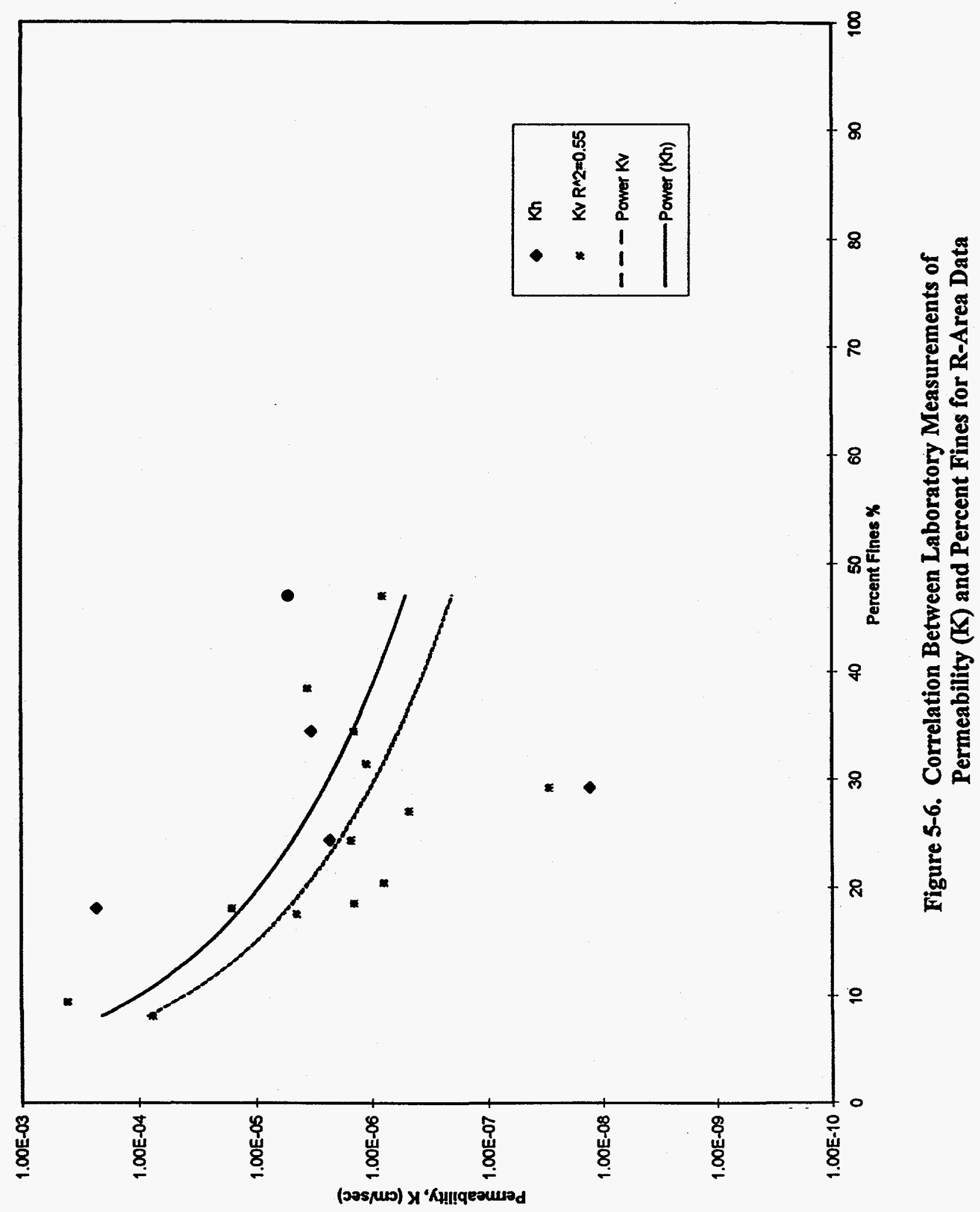




\section{THIS PAGE INTENTIONALLY LEFT BLANK}




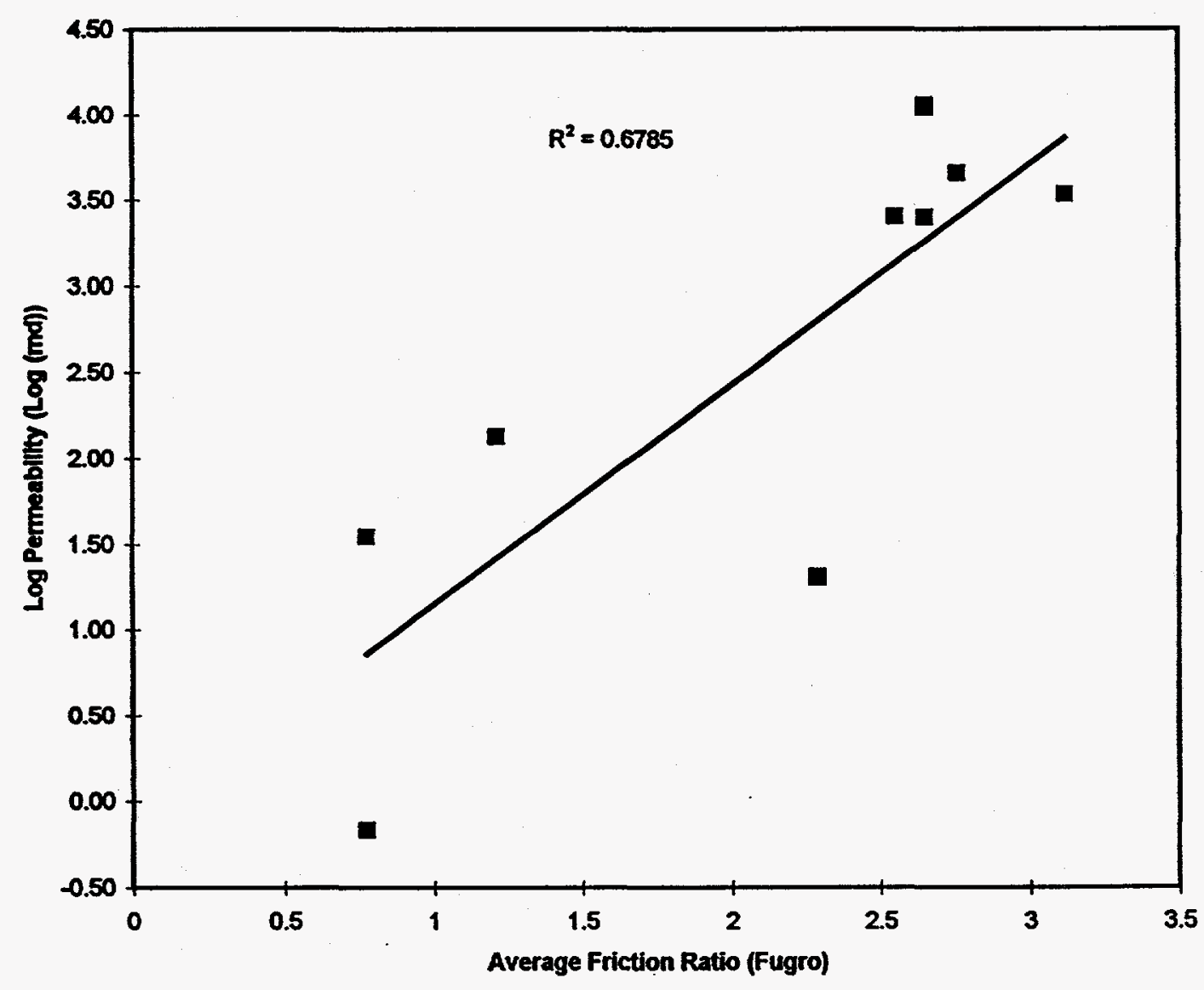

Figure 5-7. Regression Analysis of Air Hydraulic Conductivity and Friction Ratio Results from Fugro Burial Ground Data 


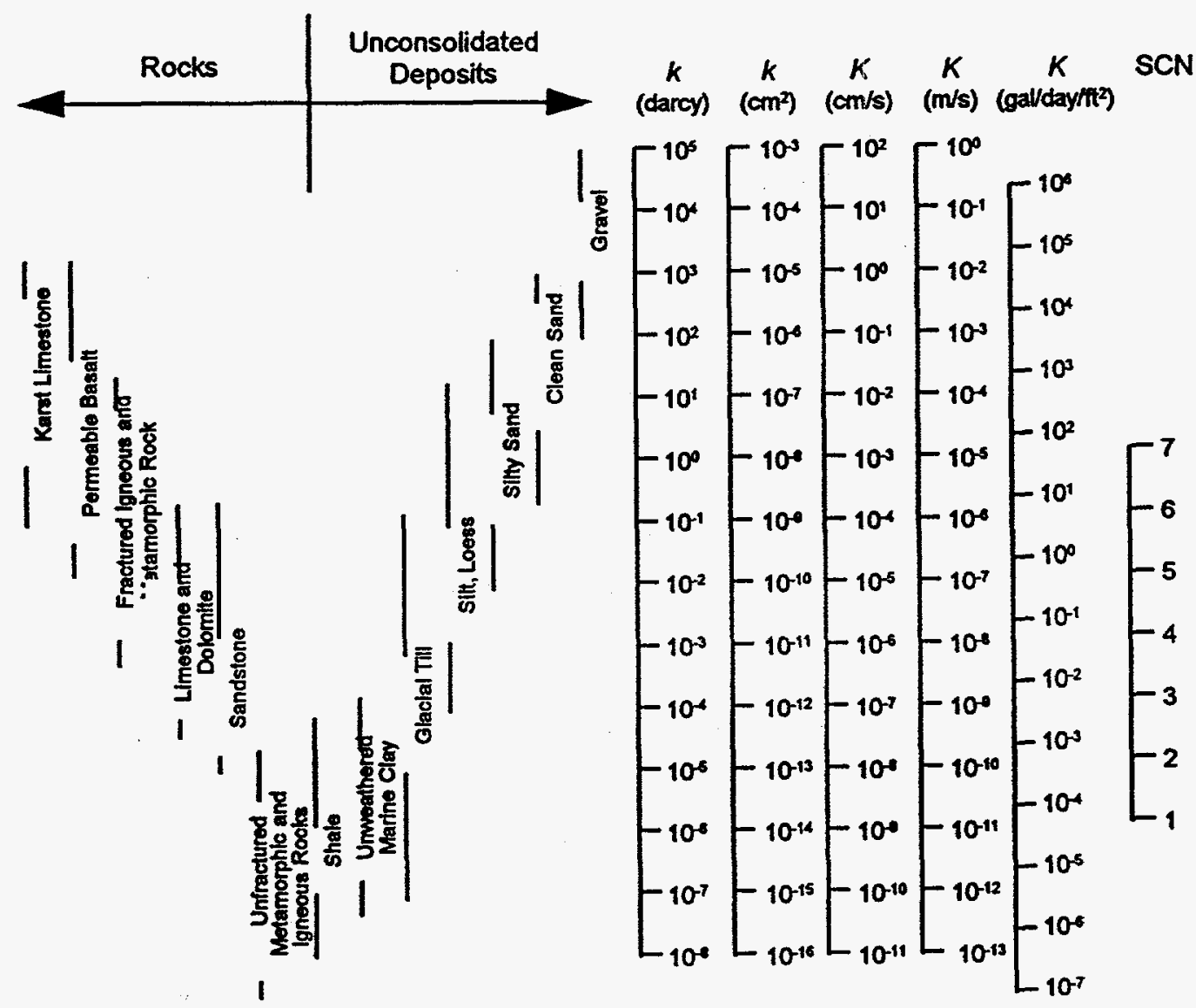

Figure 5-8. Chart Relating Soil Type to Hydraulic Conductivity (K) with the CPT Soil Classification Number (SCN) Superimposed (from Freeze and Cherry 1979) 
RCH-1 APPLIED RESEARCH ASSOCIATES, INC.
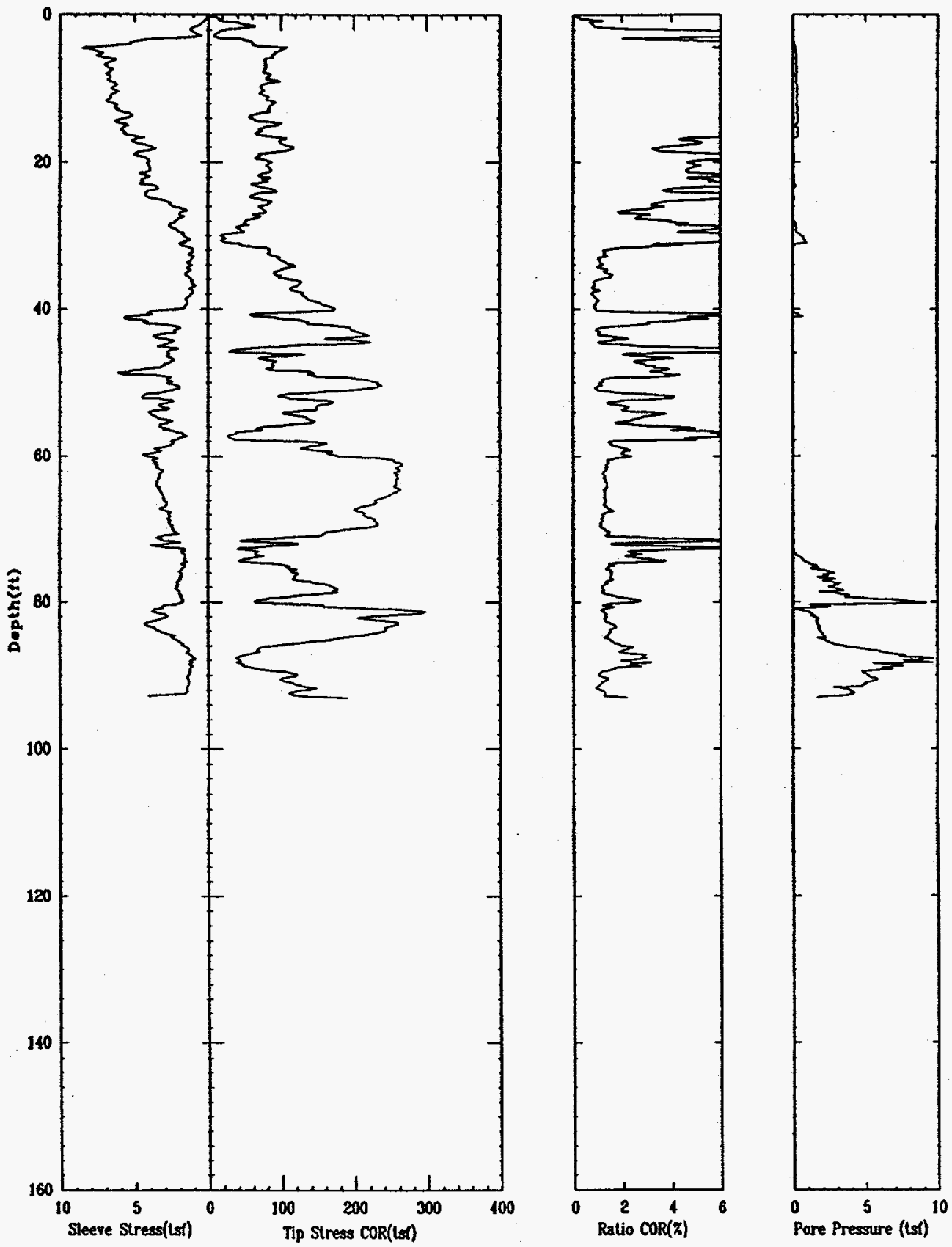

Tite RCH.BCP

Figure 5-9. CPT Data From Location RCH-1 Along with Hydraulic Conductivity Estimates Using Both the Soil Classification Procedure, Friction Ratio Correlation, and Laboratory Hydraulic Conductivity Results 
APPLIED RESEARCH ASSOCIATES, INC.
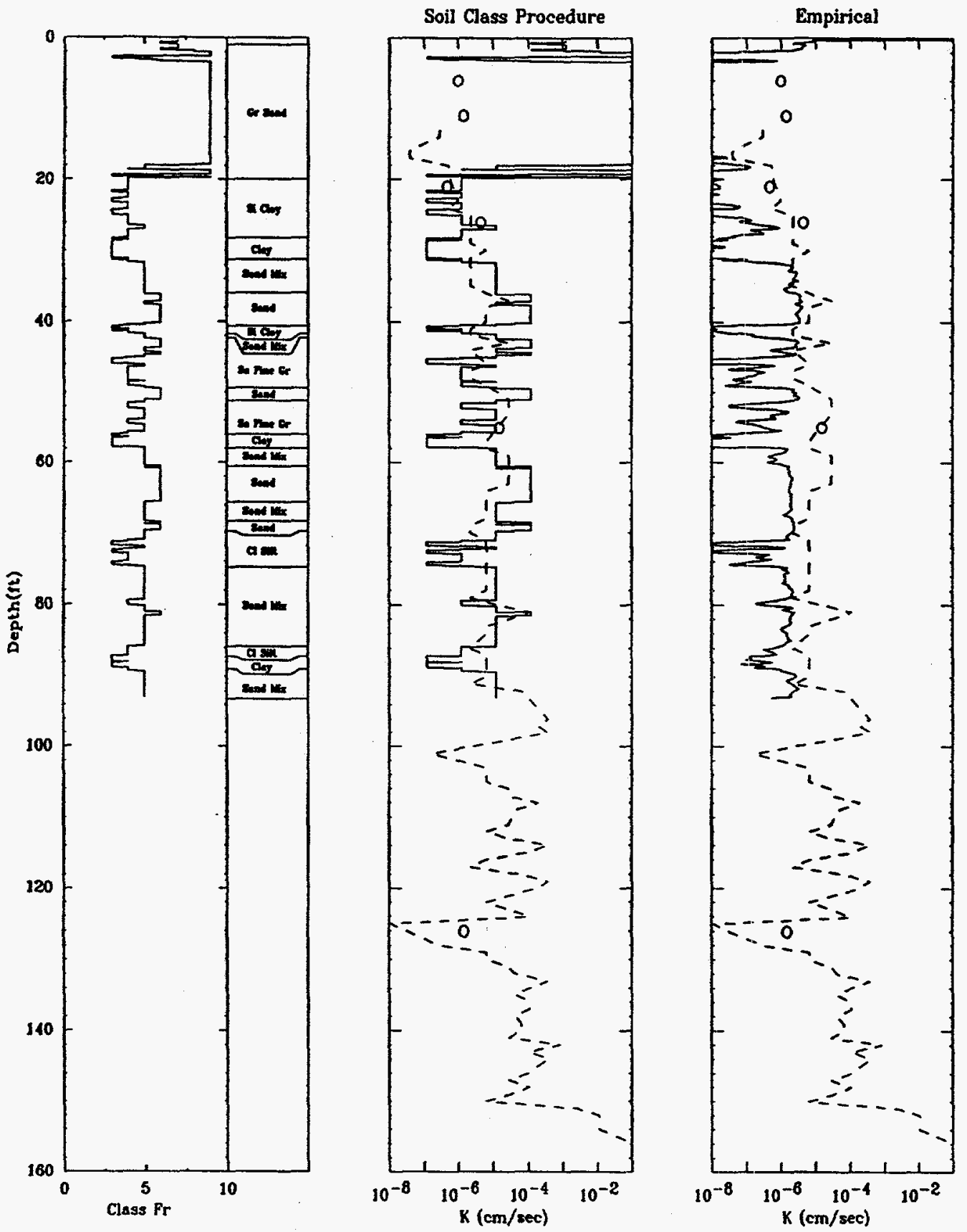

Pile RCH1.DCP

Figure 5-9. CPT Data from Location RCH-1 Along with Hydraulic Conductivity Estimates Using Both the Soil Classification Procedure, Friction Ratio Correlation, and Laboratory Hydraulic Conductivity Results (continued) 
RPC-2

APPLIED RESEARCH ASSOCIATES, INC.
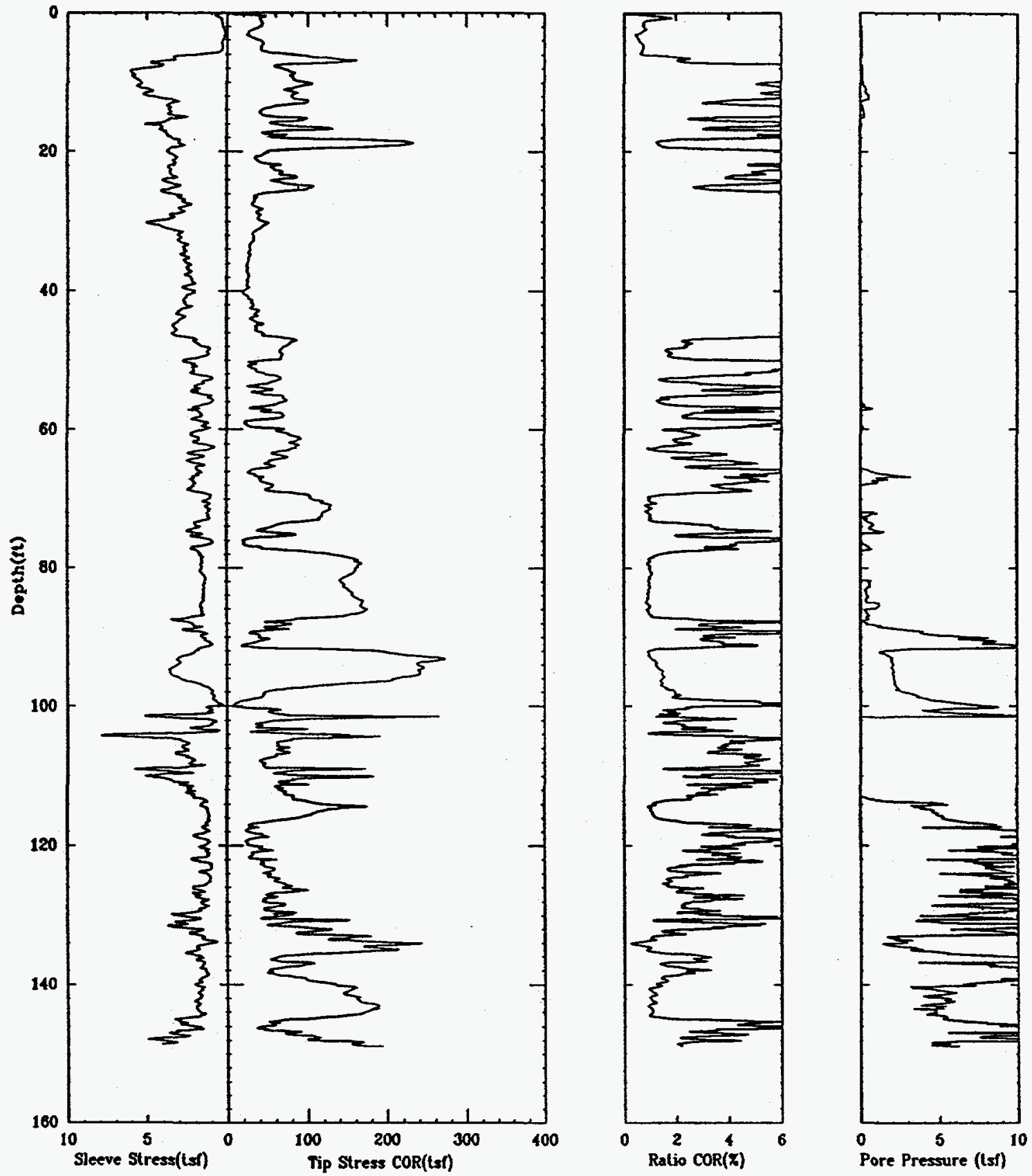

Nile RPC2.ECP

Figure 5-10. CPT Data from Location RPC-2 Along with Hydraulic Conductivity Estimates Using Both the Soil Classification Procedure, Friction Ratio Correlation, and Laboratory Hydraulic Conductivity Results 
$\mathrm{RPC}-2$

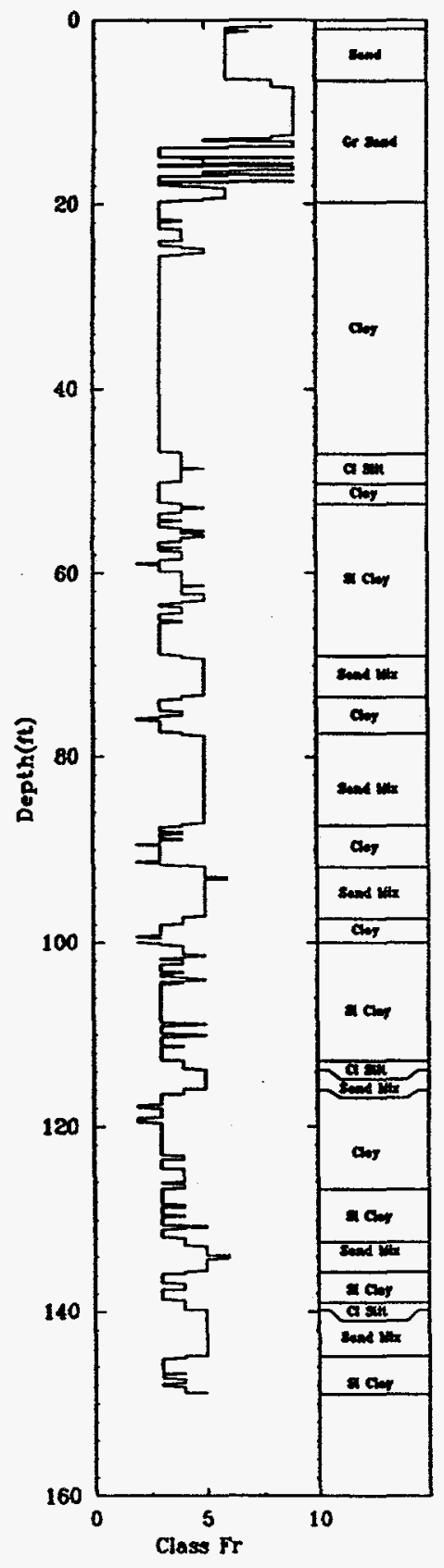

APPLIED RESEARCH ASSOCIATES, INC.

Soil Class Pracedure

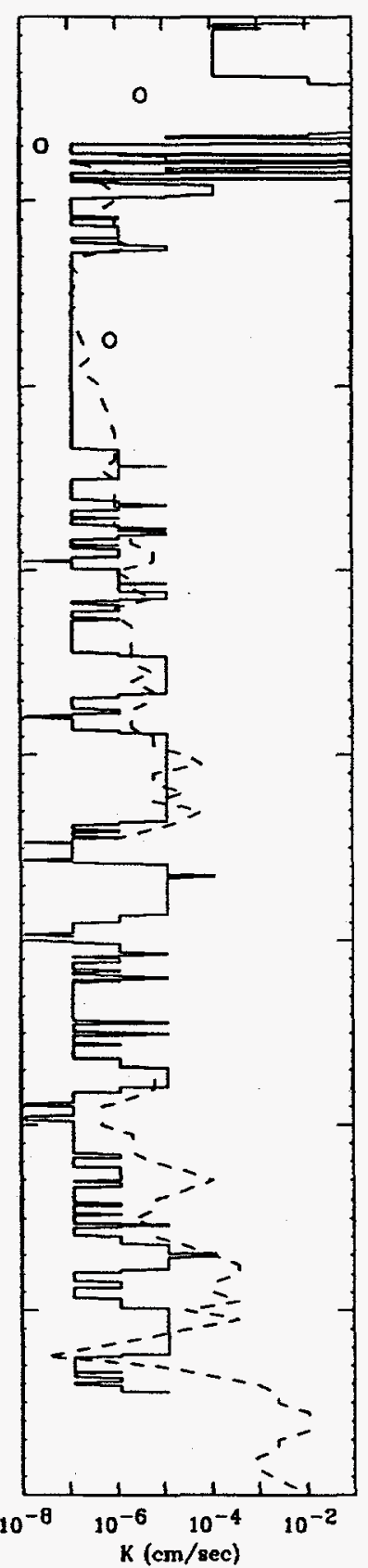

Empirical

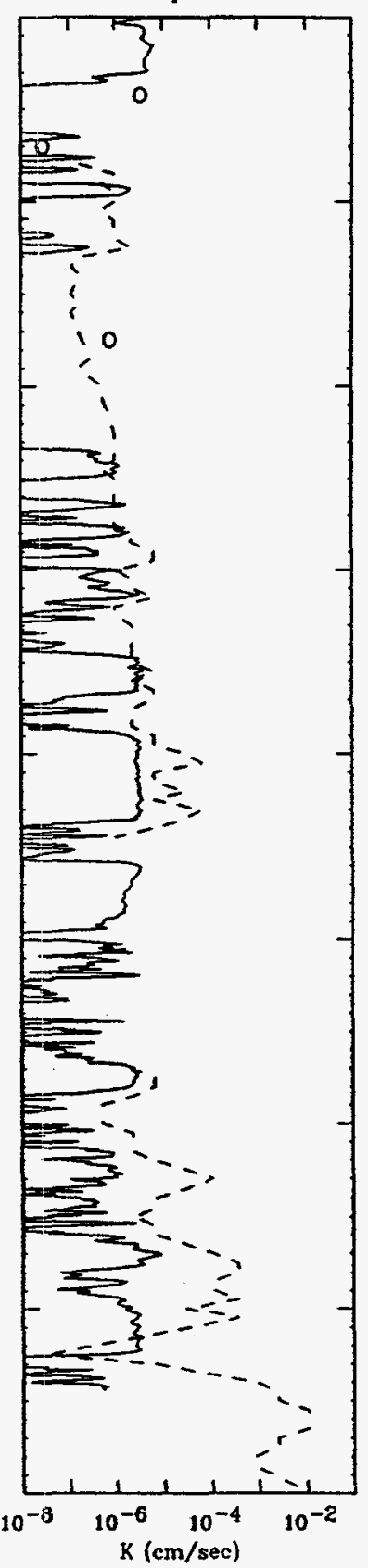

Fle RPCZ.ECP

Figure 5-10. CPT Data from Location RPC-2 Along with Hydraulic Conductivity Estimates Using Both the Soil Classification Procedure, Friction Ratio Correlation and Laboratory Hydraulic Conductivity Results (continued) 
APPLIED RESEARCH ASSOCIATES, INC.
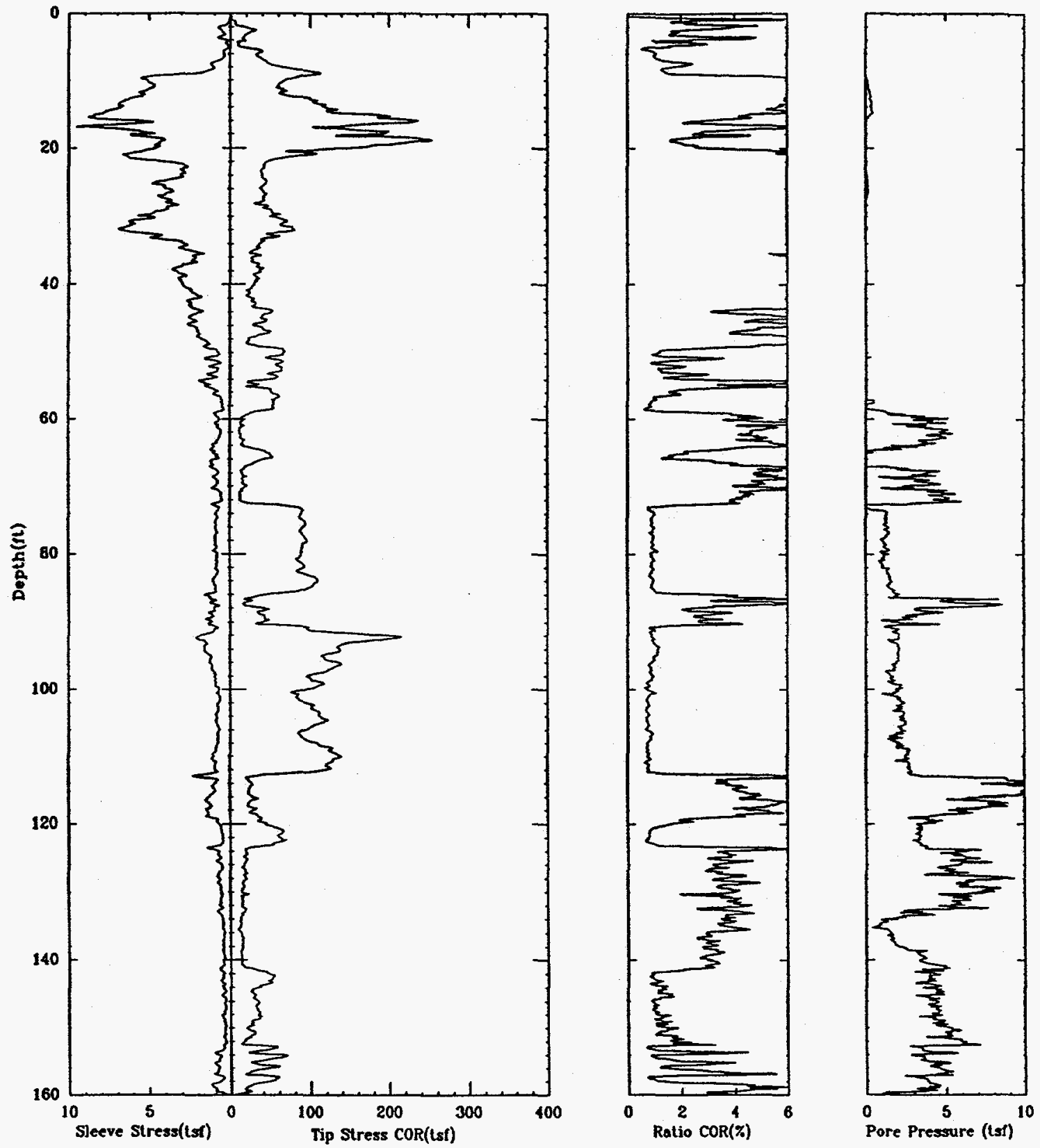

File RPC1.ECP

Figure 5-11. CPT Data from Location RPC-1 Along with Hydraulic Conductivity Estimates Using Both the Soil Classification Procedure, Friction Ratio Correlation and Laboratory Hydraulic Conductivity Results 


\section{$\mathrm{RPC}-1$}

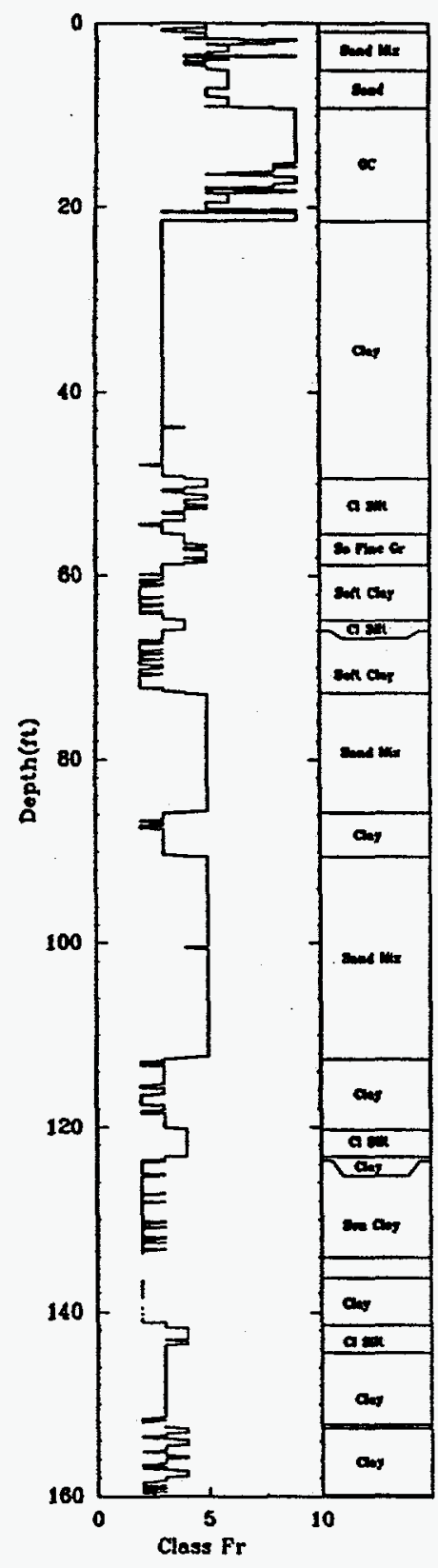

APPLIED RESEARCH ASSOCIATES. INC.

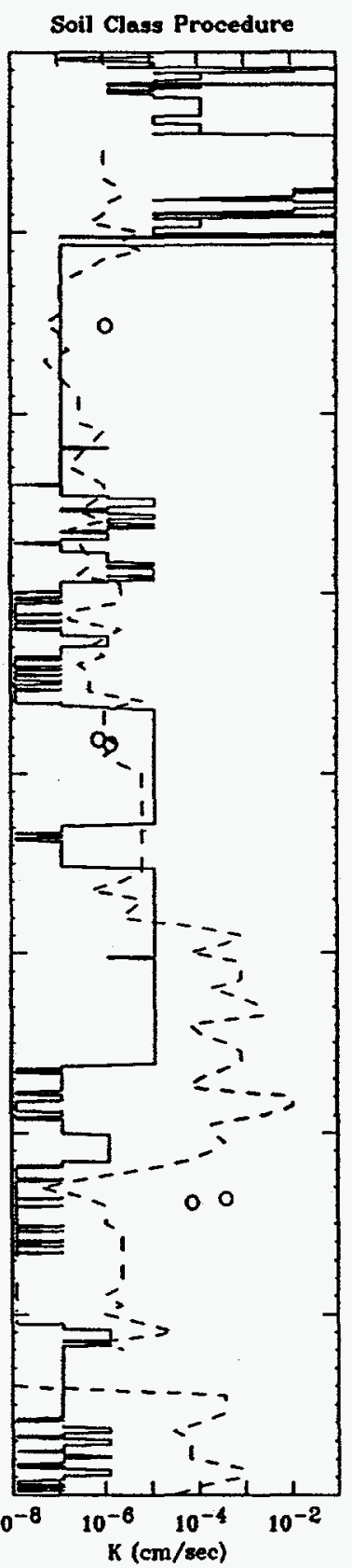

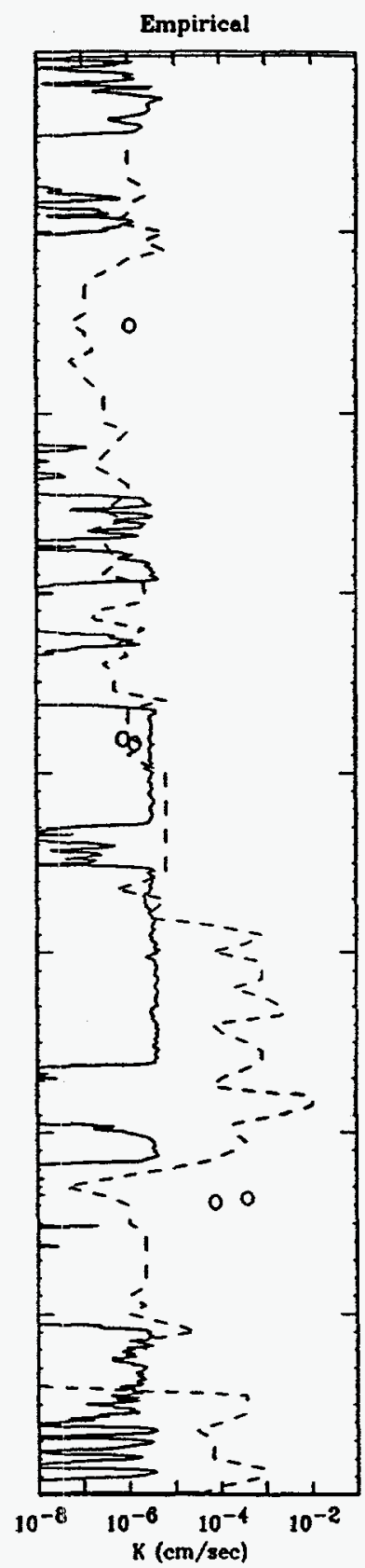

Nite RPC1.RCP

Figure 5-11. CPT Data from Location RPC-1 Along with Hydraulic Conductivity Estimates Using Both the Soil Classification Procedure, Friction Ratio Correlation and Laboratory Hydraulic Conductivity Results (continued) 


\section{SECTION 5}

\section{TABLES}




\section{THIS PAGE INTENTIONALLY LEFT BLANK}


Table 5-1. R-Area Permeabilities With Laboratory, Core, and CPT Data

\begin{tabular}{|c|c|c|c|c|c|c|c|c|c|c|c|c|c|}
\hline Well & Interval (it) & $\begin{array}{c}\mathrm{Kh} \\
(\mathrm{cm} / \mathrm{sec})\end{array}$ & $\log K h$ & $\begin{array}{c}\mathrm{Kv} \\
(\mathrm{cm} / \mathrm{sec})\end{array}$ & $\log K v$ & $\begin{array}{l}\text { Lab \% } \\
\text { Fines } \\
\end{array}$ & Uscs & $\begin{array}{c}\text { Core \% } \\
\text { Fines }\end{array}$ & $\begin{array}{c}\text { Core } \\
\text { Description }\end{array}$ & $\begin{array}{l}\text { ARA CPT- } \\
\text { Fan (avg) }\end{array}$ & $\begin{array}{c}\text { ARA CPT } \\
\text { Bethavior Type }\end{array}$ & \begin{tabular}{|c} 
Fugro CPT- \\
FR (avg) \\
\end{tabular} & $\begin{array}{c}\text { Fugro CPT } \\
\text { Behavior Type }\end{array}$ \\
\hline $\mathrm{RCH}-1$ & $\begin{array}{c}5.7 \\
10-12 \\
20-22 \\
25-27 \\
54.56 \\
125-127\end{array}$ & $\begin{array}{c}\cdot \\
3.30 E-06 \\
\cdot \\
\cdot \\
2.30 E-04 \\
2.30 E-06\end{array}$ & $\begin{array}{c}\cdot \\
-5.48 E+\infty \\
- \\
- \\
-3.64 E+\infty \\
-5.64 E+\infty\end{array}$ & $\begin{array}{l}9.90 E-07 \\
1.40 E-06 \\
4.70 E-07 \\
4.40 E-06 \\
1.60 E-05 \\
1.50 E-06\end{array}$ & $\begin{array}{l}-6.00 E+\infty \\
-5.85 E+\infty \\
-6.33 E+\infty \\
-5.36 E+\infty \\
-4.80 E+\infty \\
-5.82 E+\infty\end{array}$ & $\begin{array}{l}50.2 \\
34.5 \\
27.1 \\
17.6 \\
18.1 \\
24.4\end{array}$ & $\begin{array}{l}\mathrm{CL} \\
\mathrm{SC} \\
\mathrm{SC} \\
\mathrm{SC} \\
\mathrm{SM} \\
\mathrm{SC}\end{array}$ & $\begin{array}{c}\cdot \\
\cdot \\
\text { NR } \\
\text { NR } \\
\text { NR } \\
\text { NR }\end{array}$ & $\begin{array}{c}- \\
- \\
N R \\
N R \\
N R \\
\text { NR }\end{array}$ & $\begin{array}{l}\cdot \\
. \\
. \\
. \\
. \\
.\end{array}$ & $\begin{array}{l}\cdot \\
\cdot \\
\cdot \\
. \\
. \\
.\end{array}$ & $\begin{array}{l}8.49 \\
8.06 \\
5.17 \\
3.17 \\
2.9 \\
\end{array}$ & $\begin{array}{c}\text { Clays } \\
\text { Clays } \\
\text { Clayey Silt \& } \\
\text { Sitty Clayshlays } \\
\text { Sandy Sin \& } \\
\text { Siltsilty Sand } \\
\text { Siny } \\
\text { Sand/Sandy Sin } \\
.\end{array}$ \\
\hline $\begin{array}{r}(S T-1) \\
\text { (ST-2) } \\
\end{array}$ & $\begin{array}{c}30 \cdot 30.5 \\
76 \cdot 76.5 \\
76.5-77 \\
127 \cdot 127.5 \\
127.5 \cdot 128 \\
145-147 \\
11.5 \cdot 213 . \\
\end{array}$ & $\begin{array}{l}- \\
\cdot \\
- \\
\cdot \\
\cdot \\
\cdot \\
.\end{array}$ & $\begin{array}{l}\cdot \\
\cdot \\
\cdot \\
\cdot \\
- \\
.\end{array}$ & $\begin{array}{l}1.10 E-06 \\
7.80 E-07 \\
1.40 E-06 \\
4.00 E-04 \\
7.60 E-05 \\
6.50 E-07 \\
1.40 E-07\end{array}$ & $\begin{array}{l}-5.96 E+\infty \\
-6.11 E+\infty \\
-5.85 E+\infty \\
-3.40 E+\infty \\
-4.12 E+\infty \\
-4.12 E+\infty \\
-4.12 E+\infty\end{array}$ & $\begin{array}{l}31.5 \\
20.5 \\
18.6 \\
9.4 \\
8.1 \\
11 \\
97 \\
\end{array}$ & $\begin{array}{c}\text { SM } \\
- \\
\text { SM } \\
\text { SP-SM } \\
\text { SP-SM } \\
\text { SP-SM } \\
\text { ML } \\
\end{array}$ & $\begin{array}{l}45 \\
20 \\
20 \\
25 \\
25 \\
\text { NR } \\
\text { NR }\end{array}$ & $\begin{array}{l}\text { CLSD } \\
\text { SAND } \\
\text { SAND } \\
\text { CLSD } \\
\text { CLSD } \\
\text { NR } \\
\text { NR } \\
\end{array}$ & $\begin{array}{l}7.31 \\
0.71 \\
0.68 \\
2.16 \\
1.93 \\
0.54 \\
- \\
\end{array}$ & $\begin{array}{l}\text { Sandy Clay } \\
\text { Clayey Sand } \\
\text { Clayey Sand } \\
\text { Organica-Peat } \\
\text { Organica-Peat } \\
\text { Sandy Clay }\end{array}$ & $\begin{array}{c}7.55 \\
0.985 \\
0.896 \\
3.8 \\
4.11 \\
1.13 \\
.\end{array}$ & $\begin{array}{c}\text { Clays } \\
\text { Sands } \\
\text { Sands } \\
\text { Clayey Sith \& } \\
\text { Siliy Clays } \\
\text { Claysiclayey Siti } \\
\text { \& Silty Clays } \\
\text { Silty } \\
\text { Sand/Sandy Sin } \\
\text {. }\end{array}$ \\
\hline RPC-2C & $\begin{array}{c}8-9 \\
13-15 \\
34-36\end{array}$ & $\begin{array}{c}\cdot \\
1.30 E-08 \\
5.20 E-06\end{array}$ & $\begin{array}{c}- \\
-7.89 E+\infty \\
-5.28 E+\infty 0\end{array}$ & $\begin{array}{l}3.50 E-06 \\
2.90 E-08 \\
8.00 E-07\end{array}$ & \begin{tabular}{|}
$-5.46 E+\infty$ \\
$-7.54 E+\infty$ \\
$-6.10 E+\infty 0$
\end{tabular} \mid & $\begin{array}{l}38.5 \\
29.3 \\
47.1\end{array}$ & $\begin{array}{l}\mathrm{sc} \\
\mathrm{sc} \\
\mathrm{sc}\end{array}$ & $\begin{array}{c}\cdot \\
\cdot \\
\text { NR }\end{array}$ & $\begin{array}{c}\cdot \\
\text { NR }\end{array}$ & $\begin{array}{l}4.95 \\
3.83 \\
5.92\end{array}$ & $\begin{array}{l}\text { Sand/Sandy } \\
\text { Clay } \\
\text { Sand/Sandy } \\
\text { Clay } \\
\text { Sandy Clay }\end{array}$ & $\begin{array}{l}6.81 \\
6.75 \\
9.49\end{array}$ & $\begin{array}{c}\text { Clays } \\
\text { Claysiclayey Sin } \\
\text { \& Siny Clays } \\
\text { Clays }\end{array}$ \\
\hline
\end{tabular}


Table 5-2. Burial Ground Air Permeabilities With Laboratory, Core, and CPT Data

\begin{tabular}{|c|c|c|c|c|c|c|c|c|c|c|c|}
\hline Well & Interval (ft) & $\begin{array}{l}\text { Kh-air } \\
\text { (md) }\end{array}$ & $\log K h$ & $\begin{array}{l}\text { Kv-air } \\
\text { (md) }\end{array}$ & $\log K v$ & $\begin{array}{c}\text { Porosity } \\
(\%)\end{array}$ & Lab Description & $\begin{array}{c}\text { Core } \% \\
\text { Fines }\end{array}$ & $\begin{array}{c}\text { Core } \\
\text { Description }\end{array}$ & $\begin{array}{c}\text { Fugro CPT- } \\
\text { FR (avg) }\end{array}$ & $\begin{array}{c}\text { Fugro CPT } \\
\text { Behavior Type }\end{array}$ \\
\hline \multirow[t]{3}{*}{ OFS-2SB } & $|108.0-108.3|$ & 20.3 & $1.31 E+00$ & - & - & 47.0 & $\begin{array}{l}\text { Consolidated } \\
\text { micritic sand }\end{array}$ & 10 & $\begin{array}{c}\text { Micritic } \\
\text { calcarenitic } \\
\text { sand } \\
\end{array}$ & 2.29 & $\begin{array}{c}\text { Sands/slity } \\
\text { sand/sandy silt } \\
\& \text { silt }\end{array}$ \\
\hline & $114.0-114.2$ & 0.681 & $-1.67 E-01$ & & & 19.5 & $\begin{array}{l}\text { Consolidated } \\
\text { micritic sand }\end{array}$ & 5 & $\begin{array}{c}\text { Micritic } \\
\text { sand }\end{array}$ & 0.772 & $\begin{array}{c}\text { Silty } \\
\text { sand/sands }\end{array}$ \\
\hline & $114.0-114.2$ & & & 3.50E+01 & $1.54 E+00$ & 29.5 & $\begin{array}{l}\text { Consolidated } \\
\text { micritic sand }\end{array}$ & 5 & $\begin{array}{l}\text { Micritic } \\
\text { sand }\end{array}$ & 0.772 & $\begin{array}{c}\text { Silty } \\
\text { sand/sands }\end{array}$ \\
\hline \multirow[t]{5}{*}{ OFS-4SB } & $25.2-25.5$ & 2522 & $3.40 E+00$ & - & - & 31.5 & $\begin{array}{c}\text { Unconsolidated } \\
\text { sand }\end{array}$ & 5 & Sand & 2.55 & Sitty sand \\
\hline & $47.5-47.8$ & 3410 & $3.53 E+00$ & - & - & 31.4 & $\begin{array}{c}\text { Slightly } \\
\text { consolidated } \\
\text { clayey sand }\end{array}$ & 2 & Sand & 3.12 & $\begin{array}{c}\text { Clayey silt \& } \\
\text { silty clays/sandy } \\
\text { silt \& silt }\end{array}$ \\
\hline & $56.0-56.3$ & 2490 & $3.40 E+00$ & & & 36.8 & $\begin{array}{l}\text { Unconsolidated } \\
\text { clayey sand }\end{array}$ & 30 & $\begin{array}{l}\text { Clayey } \\
\text { sand }\end{array}$ & 2.65 & $\begin{array}{c}\text { Sandy silt \& } \\
\text { siltclayey silt \& } \\
\text { silty clays }\end{array}$ \\
\hline & $56.0 \cdot 56.3$ & & & $1.14 E+04$ & $4.06 E+00$ & 42.2 & $\begin{array}{l}\text { Unconsolidated } \\
\text { clayey sand } \\
\text { (fracture } \\
\text { sample) }\end{array}$ & 30 & $\begin{array}{l}\text { Clayey } \\
\text { sand }\end{array}$ & 2.65 & $\begin{array}{c}\text { Sandy silt \& } \\
\text { silt/clayey silt \& } \\
\text { silty clays }\end{array}$ \\
\hline & $78.0-78.4$ & 134 & $2.13 E+00$ & - & - & 27.2 & $\begin{array}{l}\text { Unconsolidated } \\
\text { micritic sand }\end{array}$ & 5 & $\begin{array}{l}\text { Micritic } \\
\text { sand }\end{array}$ & 1.21 & Sands \\
\hline OFS-5SB & $56.5-56.8$ & 4550 & $3.66 \mathrm{E}+00$ & - & - & 38.5 & $\begin{array}{c}\text { Unconsolidated } \\
\text { sand }\end{array}$ & 5 & Sand & 2.76 & Sandy silt \& silt \\
\hline
\end{tabular}


Table 5-3. Comparison of Regression Approach and Soil Classification Number Approach for Estimating Hydraulic Conductivity from CPT Data

\begin{tabular}{|c|c|c|c|c|c|c|c|c|}
\hline \multirow{2}{*}{$\begin{array}{l}\text { Boring } \\
\text { ID }\end{array}$} & \multirow{2}{*}{$\begin{array}{l}\text { Int } \\
\text { Top } \\
\text { (ft) }\end{array}$} & \multirow{2}{*}{$\begin{array}{l}\text { Int } \\
\text { Bot } \\
\text { (ft) }\end{array}$} & \multirow{2}{*}{$\begin{array}{l}\text { Laboratory } \\
\text { Log K } \\
\text { (cm/sec) }\end{array}$} & \multicolumn{2}{|c|}{$F_{\text {en }}$ Regression } & \multicolumn{3}{|c|}{ Soil Classification Approach } \\
\hline & & & & $\begin{array}{c}\text { Calculated Log } \\
\text { K }\end{array}$ & $\%$ Error & SCN & $\begin{array}{c}\text { Calculated Log } \\
\mathrm{K}\end{array}$ & $\%$ Error \\
\hline $\begin{array}{l}\text { BGT009 } \\
\text { BGT011 } \\
\text { BGT053 } \\
\text { BGT061 } \\
\text { BGT061 } \\
\text { BGT067 } \\
\text { OFS001SB } \\
\text { OFS003SB } \\
\text { OFS004SB } \\
\text { OFS005SB } \\
\text { RCH1.prn } \\
\text { RPC1.prn } \\
\text { RPC1.prn } \\
\text { RPC1.prn } \\
\text { RPC1.prn }\end{array}$ & $\begin{array}{r}72 \\
70 \\
88 \\
102 \\
178 \\
57 \\
67 \\
63 \\
45 \\
27 \\
54 \\
76 \\
76.5 \\
127 \\
127.5\end{array}$ & $\begin{array}{r}73.5 \\
71 \\
90 \\
104 \\
179.1 \\
59 \\
68.7 \\
65 \\
47 \\
28.9 \\
56 \\
76.5 \\
77 \\
127.5 \\
128\end{array}$ & $\begin{array}{l}-6.38 \\
-6.71 \\
-7.98 \\
-8.06 \\
-8.55 \\
-5.27 \\
-5.57 \\
-5.92 \\
-6.19 \\
-3.30 \\
-4.22 \\
-6.11 \\
-5.85 \\
-3.40 \\
-4.12\end{array}$ & $\begin{array}{l}-5.79 \\
-6.17 \\
-8.04 \\
-7.63 \\
-7.83 \\
-6.60 \\
-5.40 \\
-6.10 \\
-7.07 \\
-5.99 \\
-6.62 \\
-5.53 \\
-5.49 \\
-7.67 \\
-8.28\end{array}$ & $\begin{array}{c}9.3 \% \\
8.1 \% \\
0.8 \% \\
5.3 \% \\
8.4 \% \\
25.2 \% \\
3.0 \% \\
3.1 \% \\
14.3 \% \\
81.6 \% \\
57.0 \% \\
9.4 \% \\
6.3 \% \\
125.7 \% \\
101.1 \%\end{array}$ & $\begin{array}{l}6 \\
5 \\
3 \\
3 \\
3 \\
3 \\
5 \\
4 \\
3 \\
5 \\
5 \\
5 \\
5 \\
3 \\
3\end{array}$ & $\begin{array}{l}-3.91 \\
-4.91 \\
-6.91 \\
-6.91 \\
-6.91 \\
-6.91 \\
-4.91 \\
-5.91 \\
-6.91 \\
-4.91 \\
-4.91 \\
-4.91 \\
-4.91 \\
-6.91 \\
-6.91\end{array}$ & $\begin{array}{c}38.7 \% \\
26.8 \% \\
13.4 \% \\
14.3 \% \\
19.2 \% \\
31.1 \% \\
11.8 \% \\
0.2 \% \\
11.6 \% \\
48.8 \% \\
16.4 \% \\
19.6 \% \\
16.1 \% \\
103.4 \% \\
67.8 \%\end{array}$ \\
\hline & & & & \multicolumn{3}{|c|}{ Average $30.6 \%$} & \multicolumn{2}{|l|}{ Average } \\
\hline
\end{tabular}




\subsection{CONCLUSIONS AND RECOMMENDATIONS}

This section summarizes the results and describes conclusions and recommendations based upon the analyses performed during the study presented herein.

\subsection{Conclusions}

The objectives of this study were to develop site-specific correlations between CPT and core descriptions and to develop a CPT-permeability curve. An analysis of the core data was performed along with a comparison to CPT-generated profiles. Differences were noted that should be investigated further. Using the provided data, SCN values of 5 and 6 correspond to the core classification of sand. SCN values of 3 and 4 correspond to a lithologic core description of clayey sand to sandy clay, with 2 and 3 representing clay from the core descriptions. Based upon the data sets provided for this project, there is currently insufficient evidence to change the soil-type boundary curves for SRS soil types from the standard presented in Robertson (1990). However, Region 2 should be redefined as "soft clayey soils," in lieu of its original description as "organic soils."

For the permeability estimates, two different approaches were developed. One approach was based upon the correlation between SCN and permeability (i.e., the soil classification approach) while the second approach was based upon a correlation between normalized friction ratio $\left(F_{s n}\right)$ and permeability (i.e., the $F_{s n}$ regression approach). Both approaches offer reasonable results, with the soil classification approach overpredicting permeability in the gravelly sand materials and the $F_{s n}$ regression approach underpredicting the permeability in the clayey materials. A limited statistical analysis indicates that the $F_{\mathrm{sn}}$ regression approach appears to offer more accurate predictions based upon the limited data set and is, therefore, the recommended procedure at this time. Additional data are needed to both confirm the correlation over a significantly larger data set and extend the boundaries where the analysis is applicable.

Overall, this study provided insight into advanced methods of increasing CPT data utility for the development of valuable site characterization data. Additional studies with larger and more detailed data sets will further increase the utility of the CPT data. 


\subsection{Recommendations}

The analyses performed and presented in this report are based upon a series of assumptions and a rather limited data set. The most significant recommendation is that additional data be gathered and that the analysis be re-evaluated. Directly comparable data are a prerequisite to correctly and consistently correlate CPT, geophysical, and geological logs and, ultimately, to develop a site-specific algorithm to allow CPT to replace some core drilling at the SRS. However, due to the nature of fluvial systems, even a horizontal separation of $5 \mathrm{ft}$ or less can demonstrate significant changes in lithologic facies. Therefore, it is recommended that a statistically significant number of paired CPT-core borings be made across the SRS wherein a 4- to 6-in core is taken within inches of a CPT penetration. Rotasonic core drilling would especially lend itself to such a project, since it yields a relatively undisturbed 5 -in core, produces little waste, and is significantly faster than conventional core drilling techniques.

In addition to the field data, a laboratory study using soils with different fine-grain contents should be prepared and tested using CPT in controlled conditions. Items to be controlled include fine-grain content and horizontal and vertical stress states. From this information, the CPT response to various fine-grain contents and layer interface influences can be determined and evaluated.

The data base of coincident CPT, geophysical, and geological information needs to be expanded to cover all the typical soil materials at the SRS, including both permeable and nonpermeable materials. The types of additional data required are laboratory grain size and hydraulic conductivity tests on very specific core sections that are accurately defined in both location and depth. Additional refinement in the core data is needed to verify existing boundaries and improve correlations. To obtain data for additional refinement, grain size analysis is needed for comparison to CPT data to develop more grain-size classifications for the CPT system. This approach will refine the core descriptions and allow for better soil descriptions. 


\subsection{REFERENCES}

Abramson, L.W., 1994. "Soil Compaction and Consolidation," in Ground Control and Improvement, P.P. Xanthakos, L.W. Abramson, and D.A. Bruce, eds. New York: John Wiley and Sons. p. 234-330.

Applied Research Associates, Inc., 1992a. Piezo-Resistivity Electric Cone Penetration Technology Investigation of the M-Basin at the Savannah River Site, Aiken, South Carolina.

Applied Research Associates, Inc., 1992b. Piezo Electric Cone Penetration Tests in Support of Geotechnical Investigations at Section 1/9 of Fresh Kills Landfill, Staten Island, New York.

ASTM D3441-86, "Standard Test Method for Deep, Quasi-Static, Cone and FrictionCone Penetration Test of Soil." p. 414-419.

Bear, J., 1972. Dynamics of Fluids in Porous Media, Amer. New York: Elsevier.

Campanella, R.G., and P.K. Robertson, 1988. "Current Status of the Piezocone Test," Proc. Penetration Testing 1988, ISOPT-1, DeRuiter, ed. Vol. 1, p. 93-116. Orlando, Florida.

Campanella, R.G., and P.K. Robertson, 1983. "Interpretation of Cone Penetrometer Tests, Part I-Sand, Part II-Clay," Canadian Geotechnical Journal. Vol. 20, No. 4. p. 718-745.

Campanella, R.G., D. Gillespie, and P.K. Robertson, 1982. "State of the Art in In Situ Testing of Soils: Developments since 1978," Engineering Foundation Conference on Updating Subsurface Sampling of Soils and Rocks and their In Situ Testing. ESOPT II. p. 507-512.

Core Laboratories, 1995. Core Analysis Report Savannah River Site: Final Report. Carrollton, Texas: Core Laboratories.

Douglas, B.J., and R.S. Olsen, 1981. "Soil Classification Using the Electric Cone Penetrometer," Proc. Cone Penetration Testing and Experience. p. 209-227. St. Louis, Michigan: ASCE. 
Freeze, R.A., and J.A. Cherry, 1979. Groundwater. Englewood Cliffs, New Jersey: Prentice-Hall, Inc.

GEI Consultants, Inc., 1992. Infiltration Investigation: $K$ Area Cooling Water Reservoir, Savannah River Site, Aiken, South Carolina.

Hazen, A., 1911. Discussion of "Dams on Sand Foundations," by A.C. Koening. Transactions, ASCE. Vol. 73, pp. 199-203.

Holtz, R.D., and W.D. Kovacs, 1981. An Introduction to Geotechnical Engineering. Prentice-Hall, Inc. p. 211.

Jefferies, M.G., and M.P. Davies, 1991. "Soil Classification by the Cone Penetration Test: Discussion," Canadian Geotechnical Journal. 28:173-176.

Law Engineering, Inc., 1996. Test Results dated May 3, 1996; May 21, 1996; and July $12,1996$.

Masch, F.D., and K.J. Denny, 1966. "Grain-Size Distribution and its Effect on the Permeability of Unconsolidated Sands," Water Resources Res. Vol. 2, pp. 665677.

Robertson, P.K., 1990. "Soil Classification using the Cone Penetration Test," Canadian Geotechnical Journal. 27:151-158.

Robertson, P.K., 1991. "Soil Classification by the Cone Penetration Test: Reply," Canadian Geotechnical Journal. 28:176-178.

Robertson, P.K., and R.G. Campanella, 1989. Guidelines for Geotechnical Design Using the Cone Penetrometer Test and CPT with Pore Pressure Measurement, 4th ed.

Robertson, P.K., R.G. Campanella, D. Gillespie, and J.Grieg, 1986. "Use of Piezometer Cone Data," Proceedings, In Situ '86. ASCE Specialty Conference on Use of In Situ Tests in Geotechnical Engineering, Blacksburg, Virginia. ASCE, Geotechnical Special Publication 6, p. 1263-1280.

Taylor,-D.W., 1948. Fundamentals of Soil Mechanics. New York: John Wiley and Sons. Todd, D.K., 1959. Groundwater Hydrology. New York: Wiley. 
WSRC, 1993. Microscopic Examination of Sediment Cores. Savannah River Technology Center - Environmental Sciences Section Operating Procedures, WSRC-L14.1, Rev. 2, p. 1-11.

Zhang, Z., 1994. Use of Uncertainty Methodology in Identification and Classification of Soils Based Upon CPT. Ph.D. Dissertation, Louisiana State University and Agricultural and Mechanical College. 


\section{APPENDIX A RESULTS OF LITERATURE SEARCH}




\section{THIS PAGE INTENTIONALLY LEFT BLANK}




\section{APPENDIX A.1 RESULTS OF INTERNET SEARCH}




\section{THIS PAGE INTENTIONALLY LEFT BLANK}


<title>Lycos search: cone penetrometer technology

$47,834,280$ unique URLs

Found 346,909 documents with the words

$<a$ href="/cgi-bin/pursuit?query=cone.\&terse=standard" $>$ cone $</ a>(8,234)$,

$<a$ href $=$ "/cgi-bin/pursuit?query-penetrometer.\&terse $=$ standard" $>$ penetrometer $</ a>(239)$,

$<a$ href="/cgi-bin/pursuit?query=technology.\&terse=standard">technology $</ a>(19,229)$

"http:/firidium.nttc.edu/CMST/CMST_TOC.html">CMST Technology Summary - Table of Contents

CMST $\langle b>$ Technology $<| b>$ Summary - Table of Contents CHARACTERIZATION, MONITORING, AND SENSOR $<b>$ TECHNOLOGY $<b>$ INTEGRATED PROGRAM (CMST-IP)

४b>TECHNOLOGY<b> SUMMARY DOE/EM-0156T April 1994 TABLE OF CONTENTS...

"http://www.estd.battelle.org/er/demos.html" $>$ Integrated Technology Demonstrations Integrated $\langle b>$ Technolog $\langle b\rangle>$ Demonstrations Integrated $\langle b>$ Technology $\langle b>$ Demonstrations Tinker and Eielson Innovative $\langle b>$ Technolog $y\langle b\rangle$ Demonstrations. Battelle is demonstrating the overall effectiveness...

"http://sc94.ameslab.gov/OTD/tech_summs/Catalog/Tech_Cat_Char_Monitor_index.html">Technol ogy Catalog Index

$40>$ Technology $<b>$ Catalog Index INDEX Site Characterization and Monitoring $\langle b>$ Technology $\langle b\rangle$ Profiles Advanced In Situ Moisture Logging System Broadband Electromagnetics for Three Dimensional

"http://iridium.nttc.edu/VOC_Arid/VOCA_chap1.1.html">VOCs in Arid Soils Technology Summary: Cone Penetrometer

VOCs in Arid Soils $\langle b\rangle$ Technology $\langle a\rangle$ Summary: $\langle b>$ Cone $\langle b\rangle\langle b>$ Penetrometer $\langle b>1.0$ DRIIIING 1.1 HEAVY-WEIGHT $\langle b>C O N E<b>\langle b>$ PENETROMETER $<b>$ TASK DESCRIPTION The objective of the heavy-weight cone

"http://iridium.nttc.edu/CMST/CMST_ch2.3.html"sCMST Tech Summary - Time Domain Reflectometry and Fiber Op.

CMST Tech Summary - Time Domain Reflectometry and Fiber Optic Probes for $4 b>C$ Cone $</ b>$ $<b>$ Penetrometer $<b>2.3$ TIME DOMAIN REFLECTOMETRY AND FIBER OPTIC PROBES FOR THE CONE PENETROMETER TASK...

"http://cmst.ameslab.gov/Cmst-Cp_Reports/MRMR/CH23C222.html">CMST-CP February 1996 Progress Reports - Cone Penetrometer.oo

CMST-CP February 1996 Progress Reports - $\langle b>$ Cone $\langle b\rangle\langle\langle b>$ Penetrometer $\langle b\rangle$ Support Operation, Maintenance, and R\&amp;D Activity Conducted on $\langle b\rangle$ Cone $\langle b\rangle\langle b\rangle$ Penetrometer $\langle b\rangle$ Vehicle CH23C222 - February...

"http://cmst.ameslab.gov/CMST-CP_reports/Aug95/CH231006.html">CMST-CP Aug 1995 Progress Reports - Cone Penetrometer Supp...

CMST-CP Aug 1995 Progress Reports - $\langle b>$ Cone $</ b><b>$ Penetrometer $</ b>$ Support: Operation, Maintenance, and R\&amp;D Activity Conducted on $\langle b>C$ Cone $\langle b\rangle\langle b>$ Penetrometer $\langle b\rangle$ Vehicle CH231006 - August $1995<b>$ Cone 
"http://cmst.ameslab.gov/Rainbow_95/1.8.html">1.8 Miniature Pumps in the Cone Penetrometer Tip for Groun...

1.8 Miniature Pumps in the $\langle b>C$ Cone $\langle\mid b\rangle\langle b>$ Penetrometer $\langle b\rangle$ Tip for Ground Water and Soil Gas Sampling TASK DESCRIPTION Fast, cost-effective analysis of groundwater is needed to characterize waste sites... $\langle b\rangle\langle b r\rangle$

<em> http://cmst.ameslab.gov/Rainbow_95/1.8.html (6k)</em><br>

$<$ font color $=" \# C C 6600^{n}>[63 \%, 2$ of 3 terms relevant $]<$ font $>$

"http:/Www.nttc.edu/Catalog/Tech_Cat_chap4_4.html">Technology Catalog Site Characterization and Monitoring Pr...

$\langle b\rangle$ Technology $\langle\boldsymbol{b}\rangle$ Catalog Site Characterization and Monitoring Profiles $\langle b>C$ Cone $<\mid b\rangle$

$\langle b\rangle$ Penetrometer $\langle b\rangle$ Westinghouse Hanford Company Description The $\langle b>c o n e\langle/ b\rangle$

$<b>$ penetrometer $\langle b>$ is a truck-mounted ...

http://cmst.ameslab.gov/Rainbow_94/CMST_ch2.5.html">CMST Tech Summary - Screening and Quantitative Field Metho...

CMST Tech Summary - Screening and Quantitative Field Methods Coupled to the $\langle b\rangle$ Cone $\langle b\rangle$

$<b>$ Penetrometer $<b>2.5$ Development Of Screening And Quantitative Field Methods Coupled To The

Cone Penetrometer

"http://ramah.geoid.sandia.gov/BEST/techs/aa/tech0220.html"> EM's BEST

EM's BEST Name: Mobile $\langle b>$ Cone $<\mid b\rangle\langle b>$ Penetrometer $\langle b>$ in SC, US Army Owner. Army Corps of

Engineers in SC Status: Availa $\langle b>$ Technology $\langle b>$ Image: Yes Mobile $<b>$ Cone $<b>$

$<b>$ Penetrometer $<b>$ ER Characterization...

"http://geosystems.gatech.edu/Research/geocone.html">Development of an Integrated Optics

Geoenvironmental Cone ...

Development of an Integrated Optics Geoenvironmental $\langle b\rangle$ Cone $\langle b\rangle\langle b\rangle$ Penetrometer $\langle\mid b\rangle$ for

Detecting Subsurface Contaminants

"http://africa.cis.c0.za:81/indsec/transpor/software/dcp.html">DCP: Dynamic Cone Penetrometer DCP: Dynamic $\langle b>$ Cone $\langle b>\langle b>$ Penetrometer $\langle b>$ DCP: Dynamic $\langle b>C$ one $\langle b>\langle b>$ Penetrometer $\langle b\rangle$ Facilities: [News | Events | Messaging | Conferences | Discussion Board | Document Ordering | Search | Help] Path...

"http://sbir.gsfe.nasa.gov/95abstracts/13.06/951893.html">13.06-1282 : MASS SPECTROMETRY WITH CONE PENETROMETER FOR ...

13.06-1282 : MASS SPECTROMETRY WTH $<b>C O N E<b><b>$ PENETROMETER $<b>$ FOR REAL TIME INSITU VOCS AND LITHOLOGY SBIR 95-1 SOLICITATION PROJECT SUMMARY PToposal Number: 13.06-1282 Project Title: MASS SPECTROMETRY...

"http:/cmst.ameslab.gov/Rainbow_95/1.7.html">1.7 In Situ Measurement of Volatile and SemiVolatile Orga...

1.7 In Situ Measurement of Volatile and Semi-Volatile Organic Compounds in the Subsurface:

Development of Screening and Quantitative Field Methods Coupled to the Cone Penetrometer - TASK

DESCRIPTION...

"http://www.nttc.edu/../Profiles/VOCA/Cone_Penetrometer.html">Cone Penetrometer

Cone Penetrometer

<em> http://www.nttc.edu/./Profiles/VOCA/Cone_Penetrometer.html (0k 
"http://ramah.geoid.sandia.gov/BEST/techs/aa/tech0098.htmI" >C Cone Penetrometer Testing for Site Chara

Cone Penetrometer Testing for Site Chara;

"http://ramah.geoid.sandia.gov/BEST/FA/tanks/solutions/cp.html" >COne Penetrometer Deployment Platform

Cone Penetrometer Deployment Platform;

"http://www.nttc.edu/VOC_Arid/VOCA_chap1.1.html" $>$ Heavy-Weight Cone Penetrometer Heavy-Weight Cone Penetrometer

"http://www.etd.ameslab.gov/etd/technologies/projects/esc/technologies/cptlif.html">Cone

Penetrometer Truck with Laser Induced Fluorescence

Cone Penetrometer Truck with Laser Induced Fluorescence; CPT truck;

"http://cmst.ameslab.gov/Tech_Cat.text/10.2.html" $>$ Heavy Weight Cone Penetrometer Heavy Weight $\langle b\rangle$ Cone $\langle b\rangle\langle b\rangle$ Penetrometer $\langle/ b\rangle ;\langle b\rangle\langle b r\rangle$

"http://cmst.ameslab.gov/Tech_Cat.text/4.4.html">Hydrologic Sensors for the Cone Penetrometer System

Hydrologic Sensors for the Cone Penetrometer System;

"http:/www.orge.uf.edu/cgi-bin/cookie-request-fyi-item/v23n04/fyi068.html">RFP: Dynamic Cone Penetrometer

RFP: Dynamic Cone Penetrometer (DCP);

"http://iridium.nttc.edu/CMST/CMST_ch2.5.html">Development of Screening and Quantitative Field Methods Co...

Development of Screening and Quantitative Field Methods Coupled to the Cone Penetrometer

"http://cmst.ameslab.gov/Tech_Cat.tert/6.8.html">Miniature GC for In Situ Monitoring of VOCs within a Cone ...

Miniature GC for In Situ Monitoring of VOCs within a Cone Penetrometer

"http://www.nttc.edu/CMST/CMST_ch2.2.html">CMST Tech Summary: Site Characterization and Penetrometer...

CMST Tech Summary: Site Characterization and $4 b>$ Penetrometer $<b>$ System 2.2 SITE CHARACTERIZATION AND $\measuredangle>$ PENETROMETER $<b>$ SYSTEM TASK DESCRIPTION DOE is seeking new technologies to assist in their efforts...

"http:/www-civils.eng.ox.ac.uk/theses/nutt.html" $>$ D.Phil. Thesis : N.R.F. Nutt

D.Phil. Thesis : N.R.F. Nutt N.R.F. Nutt Doctor of Philosophy,St. Catherine's College, University of Oxford, Hilary Term, 1993 DEVELOPMENT OF THE $<b>C O N E<b>$ PRESSUREMETER Summary The cone pressuremeter...

"http://www-civils.eng.ox.ac.uk/theses/may.html" $>$ D.Phil. Thesis : R.E. May D.Phil. Thesis : R.E. May R.E. May Doctor of Philosophy,Exeter College, Oxford University, Hilary Term, 1987 A Study of the Piezocone $<b>$ Penetrometer $<b>$ Summary The research was intended to enhance the... 
"http://cmst.ameslab.gov/CMST-CP_reports/Sep95/CH241001.html">CMST-CP September 1995 Progress Reports - In-Situ Measurem...

CMST-CP September 1995 Progress Reports - In-Situ Measurement of VOCs and SVOCs in the Subsurface CH241001 - September 1995 Development of Screening and Quantitative Field Methods for theCone $\triangleleft>$ Penetrometer

"http://www.dvbiznet.com/rewei/">R. E. Wright Environmental, Inc.

R. E. Wright Environmental, Inc. R. E. Wright Environmental, Inc. (REWED) provides practical,costeffective solutions to today's environmental challenges. Company Profile Featured Service: Truck Mounted...

"http://www,dtic.dla.mil/envirodod/derpreport/yuma.html">MCAS Yuma, Arizona and Army Corps of Engineers, Minnesota

MCAS Yuma, Arizona and Army Corps of Engineers, Minnesota MCAS Yuma, Arizona and Army Corps of Engineers, Minnesota Faced with tight budgets and the need for expeditious results, both the Marine Corps...

"http://cmst.ameslab.gov/Rainbow_95/1.2.html">1.2Expedited Site Characterization - Application To Federa...

1.2Expedited Site Characterization - Application To Federal Facilities TASK DESCRIPTION A technically innovative approach to environmental site characterization has been developed that integrates all ...

"http://cmst.ameslab.gov/Rainbow_95/7.0.html">7.0Acronym Listing 7.0Acronym Listing ANL Argonne National Laboratory AOTF Acousto-Optic Tunable Filter API Associated Particle Imaging ARA Applied Research Associates, Inc. CAE Clean Air Engineering CBD Commerce Business...

"http://sc94.ameslab.gov/OTD/tech_summs/VOCNAVVOCNA_chap1.1.html">VOCs in Non-Arid Soils Technology Summary: Chemical Fiber...

VOCs in Non-Arid Soils $\langle b>$ Technology $</ b>$ Summary: Chemical Fiber Optic Sensor 1.1 CHEMICAL FIBER OPTIC SENSOR TASK DESCRIPTION The chemical fiber optic sensor is used to monitor in situ contaminant levels...

"http://sc94.2meslab.gov/OTD/tech_summs/Catalog/Tech_Cat_chap4_13.html">Technology Catalog Site Characterization and Monitoring Pr...

Portable Acoustic Wave Sensor Sandia National Laboratories Description The Portable Acoustic Wave Sensor (PAWS) is a downhole sensor being developed to characterize contamination and monitor contaminant..

"http://sc94.2meslab.gov/OTD/tech_summs/CMST/CMST_ch1.1.html">CMST Tech Summary Contaminants in Soils and Groundwater....

CMST Tech Summary - Contaminants in Soils and Groundwater: Expedited Site Characterization at DOE Facilities SECTION 1.0 CONTAMINANTS IN SOILS AND GROUNDWATER 1.1 EXPEDITED SITE CHARACTERIZATION AT DOE... 


\section{APPENDIX A.2 \\ RESULTS OF USC AIKEN ONLINE SEARCH}




\section{THIS PAGE INTENTIONALLY LEFT BLANK}


DIALOG(R)File 89:GeoRef

(C) 1996 American Geological Institute. All its. reserv.

02212536 GEOREF NO.: 96-26084

TITLE: Comparison of borehole geophysics, CPT, resistivity, GPR, and high-resolution seismic data across a shallow structure in unconsolidated sediments

AUTHOR(S): Temples, Tom J.; Wyatt, Douglas E.; Cumbest, Randy; Waddell, Michael G.

CORPORATE SOURCE: U. S. Department of Energy, Alken, SC, United States

MONOGRAPH TITLE: Society of Exploration Geophysicists, 65th annual

intemational meeting; technical program, expanded abstracts with

authors' biographies

AUTHOR(S): Anonymous; Westinghouse Savannah River Co., United States, University of South Carolina, United States

CONFERENCE TITLE: Society of Exploration Geophysicists, 65th annual

international meeting

CONFERENCE LOCATION: Houston, TX, United States

CONFERENCE DATE: Oct. 8-13, 1995

PUBLISHER: Soclety of Exploration Geophysicists, Tulsa, OK, United States

SOURCE: SEG Annual Meeting Expanded. Technical Program Abstracts with

Biographies vol. 65 p. 381-384

DATE: 1995

COUNTRY OF PUBLICATION: United States

ISSN: 1052-3812 REFS.: 16

SUBFILE: $B$

DOCUMENT TYPE: Abstract; Serial; Conference BIBLIOGRAPHIC LEVEL: Analytic

ILLUSTRATIONS: illus.; sects.; sketch map

LANGUAGE: English

ABSTRACT: The geological characterization of the shallow subsiurface in

the unconsolidated sediments of the Atlantic Coastal Plain, and other

unconsolidated sediment regimes, may Involve faulting and channeling not

readily detectable by conventional drilling and mapping. A knowiedge of

these features is required in environmental and geotechnical studies in

areas that may have critical impact to groundwater flow and contaminant

transport. In many cases, shallow structural influences are missed during

site characterization. A case study is presented using ground

penetrating radar (GPR) and high resolution seismiç data, compared with a

geological interpretation from borehole logs and core data, with Weniner

and dipole-dipole resistivity data and with cone penetrometer (CPT)

data in an area where shallow structure is probable and contamination

exists. This study suggests that a correlation may be made for structures

imaged by ground penetrating radar and high resolution seismic data. The

additional information provided by Wenner and dipole-dipole resistivity

surveys, when viewed separately from the other data sources, does not

allow for an adequate picture of the shallow faulting. The data from the cone penetrometer (CPT) investigation, when compared to existing well data, did not define the nature of the shallow structures. A comparison of all of the techniques allows for the small scale shallow structures, imaged by the continuous techniques (GPR, seismic) to be compared with the non-continuous techniques (borings, CPT) used to define lithology. Since the various techniques have differing depths of investigation, an effective depth of influence of the shallow structures may be estimated.

COORDINATES: Latitude: N331000 ; N335200 ; Longitude: W0811200 ; W0820300 
Latitude: N330700 ; N333000 ; Longitude: W0811300 ; W0814700

DESCRIPTORS: Alken County South Carolina; Atlantic Coastal Plain; Barnwell

County South Carolina; boreholes; case studies; cone penetration

tests; electrical methods; geophysical methods; ground-penetrating radar;

high-resolution methods; penetration tests; radar methods; resistivity;

Savannah River Plant; seismic logging; seismic methods; shallow depth;

soll mechanics; South Carolina; south-central South Carolina;

unconsolidated materials; United States; well-logging

SECTION HEADINGS: 20 (Geophysics, Applied); 30 (Engineering Geology)

$18 / 9 / 2$

DIALOG(R)File 89:GeoRef

(c) 1996 American Geological Institute. All rts. reserv.

02209662 GEOREF NO.: $96-23138$

TITLE: Integration of innovative and traditional investigative

technologies in subsurface hydrogeological characterization at the

Savannah River Site, Aiken, South Carolina

AUTHOR(S): Van Pelt, Robert S.; McAdams, Thomas D.

CORPORATE SOURCE: Westinghouse Savannah River Company, Aiken, SC, United

States

MONOGRAPH TITLE: Geological Society of America, 1995 annual meeting

AUTHOR(S): Anonymous

CONFERENCE TITLE: Geological Society of America, 1995 annual meeting

CONFERENCE LOCATION: New Orleans, LA, United States

CONFERENCE DATE: Nov. 6-9, 1995

PUBLISHER: Geological Society of America (GSA), Boulder, CO, United States

SOURCE: Abstracts with Programs - Geological Society of America vol. 27

no. 6 p. 100

DATE: 1995

COUNTRY OF PUBLICATION: United States

CODEN: GAAPBC ISSN: 0016-7592

SUBFILE: $B$

DOCUMENT TYPE: Abstract; Serial; Conference BIBLIOGRAPHIC LEVEL: Analytic

LANGUAGE: English

COORDINATES: Latitude: N331000 ; N335200 ; Longitude: W0811200 ; W0820300

DESCRIPTORS: Alken County South Carolina; Aiken South Carolina; cone

penetration tests; cost; data acquisition; drilling; ground water,

penetration tests; plate tectonics; plumes; pollution; reconstruction;

remediation; Savannah River Plant; South Carolina; technology; United

States

SECTION HEADINGS: 22 (Engineering \& Environmental Geology)

$18 / 9 / 4$

DIALOG(R)File 89:GeoRef

(c) 1996 American Geological Institute. All rts. reserv.

02206829 GEOREF NO.: 96-20197

TITLE: Cone penetrometer technology; clarity, speed and value in

site characterization

AUTHOR(S): Nelligan, Frederick M.; Harlick, Alison J.

CORPORATE SOURCE: SAIC, Bothell, WA, United States 
MONOGRAPH TITLE: Geological Society of America, 1895 annual meeting

AUTHOR(S): Anonymous: Automated Sciences Group, United States

CONFERENCE TITLE: Geological Society of America, 1995 annual meeting

CONFERENCE LOCATION: New Orleans, LA, United States

CONFERENCE DATE: Nov. 6-9, 1995

PUBLISHER: Geological Society of America (GSA), Boulder, CO, United States

SOURCE: Abstracts with Programs - Geological Society of America vol. 27

no. 6 p. 403

DATE: 1995

COUNTRY OF PUBLICATION: United States

CODEN: GAAPBC ISSN: 0016-7592

SUBFILE: $B$

DOCUMENT TYPE: Abstract; Serial; Conference BIBLIOGRAPHIC LEVEL: Analytic

LANGUAGE: English

DESCRIPTORS: accuracy; aquitards; chlorinated hydrocarbons; clastic

sediments; cone penetration tests; cost; dense nonaqueous phase

liquids; faults; ground water; penetration tests; pollutants; pollution;

sand; sediments; site exploration; soils; technology; transport;

trichloroethylene

SECTION HEADINGS: 22 (Engineering \& Environmental Geology)

18/9/5

DIALOG(R)File 89:GeoRef

(C) 1996 American Geological Institute. All rts. reserv.

02206826 GEOREF NO.: 96-20194

TITLE: Preliminary geophysical characterization of groundwater

remediation field laboratory, Dover Air Force Base, Delaware

AUTHOR(S): Kadinsky-Cade, Katharine; Cardimona, Steve

CORPORATE SOURCE: Phillips Laboratory, Earth Sciences Division, Hanscom

Air Force Base, MA, United States

MONOGRAPH TITLE: Geological Society of America, 1995 annual meeting

AUTHOR(S): Anonymous

CONFERENCE TITLE: Geological Society of America, 1995 annual meeting

CONFERENCE LOCATION: New Orleans, LA, United States

CONFERENCE DATE: Nov. 6-9, 1995

PUBLISHER: Geological Society of America (GSA), Boulder; CO, United States

SOURCE: Abstracts with Programs - Geological Society of America vol. 27

no. 6 p. 402

DATE: 1995

COUNTRY OF PUBLICATION: United States

CODEN: GAAPBC ISSN: 0016-7592

SUBFILE: $B$

DOCUMENT TYPE: Abstract; Serial; Conference BIBLIOGRAPHIC LEVEL: Analytic LANGUAGE: English

COORDINATES: Latitude: N385000 ; N391700 ; Longitude: W0752000 ; W0754500

DESCRIPTORS: aquifers; aquitards; cone penetration tests; corrections;

data processing; Delaware; Dover Delaware; geophones; geophysical surveys

; ground water, ground-penetrating radar, Kent County Delaware;

penetration tests; radar methods; remediation; resistivity; seismic

sources; seismic surveys; surveys; United States; variations

SECTION HEADINGS: 20 (Geophysics, Applied) 
$18 / 9 / 6$

DIALOG(R)File 89:GeoRef

(C) 1996 American Geological Institute. All rts. reserv.

02206824 GEOREF NO.: $96-20192$

TITLE: Characterization of the U. S. Air Force groundwater remediation

field laboratory; a facility for the contained release of DNAPLS

AUTHOR(S): Noll, Mark R.; Smith, Mark H.

CORPORATE SOURCE: Applied Research Assoclates, Dover Air Force Base, DE, United States

MONOGRAPH TITLE: Geological Society of America, 1995 annual meeting

AUTHOR(S): Anonymous; Environics Directorate, Armstrong Laboratory,

United States

CONFERENCE TITLE: Geological Society of America, 1995 annual meeting

CONFERENCE LOCATION: New Orleans, LA, United States

CONFERENCE DATE: Nov. 6-9, 1995

PUBLISHER: Geological Society of America (GSA), Boulder, CO, United States

SOURCE: Abstracts with Programs - Geological Society of America vol. 27

no. 6 p. 402

DATE: 1995

COUNTRY OF PUBLICATION: United States

CODEN: GAAPBC ISSN: 0016-7592

SUBFILE: $B$

DOCUMENT TYPE: Abstract; Serial; Conference BIBLIOGRAPHIC LEVEL: Analytic

LANGUAGE: English

COORDINATES: Latitude: N385000 ; N3917.00 ; Longitude: W0752000 ; W0754500

DESCRIPTORS: aquifers; boreholes; chemical properties; cone penetration

tests; Delaware; dense nonaqueous phase liquids; Dover Delaware; field

studies; ground water, hydraulic conductivity ; Kent County Delaware;

mineral composition; monitoring; penetration tests; pollutants; pollution

; remediation; soils; technology; testing; three-dimensional models;

United States; water table

SECTION HEADINGS: 22 (Engineering \& Environmental Geology)

$18 / 9 / 10$

DIALOG(R)File 89:GeoRef

(C) 1996 American Geological Institute. All rts. reserv.

02180673 GEOREF NO.: $95-62758$

TITLE: Site characterization and application of horizontal wells for ground water remediation at the Dow Chemical Company, Louisiana Division in Plaquemine, Louisiana

AUTHOR(S): Dupree, Ivy B.; Meyer, Eric W.

CORPORATE SOURCE: Dow Chemical Company, Plaquemine, LA, United States

MONOGRAPH TITLE: AAPG Gulf Coast Section meeting; abstracts

AUTHOR(S): Anonymous; Dow Environmental, United States

CONFERENCE TITLE: AAPG Gulf Coast Section meeting

CONFERENCE LOCATION: Baton Rouge, LA, United States

CONFERENCE DATE: OCt. 25-27, 1995

PUBLISHER: American Association of Petroleum Geologists, Tulsa, OK, United

States

SOURCE: AAPG Bulletin vol. 79 no. 10 p. 1557 
DATE: 1995

COUNTRY OF PUBLICATION: United States

CODEN: AABUD2 ISSN: 0149-1423

SUBFILE: B

DOCUMENT TYPE: Abstract; Serial; Conference BIBLIOGRAPHIC LEVEL: Analytic

LANGUAGE: English

DESCRIPTORS: bloremediation; cone penetration tests; detection; Dow

Chemical Company; drilling; ground water, Gulf Coastal Plain; horizontal

drilting; hydraulic conductivity ; Louisiana; organic materials;

penetration tests; Plaquemine Louisiana; pollutants; pollution;

remediation; site exploration; soils; three-dimensional models; United

States; waste disposal; well logs

SECTION HEADINGS: 22 (Engineering \& Environmental Geology)

$18 / 9 / 12$

DIALOG(R)File 89:GeoRef

(C) 1996 American Geological Institute. All rts, reserv.
"Note: Requested Inter-Library Loan for this document. $\quad 6 / 19 / 96$

02154247 GEOREF NO.: 95-34492

MONOGRAPH TITLE: Use of uncertainty methodology in identification and

classification of soils based upon CPT

AUTHOR(S): Zhang, Zhongjie

DATE: $1994216 \mathrm{p}$.

UNIVERSITY: Louisiana State University and Agricultural and Mechanical

College, Baton Rouge, LA, United States

ZEGREE LEVEL: Doctoral

COUNTRY OF PUBLICATION: United States

SUBFILE: $B$

DOCUMENT TYPE: Thesis BIBLIOGRAPHIC LEVEL: Monographic

LANGUAGE: English

AVAILABILITY: Univ. Microfilms, Ann Arbor, MI, United States

DESCRIPTORS: classification; cone penetration tests; correlation

coefficient; identification ; methods; penetration tests; soil mechanics

: statistical analysis

SECTION HEADINGS: 30 (Engineering Geology)

18/9/13

DIALOG(R)File 89:GeoRef

(C) 1996 American Geological Institute. All rts. reserv.

02138512 GEOREF NO.: 95-16379

TITLE: The use of contaminant screening tools, remote sampling techniques

and radiological containment's in the RFURI characterization of the $L$

area oll and chemical basin; a case study, Savannah River Site, Alken,

South Carolina

AUTHOR(S): Blount, Gerald C.

CORPORATE SOURCE: Westinghouse Savannah River Company, Environmental

Restoration Department, Alken, SC, United States

MONOGRAPH TITLE: Geological Society of America, 1994 annual meeting

AUTHOR(S): Anonymous

CONFERENCE TITLE: Geological Society of America, 1994 annual meeting

CONFERENCE LOCATION: Seattle, WA, United States 
CONFERENCE DATE: Oct. 24-27, 1994

PUBLISHER: Geological Society of America (GSA), Boulder, CO, United States

SOURCE: Abstracts with Programs - Geological Society of America vol. 26

no. 7 p. 409

DATE: 1994

COUNTRY OF PUBLICATION: United States

CODEN: GAAPBC ISSN: 0016-7592

SUBFILE: $B$

DOCUMENT TYPE: Abstract; Serial; Conference BIBLIOGRAPHIC LEVEL: Analytic

LANGUAGE: English

DESCRIPTORS: actinides; Aiken County South Carolina; Aiken South Carolina;

alkaline earth metals; Am-241; americium; case studies; chlorinated

hydrocarbons; Co-60; cobalt; cone penetration tests; Eu-155/Eu-152;

europium; ground-penetrating radar; halogens; I-129; lodine; isotope

ratios; isotopes; metals; monitoring; penetration tests; plutonium;

pollutants; pollution; Pu-239; radar methods; radioactive isotopes; rare

earths; remote sensing; sampling; Savannah River Plant; sediments;

seepage; soil gases; solvents; South Carolina; Sr-90; strontium;

techniques; tetrachloroethylene; trichloroethylene; U-235; United States;

unsaturated zone; uranium; water wells; wells

SECTION HEADINGS: 22 (Engineering \& Environmental Geology)

18/9/14

DIALOG(R)File 89:GeoRef

(C) 1996 American Geological Institute. All rts. reserv.

02137537 GEOREF NO.: 95-15147

TITLE: Liquefaction and flow failure during earthquakes

AUTHOR(S): Ishihara, $K$.

CORPORATE SOURCE: University of Tokyo, Tokyo, Japan

PUBLISHER: Institution of Civil Engineers, London, United Kingdom

SOURCE: Geotechnique vol. 43 no. 3 p. 351-415

DATE: 1993

COUNTRY OF PUBLICATION: United Kingdom

CODEN: GTNQA8 ISSN: 0016-8505 REFS.: 88

SUBFILE: $B$

DOCUMENT TYPE: Serial BIBLIOGRAPHIC LEVEL: Analytic

ILUSTRATIONS: Illus.; 4 tables; sketch maps

LANGUAGE: English

NOTE: Br. Geotech. Soc. 33rd Rankine lecture

DESCRIPTORS: amplitude; Asia; case studies; Chiba Japan; clastic sediments;

cone penetration tests; earthquakes; elastic waves; Far East;

foundations; geologic hazards; Honshu; Japan; land subsidence;

liquefaction; loading; Loma Prieta earthquake 1989; Luzon earthquake 1990

; penetration tests; pore pressure ; pressure; sample preparation; San

Femando earthquake 1971; sand; sediments; settlement; shear stress;

stress; Tia Juana Sand; Toyoura Sand; triaxial tests

SECTION HEADINGS: 30 (Engineering Geology)

$18 / 9 / 15$

DIALOG(R)File 89:GeoRef

(C) 1996 American Geological Institute. All rts. reserv. 
02113612 GEOREF NO.: $94-45432$

TITLE: Improved soil characterization for pipe piles in sand in API

RP-2A

AUTHOR(S): Hossain, M. K.; Briaud, J. L.

CORPORATE SOURCE: Texas A\&M University, College Station, TX, United

States

MONOGRAPH TITLE: Proceedings of the 25th annual Offshore technology

conference

AUTHOR(S): Ahrendsen, Bruce K. (chairperson)

CORPORATE SOURCE: Fugro-McClelland Marine Geosciences, Houston, TX,

United States

CONFERENCE TITLE: 25th annual Offshore technology conference

CONFERENCE LOCATION: Houston, TX, United States

CONFERENCE DATE: May 3-6, 1993

PUBLISHER: Offshore Technology Conference, (Dallas, TX), United States

SOURCE: Proceedings - Offshore Technology Conference vol. 25 Vol. 2 p.

II:637-11:654

DATE: 1993

COUNTRY OF PUBLICATION: United States

CODEN: OSTCBA ISSN: 0160-3663 REFS.: 32

SUBFILE: $B$

DOCUMENT TYPE: Serial; Conference BIBLIOGRAPHIC LEVEL: Analytic

ILLUSTRATIONS: illus.; 6 tables

LANGUAGE: English

DESCRIPTORS: American Petroleum Institute; analysis; clastic sediments;

cone penetration tests; earth pressure; foundations; load tests;

offshore; penetration tests; piles; sand; sediments; soll mechanics;

stress

SECTION HEADINGS: 30 (Engineering Geology)

18/9/16

DIALOG(R)File 89:GeoRef

(C) 1996 American Geological Institute. All its. reserv.
"Note: Requested Inter-Library Loan

for this document. $\quad 6 / 19 / 96$

02109963 GEOREF NO.: 94-41512

TITLE: Soil compaction and consolidation

AUTHOR(S): Abramson, Lee W.

MONOGRAPH TITLE: Ground control and improvement

AUTHOR(S): Xanthakos, Petros P.; Abramson, Lee W.; Bruce, Donald A.

PUBLISHER: John Wiley and Sons, New York, NY, United States p. 234-330

DATE: 1994

COUNTRY OF PUBLICATION: United States

ISBN: 0-471-55231-3

REFS.: 72

SUBFILE: $B$

DOCUMENT TYPE: Book BIBLIOGRAPHIC LEVEL: Analytic

ILLUSTRATIONS: Illus.; 4 tables

LANGUAGE: English

DESCRIPTORS: applications; bearing capacity; case studies; cohesionless

materials; compaction; cone penetration tests; consolidation;

embankments; grouting; liquefaction potential; penetration tests;

permeability ; porosity; settlement; shear strength; slope stability; 
soll mechanics

SECTION HEADINGS: 30 (Engineering Geology)

18/9/17

DIALOG(R)File 89:GeoRef

(c) 1996 American Geological Institute. All rts. reserv.

02106922 GEOREF NO.: 94-38425

TITLE: Utilization of marginal lands for construction in the Niger Delta

AUTHOR(S): Abam, T.K. S.; Okogbue, C. O.

CORPORATE SOURCE: Rivers State Polytechnic, School of Engineering, Bori,

Nigeria; University of Nigeria, Nigeria

PUBLISHER: Intemational Association of Engineering Geology, Krefeld,

Intemational

SOURCE: Bulletin of the Intemational Association of Engineering Geology

vol. 48 p. 5-14

DATE: 1993

COUNTRY OF PUBLICATION: Intemational

CODEN: BIEGB6 ISSN: 0074-1612 REFS.: 7

SUBFILE: $B$

DOCUMENT TYPE: Serial BIBLIOGRAPHIC LEVEL: Analytic

ILLUSTRATIONS: illus.; 3 tables; sketch maps

LANGUAGE: English SUMMARY LANGUAGE: French

DESCRIPTORS: Africa; case studies; clastic sediments; compressibility;

cone penetration tests; construction; engineering geology; Niger Delta

; Nigeria; Okrika Nigeria; penetration tests; permeability ; Port

Harcourt Nigeria; reclamation; sand; sediments; settlement; soil

mechanics; stress; utilization; West Africa

SECTION HEADINGS: 30 (Engineering Geology)

18/9/18

DIALOG(R)File 89:GeoRef

(c) 1996 American Geological Institute. All rts. reserv.

02102367 GEOREF NO.: 94-33846

MONOGRAPH TITLE: Hydrogeology, ground-water quality, and potential for water-supply contamination near an abandoned wood-preserving plant site at Jackson, Tennessee

AUTHOR(S): Parks, William S.; Mirecki, June E.; Kingsbury, James A.

CORPORATE SOURCE: U. S. Geological Survey, Memphis, TN, United States

PUBLISHER: U. S. Geological Survey, (Reston, VA), United States

SOURCE: Water-Resources Investigations

DATE: $199376 \mathrm{p}$.

REPORT NO.: WRI $93-4170$

COUNTRY OF PUBLICATION: United States

CODEN: WRIND3 ISSN: 0092-332X REFS.: 32

SUBFILE: $B$; USGS

DOCUMENT TYPE: Serial; Report BIBLIOGRAPHIC LEVEL: Monographic

ILLUSTRATIONS: illus.; 16 tables; sketch maps

LANGUAGE: English

AVAILABILITY: U. S. Geol. Surv., Denver, CO, United States

NOTE: Prepared in cooperation with the U. S. Environmental Protection 
Agency

COORDINATES: Latitude: N353500 ; N354000 ; Longitude: W0884700 ; W0885400

DESCRIPTORS: alluvium aquifers; American Creosote Works; aquifers; creosote

; data acquisition; direct push technology ; Fort Pillow Aquifer,

ground water; hydraulic conductivity ; Jackson Tennessee; levels;

Madison County Tennessee; pollutants; polluted water, pollution; sampling

; site exploration; Superfund; techniques; Tennessee; United States; USGS

; water quality; water supply; water wells; wells; west-central Tennessee

SECTION HEADINGS: 21 (Hydrogeology \& Hydrology); 22 (Engineering \&

Environmental Geology)

$18 / 9 / 19$

DIALOG(R)File 89:GeoRef

(C) 1996 American Geological Institute. All its. reserv.

02099665 GEOREF NO.: $94-31143$

TITLE: Calibration chamber studies of piezocone tests in cohesive soils

AUTHOR(S): Kurup, P. U.; Voyiadjis, G. Z; Tumay, M. T.

CORPORATE SOURCE: Louisiana State University, Department of Civil

Engineering, Baton Rouge, LA, United States

PUBLSSHER: American Society of Civil Engineers, New York, NY, United States

SOURCE: Joumal of Geotechnical Engineering vol. 120 no. 1 p. 81-107

DATE: 1994

COUNTRY OF PUBLICATION: United States

CODEN: JGENDZ ISSN: 0733-9410 REFS.: 43

SUBFILE: $B$

DOCUMENT TYPE: Serial BIBLJOGRAPHIC LEVEL: Analytic

ILLUSTRATIONS: illus.; 7 tables

LANGUAGE: English

DESCRIPTORS: bearing capacity; calibration; cohesive materials; cone

penetration tests; laboratory studies; penetration tests; pore

pressure ; pressure; sample preparation; shear strength; soil mechanics;

strain

SECTION HEADINGS: 30 (Engineering Geology)

18/9/20

DIALOG(R)File 89:GeoRef

(C) 1996 American Geological Institute. All rts. reserv.

02081685 GEOREF NO.: $94-13044$

TITLE: Cone penetration in cemented sands; bearing capacity

Interpretation

AUTHOR(S): Puppala, Anand J.; Acar, Yalcin B.; Senneset, Kare

CORPORATE SOURCE: Louisiana Transportation Research Center, Baton Rouge,

LA, United States; Louisiana State University, United States, Norwegian

Institute of Technology, Norway

SOURCE: Joumal of Geotechnical Engineering vol. 119 no. 12 p.

1990-2001

DATE: 1993

COUNTRY OF PUBLICATION: United States

CODEN: JGENDZ ISSN: 0733-9410 REFS.: 20

SUBFILE: $B$ 
DOCUMENT TYPE: Serial BIBLIOGRAPHIC LEVEL: Analytic

ILLUSTRATIONS: illus.; 3 tables

LANGUAGE: English

DESCRIPTORS: bearing capacity; behavior, cementation; clastic sediments;

cone penetration tests; deformation; diagenesis; earth pressure;

models; penetration tests; pore pressure ; pressure; sand; sediments;

soll mechanics

SECTION HEADINGS: 30 (Engineering Geology)

18/9/21

DIALOG(R)File 89:GeoRef

(C) 1996 American Geological Institute. All rts. reserv.

02076856 GEOREF NO.: 94-08215

TITLE: Hydrogeologic site characterization using the cone penetrometer test and hydrocone groundwater sampling at a Superfund Site in northwestern New Mexico

AUTHOR(S): Skelly, Michael F.; Keshian, Berg

CORPORATE SOURCE: Roy F. Weston, Albuquerque, NM, Mexico

MONOGRAPH TITLE: Geological Society of America, 1991 annual meeting

AUTHOR(S): Anonymous

CONFERENCE TITLE: Geological Society of America, 1991 annual meeting

CONFERENCE LOCATION: San Diego, CA, United States

CONFERENCE DATE: Oct. 21-24, 1991

SOURCE: Abstracts with Programs - Geological Society of America vol. 1991

p. 244

DATE: 1991

COUNTRY OF PUBLICATION: United States

CODEN: GAAPBC ISSN: 0016-7592

SUBFILE: $B$

DOCUMENT TYPE: Abstract; Serial; Conference BIBLIOGRAPHIC LEVEL: Analytic

LANGUAGE: English

DESCRIPTORS: aquifers; conductivity; cone penetration tests; ground water, hydrocone sampling; New Mexico; northwestern New Mexico; penetration tests; remediation; sampling; soils; Superfund; United States

SECTION HEADINGS: 22 (Engineering \& Environmental Geology)

18/9/22

DIALOG(R)File 89:GeoRef

(c) 1996 American Geological Institute. All rts. reserv.

02068588 GEOREF NO.: 93-48111 BIBL. INDEX GEOLOGY NO.: 93-47270

TITLE: Seismic cone analysis using digital signal processing for dynamic

site characterization

AUTHOR(S): Campanella, R. G.; Stewart, W.P.

CORPORATE SOURCE: Univ. B. C., Dep. Civ. Eng., Vancouver, BC, Canada

SOURCE: Canadian Geotechnical Joumal = Revue Canadienne de Geotechnique

vol. 29 no. 3 p. $477-480$

DATE: 1992

COUNTRY OF PUBLICATION: Canada

CODEN: CGJOAH ISSN: 0008-3674 REFS.: 15

SUBFILE: $B$ 
DOCUMENT TYPE: Serial BIBLIOGRAPHIC LEVEL: Analytic

"LUSTRATIONS: illus.; 1 table

ANGUAGE: English SUMMARY LANGUAGE: French

DESCRIPTORS: accelerometers; amplitude; body waves; cone penetration tests; elastic constants; elastic waves; Fourier analysis; frequency

domain analysis; geophones; in situ; P-waves; penetration tests; S-waves;

selsmic response; shear modulus; soil mechanics; stress; velocity

SECTION HEADINGS: 30 (Engineering Geology)

\section{$18 / 9 / 23$}

DIALOG(R)File 89:GeoRef

(C) 1996 American Geological Institute. All its. reserv.

02063479 GEOREF NO.: 93-42983 BIBL. INDEX GEOLOGY NO.: 93-47607

TITLE: Measurement of the properties of sand in a calibration chamber AUTHOR(S): Schnaid, F.; Houlsby, G. T.

CORPORATE SOURCE: Oxford Univ., Dep. Eng. Scl., Oxford, United KIngdom

SOURCE: Geotechnique vol. 42 no. 4 p. 587-601

DATE: 1992

COUNTRY OF PUBLICATION: United Kingdom

CODEN: GTNQA8 ISSN: 0016-8505 REFS.: 53

SUBFILE: $B$

DOCUMENT TYPE: Serial BIBLIOGRAPHIC LEVEL: Analytic

ILLUSTRATIONS: illus.; 4 tables

LANGUAGE: English SUMMARY LANGUAGE: French

ESCRIPTORS: clastic sediments; cone penetration tests; in situ;

measurement; penetration tests; permeability : sand; sediments; shear

strength; soil mechanics; stiffness; stress; testing

SECTION HEADINGS: 30 (Engineering Geology)

\section{8/9/24}

DIALOG(R)File 89:GeoRef

(C) 1996 American Geological Institute. All rts. reserv.

02038216 GEOREF NO.: 93-17716 BIBL. INDEX GEOLOGY NO.: 93-20014

TITLE: General report/Discussion session 24; Road and earthwork constructions on soft soils

AUTHOR(S): Rathmayer, H. G.; Tremblay, M.

CORPORATE SOURCE: Tech. Res. Cent. Finland, Espoo, Finland

MONOGRAPH TITLE: Proceedings of the Twelfth international conference on

Soil mechanics and foundation engineering - Comptes rendus du douzieme congres intemational de mecanique des sols et des travaux de fondations

AUTHOR(S): Anonymous; Sived. Natl. Road Adm., Sweden

CONFERENCE TITLE: Twelfth intemational conference on soil mechanics and foundation engineering - Douzieme congres intemational de mecanique des sols et des travaux de fondations

CONFERENCE LOCATION: Rio de Janeiro, Brazil

CONFERENCE DATE: Aug. 13-18, 1989

SOURCE: Proceedings of the International Conference on Soil Mechanics and oundation Engineering = Comptes Rendus du Congres International de Mecanique des Sols et des Travaux de Fondations vol. 12 Vol. 4 p.

2701-2713 
DATE: 1992

COUNTRY OF PUBLICATION: International

CODEN: PCSMB2 REFS.: 43

SUBFILE: $B$

DOCUMENT TYPE: Serial; Conference BIBLIOGRAPHIC LEVEL: Analytic

ILLUSTRATIONS: illuS.

LANGUAGE: English

DESCRIPTORS: clastic sediments; clay; cohesive materials; cone

penetration tests; construction; design; earthworks; embankments; models

; penetration tests; pore pressure ; pressure; pressuremeters;

sampling; sediments; settlement; soil mechanics; stability; stabilization

; stress; vane tests

SECTION HEADINGS: 30 (Engineering Geology)

18/9/25

DIALOG(R)File 89:GeoRef

(c) 1996 American Geological Institute. All rts. reserv.

02038207 GEOREF NO.: 93-17707 BIBL. INDEX GEOLOGY NO.: 93-20008

TITLE: General reportDiscussion session 15; Static and dynamic testing of piles

AUTHOR(S): Prakash, Shamsher, Holeyman, Alain

CORPORATE SOURCE: Univ. Mo. at Rolla, Rolla, MO, United States

MONOGRAPH TITLE: Proceedings of the Twelfth international conference on

Soil mechanics and foundation engineering - Comptes rendus du douzieme congres international de mecanique des sols et des travaux de fondations

AUTHOR(S): Anonymous; Harding Lawson Assoc., United States

CONFERENCE TITLE: Twelfth international conference on soil mechanics and

foundation engineering - Douzieme congres intemational de mecanique des

sols et des travaux de fondations

CONFERENCE LOCATION: Rio de Janeiro, Brazil

CONFERENCE DATE: Aug. 13-18, 1989

SOURCE: Proceedings of the Intemational Conference on Soil Mechanics and

Foundation Engineering = Comptes Rendus du Congres International de

Mecanique des Sols et des Travaux de Fondations vol. 12 Vol. 4 p.

2607-2613

DATE: 1992

COUNTRY OF PUBLICATION: Intemational

CODEN: PCSMB2 REFS.: 4

SUBFILE: $B$

DOCUMENT TYPE: Serial; Conference BIBLIOGRAPHIC LEVEL: Analytic

LANGUAGE: English

DESCRIPTORS: cone penetration tests; dynamics; foundations; load tests;

penetration tests; piles; pore pressure ; pressure; pressuremeters;

settlement; testing

SECTION HEADINGS: 30 (Engineering Geology)

18/9/26

DIALOG(R)File 89:GeoRef

(C) 1996 American Geological Institute. All rts. reserv.

02038200 GEOREF NO.: 93-17700 BIBL. INDEX GEOLOGY NO.: 93-19894 
TITLE: General report/Discussion session 8; Geotechnical properties of zoarse grained solls

UTHOR(S): Charles, J. A.

CORPORATE SOURCE: Build. Res. Establ., Garston, United KIngdom

MONOGRAPH TITLE: Proceedings of the Twelfth international conference on

Soil mechanics and foundation engineering - Comptes rendus du douzleme

congres intemational de mecanique des sols et des travaux de fondations

AUTHOR(S): Anonymous

CONFERENCE TITLE: Twelfth intemational conference on soll mechanics and foundation engineering - Douzieme congres intemational de mecanique des sols et des travaux de fondations

CONFERENCE LOCATION: Rio de Janeiro, Brazil

CONFERENCE DATE: Aug. 13-18, 1989

SOURCE: Proceedings of the International Conference on Soil Mechanics and Foundation Engineering = Comptes Rendus du Congres Intemational de Mecanique des Sols et des Travaux de Fondations vol. $12 \mathrm{Vol} .4 \mathrm{p}$. 2495-2519

DATE: 1992

COUNTRY OF PUBLICATION: Intemational

CODEN: PCSMB2 REFS.: 144

SUBFILE: $B$

DOCUMENT TYPE: Serial; Conference BIBLIOGRAPHIC LEVEL: Analytic

ILLUSTRATIONS: illus.; 3 tables

LANGUAGE: English

DESCRIPTORS: coarse-grained materials; compressibility; cone penetration tests; deformation; earth pressure; erosion; laboratory studies;

nathematical models; penetration tests; permeability ; pore ' pressure ; porosity; pressure; settlement; shear strength; size distribution; soil mechanics; stress

SECTION HEADINGS: 30 (Engineering Geology)

18/9/27

DIALOG(R)File 89:GeoRef

(C) 1996 American Geological Institute. All rts. reserv.

02038190 GEOREF NO.: 93-17690 BIBL. INDEX GEOLOGY NO.: 93-19904

TITLE: General report/Discussion session 2; SPT, CPT, pressuremeter testing and recent developments in in-situ testing; Part 2, The standard penetration test, state-of-the-art report

AUTHOR(S): Decourt, Luciano

CORPORATE SOURCE: Eng. Consult., Sao Paulo, Brazil

MONOGRAPH TITLE: Proceedings of the Twelfth international conference on Soil mechanics and foundation engineering - Comptes rendus du douzieme congres intemational de mecanique des sols et des travaux de fondations AUTHOR(S): Anonymous

CONFERENCE TITLE: Twelfth intemational conference on soil mechanics and foundation engineering - Douzieme congres intemational de mecanique des sols et des travaux de fondations CONFERENCE LOCATION: Rio de Janeiro, Brazil

CONFERENCE DATE: Aug. 13-18, 1989

UURCE: Proceedings of the International Conference on Soll Mechanics and Foundation Engineering = Comptes Rendus du Congres International de

Mecanique des Sols et des Travaux de Fondations vol. $12 \mathrm{Vol} .4 \mathrm{p}$. 
2405-2416

DATE: 1992

COUNTRY OF PUBLICATION: Intemational

CODEN: PCSMB2 REFS.: 141

SUBFILE: $B$

DOCUMENT TYPE: Serial; Conference BIBLIOGRAPHIC LEVEL: Analytic

ILLUSTRATIONS: Illus.; 7 tables

LANGUAGE: English

DESCRIPTORS: bearing capacity; clastic sediments; compressibility; cone penetration tests; in situ; penetration tests; pore pressure ;

pressure; sand; sediments; settlement; soil mechanics; stiffness; stress;

testing; triaxial tests

SECTION HEADINGS: 30 (Engineering Geology)

18/9/28

DIALOG(R)File 89:GeoRef

(c) 1996 American Geological Institute. All rts. reserv.

02038189 GEOREF NO.: 93-17689 BIBL. INDEX GEOLOGY NO.: 93-19971

TITLE: General report/Discussion session 2; SPT, CPT, pressuremeter

testing and recent developments in in-situ testing; Part 1, All tests

except SPT

AUTHOR(S): Lunne, T.; Lacasse, S.; Rad, N. S.

CORPORATE SOURCE: Norw. Geotech. Inst., Norway

MONOGRAPH TITLE: Proceedings of the Twelfth international conference on

Soil mechanics and foundation engineering - Comptes rendus du douzieme

congres intemational de mecanique des sols et des travaux de fondations

AUTHOR(S): Anonymous

CONFERENCE TITLE: Twelfth international conference on soil mechanics and foundation engineering - Douzieme congres intemational de mecanique des sols et des travaux de fondations

CONFERENCE LOCATION: Rio de Janeiro, Brazil

CONFERENCE DATE: Aug. 13-18, 1989

SOURCE: Proceedings of the International Conference on Soil Mechanics and Foundation Engineering = Comptes Rendus du Congres International de Mecanique des Sols et des Travaux de Fondations vol. $12 \mathrm{Vol} .4 \mathrm{p}$. 2339-2403

DATE: 1992

COUNTRY OF PUBLICATION: International

CODEN: PCSMB2 REFS.: 269

SUBFILE: B

DOCUMENT TYPE: Serial; Conference BIBLIOGRAPHIC LEVEL: Analytic ILLUSTRATIONS: illus.; 6 tables

LANGUAGE: English

DESCRIPTORS: autocorrelation; bearing capacity; body waves; clastic

sediments; clay; compressibility; cone penetration tests; creep; deformation; dilatancy; dilatometers; elastic constants; elastic waves; electrical conductivity; hydraulic fracturing; in situ; mass movements; penetration tests; permeability : plasticity; pore pressure ; pressure; pressuremeters; resistivity; S-waves; sediments; shear modulus; shear strength; soil mechanics; statistical analysis; stiff clays; strain ; stress; surface waves; testing; thermal conductivity; vane tests; velocity; Young's modulus 
SECTION HEADINGS: 30 (Engineering Geology)

18/9/29

DIALOG(R)File 89:GeoRef

(C) 1996 American Geological Institute. All rts. reserv.

02037866 GEOREF NO.: 93-17366 BIBL. INDEX GEOLOGY NO.: 93-19983

TITLE: Effect of lateral stress on CPT penetration pore pressures

(discussion and closure)

AUTHOR(S): Mayne, Paul W.; Kulhawy, Fred H.; Sully, J. P.; Campanella, R.

G.

CORPORATE SOURCE: Ga. Inst. Technol., Sch. Civ. Eng., Atlanta, GA, United

States; Comell Univ., United States, Univ. B. C., Canada

SOURCE: Joumal of Geotechnical Engineering vol. 118 no. 10 p.

1657-1661

DATE: 1992

COUNTRY OF PUBLICATION: United States

CODEN: JGENDZ ISSN: 0733-9410 REFS.: 7

SUBFILE: $B$

DOCUMENT TYPE: Serial BIBLIOGRAPHIC LEVEL: Analytic

ILLUSTRATIONS: illus.

LANGUAGE: English

NOTE: For reference to original see Sully, J. P. and Campanella, R. G., J.

Geotech. Eng., Am. Soc. Civ. Eng., Vol. 117, No. 7, July 1991

DESCRIPTORS: clastic sediments; clay; cone penetration tests; effects;

penetration tests; pore pressure ; pressure; sediments; soil mechanics

; stress

SECTION HEADINGS: 30 (Engineering Geology)

$18 / 9 / 30$

DIALOG(R)File 89:GeoRef

(C) 1996 American Geological Institute. All rts. reserv.

02036243 GEOREF NO.: 93-15746 BIBL. INDEX GEOLOGY NO.: 93-16942

TITLE: Seismic cone penetration test for evaluating liquefaction

potential under cyclic loading

AUTHOR(S): Robertson, P. K.; Woeller, D. J.; Finn, W. D. L.

CORPORATE SOURCE: University of Alberta, Department of Civil Engineering,

Edmonton, AB, Canada; ConeTec Investigations, Canada, University of

British Columbia, Canada

SOURCE: Canadian Geotechnical Joumal = Revue Canadienne de Geotechnique

vol. 29 no. 4 p. 686-695

DATE: 1992

COUNTRY OF PUBLICATION: Canada

CODEN: CGJOAH ISSN: 0008-3674 REFS.: 35

SUBFILE: $B$

DOCUMENT TYPE: Serial BIBLIOGRAPHIC LEVEL: Analytic

ILLUSTRATIONS: illus.; 2 tables

'ANGUAGE: English SUMMARY LANGUAGE: French

ISCRIPTORS: body waves; cone penetration tests; cyclic loading;

deformation; elastic waves; in situ; liquefaction; liquefaction potential

: loading: penetration tests; pore pressure : pressure; S-waves; soil 
mechanics; stress; testing; velocity

SECTION HEADINGS: 30 (Engineering Geology)

18/9/31

DIALOG(R)File 89:GeoRef

(c) 1996 American Geological Institute. All rts. reserv.

02036229 GEOREF NO.: 93-15732 BIBL. INDEX GEOLOGY NO.: 93-16941

TITLE: Estimating coefficient of consolidation from piezocone tests

AUTHOR(S): Robertson, P. K.; Sully. J. P.; Woeller, D. J.; Lunne, T.;

Powell, J. J. M.; Gillespie, D. G.

CORPORATE SOURCE: University of Alberta, Civil Engineering Department,

Edmonton, AB, Canada; INTEVEP, Venezuela, Conetec Investigations, Canada

- Norwegian Geotechnical Institute, Norway, Building Research

Establishment, United Kingdom, British Columbia Ministry of

Transportation and Highways, Canada

SOURCE: Canadian Geotechnical Joumal = Revue Canadienne de Geotechnique

vol. 29 no. 4 p. $539-550$

DATE: 1992

COUNTRY OF PUBLICATION: Canada

CODEN: CGJOAH ISSN: 0008-3674 REFS.: 45

SUBFILE: $B$

DOCUMENT TYPE: Serial BIBLIOGRAPHIC LEVEL: Analytic

ILLUSTRATIONS: illus.; 7 tables

LANGUAGE: English SUMMARY LANGUAGE: French

DESCRIPTORS: anisotropy; cone penetration tests; in situ; penetration

tests; permeability ; pore pressure ; pressure; soil mechanics;

testing

SECTION HEADINGS: 30 (Engineering Geology)

18/9/32

DIALOG(R)File 89:GeoRef

(C) 1996 American Geological Institute. All rts. reserv.

02034006 GEOREF NO.: 91-58993 BIBL. INDEX GEOLOGY NO.: 91-60316

TITLE: Determination of OCR in clays in piezocone tests using cavity

expansion and critical state concepts

AUTHOR(S): Mayne, Paul Wesley

CORPORATE SOURCE: Ga. Inst. Technol., Geotech. Div., Atlanta, GA, United

States

SOURCE: Soils and Foundations vol. 31 no. 2 p. 65-76

DATE: 1991

COUNTRY OF PUBLICATION: Japan

CODEN: SOIFBE ISSN: 0038-0806 REFS.: 39

SUBFILE: $B$

DOCUMENT TYPE: Serial BIBLIOGRAPHIC LEVEL: Analytic

ILLUSTRATIONS: 1 table; charts

LANGUAGE: English

MAJOR DESCRIPTORS: "soil mechanics

DESCRIPTORS: materials; properties; clay; cone penetration tests;

experimental studies; clastic sediments; materials, properties;

overconsolidated materials; pore pressure ; shear strength; 
consolidation

'ECTION HEADINGS: 22 (Engineering \& Environmental Geology)

$18 / 9 / 33$

DIALOG(R)File 89:GeoRef

(C) 1996 American Geological Institute. All rts. reserv.

02016109 GEOREF NO.: 93-01329 BIBL. INDEX GEOLOGY NO.: 93-03509

TITLE: Application of cone penetrometer technology in

hydrogeological investigations at the Savannah River Site (SRS), South

Carolina

AUTHOR(S): Van Pelt, Robert S.; Rossabi, Joseph; Kaback, Dawn S.; Jordan, James E.; Looney, Brian B.; Bergren, Chris L.

CORPORATE SOURCE: Westinghouse Savannah River Company, Aiken, SC, United

States

MONOGRAPH TITLE: Geological Society of America, 1992 annual meeting

AUTHOR(S): Anonymous

CONFERENCE TITLE: Geological Society of America, 1992 annual meeting

CONFERENCE LOCATION: Cincinnati, OH, United States

CONFERENCE DATE: Oct. 26-29, 1992

SOURCE: Abstracts with Programs - Geological Society of America vol. 24

no. 7 p. 35

DATE: 1992

COUNTRY OF PUBLICATION: United States

CODEN: GAAPBC ISSN: 0016-7592

'JBFILE: B

JOCUMENT TYPE: Abstract; Serial; Conference BIBLIOGRAPHIC LEVEL: Analytic

LANGUAGE: English

DESCRIPTORS: ground water; hydrogeology; organic materials; penetrometers;

pore pressure; potentiometric surface; Savannah River Plant; soils;

South Carolina; waste disposal; pressure; United States

SECTION HEADINGS: 22 (Engineering \& Environmental Geology)

18/9/34

DIALOG(R)File 89:GeoRef

(C) 1996 American Geological Institute. All its. reserv.

02000694 GEOREF NO.: 92-46412 BIBL. INDEX GEOLOGY NO.: $92-59556$

TITLE: Highway embankment construction across the Stratheam buried

valley

AUTHOR(S): Cochrane, G. A.; Carter, P. G.

CORPORATE SOURCE: Babtie Geotech., Glasgow, United Kingdom

MONOGRAPH TITLE: Proceedings of the 25th annual conference of the

Engineering Group of the Geological Soclety; Quatemary engineering

geology

EDITOR(S): Forster, A. (editor); Culshaw, M. G. (editor); Cripps, J. C.

(editor); Little, J. A. (editor); Moon, C. F. (editor)

CORPORATE SOURCE: Br. Geol. Surv., Nottingham, United Kingdom; Univ.

Sheffield, United Kingdom, Heriot-Watt Univ., United Kingdom, Sheffield

ity Polytech., United Kingdom

UONFERENCE TITLE: 25th annual conference of the Engineering Group of the

Geological Society 
CONFERENCE LOCATION: Edinburgh, United Kingdom

CONFERENCE DATE: Sept. 10-14, 1989

SOURCE: Engineering Geology Special Publications, Geological Society

vol. 7 p. 203-209

DATE: 1891

COUNTRY OF PUBLICATION: United Kingdom

REFS.: 3

SUBFILE: $B$

DOCUMENT TYPE: Serial; Conference BIBLIOGRAPHIC LEVEL: Analytic

ILLUSTRATIONS: illus.; sects.; sketch map .

LANGUAGE: English

MAJOR DESCRIPTORS: "Scotland; "highways; "soil mechanics

DESCRIPTORS: engineering geology; embankments; construction; settlement;

cone penetration tests; Great Britain; United Kingdom; Westem Europe;

Europe; Stratheam; Eam Valley; clay; clastic sediments; permeability :

shear strength; failures; pressuremeters; stability; monitoring

SECTION HEADINGS: 30 (Engineering Geology)

\section{8/9/35}

DIALOG(R)File 89:GeoRef

(c) 1996 American Geological Institute. All rts. reserv.

02000633 GEOREF NO.: 92-46349 BIBL. INDEX GEOLOGY NO.: 92-57005

TITLE: Cone penetrometer testing and discrete-depth groundwater sampling techniques; a cost-effective method of site characterization in a multiple-aquifer setting

AUTHOR(S): Zemo, D. A.; Pierce, Y. G.; Gallinatti, J. D.

CORPORATE SOURCE: Geomatrix Consultants, San Francisco, CA, United States

MONOGRAPH TITLE: Proceedings of the Sixth national outdoor conference on

Aquifer restoration, ground water monitoring, geophysical methods; a

conference and exposition

EDITOR(S): Stanley, Anita (editor)

CONFERENCE TITLE: Sixth national outdoor conference on Aquifer

restoration, ground water monitoring, geophysical methods; a conference

and exposition

CONFERENCE LOCATION: Las Vegas, NV, United States

CONFERENCE DATE: May 11-13, 1992

SOURCE: Ground Water Management vol. 11 p. 299-313

DATE: 1992

COUNTRY OF PUBLICATION: United States

ISSN: 1047-9023 REFS.: 3

SUBFILE: $B$

DOCUMENT TYPE: Serial; Conference BIBLIOGRAPHIC LEVEL: Analytic

ILLUSTRATIONS: illus.; sects.

LANGUAGE: English

MANOR DESCRIPTORS: "ground water, "pollution; "California

DESCRIPTORS: volatile organic compounds; environmental geology; Pacific

Coast; Westem U.S.; United States; cone penetration tests; aquifers;

applications; monitoring

SECTION HEADINGS: 22 (Engineering \& Environmental Geology) 
18/9/38

UIALOG(R)File 89:GeoRef

.) 1996 American Geological Institute. All rts. reserv.

01988768 GEOREF NO.: 92-30134 BIBL. INDEX GEOLOGY NO.: 92-49878

TITLE: An approach for prediction of compressibility and permeability

behaviour of sand bentonite mines

AUTHOR(S): Nagaraj, T. S.; Pandian, N. S.; Narasimha Raju, P. S. R.

CORPORATE SOURCE: Indian Inst. Scl., Dep. Clv. Eng., Bangalore, India

SOURCE: Indian Geotechnical Joumal vol. 21 no. 3 p. 271-282

DATE: 1991

COUNTRY OF PUBLICATION: India

CODEN: IGTJAG ISSN: 0046-8983 REFS.: 19

SUBFILE: $B$

DOCUMENT TYPE: Serial BIBLIOGRAPHIC LEVEL: Analytic

ILLUSTRATIONS: illus.; 3 tables

LANGUAGE: English

MANOR DESCRIPTORS: *soil mechanics

DESCRIPTORS: methods; cone penetration tests; sand; clastic sediments; prediction; permeability ; compressibility; deformation; behavior;

loading; seepage

SECTION HEADINGS: 30 (Engineering Geology)

18/9/39

DIALOG(R)File 89:GeoRef

) 1996 American Geological Institute. All rts. reserv.

01973661 GEOREF NO.: 92-31222 BIBL. INDEX GEOLOGY NO.: 92-30065

TITLE: Pore- pressure response due to penetration through layered

media

AUTHOR(S): Elsworth, Derek

CORPORATE SOURCE: Pa. State Univ., Dep. Miner. Eng., University Park, PA,

United States

SOURCE: Intemational Joumal for Numerical and Analytical Methods in

Geomechanics vol. 16 no. 1 p. 45-64

DATE: 1992

COUNTRY OF PUBLICATION: International

ISSN: 0363-9061 REFS.: 15

SUBFILE: $B$

DOCUMENT TYPE: Serial BIBLIOGRAPHIC LEVEL: Analytic

ILLUSTRATIONS: illuS.

LANGUAGE: English

MAJOR DESCRIPTORS: *soil mechanics

DESCRIPTORS: materials; properties; layered materials; pore pressure ;

Green function; monitoring; cone penetration tests; materials, properties

SECTION HEADINGS: 30 (Engineering Geology)

$18 / 9 / 41$

ALOG(R)File 89:GeoRef

(c) 1996 American Geological Institute. All rts. reserv. 
01970203 GEOREF NO.: 92-20040 BIBL. INDEX GEOLOGY NO.: 92-30271

TITLE: Recent advances in cone penetrometer measurements (software and hardware) and its application to liquefaction susceptibility

AUTHOR(S): Muraleetharan, Kanthasamy K.; Martin, Geoffrey R.; Hekma, Lucas $\mathrm{K}$.

CORPORATE SOURCE: Earth Technol. Corp., Long Beach, CA, United States MONOGRAPH TITLE: Proceedings; Recent advances In instrumentation, data acquisition and testing in soil dynamics

EDITOR(S): Bhatia, Shobha K. (editor); Blaney, Geoffrey W. (editor);

Univ. South. Calif., United States

CONFERENCE TITLE: Recent advances in instrumentation, data acquisition and testing in soll dynamics

CONFERENCE LOCATION: Orlando, FL, United States

CONFERENCE DATE: Oct. 21, 1991

SOURCE: Geotechnical Special Publication vol. 29 p. 33-48

DATE: 1991

COUNTRY OF PUBLICATION: United States

ISSN: 0895-0563 REFS.: 6

SUBFILE: $B$

DOCUMENT TYPE: Serial; Conference BIBLIOGRAPHIC LEVEL: Analytic

ILLUSTRATIONS: illus.; 1 table

LANGUAGE: English

MAJOR DESCRIPTORS: "California; "soil mechanics; "data processing

DESCRIPTORS: engineering geology; methods; cone penetration tests;

liquefaction; data acquisition; pore pressure ; Pacific Coast; Westem

U.S.; United States; Martinez Califomia; Foster City California;

computer programs; shear stress

SECTION HEADINGS: 30 (Engineering Geology)

18/9/42

DIALOG(R)File 89:GeoRef

(C) 1996 American Geological Institute. All rts. reserv.

01941139 GEOREF NO.: 91-56079 BIBL. INDEX GEOLOGY NO.: 91-60568

TITLE: The use of cone penetrometer testing for site characterization

AUTHOR(S): Voight, David S.; Cannestra, Robert B.

CORPORATE SOURCE: Donohue \& Assoc., Milwaukee, WI, United States

MONOGRAPH TITLE: Geological Society of America, North-central Section;

25th annual meeting

AUTHOR(S): Anonymous

CONFERENCE TITLE: Geological Society of America, North-central Section;

25th annual meeting

CONFERENCE LOCATION: Toledo, OH, United States

CONFERENCE DATE: Apr. 18-19, 1991

SOURCE: Abstracts with Programs - Geological Society of America vol. 23

no. 3 p. 65

DATE: 1991

COUNTRY OF PUBLICATION: United States

CODEN: GAAPBC ISSN: 0016-7592

SUBFILE: $B$

DOCUMENT TYPE: Abstract; Serial; Conference BIBLIOGRAPHIC LEVEL: Analytic

LANGUAGE: English

MAJOR DESCRIPTORS: *soil mechanics 
DESCRIPTORS: experimental studies; cone penetration tests; engineering geology; pressuremeters; water table; hydrogeology; soll sampling; methods; soil-structure interface; soil profiles

SECTION HEADINGS: 22 (Engineering \& Environmental Geology)

18/9/44

DIALOG(R)File 89:GeoRef

(C) 1996 American Geological Institute. All rts. reserv.

01773982 GEOREF NO.: 91-39061 BIBL. INDEX GEOLOGY NO.: 91-35226

TITLE: Effect of lateral stress on CPT penetration pore pressures

AUTHOR(S): Sully, J. P.; Campanella, R. G.

CORPORATE SOURCE: Univ. B.C., Dep. Civ. Eng., Vancouver, BC, Canada

SOURCE: Journal of Geotechnical Engineering vol. 117 no. 7 p.

1082-1088

DATE: 1991

COUNTRY OF PUBLICATION: United States

CODEN: JGENDZ ISSN: 0733-9410 REFS.: 36

SUBFILE: $B$

DOCUMENT TYPE: Serial BIBLIOGRAPHIC LEVEL: Analytic

ILLUSTRATIONS: Illus.; 1 table

LANGUAGE: English

MANOR DESCRIPTORS: "soil mechanics

DESCRIPTORS: methods; cone penetration tests; pore pressure; stress ; pressuremeters

ICTION HEADINGS: 22 (Engineering \& Environmental Geology)

18/9/45

DIALOG(R)File 89:GeoRef

(C) 1996 American Geological Institute. All rts. reserv.

01773059 GEOREF NO.: 91-32635 BIBL. INDEX GEOLOGY NO.: 91-35017

TITLE: Influence of placement method on the in situ density of hydraulic sand fillsdiscussion and reply

AUTHOR(S): Leonands, G. A.; Franz, R. J.; Sullivan, T. M.; Levergood; J.

C.; Sladen, J. A.; Hewitt, K. J.

CORPORATE SOURCE: Purdue Univ., Sch. Civ. Eng., West Lafayette, IN, United States; Hardy BBT, Canada, Can. Mar. Drill., Canada

SOURCE: Canadian Geotechnical Joumal = Revue Canadienne de Geotechnique

vol. 28 no. 2 p. $316-320$

DATE: 1991

COUNTRY OF PUBLICATION: Canada

CODEN: CGJOAH ISSN: 0008-3674 REFS.: 4

SUBFILE: $B$

DOCUMENT TYPE: Serial BIBLIOGRAPHIC LEVEL: Analytic

ILLUSTRATIONS: illus.

LANGUAGE: English

NOTE: For reference to original article by Sladen, J. A. and Hewitt, K. J., see Can. Geotech. J., Vol. 26, p. 453-466, 1989

WOR DESCRIPTORS: "Arctic Ocean; "soil mechanics

JESCRIPTORS: engineering geology; methods; cone penetration tests; sand ; clastic sediments; stress; pore pressure ; Beaufort Sea 
$18 / 9 / 46$

DIALOG(R)File 89:GeoRef

(c) 1996 American Geological Institute. All rts. reserv.
*Note: Requested Inter-Library Loan

for this document. $\quad 6 / 19 / 96$

01767211 GEOREF NO.: 91-27115 BIBL. INDEX GEOLOGY NO.: 91-29567

TITLE: Soil classification by the cone penetration test discussion and reply.

AUTHOR(S): Jeffries, M. G.; Davies, M. P.; Robertson, P. K.

CORPORATE SOURCE: Klohn Leonoff, Richmond, BC, Canada; Univ. Alberta, Canada

SOURCE: Canadian Geotechnical Journal = Revue Canadienne de Geotechnique

vol. 28 no. 1 p. 173-178

DATE: 1991

COUNTRY OF PUBLICATION: Canada

CODEN: CGJOAH ISSN: 0008-3674 REFS.: 8

SUBFILE: $B$

DOCUMENT TYPE: Serial BIBLIOGRAPHIC LEVEL: Analytic

ILLUSTRATIONS: Illus.; 2 tables

LANGUAGE: English

MANOR DESCRIPTORS: "soil mechanics

DESCRIPTORS: methods; cone penetration tests; classification; pore

pressure

SECTION HEADINGS: 22 (Engineering \& Environmental Geology)

18/9/47

DIALOG(R)File 89:GeoRef

(C) 1996 American Geological Institute. All rts. reserv.

01767202 GEOREF NO.: 91-27106 BIBL. INDEX GEOLOGY NO.: 91-29399

TITLE: Use and interpretation of a research dilatometer

AUTHOR(S): Campanella, R. G.; Robertson, P. K.

CORPORATE SOURCE: Univ. B.C., Dep. Civ. Eng., Vancouver, BC, Canada;

Univ. Alberta, Canada

SOURCE: Canadian Geotechnical Joumal = Revue Canadienne de Geotechnique

vol. 28 no. 1 p. 113-126

DATE: 1991

COUNTRY OF PUBLICATION: Canada

CODEN: CGJOAH ISSN: 0008-3674 REFS.: 27

SUBFILE: $B$

DOCUMENT TYPE: Serial BIBLIOGRAPHIC LEVEL: Analytic

ILLUSTRATIONS: illus.

LANGUAGE: English SUMMARY LANGUAGE: French

MAJOR DESCRIPTORS: "British Columbia; "soil mechanics

DESCRIPTORS: engineering geology; instruments; dilatometers; penetration tests; in situ; shear strength; earth pressure; pore pressure ; cone penetration tests; Westem Canada; Canada; Vancouver region; Sea Island ; Langley; sand; clastic sediments; Young's modulus; elastic constants; clay

SECTION HEADINGS: 22 (Engineering \& Environmental Geology) 
$18 / 9 / 48$

JIALOG(R)File 89:GeoRef

) 1996 American Geological Institute. All rts. reserv.

01762281 GEOREF NO.: 91-28742 BIBL. INDEX GEOLOGY NO.: 91-24433

TITLE: An analytical study of cone penetration test in clay

AUTHOR(S): Teh, C. I.; Houlsby, G. T.

CORPORATE SOURCE: Natl. Univ. Singapore, Fac. Eng., Singapore; Oxford

Univ., United Kingdom

SOURCE: Geotechnique vol. 41 no. 1 p. 17-34

DATE: 1991

COUNTRY OF PUBLICATION: United Kingdom

CODEN: GTNQA8 ISSN: 0016-8505 REFS.: 20

SUBFILE: B

DOCUMENT TYPE: Serial BIBLIOGRAPHIC LEVEL: Analytic

ILLUSTRATIONS: illus.; 3 tables

LANGUAGE: English SUMMARY LANGUAGE: French

MAWOR DESCRIPTORS: "soil mechanics

DESCRIPTORS: methods; cone penetration tests; clay; clastic sediments;

stress; pore pressure ; finite element analysis; statistical analysis;

plasticity; shear modulus; elastic constants; instruments

SECTION HEADINGS: 22 (Engineering \& Environmental Geology)

$18 / 9 / 50$

DIALOG(R)File 89:GeoRef

) 1996 American Geological Institute. All rts. reserv.

01760435 GEOREF NO.: 91-21533 BIBL. INDEX GEOLOGY NO.: 91-23217

TITLE: The engineering geophysical sounding method; principles, Instrumentation, and computerized interpretation

AUTHOR(S): Fejes, Imre; Josa, Emo

CORPORATE SOURCE: Eotvos Lorand Geophys. Inst. Hung., Budapest, Hungary

MONOGRAPH TITLE: Geotechnical and environmental geophysics; Volume 2,

Environmental and groundwater

EDITOR(S): Wand, Stanley H. (editor)

SOURCE: Investigations in Geophysics vol. 5 p. 321-331

DATE: 1991

COUNTRY OF PUBLICATION: United States

SUBFILE: $B$

DOCUMENT TYPE: Serial BIBLIOGRAPHIC LEVEL: Analytic

ILLUSTRATIONS: illus.; 1 table; sects.

LANGUAGE: English

MAJOR DESCRIPTORS: *Hungary; "well-logging

DESCRIPTORS: geophysical surveys; radioactivity; gamma -ray methods; sounding; techniques; Central Europe; Europe; engineering geophysical sounding; cone penetration tests

SECTION HEADINGS: 20 (Geophysics, Applied) 


\section{APPENDIX A.3 UNIVERSITY OF FLORIDA PRELIMINARY LITERATURE SEARCH}




\section{FAX MESSAGE}

To: Neil Johnson

Parsons Environmental

Savannah River, South Carolina

Message:

Here are some examples of the types of references that appeared in a preliminary literature search on the use of a cone penetrometer in environmental applications. There were about 80 references reported, but only a few seerned pertinent to your application.

If I can be of further service, please contact me at (352) 377-9567 or by e-mail at afn02472@afn.org to discuss the services available and their charges. 
Authors: Campanella, R. G.

Title: Cone penetration test for site characterization.

FOUND DN: Proceedings of the International Conference on Soil Mechanics and Foundation Engineering v 1. Publ by A.A. Balkema, Rotterdam, Neth. p 205-210 Conference: Proceedings of the 12th International Conference on Soil Mechanics and Foundation Engineering Rio de Janeiro, $\mathrm{Br}$ 19890813-19890818

Publication year: 1989

Abstract: Several statistical methods have been applied to Cone Penetrometer Test (CPT) data in order to better characterize a soil stratum. While trend analysis is used to better characterize soil property variation and identify sublayers within a soil stratum, the traditional method of identifying layers using the friction ratio method is compared to a method based on the scale of fluctuation of a sublayer. The random measurement error in data from various test methods bas been obtained using two different techniques and a comparison has been made for those obtained from these methods. A method of two dimensional soil property interpolation considering correlation between different points is presented and applied to some data obtained from the CPT. The need for the consideration of the variability of a soil profile prior to determining the optimum sampling spacing is also bighlighted. (Author abstract) Refs.

Authors: Knowlton, Robert

Strong, Warren

Onsurez, Jackie

Rogoff, Eric

Title: Advances in hydrologic measurement techniques: in-situ and cone penetrometer applications

FOUND IN: Proceedings of SPIE - The International Society for Optical Engineering y 2504 1995. Society of Photo-Optical Instrumentation Engineers, Bellingham, WA, USA p 592-599

Conference: Environmental Monitoring and Hazardous Waste Site Remediation Munich, Ger 19950619

Sponsor(s): SPIE - Int Soc for Opt Engineering, Bellingham, WA USA

Publication year: 1995

Abstract: Sandia National Laboratories has developed sensors allowing real-time, continuous measurement of hydrogeologic parameters for use in 
contaminant transport modeling, risk assessments, and the optimization of remedial alternatives (e.g., soil venting, bioremediation). These sensor packages have been engineered into a cone penetrometer push technology, in addition to their stand-alone deployment. The sensor packages include a time domain reflectometry (TDR) sensor to quantify volumetric soil moisture content and a fiber optic relative humidity (RH) sensor to quantify capillary pore pressure in unsaturated soils. Results indicate that TDR probes having optimal specifications yield measurements representative of the formation. TDR probes show better accuracy than neutron and capacitance probes. $R H$ sensors responded quilinly be the lakeratory, but rodooign will he nes:assary to make the housing suitable for 'real-time' cone penetrometer applications. Sandia deployed the TDR and RH probes along with geotechnical sensors on a cone penetrometer rig. Data allowed three-dimensional analysis of lithologic control of soil water migration at a level of detail greater than possible using conventional methods. In addition, the TDR design has been employed in a down-hole logging configuration for tortine monitoring in access tubes, as a non-nuclear alternative to a neutron probe. The cone penetrometer with the TDR probe represents a significant technological advance in site assessment capabilities.

Authors: Apitz, Sabine E.

Theriault, Gregory A.

Lieberman, Stephen $\mathrm{H}$.

Title: Optimization of the optical characteristics of a fiber-optic-guided laser fluorescence technique for the in-situ evaluation of fuels in soils.

FOUND IN: Proceedings of SPIE - The International Society for Optical Engineering v 1637. Publ by Int Soc for Optical Engineering, Bellingham, WA, USA. p 241-254

Conference: Environmental and Process Monitoring Technologies Los Angeles, CA, USA $19920120-19920122$

Sponsor(s): SPIE - Int Soc for Opt Engineering, Bellingham, WA, USA Publication year: 1992

Abstract: We have developed a system for the in situ determination of petroleum bydrocarbons in soils. This system uses a pulsed $N / / 2$ laser coupled with a photodiode array detector to make fluorescent measurements via optical fibers. The measurement is made through a sapphirewindow on a probe that is pushed into the ground with a truck-mounted cono penetrometer. This is the first reported direct optical detector for contaninants in soils. Remote in situ fluorometric measurements over long lengths of optical fibers give rise to several complications not encountered with conventional laboratory fluorescence 
measurements. The effects of these issues on the calibration and response of the optical detector are discussed. While we specifically discuss calibration of measurements of diesel fuel marine (DFM) by UV fluorescence, we believe that the calibration techmiques and optical issues we are addressing aro germane to most if not all in situ optical measurements of contaminants in soils. In order to improve the in situ fluorescent quantitation of petroleum hydrocarbons, we have calibrated the fluorescent response of fuels as a function of soil type and conditions. The fluorescent response of DFM varies by an order of magnitude or more as a function of soil type. Experiments to determine the causes of this variability have shown that the controlling variable is surface area of the substrate, although there are secondary effects as a function of grain size, mineralogy, and degree of soil aggregation. We have found that normalizing contaminant concentration to available soil surface area allows for a much more predictable response factor. It should be noted, however, that the variation in fluorescent response of DFM in three of four EPA soils tested is relatively small, with only one showing a large divergence. Soils with mixtures of grain types and sizes fall in a relatively tight response range, while soils such as very pure sands or clays diverge significantly. Preliminary studies on the effects of moisture content on the fluorescent response of DFM in solls suggest that the addition of water to the matrix begins to exclude DFM from the grain surfaces, forcing the fluorophore into the grain interstices, and greatly decreasing the difference in fluorescent response between soil types. The moisture effect is the smallest in mixtures of sand and clay. We are cutrently developing specific fluorescence calibration algorithms as a function of soll type, and correlating actual soil types to soil classifications derived from cone penetrometer strain gauge data. 25 refs. 


\section{APPENDIX B CORE EXAMINATION NOTES}




\section{THIS PAGE INTENTIONALLY LEFT BLANK}




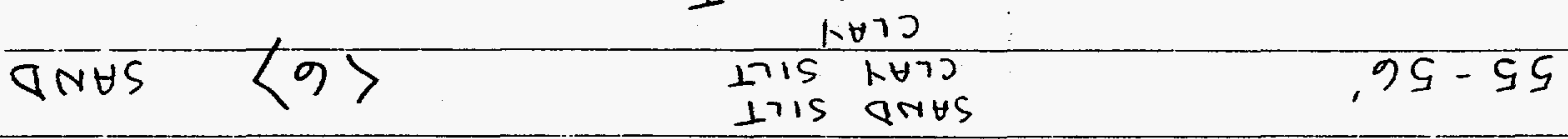

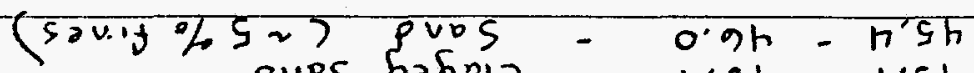

$$
\begin{aligned}
& \begin{array}{l}
\text { puos hofoli - h.sh }-1.5 h \\
\text { hold kPUOS - } 1.5 h-0.5 h
\end{array} \\
& 52.60104 t .1 \text { t2u.ts!p } \varepsilon \text { punof - }
\end{aligned}
$$

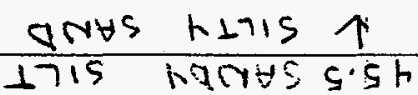

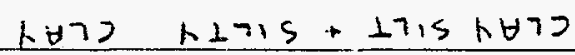$$
\wedge \forall 72
$$
बत्S.
$\langle 9\rangle 1 \forall 70 k+715+17151 \forall 73$
9h-Sh

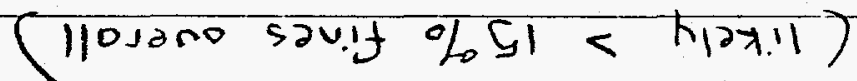

ivg \% haon sasual - fop hpuos/puos hafol.

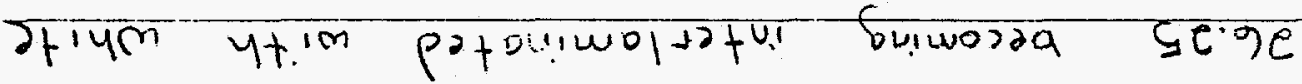

of o.ge wasf puos un.pow at aulf vot punof -

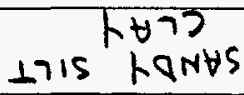

$$
\begin{aligned}
& \text { QतUS hLרIS }
\end{aligned}
$$
RNES
रदा h.me-0.ne ants
Le-IC

\begin{tabular}{|c|c|c|c|c|}
\hline QNits & $\langle 01\rangle$ & $n \forall 75$ & , न1-डा & \\
\hline .72506507 & paw \% & ग5SP $1 d J$ & $101 d^{2}+47$ & \\
\hline & & & $71 \perp 0 m 5 / 5-5 \pm 0$ & $\begin{array}{l}\text { Henr } \\
\text { Hen }\end{array}$ \\
\hline
\end{tabular}

$$
\text { , } 9 \text {. } 1 \text { of } \varepsilon \text {. } 91 \text { to suग }
$$

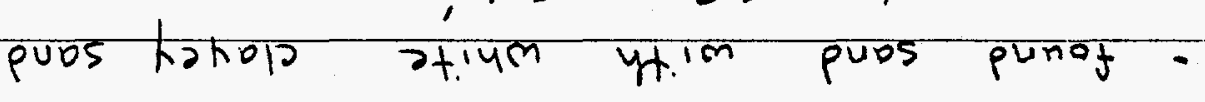




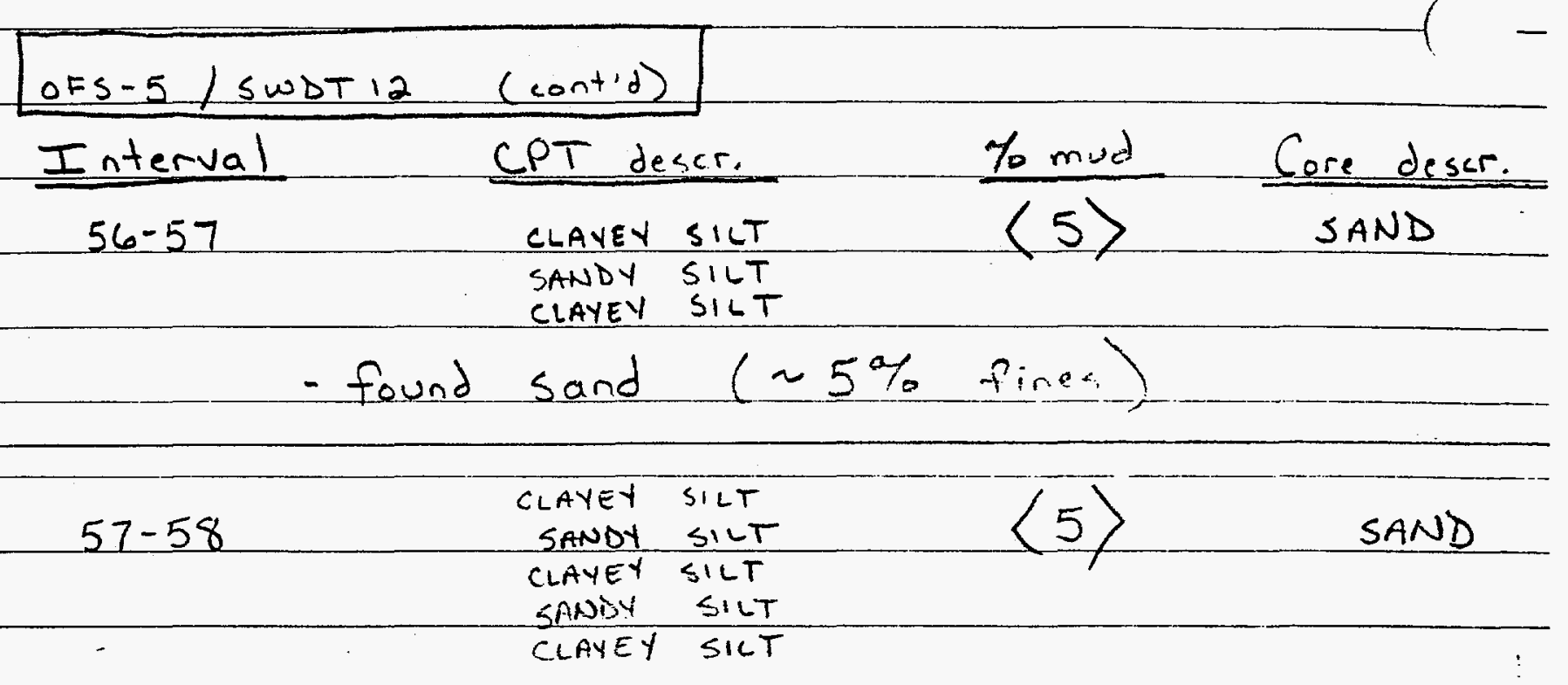

- found sand - fine-to-medium (well-sorted) $(-5 \%$ fines $)$

58-59 _ CLAVEY SILT/SILTY CLAY $\langle 6\rangle$

- found sand ( $26 \%$ fines) with zones of fines from 58.8 to 59.0

$59-60$

CLAYEY SILT

SANDY SILT
CLAYEY SILT

- found sand ( $25 \%$ fines)

$60-61$

CLAYEY SILT / SILTY CLAY

$\langle 4\rangle$

SAND

- found sand - medium with silty zones ( $\sim 4 \% \operatorname{sand})$

$78-79$

SANDY

SILTY SAND

SANDY SILT SAN ( 


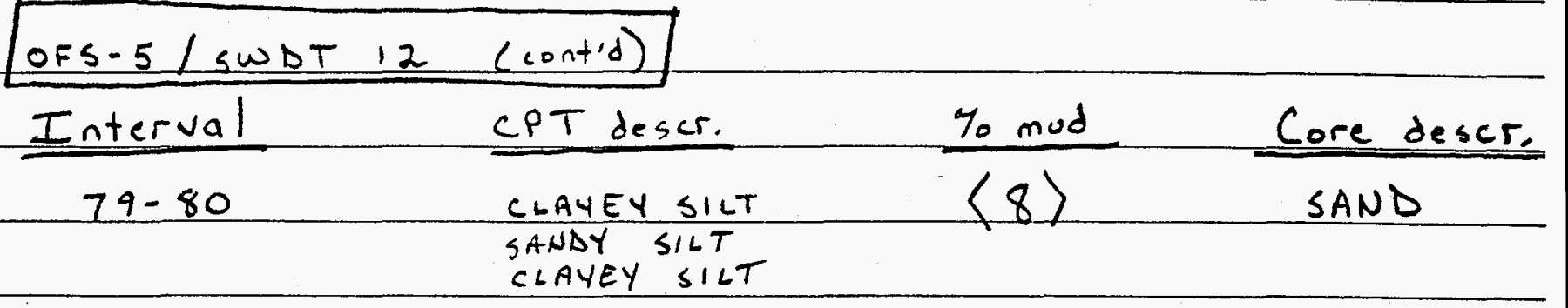

- found sand - fine to coarse ( $18 \%)$

$$
\text { 80-81 CLAVEY SILT/ SILTY CLAY }\langle 6\rangle \text { SAND }
$$

- found Sand

$$
81-82
$$

$82-83$
CLAYEY SILT

SANDY SILT

SILTY SAND
SAND $\langle 6\rangle \quad$ SAND

- found sand

$\underline{I}$

SAND

SILTY SAND

- found sand

$83-84$
SILTY

SAND

CLAY
SOUP
5) SAND

$\frac{\langle 5\rangle \quad \text { SAND }}{-\langle 10\rangle \quad \text { SAND }}$

- found sand wa organics increasing in fines at bottom

- from 83.7 to $84.0 \sim 15 \%$ fines

CLAYEY SILT/ SILTY CLAY

$\langle 7\rangle$ SAND

- found fine sand w/ organics

- increasing in fines

(3) 


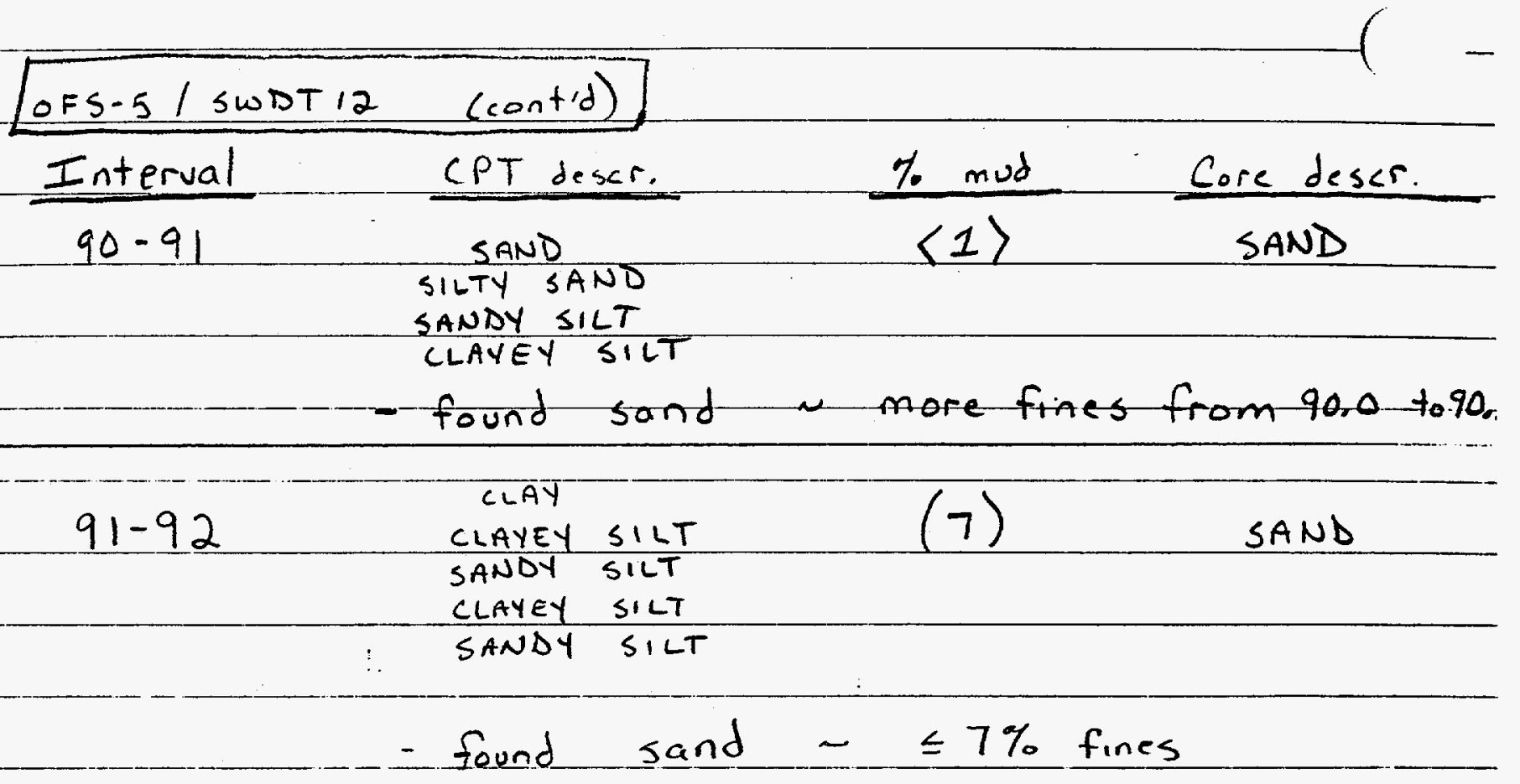

fine sand wi heavy minerals

(4) 


$$
B G T-03
$$

Interval

$114-115$

CPT descr.

CLAYEY SILT/

$\%$ mud

Core.deser.

CLAYEY SILT

$\langle 3\rangle$

SAND

- found sand $\approx 3 \%$

$122-123$

CLAYEY SILT/ SILTY CLAY

$\langle 5\rangle$

SAND

- found sand - silty > $>$ \% 10-15\%. Fines

(silicified gastropod)

$123-124$

CLAYEY SILT/ SILTY CLAY

$\langle 3\rangle$

SAND

found sand - fine -tar medium

$B G T-05$

$10-11$

CLAY

CLAYEY SILT

SANDY SILT

$\langle 20\rangle \quad S A N D$

- found sand - medium to coarse w/ inter laminated fines (sandy clay)

$12-13$ SILTY SAND

$\langle 85\rangle \quad$ CLAY

- found clay

$13-14$

SAND SILT
CLAYEY SILT/ SILTY CLAY $\langle 80\rangle$ CLAY

- found clay

$14-15 \quad$ CLAY $\quad$ found clay

$\langle 90\rangle \quad$ CLAY

(5) 
$R P C-1$

Interval

CPT defer.

$\%$ mud

Core desert.

$10-11$

CLAY

$\langle 25\rangle$ CLAYEY SAND

- found clayey sand $\sim 25 \%$

$11-12$

CLAY

$\langle 25\rangle$

CLAYEY SAND

- found clayey sand $225 \%$

$12-13 \quad$ CLAY

$\langle 25\rangle$

CLAYEY! SAND

- found clayey sand

$18-19$

SILTY SAND
SANDY SILT
SAND
found clayey sand

$\langle 30\rangle$

CLAYEY

SAND

$19-20$ $\langle 15\rangle$

SAND

- found sand - some fines

$20-21$

SANDY SILT

CLAYEY SILT $\langle 20\rangle$

SAND

- found sand $20 \%$
CLAY

$\langle 15\rangle$

- found sand $215 \%$

$24-25$

CLAY

$\langle 40\rangle$

SAND

- found clayey sand $240 \%$

(10) 


$$
R P C-1\left(\operatorname{con} t^{\prime} d\right)
$$

$\frac{\text { Interval }}{30-31} \frac{\text { CPT desC, }}{\text { CLAY }} \frac{\% \text { mud }}{\langle 45\rangle} \frac{\text { Core odes }}{\text { CLAYEY }}$
- found clayey sand (appears $\sim 45 \%$ )

$$
\text { - (laboratory) } 30-30.5=31.5 \%<\# 200 \quad K=1.1 \times 10^{-6} \mathrm{~cm} / \mathrm{sec}
$$

$$
\begin{array}{llll}
110-111 & \text { SAND } & \langle 4\rangle & \text { SAND } \\
111-112 & \text { SAND } & \langle 4\rangle & \text { SAND }
\end{array}
$$

- found sand - coarse $(\sim 4 \%)$

$112-113$
SAND

CLAY $\langle 5\rangle \quad$ SAND

- found sand $\sim<5 \%$

$113-114$

CLAYEY SILT

$\langle 7\rangle$

SAND

- found sand - some bands of purple silt

$147-148$

SILTY SAND

$\langle 85\rangle$

CLAY

- found sand <20\% $147-147.5$

clay $\quad 147.5-148$

- 2 distinct lithologies

(7) 
8/2/96 Gunsite Core Depository

JWH

Core LCO $\$ 5$ NL

NA

CPTL-7

CPT desc.

$\frac{\% \text { mud }}{\langle 10\rangle}$

Core descr.

Interval

$$
\begin{aligned}
& \text { CLAY } \\
& \text { SILT/ MI } \\
& \text { CLAY }
\end{aligned}
$$$$
\text { SAND }
$$

- found clayey sand from 22.0-22.5 sand $\sim 15 \%$ from $22.5-23.0$

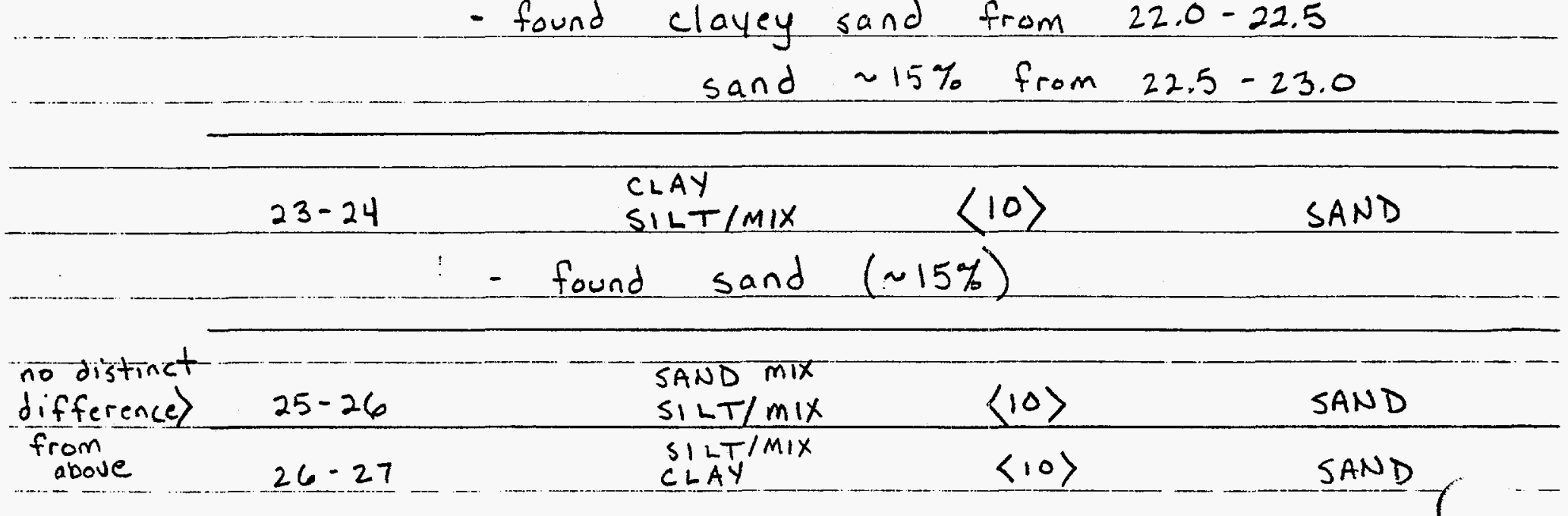

- found sand - red from 26.0 to 26.5

sand - tan from 26.5 to 27.0

$27-28$ CLAY SILT/MIX $\langle 10\rangle$ SAND

- found sand - mottled tan 4 red

$43-44$

SAND

$\langle 1\rangle$

SAND

- found sand - well-sorted medium to coarse $(-1 \%)$

$44-45$ SAND/ SAND mix

$\langle 0\rangle$

SAND

- found sand

$55-56$

SAND $m I X$

LI

SAND

SLAT'

- found sand

(8) 
CPT L-T Core LCO 05 DL (contd)

$\frac{\text { Interval }}{56.57} \frac{\text { CPT descr. }}{\text { CLAYS }} \frac{\% \text { mud }}{\langle 2\rangle} \frac{\text { Core desc. }}{\text { ORGANICS }}$

- found sand

$57-58$

ORGANICS

CLAYS

SILT/MIX

$\langle 15\rangle \quad$ SAND

SAND MIX

SAND

- found sand - more fines 57.5-58

$58-59$

SAND

$\langle 25\rangle$

CLAYEY SAN

- found clayey sand wt organics

(9) 
CPT L.12 Core LCOOO

$\frac{\text { Interval }}{37-38} \frac{\text { CPT descr. }}{\text { CLAY }} \frac{\% \text { mud }}{\langle 30\rangle}$ CLAYEY SANE

- four - : $14 y$ sand

* from 36.0 to 36.5 sandy day to clay

$38-39$

CLAY

〈30) CLAYEY SAND

- found clayey sand - fine to medium grained

$39-40$

CLAY

SILT MIX

$\langle 30\rangle$ CLAYEY SAND

- found some as above

$45-46$

CLAY

$\langle 20\rangle$

SAND

- found clayey sand from 45.0 to 45.2

fine sand from 45.2 to 46.0

$52-53$

SAND

$\langle 3\rangle$

SAND

- found sand with little to no fines

$68-70$

SAM

SiN

CLAY

SILT

* Core log had this as $N$ but 65-67 was -NR, $67-70=100 \%$ recovery $\langle 20\rangle$ SAND

- found sand $\sim 20 \%$ wal zones of fines $70-7.1$

CLAY

SILT $\langle 3\rangle$

"flowing"

(10) 


\section{APPENDIX C CORE AND GEOPHYSICAL LOGS FOR LOCATIONS BGT-11 AND BGT-20}




\section{THIS PAGE INTENTIONALLY LEFT BLANK}




\section{BGT-11}

COMPAHY

HELL

LOCATION/FIELO

COUHTY

STATE

SECTION

\section{DATE}

DEPTH DRILLER

LOG BOTTOII

LOG TOP

CASING DRILLER

5 G TYPE : -

C.... THICKNESS: -

BIT SIZE : 5

MAGHETIC OECL: : -

MAJRIX DENSITY : -

FLUID OEHSITY : -

MEUTRON MATRIX : -

REMARKS :

$0-178^{\circ} 5^{*}$ CORE HOLE $178-179^{\circ}$ PUSHED SHELBY TUBE

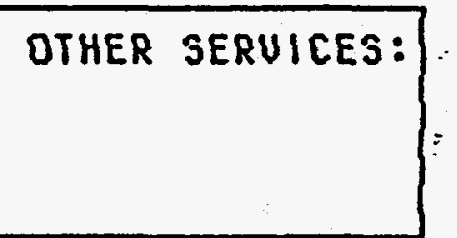

TOWNSHIP

PERMANENT DATUM : -

ELEU. PERM. DATUM:

LDE MEGSURED FROM: GL

DRL MEASURED FROM: -

LOGGING UHIT : 426

FIELD OFFICE : JACKSON

RECORDED BY

: RIZER

BOREHOLE FLU1D: MUD/H2O

RM

RM TEMPERATURE : -

MATRIX DELTA T : -

FLUID OELTA $T$ : -
RAMGE :

ELEUATIONS

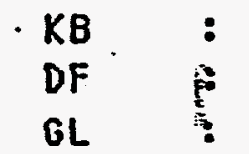

$-$

ALL SERUICES PROUIDED SUBJECT TO STANDARD TERMS AND CONDITIONS

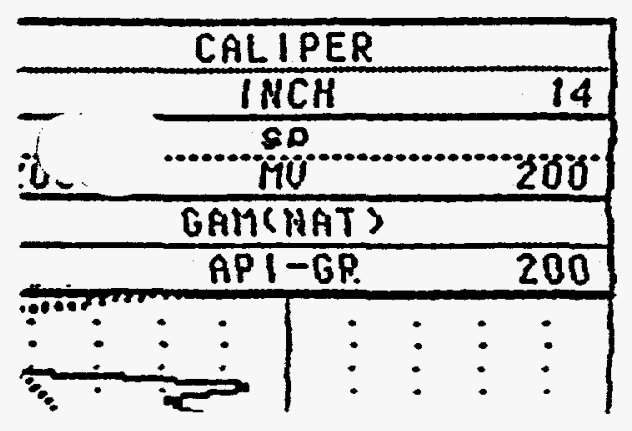

\begin{tabular}{|c|c|c|}
\hline \multicolumn{3}{|c|}{ RES } \\
\hline 0 & $\mathrm{OHM}$ & 251 \\
\hline ס & $\begin{array}{l}\text { ESSGAH2 } \\
\text { DHM-M }\end{array}$ & $5 \overline{0}$ \\
\hline & $E S(16 N)$ & \\
\hline 0 & OHM-M & 50 \\
\hline & & \\
\hline
\end{tabular}



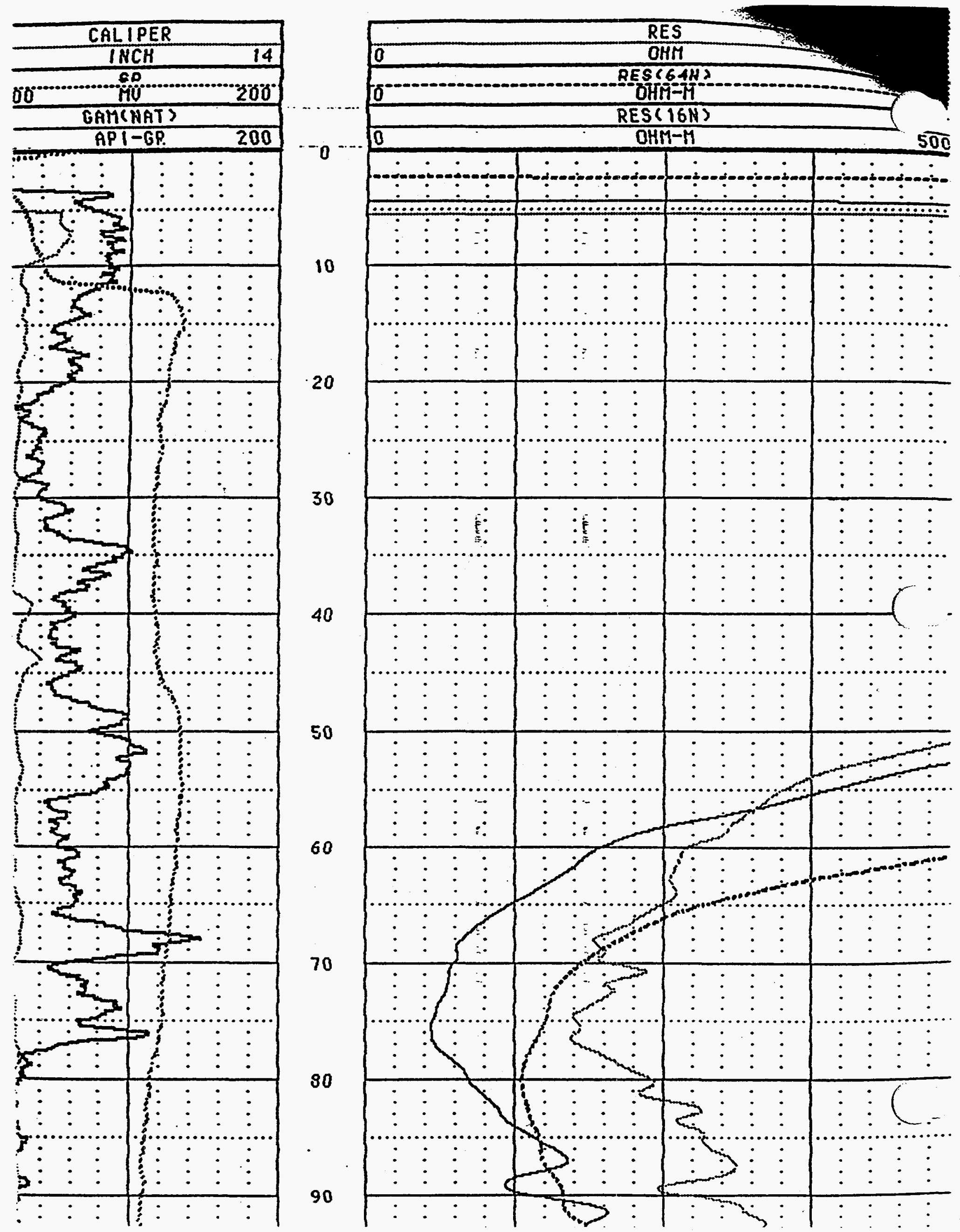


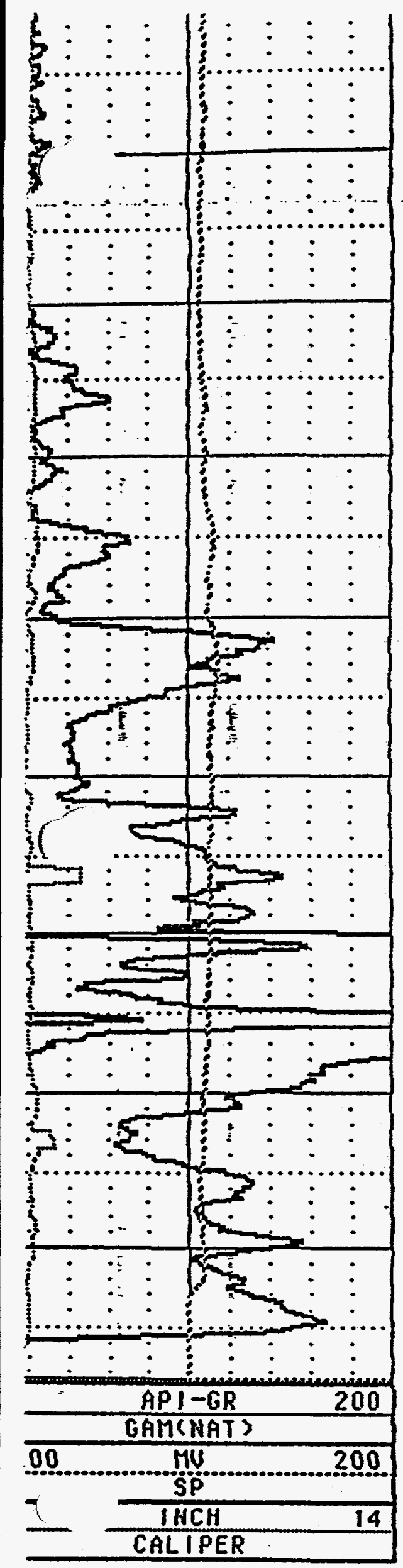

100

110

120

130

140

150

160

170

179

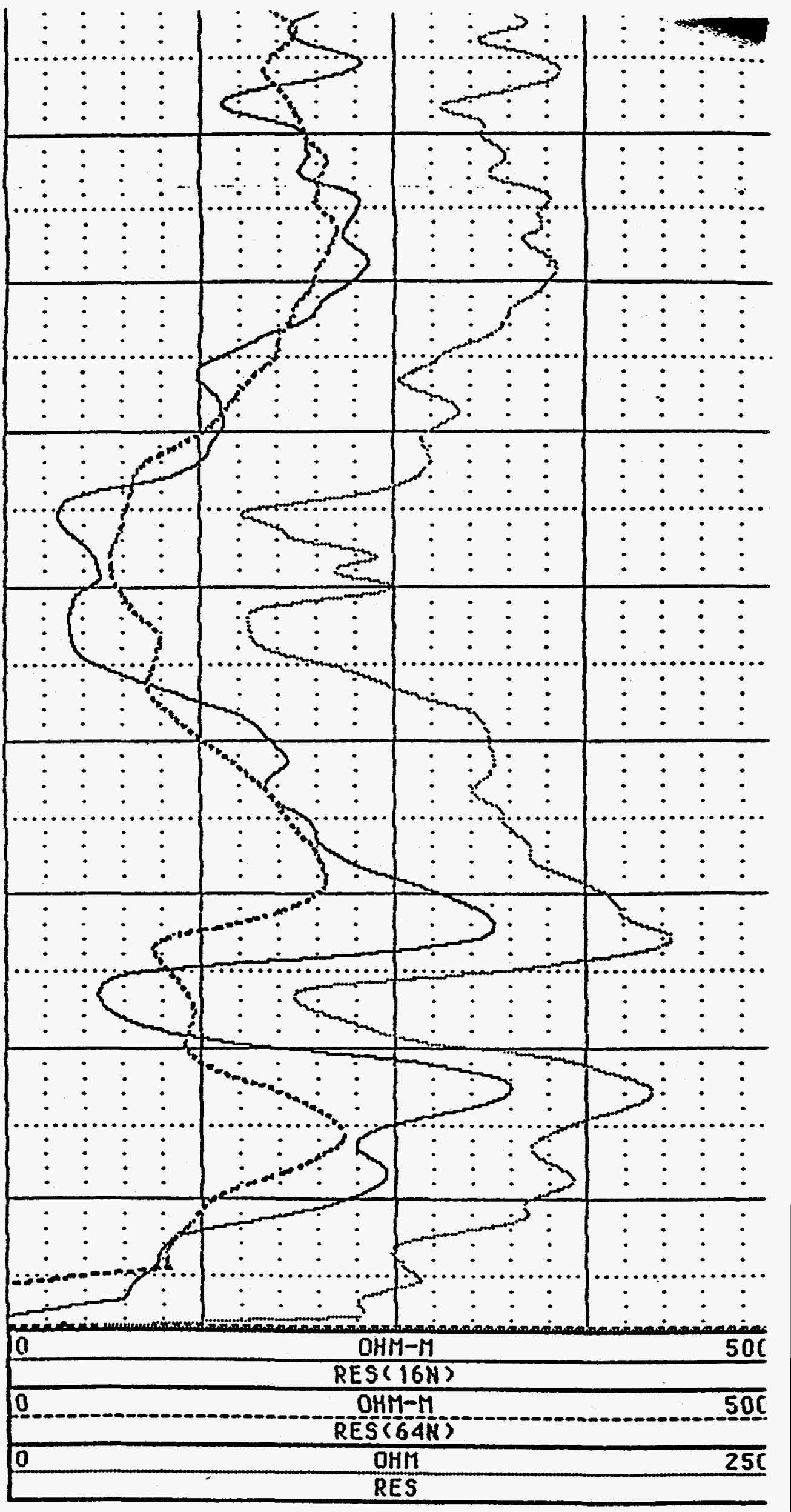

$8 G T-11 \quad 12 / 01 / 94 \quad 263$ 


\section{EA NO SCR DEPTH BEC IND COLOR STRUCTUR \%GR \%SD \%MD MX MD B \%CC \%CS \%CM \%CMT\%CAR NAMR SO \%POR TYPE \%MUS \%GLA \%LIG \%SUL H FOSSILS}

\begin{tabular}{|c|c|c|c|c|c|c|c|c|c|c|}
\hline$T 11$ & 1 & 0 & & & & & & & & \\
\hline$T 11$ & 2 & 0 & & & & & & & & \\
\hline$T 11$ & 3 & 0 & & & & & & & & \\
\hline r 11 & 4 & 0 & & & & & & & & \\
\hline$[11$ & $s$ & 0 & & & & & & . & & \\
\hline$r 11$ & 6 & 0 & & & & & & & & \\
\hline 111 & 7 & 0 & & & & & & & & \\
\hline$: 11$ & 8 & 0 & & & & & & & & \\
\hline$: 11$ & 9 & 0 & & & & & & & & \\
\hline$\because 11$ & 10 & 0 & & & & & & & & \\
\hline 111 & 11 & & 2 & MREBR & 0.1 & 75 & 25 & GR & $F$ & 3 \\
\hline$\cdot 11$ & 12 & & 2 & MREBR & 0.1 & 90 & 10 & GR & $\mathbf{M}$ & 3 \\
\hline$\cdot 11$ & 13 & & 2 & MREBR & 0.1 & $90^{\circ}$ & 10 & GR & $M$ & 3 \\
\hline$\cdot 11$ & 14 & & 2 & MREBR & 0.1 & 90 & 10 & $\mathbf{O R}$ & $\mathbf{M}$ & 3 \\
\hline 11 & 15 & & 2 & MREBR & 0.1 & 90 & 10 & $G R$ & $\mathbf{M}$ & 3 \\
\hline 11 & 16 & $s$ & 2 & MREBR & 0.1 & 92 & 8 & OR & $\mathbf{M}$ & 3 \\
\hline 11 & 17 & & 2 & MREBR & 0.1 & 92 & 8 & OR & $M$ & 3 \\
\hline 11 & 18 & & 2 & MREBR & 0.1 & 92 & 8 & GR & $\mathbf{M}$ & 3 \\
\hline 11 & 19 & & 2 & LREBR & 0.1 & 92 & 8 & GR & $\mathbf{M}$ & 3 \\
\hline 11 & 20 & & 2 & LREBR & 0.1 & 92 & 8 & OR & $\mathbf{M}$ & 3 \\
\hline 11 & 21 & & 2 & LREBR & 0.1 & 92 & 8 & GR & $\mathbf{M}$ & 3 \\
\hline 11 & 22. & & 2 & LREBR & 0.1 & 90 & 10 & GR & $M$ & 3 \\
\hline 11 & 23 & & 2 & LREBR & 1 & 89 & 10 & $\mathbf{G R}$ & $\mathbf{M}$ & 3 \\
\hline 11 & 24 & & 2 & LREBR & 0.1 & 90 & 10 & GR & $\mathbf{M}$ & 3 \\
\hline 11 & 25 & & 2 & LREBR & 1 & 89 & 10 & GR & $M$ & 3 \\
\hline 11 & 26 & & 2 & LREBR & 0.1 & 90 & 10 & GR & $M$ & 3 \\
\hline $1 !$ & 27 & & 2 & LREBR & 0.1 & 85 & is & OR & M & 3 \\
\hline 11 & 28 & & 2 & LREBR & 0.1 & 85 & 15 & GR & $M$ & 3 \\
\hline 11 & 29 & & 2 & LREBR & 0.1 & 85 & 15 & GR & $M$ & 3 \\
\hline 11 & 30 & & 2 & LREBR & 0.1 & 85 & 15 & $G R$ & $\mathbf{M}$ & 3 \\
\hline 11 & 31 & & 2 & LREBR & 0.1 & 80 & 20 & GR & $\mathbf{M}$ & 3 \\
\hline 11 & 32 & & 2 & LREBR & $1^{\circ}$ & 84 & 15 & GR & $M$ & 3 \\
\hline 11 & 33 & & 2 & LREBR & 0.1 & 85 & 15 & OR & $M$ & 3 \\
\hline 11 & 34 & & 2 & LREBR & 0.1 & 85 & 15 & OR & $M$ & 3 \\
\hline 11 & 35 & 6 & 2 & LREBR & 0.1 & 85 & is & OR & $\mathbf{M}$ & 3 \\
\hline 11 & 36 & & 2 & LREBR & 0.1 & 75 & 25 & OR & $M$ & 3 \\
\hline 11 & 37 & & 2 & LREBR & 0.1 & 75 & 25 & OR & $\mathbf{M}$ & 3 \\
\hline 11 & 38 & & 2 & LREBR & 0.1 & 75 & 25 & OR & $\mathbf{M}$ & 3 \\
\hline 11 & 39 & & 2 & LREBR & 0.1 & 80 & 20 & GR & $\mathbf{F}$ & 3 \\
\hline iI & 40 & & 2 & LREBR & 0.1 & 80 & 20 & OR & $\mathbf{p}$ & 3 \\
\hline 11 & $4 !$ & & 2 & DYEOR WSPLONCL & 0.1 & 70 & 30 & OR & VF & 3 \\
\hline 11 & 42 & & 2 & LYEOR & 0.1 & 75 & 25 & OR & $\mathbf{V F}$ & 3 \\
\hline 11 & 43 & & 2 & LONOY & 0.1 & 75 & 25 & GR & VF & 3 \\
\hline 11 & 44 & & 2 & LONOY & 0.1 & 75 & 25 & OR & $\mathbf{P}$ & 3 \\
\hline
\end{tabular}

\begin{tabular}{|c|c|c|c|c|c|c|c|}
\hline CLSD & P & $\mathbf{P}$ & BP & 0.1 & 0 & 0 & 0 \\
\hline$S D$ & $\mathbf{M}$ & $M$ & BP & 0.1 & 0 & 0 & 0 \\
\hline$S D$ & $M$ & $M$ & BP & 0.1 & 0 & 0 & 0 \\
\hline$S D$ & $\mathbf{M}$ & $M$ & BP & 0.1 & 0 & 0 & 0 \\
\hline$S D$ & $M$ & $\mathbf{M}$ & $\mathrm{BP}$ & 0.1 & 0 & 0 & 0 \\
\hline$S D$ & $\mathbf{M}$ & $\mathbf{M}$ & BP & 0.1 & 0 & 0 & 0 \\
\hline SD & $\mathbf{M}$ & $\mathbf{M}$ & $B P$ & 0.1 & 0 & 0 & 0 \\
\hline SD & $M$ & $\mathbf{M}$ & $B P$ & 0.1 & 0 & 0 & 0 \\
\hline SD & $\mathbf{M}$ & $\mathbf{M}$ & BP & 0.1 & 0 & 0 & 0 \\
\hline SD & $M$ & $M$ & BP & 0.1 & 0 & 0 & 0 \\
\hline SD & $M$ & $M$ & $\mathrm{BP}$ & 0.1 & 0 & 0 & 0 \\
\hline$S D$ & $M$ & $M$ & BP & $0.1^{\circ}$ & 0 & 0 & 0 \\
\hline SD & $\mathbf{M}$ & $M$ & BP & 0.1 & 0 & 0 & 0 \\
\hline SD & $M$ & $M$ & BP & 0.1 & 0 & 0 & 0 \\
\hline SD & $M$ & $M$ & $\mathrm{BP}$ & 0.1 & 0 & 0 & 0 \\
\hline$S D$ & $\mathbf{M}$ & $M$ & BP & 0.1 & 0 & 0 & 0 \\
\hline SD & $M$ & $\mathbf{M}$ & BP & 0.1 & 0 & 0 & 0 \\
\hline SD & $M$ & $M$ & $\mathrm{BP}$ & 0.1 & 0 & 0 & 0 \\
\hline SD & $\mathbf{M}$ & $M$ & BP & 0.1 & 0 & 0 & 0 \\
\hline SD & $M$ & $M$ & $\mathrm{BP}$ & 0.1 & 0 & 0 & 0 \\
\hline SD & $M$ & $\mathbf{M}$ & BP & 0.1 & 0 & 0 & 0 \\
\hline$S D$ & $M$ & $\mathbf{M}$ & BP & 0.1 & 0 & 0 & 0 \\
\hline$S D$ & $\mathbf{M}$ & $M$ & BP & 0.1 & 0 & 0 & 0 \\
\hline SD & $M$ & $M$ & BP & 0.1 & 0 & 0 & 0 \\
\hline SD & $M$ & $M$ & $\mathrm{BP}$ & 0.1 & 0 & 0 & 0 \\
\hline CLSD & $\mathbf{P}$ & $\mathbf{p}$ & $B P$ & 0.1 & 0 & 0 & 0 \\
\hline CLSD & $\mathbf{P}$ & $P$ & BP & 0.1 & 0 & 0 & 0 \\
\hline CLSD & $\mathbf{P}$ & $\mathbf{P}$ & BP & 0.1 & 0 & 0 & 0 \\
\hline SD & $\mathbf{P}$ & $\mathbf{P}$ & BP & 0.1 & 0 & 0 & 0 \\
\hline SD & $\mathbf{P}$ & $\mathbf{P}$ & BP & 0.1 & 0 & 0 & 0 \\
\hline CLSD & $P$ & $\mathbf{P}$ & BP & 0.1 & 0 & 0 & 0 \\
\hline CLSD & $\mathbf{P}$ & $P$ & BP & 0.1 & 0 & 0 & 0 \\
\hline CLSD & $\mathbf{P}$ & $\mathbf{P}$ & BP & 0.1 & 0 & 0 & 0 \\
\hline CLSD & $\boldsymbol{P}$ & $P$ & BP & 0.1 & 0 & 0 & 0 \\
\hline
\end{tabular}


REA NO SCR DEPTH REC IND COLOR STRUCTUR \%GR \%SD \%MD MX MD B \%CG \%CS \%CM \%CMT \%CAR NAME SO \%POR TYPE \%MUS \%GLA \%LIG \%SUL H EOSSILS

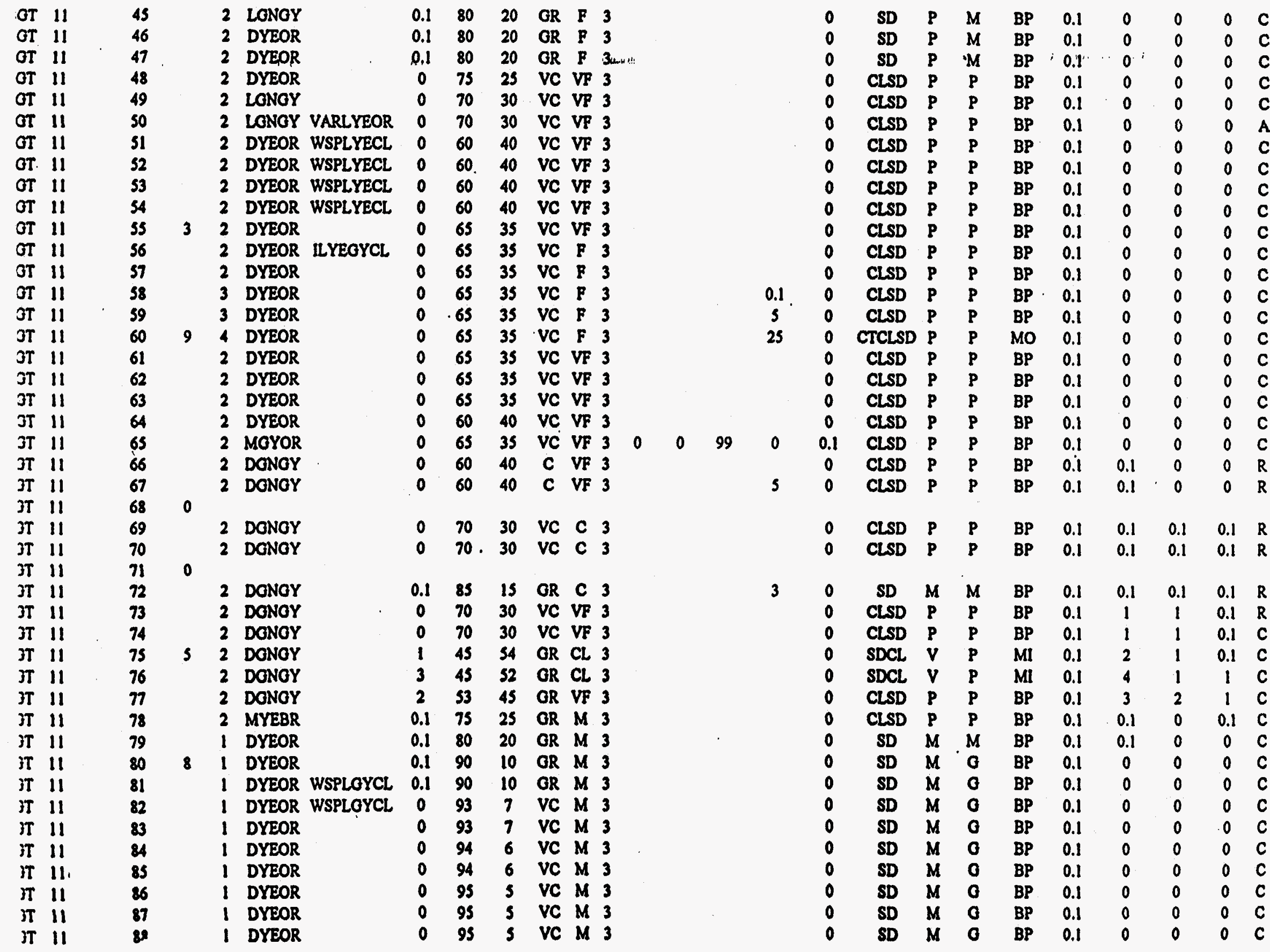




\section{IA NO SCR DEPTH REC IND COLOBSTRUCTUR \%GR \%SD \%MD MX MD B \%CG \%CS \%CM \%CMT \%CAR $\triangle A M E$ SO \%POR TYPE \%MUS \%GLA \%LIG \%SUL H EOSSILS}

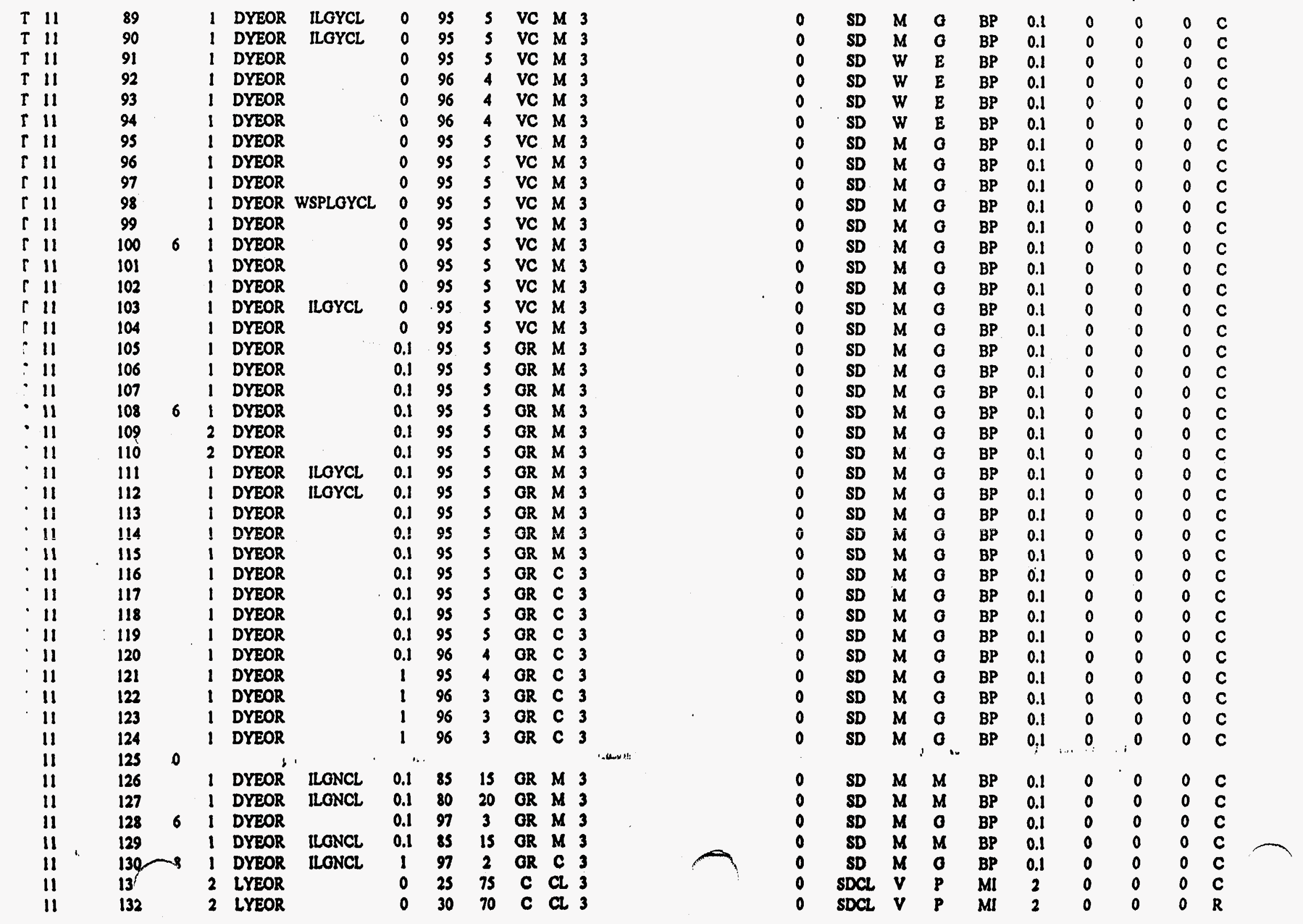




\section{BEA NQ SCR DEPTH REC IND COLORSTRUCTUR \%GR \%SD \%MD MX MD B \%CG \%CS \%CM \%CMT \%CAR NAME SO \%POR TYPE \%MUS \%GLA \%LIG \%SUL H FOSSILS}

\begin{tabular}{|c|c|c|c|c|c|c|c|c|c|c|}
\hline $39 T$ & 133 & & 2 & LYEOR & & 0 & 40 & 60 & c & $\mathrm{CL}$ \\
\hline $3 G T \quad 11$ & 134 & & 2 & LYEOR & & 0 & 70 & 30 & C & $\mathbf{F}$ \\
\hline $3 G T 11$ & 135 & & 2 & LYEOR & & 0 & 75 & 25 & C & $\mathbf{F}$ \\
\hline $30 \mathrm{~T} \quad 11$ & 136 & & 2 & LYEOR & & 0.1 & 80 & 20 & GR & $\mathbf{M}$ \\
\hline $30 T$ & 137 & & 2 & LYEOR & & 0.1 & 80 & 20 & GR & $\mathbf{M}$ \\
\hline SOT & 138 & & 2 & LYEOR & & 0.1 & 85 & 15 & GR & $\mathbf{M}$ \\
\hline $30 T$ & 139 & & 2 & LYEOR & & 0.1 & 85 & 15 & GR & $\mathbf{M}$ \\
\hline IOT & 140 & & 2 & LYEOR & & 0.1 & 85 & 15 & GR & $M$ \\
\hline $30 T$ & 141 & & 2 & LYEOR & & 0.1 & 90 & 10 & GR & $\mathbf{M}$ \\
\hline 30T & 142 & & 2 & LYEOR & & 0.1 & 90 & 10 & GR & $\mathbf{M}$ \\
\hline IOT & 143 & & 2 & LYEOR & & 0.1 & 90 & 10 & GR & $\mathbf{M}$ \\
\hline IOT & 144 & & 2 & LYEOR & & 0.1 & 90 & 10 & GR & $\mathbf{M}$ \\
\hline IOT & 145 & & 2 & LYEOR & & 0.1 & 90 & 10 & GR & $\mathbf{M}$ \\
\hline IOT & 146 & & 2 & LYEOR & & 0.1 & 90 & 10 & $G R$ & $\mathbf{M}$ \\
\hline IOT & 147 & & 2 & LYEOR & & 0.1 & 90 & 10 & GR & $\mathbf{M}$ \\
\hline IGT & 148 & & 2 & LYEOR & & 0.1 & 90 & 10 & GR & $M$ \\
\hline GT & 149 & & 2 & LYEOR & & 0.1 & 90 & 10 & $\mathrm{GR}$ & $\mathbf{M}$ \\
\hline IOT & 150 & & 2 & LYEOR & & 0.1 & 90 & 10 & GR & $\mathbf{M}$ \\
\hline IOT & 151 & & 2 & MYEBR & LOYCLB & 1 & 94 & $s$ & LP & C \\
\hline IOT & 152 & & 2 & MYEBR & LOYCLB & 3 & 90 & 5 & LP & ve \\
\hline $10 T$ & 153 & & 2 & MYEBR & LOYCLB & 10 & 85 & 5 & LP & ve \\
\hline IOT & 154 & & 2 & MYEBR & LOYCLB & 10 & 85 & 3 & LP & vc \\
\hline IOT & 155 & & 2 & MYEBR & LOYCLB & 25 & 70 & $s$ & LP & ve \\
\hline OT & 156 & & 2 & MBROY & & 0 & 1 & 99 & $\mathbf{M}$ & $\mathrm{CL}$ \\
\hline OT & 157 & & 2 & LOY & & 0 & 1 & 99 & $M$ & CL \\
\hline$G T$ & 158 & & 2 & LOY & & 0 & 2 & 98 & $M$ & CL \\
\hline OT & 159 & & 2 & MOY & IDOYCL & 0 & 40 & 60 & ve & $\mathbf{F}$ \\
\hline OT & 160 & & 2 & MOY & & 0 & 80 & 20 & VC & $\mathbf{M}$ \\
\hline OT & 161 & & 2 & MOY & & 0 & 80 & 20 & ve & $M$ \\
\hline :OT & 162 & & 2 & MOY & & 0 & 80 & 20 & ve & $M$ \\
\hline IOT & 163 & & 2 & MOY & & 0 & 80 & 20 & ve & $\mathbf{M}$ \\
\hline ior & 164 & & 2 & MOY & & 0 & 75 & 25 & ve & F \\
\hline ior & 165 & & 2 & MOY & & 0 & 75 & 25 & ve & $\mathbf{F}$ \\
\hline OT & 166 & & 2 & MGY & & 0 & 65 & 35 & Vc & $F$ \\
\hline :OT & 167 & & 2 & MOY & & 0 & 65 & 35 & ve & F \\
\hline GT & 168 & 9 & 2 & MOY & & 0 & 65 & 35 & ve & F \\
\hline GT & 169 & & 2 & MOY & $\cdot$ & 0 & 65 & 35 & ve & $\mathbf{F}$ \\
\hline OT & 170 & & 2 & MGY & & 0 & 60 & 40 & Vc & $\mathbf{F}$ \\
\hline OT & 171 & & 2 & MOY & & 0 & 30 & 70 & c & CL \\
\hline OT & 172 & & 2 & MOY & & 0 & 30 & 70 & C & $C L$ \\
\hline OT & 173 & & 2 & MOY & & 0 & 25 & 75 & c & CL \\
\hline or & 174 & & 2 & MOY & & 0 & 25 & 75 & C & CL. \\
\hline or 11 & 175 & & 2 & MOY & & 0 & 25 & 75 & C & CL. \\
\hline or 11 & 190 & & 2 & DOY & & 0 & 5 & 95 & C & CL \\
\hline
\end{tabular}

\begin{tabular}{|c|c|c|c|c|c|c|c|}
\hline SDCL & V & $P$ & MI & 2 & 0 & 0 & 0 \\
\hline CLSD & $P$ & $\mathbf{P}$ & BP & 1 & 0 & 0 & 0 \\
\hline CLSD & $p$ & P & $\mathrm{BP}$ & 1 & 0 & 0 & 0 \\
\hline SD & $\mathbf{M}$ & $\mathbf{M}$ & BP & 1 & 0 & 0 & 0 \\
\hline SD & $\mathbf{M}$ & $\mathcal{M}$ & BP & 1 & 0 & 0 & 0 \\
\hline SD & $\mathbf{M}$ & $\mathbf{M}$ & BP & 1 & 0 & 0 & 0 \\
\hline SD & $M$ & $\mathbf{M}$ & BP & 1 & 0 & 0 & 0 \\
\hline SD & $\mathbf{M}$ & $M$ & BP & 1 & 0 & 0 & 0 \\
\hline SD & $M$ & $\mathbf{M}$ & $\mathrm{BP}$ & 2 & 0 & $c$ & 0 \\
\hline SD & $M$ & $\mathbf{M}$ & $\mathrm{BP}$ & 1 & 0 & 0 & 0 \\
\hline SD & $M$ & $\mathbf{M}$ & $\mathrm{BP}$ & 1 & 0 & 0 & 0 \\
\hline SD & $\mathbf{M}$ & $\mathbf{M}$ & BP & 1 & 0 & 0 & 0 \\
\hline$S D$ & $M$ & $\mathbf{M}$ & BP & 1 & 0 & 0 & 0 \\
\hline SD & $\mathbf{M}$ & $M$ & BP & 1 & 0 & 0 & 0 \\
\hline$S D$ & $\mathbf{M}$ & $M$ & BP & 1 & 0 & 0 & 0 \\
\hline SD & $M$ & $\mathbf{M}$ & BP & 1 & 0 & 0 & 0 \\
\hline SD & $M$ & $\mathbf{M}$ & BP & 1 & 0 & 0 & 0 \\
\hline SD & $\mathbf{M}$ & $M$ & BP & 1 & 0 & 0 & 0 \\
\hline SD & $\mathbf{P}$ & 0 & BP & 1 & 0 & 0 & 0 \\
\hline$S D$ & $P$ & 0 & BP & 1 & 0 & 0 & 0 \\
\hline$S D$ & $\mathbf{P}$ & 0 & BP & 1 & 0 & 0 & 0 \\
\hline SD & $\mathbf{P}$ & 0 & BP & 1 & 0 & 0 & 0 \\
\hline PBSD & $P$ & 0 & BP & 1 & 0 & 0 & 0 \\
\hline $\mathrm{CL}$ & $\mathbf{v}$ & $\mathbf{P}$ & $\mathrm{MI}$ & 0.1 & 0 & 0.1 & 0 \\
\hline CL & $v$ & $\mathbf{P}$ & MI & 0.1 & 0 & 0.1 & 0 \\
\hline $\mathrm{CL}$ & $V$ & $\mathbf{P}$ & MI & 0.1 & 0 & 0.1 & 0.1 \\
\hline SDCL & $\mathbf{V}$ & $\mathbf{P}$ & MI & 0.1 & 0 & 0.1 & 1 \\
\hline SD & $M$ & $\mathbf{M}$ & BP & 0.1 & 0 & 1 & 0.1 \\
\hline SD & $M$ & $\mathbf{M}$ & BP & 0.1 & 0 & 0.1 & 0.1 \\
\hline$S D$ & $M$ & $\mathbf{M}$ & BP & 0.1 & 0 & 0.1 & 0.1 \\
\hline SD & $\mathbf{M}$ & $M$ & BP & 0.1 & 0 & 0.1 & 0.1 \\
\hline CLSD & $P$ & $P$ & BP & 0.1 & 0 & 1 & 0.1 \\
\hline CLSD & $P$ & $\mathbf{P}$ & $\mathrm{BP}$ & 0.1 & 0 & 1 & 0.1 \\
\hline CLSD & P & $P$ & BP & 0.1 & 0 & 1 & 0.1 \\
\hline CLSD & $P$ & $\mathbf{P}$ & BP & 0.1 & 0 & 1 & 0.1 \\
\hline CLSD & $\mathbf{P}$ & $P$ & BP & 0.1 & 0 & 1 & 0.1 \\
\hline CLSD & P & $P$ & BP & 0.1 & 0 & 1 & 0.1 \\
\hline CLSD & $P$ & $\mathbf{P}$ & $B P$ & 0.1 & 0 & 1 & 0.1 \\
\hline SDCL & $\mathbf{V}$ & $\mathbf{P}$ & MI & 0.1 & 0 & 1 & 0.1 \\
\hline SDCL & $\mathbf{V}$ & $P$ & MI & 0.1 & 0 & 2 & 0.1 \\
\hline SDCL & $V$ & $\mathbf{P}$ & MI & 0.1 & 0 & 2 & 0.1 \\
\hline SDCl & $\mathbf{V}$ & $\mathbf{P}$ & MI & 0.1 & 0 & 2 & 0.1 \\
\hline SDCL & $\mathbf{V}$ & $P$ & MI & 0.1 & 0 & 1 & 0.1 \\
\hline ct & $v$ & $\mathbf{P}$ & MI & 0.1 & 0 & 1 & 0.1 \\
\hline
\end{tabular}




$$
\text { BGT-1ISB COR RIPTION }
$$

EA NO SCR DEPTH REC IND COLOR STRUCTUR \%GR \%SD \%MD MX MD B \%CG \%CS \%CM \%CMT \%CAR NAME SO \%POR TYPE \%MUS \%GLA \%LIG \%SUL H EOSSILS

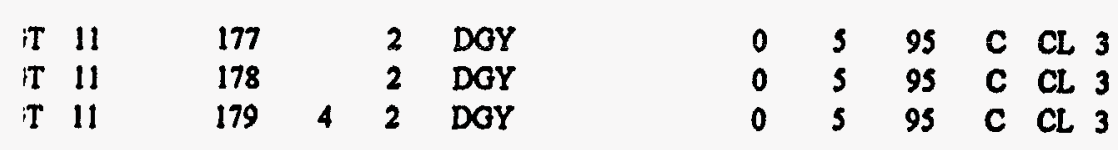

$\begin{array}{lllllllll}\text { CL } & \mathbf{V} & \mathbf{P} & \mathrm{MI} & 0.1 & 0 & 1 & 0.1 & \mathrm{R} \\ \mathrm{CL} & \mathrm{V} & \mathbf{P} & \mathrm{MI} & 0.1 & 0 & 1 & 0.1 & \mathrm{R}\end{array}$

$\begin{array}{lllllllll}C L & V & P & \text { MI } & 0.1 & 0 & 1 & 0.1 & R\end{array}$ 


\section{GR A IES \\ ENVIRONMENTAL \& GEOTECHNICAL \\ SERVICES}

\section{$\mathrm{BGT}-20$}

$\begin{array}{ll}\text { MPAHY } & \text { : EMTC } \\ L L & : B G T-20\end{array}$

CATION/FIELO : BURIAL GROUND COMPLEX SRS

UNTY

ATE

: AIKEN

CTION

: $S C$

TE

: 12/08/94 PERMANENT DATUM : -

PTH DRILLER : 110

G BOTTOM

G TOP

$: \quad 109.10$

ELEU. PERM. DATUM:

LOG MEASURED FROM: GL

DRL MEASURED FROM: -

OTHER SERUICES:

$-.21$

LOGGING UNIT

: 426

FIELD OFFICE

: JACKSON

RECORDED BY

: ROOKS

T SIZE

: 5

GNETIC DECL. : -

BOREHOLE FLUID: MUD/H2O

FILE : PROCESSED

RM

$:-$

TYPE : $9041 \mathrm{~A}$

RM TEMPERATURE : -

LOG : 5

MATRIX DELTA T : -

PLOT : 44440

UID DENSITY : -

FLUID DELTA T : -

THRESH: 50000 

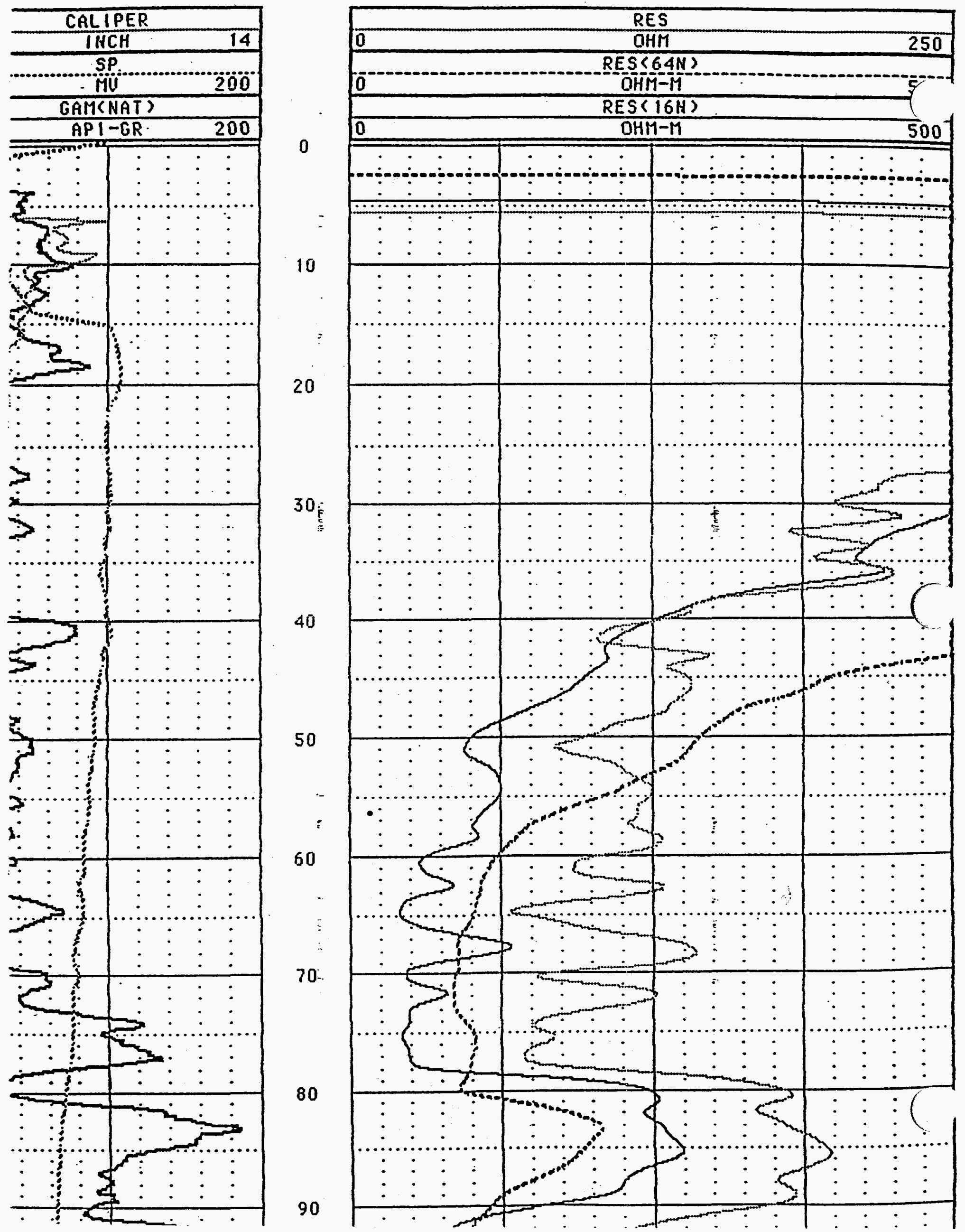

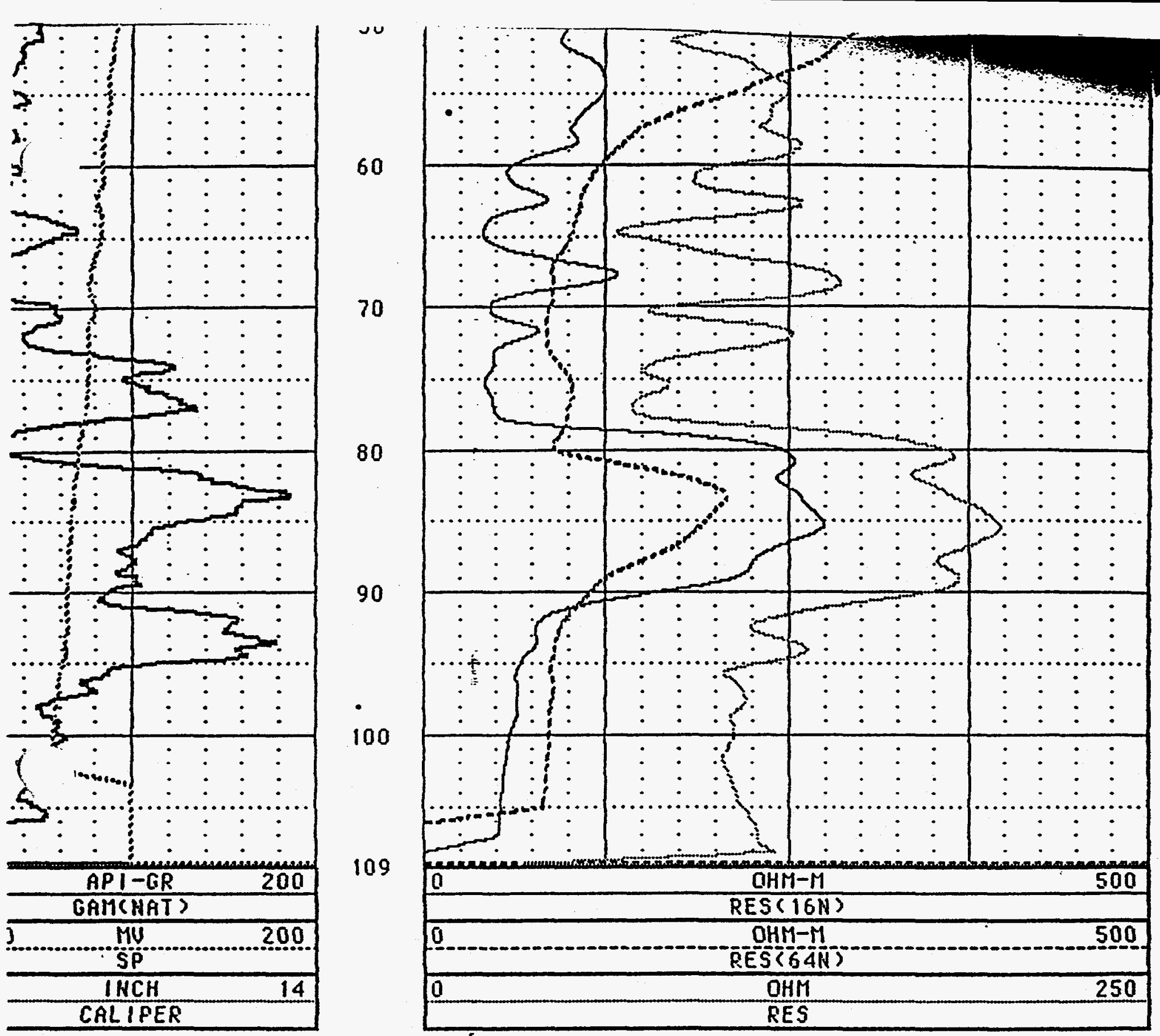

BGT-20 12/08/94 263 
RE NO SCR DEPT REC IND COLOR STRUCTURE GR \%SD \%MD MX MD B \%CG \%CS\%CM CMT CAB NAME SO \%POR TYP \%MUS \%GLA \%LIG \%SUL H EOSSILS

10

(

0

0

0

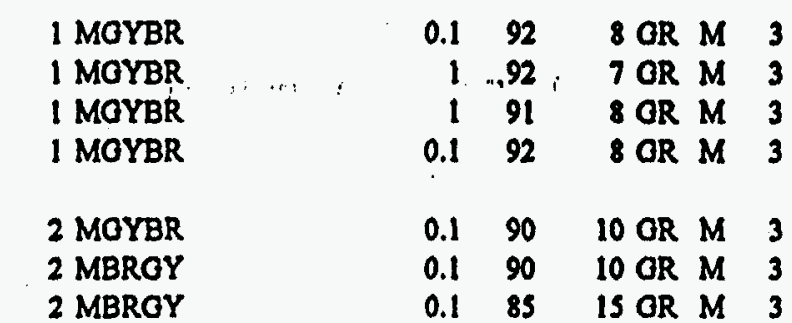

0

0

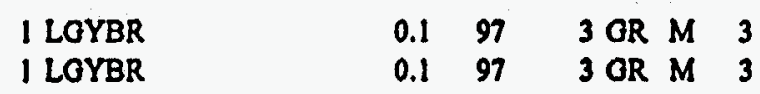

4 I LOYBR

0.1973 OR $M \quad 3$

$\begin{array}{lllll}1 \text { MOY } & 0.1 & 97 & 3 \text { OR } & M\end{array}$

1 LBROY $\quad 295$ 3 OR M 3

5 I LBROY

1963 OR $M \quad 3$

I DYEOR WSPLONCL 0.1 95 5 GR M 3

1 DYEOR WSPLONCL 0.1 95 S OR M 3

6 I MOYOR

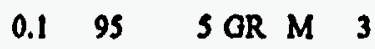

1 MOYOR ICTSD $\quad 0.1$ 95 SOR M 3

$\begin{array}{lllllll}1 & \text { MOYOR ICTSDICL } & 0.1 & 80 & 20 \mathrm{OR} & \mathrm{M} & 3\end{array}$

MONOY

2 MONOY

$1 \mathrm{MOY}$

$6 \quad 1$ MOY $\begin{array}{lcccc}0 & 5 & 95 \mathrm{C} & \mathrm{CL} & 3 \\ 0 & 2 & 98 \mathrm{C} & \mathrm{CL} & 3 \\ 0 & 93 & 7 \mathrm{VC} & \mathrm{M} & 3\end{array}$

$0 \quad 94 \quad 6$ VC $M$

\begin{tabular}{|c|c|c|c|c|c|c|c|c|}
\hline \multirow{7}{*}{; } & 0 SD & $\mathbf{M}$ & 0 & BP & 0.1 & 0 & 0.1 & $O R$ \\
\hline & 0 SD & $M$ & O & $\mathbf{B P}$ & 0.1 & 0 & 0.1 & $O R$ \\
\hline & 0 SD & $\mathbf{M}$ & 0 & BP & 0.1 & 0 & 0.1 & OR \\
\hline & 0 SD & $M$ & 0 & BP & 0.1 & 0 & 0.1 & $0 \mathrm{R}$ \\
\hline & 0 SD & $M$ & $M$ & BP & 0.1 & 0 & 2 & O R \\
\hline & 0 SD & $M$ & $M$ & BP & 0.1 & 0 & 0.1 & $O R$ \\
\hline & 0 SD & $\mathbf{M}$ & $\mathbf{M}$ & BP & 0.1 & 0 & 0.1 & $O R$ \\
\hline & 0 SD & $W$ & $E$ & BP & 0.1 & 0 & 0 & $O C$ \\
\hline & O SD & W & E & BP & 0.1 & 0 & 0 & OR \\
\hline & 0 SD & $\mathbf{W}$ & $\mathbf{E}$ & $\mathrm{BP}$ & 0.1 & 0 & 0 & $O C$ \\
\hline & 0 SD & W & E & BP & 0.1 & 0 & 0 & $0 R$ \\
\hline & O SD & $M$ & $\mathbf{E}$ & $\mathrm{BP}$ & 0.1 & 0 & 0 & OR \\
\hline & 0 SD & $M$ & $\mathbf{E}$ & $\mathrm{BP}$ & 0.1 & 0 & 0 & $O R$ \\
\hline & 0 SD & $\mathbf{M}$ & 0 & BP & 0.1 & 0 & 0 & OR \\
\hline & 0 SD & $M$ & 0 & BP & 0.1 & 0 & 0 & $O R$ \\
\hline & 0 SD & $M$ & 0 & BP & 0.1 & 0 & 0 & OR \\
\hline 0.1 & 0 SD & $\mathbf{M}$ & $\mathbf{G}$ & $\mathrm{BP}$ & 0.1 & 0 & 0 & O R \\
\hline 0.1 & $0 \mathrm{SD}$ & $\mathbf{M}$ & $\mathbf{M}$ & BP & 0.1 & 0 & 0 & O R \\
\hline
\end{tabular}

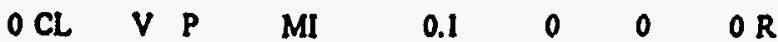

$\begin{array}{llllllll}O C L & V & P & M I & 0.1 & 0 & 0 & 0 R\end{array}$

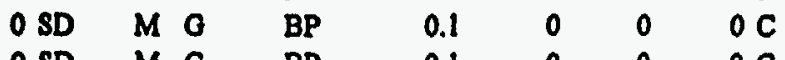

O SD M G

Page 10. 
ARE NO SCR DEPT REC IND COLOR STRUCTURE GR \%SD \%MD MX MD B \%CG \%CS \%CM CMT CAR NAME SQ \%POR TYP \%MUS \%GLA \%LIG \%SUL H FOSSILS .

\begin{tabular}{|c|c|}
\hline & 2 \\
\hline $30 \mathrm{~T}$ & 2 \\
\hline $30 T$ & 2 \\
\hline $30 T$ & 2 \\
\hline $30 T$ & 20 \\
\hline IOT & 20 \\
\hline IGT & 20 \\
\hline :OT & 20 \\
\hline OT & 20 \\
\hline OT & 20 \\
\hline OT & 20 \\
\hline OT & 20 \\
\hline OT & 20 \\
\hline OT & 20 \\
\hline OT & 20 \\
\hline OT & 20 \\
\hline ot & 20 \\
\hline OT & 20 \\
\hline $3 T$ & 20 \\
\hline JT & 20 \\
\hline $3 T$ & 20 \\
\hline $3 T$ & 20 \\
\hline $3 T$ & 20 \\
\hline $3 T$ & 20 \\
\hline $3 T$ & 20 \\
\hline $3 T$ & 20 \\
\hline $3 T$ & 20 \\
\hline IT & 20 \\
\hline $3 T$ & 20 \\
\hline $3 T$ & 20 \\
\hline $3 T$ & 20 \\
\hline $3 T$ & 20 \\
\hline iT & 20 \\
\hline iT & 20 \\
\hline iT & 20 \\
\hline IT & 20 \\
\hline $\mathrm{iT}$ & 20 \\
\hline $\mathrm{IT}$ & 20 \\
\hline $\mathbf{T}$ & 20 \\
\hline $\mathbf{T}$ & 20 \\
\hline $\mathbf{T}$ & 20 \\
\hline $\mathrm{IT}$ & 20 \\
\hline $\mathrm{IT}$ & 2 \\
\hline IT & \\
\hline
\end{tabular}

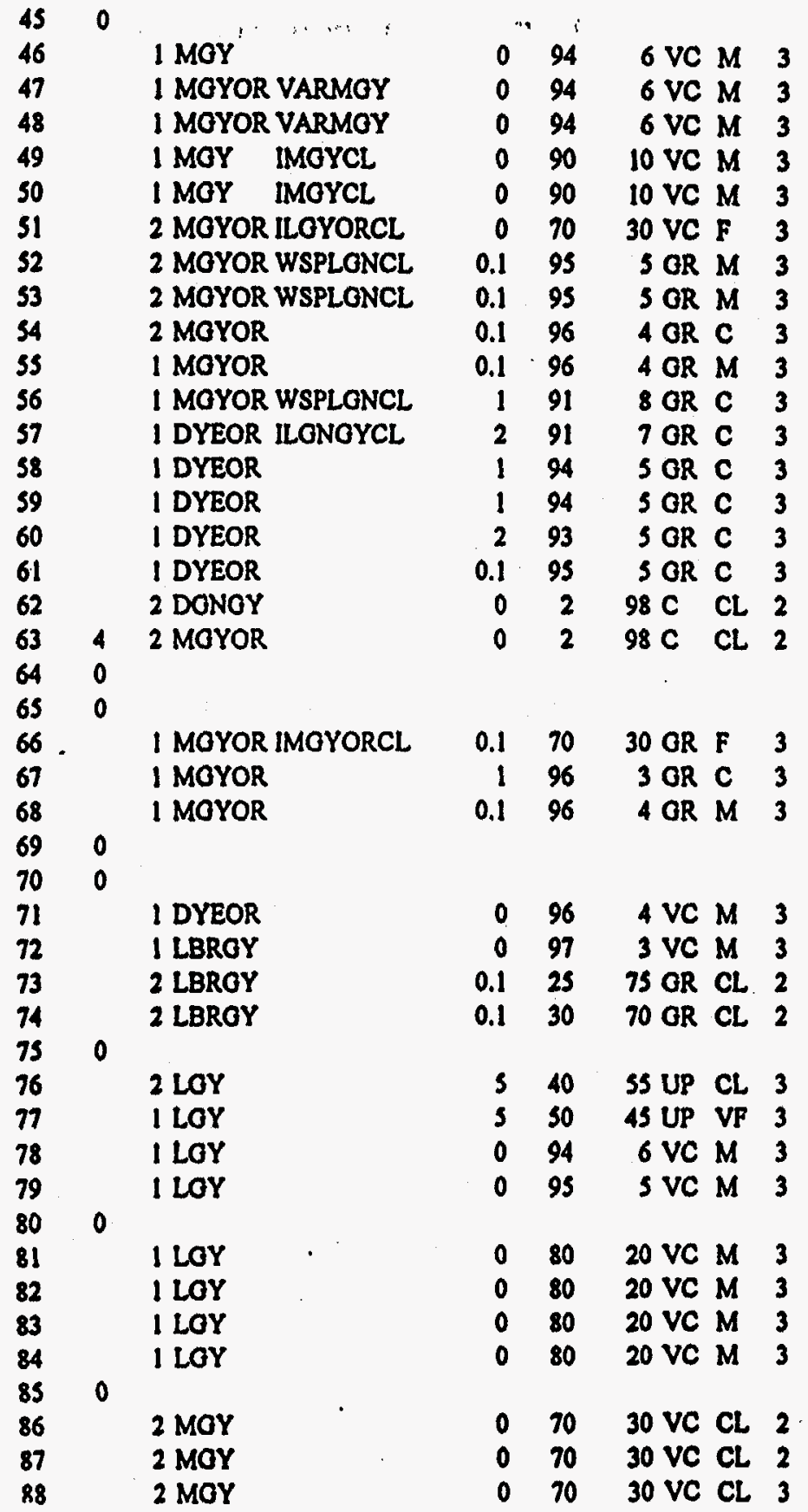

\begin{tabular}{|c|c|c|c|c|c|c|c|}
\hline 0 SD & $M$ & 0 & BP & 0.1 & 0 & 0 & $0 \mathrm{C}$ \\
\hline $0 \mathrm{SD}$ & $\mathbf{M}$ & 0 & BP & 0.1 & 0 & 0 & OC \\
\hline 0 SD & $M$ & 0 & BP & 0.1 & 0 & 0 & OC \\
\hline $0 \mathrm{SD}$ & $M$ & $M$ & BP & 0.1 & 0 & 0 & OC \\
\hline O SD & M & $M$ & $\mathrm{BP}$ & 0.1 & 0 & 0 & OC \\
\hline 0 CLSD & $\mathbf{P}$ & $P$ & $\mathrm{BP}$ & 0.1 & 0 & 0 & $0 \mathrm{C}$ \\
\hline 0 SD & $\mathbf{M}$ & 0 & BP & 0.1 & 0 & 0 & $O C$ \\
\hline 0 SD & $\mathbf{M}$ & 0 & $\mathrm{BP}$ & 0.1 & 0 & 0 & $0 \mathrm{C}$ \\
\hline $0 \mathrm{SD}$ & $M$ & 0 & $B P$ & 0.1 & 0 & 0 & $0 \mathrm{C}$ \\
\hline $0 \mathrm{SD}$ & $\mathbf{M}$ & 0 & BP & 0.1 & 0 & 0 & OC \\
\hline $0 \mathrm{SD}$ & $\mathbf{M}$ & 0 & BP & 0.1 & 0 & 0 & $0 \mathrm{C}$ \\
\hline $0 \mathrm{SD}$ & $M$ & 0 & BP & 0.1 & 0 & 0 & $0 \mathrm{C}$ \\
\hline $0 \mathrm{SD}$ & $\mathbf{M}$ & 0 & $\mathrm{BP}$ & 0.1 & 0 & 0 & O C \\
\hline $0 \mathrm{SD}$ & $\mathbf{M}$ & 0 & $\mathrm{BP}$ & 0.1 & 0 & 0 & OC \\
\hline $0 \mathrm{SD}$ & $M$ & 0 & $B P$ & 0.1 & 0 & 0 & OC \\
\hline $0 \mathrm{SD}$ & $\mathbf{M}$ & 0 & BP & 0.1 & 0 & 0 & $0 \mathrm{C}$ \\
\hline $0 \mathrm{CL}$ & $\mathbf{V}$ & $\mathbf{P}$ & MI & 0.1 & 0 & 0 & $O R$ \\
\hline $0 \mathrm{CL}$ & V & $\mathbf{P}$ & $M I$ & 0.1 & 0 & 0 & OR \\
\hline
\end{tabular}

0 CLSD P P BP $O S D \quad M O \quad B P$

$O S D \quad M O \quad B P$

O SD $M O \quad B P$ O SD M O BP O SDCL V P $O$ SDCL V $P$

O SDCL V P O CLSD P P $O S D \quad M O \quad B P$

O SD $M O \quad B P$

O SD $M M \quad B P$

O SD $M M \quad B P$

SD $M M \quad B P$

O CLSD P P BP $O$ CLSD P P BP 0 CLSD P P BP
$O S D \quad M M \quad B P$

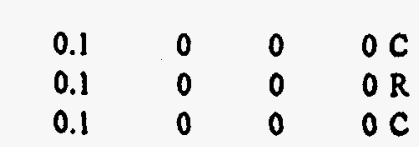

$$
\begin{array}{llll}
0.1 & 0 & 0 & 0 \mathrm{C} \\
0.1 & 0 & 0 & 0 \mathrm{C} \\
0.1 & 0 & 0 & 0 \mathrm{R} \\
0.1 & 0 & 0 & 0 \mathrm{R}
\end{array}
$$

$$
\begin{array}{rrrr}
0.1 & 0 & 0.1 & 0.1 R \\
0.1 & 0 & 0.1 & 0.1 \mathrm{R} \\
1 & 0 & 0 & 2 \mathrm{C} \\
1 & 0 & 0.1 & 2 \mathrm{C}
\end{array}
$$


BGT-20SB CO: $\quad$ :RIPTION

IE NO SCR DEPT REC IND COLOR STRUCTURE

GB \%SD \%MD MX MD B \%CG \%CS \%CM CMT CAR NAME SO \%POR TYP \%MUS \%GLA \%IJG \%SUL H EOSSILS

$\begin{array}{ll}\text { IT } & 20 \\ \text { IT } & 20 \\ T T & 20 \\ T T & 20 \\ T & 20 \\ T & 20 \\ T & 20 \\ T & 20 \\ T & 20 \\ T & 20 \\ T & 20 \\ T & 20 \\ T & 20 \\ T & 20 \\ i & 20 \\ i & 20 \\ i & 20 \\ i & 20 \\ . & 20 \\ . & 20 \\ . & 20 \\ . & 20\end{array}$

\begin{tabular}{|c|c|c|c|}
\hline 89 & & $2 \mathrm{MOY}$ & \\
\hline 90 & & $2 \mathrm{MOY}$ & \\
\hline 91 & & 2 DOY & WSPLOYSD \\
\hline 92 & • & 2 DOY & WSPLOYSD \\
\hline 93 & & 2 DOY & \\
\hline 94 & & 2 DGY & \\
\hline 95 & & 2 DOY & \\
\hline 96 & & 2 DOY & \\
\hline 97 & & 2 DOY & \\
\hline 98 & & $2 \mathrm{DOY}$ & \\
\hline 99 & & $2 \mathrm{DOY}$ & \\
\hline 100 & & 2 DOY & \\
\hline 101 & 4 & 2 DGNOY & \\
\hline 102 & & 2 DONOY & \\
\hline 103 & & 2 DONOY & \\
\hline 104 & & 2 DONOY & \\
\hline 105 & & 2 DONOY & \\
\hline 106 & & 2 DONOY & \\
\hline 107 & & 2 DONOY & \\
\hline 108 & & 2 DONOY & \\
\hline 109 & & 2 DONOY & \\
\hline 110 & & 2 DONOY & \\
\hline
\end{tabular}

$07525 \mathrm{VC}$ CL 3

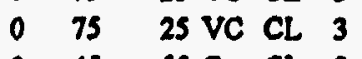

$\begin{array}{lllll}0 & 45 & 55 \mathrm{C} & \mathrm{CL} & 2\end{array}$

$\begin{array}{lllll}0 & 35 & 65 \mathrm{C} & \mathrm{CL} & 2\end{array}$

$\begin{array}{lllll}0 & 35 & 65 \mathrm{C} & \mathrm{CL} & 2\end{array}$

$0 \quad 3070 \mathrm{C} \quad \mathrm{CL} 2$

- $20 \quad 80 \mathrm{C} \quad \mathrm{CL} 2$

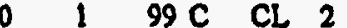

$\begin{array}{llllll}0 & 0.1 & 99 \mathrm{C} & \mathrm{CL} & 2\end{array}$

$\begin{array}{llllll}0 & 0.1 & 99 & \mathrm{C} & \mathrm{CL} & 2\end{array}$

$\begin{array}{lllll}0 & 1 & 99 \mathrm{C} & \mathrm{CL} & 2\end{array}$

$\begin{array}{lllll}0 & 1 & 99 \mathrm{C} & \mathrm{CL} & 2\end{array}$

$0 \quad 199 \mathrm{C} \quad \mathrm{CL} 2$

$0 \quad 199 \mathrm{C} \quad \mathrm{CL} 2$

$\begin{array}{lllll}0 & 1 & 99 \mathrm{C} & \mathrm{CL} & 2\end{array}$

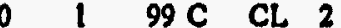

- $199 \mathrm{C} \quad \mathrm{CL} 2$

$\begin{array}{lllll} & 1 & 99 \mathrm{C} & \mathrm{CL} & 2\end{array}$

- $199 \mathrm{C} \quad \mathrm{CL} 2$

$\begin{array}{llllll}0 & 0.1 & 99 \mathrm{C} & \mathrm{CL} & 2\end{array}$

$\begin{array}{llllll}0 & 0.1 & 99 \mathrm{C} & \mathrm{CL} & 2\end{array}$

$\begin{array}{lllll}0 & 0.1 & 99 \mathrm{C} & \mathrm{CL} & 2\end{array}$

\begin{tabular}{|c|c|c|c|c|c|c|c|}
\hline 0 CLSD & $\mathbf{P}$ & $\mathbf{P}$ & BP & 2 & 0.1 & 0 & $0.1 \mathrm{R}$ \\
\hline 0 CLSD & $\mathbf{P}$ & $\mathbf{P}$ & $\mathrm{BP}$ & 2 & 0.1 & 0 & $0.1 \mathrm{R}$ \\
\hline 0 SDCL & V & P & Ml & 1 & 0.1 & 0 & $0.1 \mathrm{R}$ \\
\hline 0 SDCL. & $\mathbf{V}$ & $\mathbf{P}$ & MI & 1 & 0.1 & 0 & $0.1 R$ \\
\hline $0 \mathrm{SDCL}$ & V & $\mathbf{P}$ & $\mathrm{MI}$ & 1 & 0.1 & 0 & $0.1 \mathrm{R}$ \\
\hline 0 SDCL & V & $\mathbf{P}$ & $\mathrm{MI}$ & 1 & 0.1 & 0 & $0.1 \mathrm{R}$ \\
\hline $0 \mathrm{CL}$ & $\mathbf{V}$ & $\mathbf{P}$ & MI & 1 & 0.1 & 0 & $0.1 R$ \\
\hline$O \mathrm{CL}$ & V & $\mathbf{P}$ & $\mathrm{MI}$ & 1 & 0 & 0 & $2 R$ \\
\hline $0 \mathrm{CL}$ & V & $\mathbf{P}$ & $\mathrm{MI}$ & 1 & 0 & 0 & $2 R$ \\
\hline $0 \mathrm{CL}$ & $v$ & $\mathbf{p}$ & $\mathrm{MI}$ & 1 & 0 & 0 & $1 R$ \\
\hline $0 \mathrm{CL}$ & $\mathbf{V}$ & $\mathbf{P}$ & $\mathrm{MI}$ & 1 & 0 & 0 & I R \\
\hline $0 \mathrm{CL}$ & $\mathbf{V}$ & $\mathbf{P}$ & MI & 1 & 0 & 0 & $0.1 \mathrm{R}$ \\
\hline $0 \mathrm{CL}$ & V & $\mathbf{P}$ & $\mathrm{MI}$ & 1 & 0 & 0.1 & $0.1 \mathrm{R}$ \\
\hline $0 \mathrm{CL}$ & $\mathbf{V}$ & $\mathbf{p}$ & MI & 1 & 0 & 0.1 & $0.1 \mathrm{R}$ \\
\hline $0 \mathrm{CL}$ & $\mathbf{V}$ & $\mathbf{P}$ & $\mathrm{MI}$ & 1 & 0 & 0.1 & $0.1 \mathrm{R}$ \\
\hline$O \mathrm{CL}$ & V & P & M! & 1 & 0 & 0.1 & $0.1 R$ \\
\hline $0 \mathrm{CL}$ & V & $\mathbf{P}$ & MI & 1 & 0 & 0.1 & $0.1 R$ \\
\hline $0 \mathrm{CL}$ & V & $\mathbf{P}$ & MI & 1 & 0 & 0.1 & $0.1 R$ \\
\hline $0 \mathrm{CL}$ & V & $\mathbf{P}$ & MI & 1 & 0 & 0.1 & $0.1 R$ \\
\hline $0 \mathrm{CL}$ & V & $\mathbf{P}$ & $\mathrm{Ml}$ & 1 & 0 & 0.1 & $0.1 R$ \\
\hline $0 \mathrm{CL}$ & V & $\mathbf{P}$ & MI & 1 & 0 & 0.1 & $0.1 \mathrm{R}$ \\
\hline $0 \mathrm{CL}$ & $V$ & P & MI & 1 & 0 & 0.1 & $0.1 \mathrm{R}$ \\
\hline
\end{tabular}

